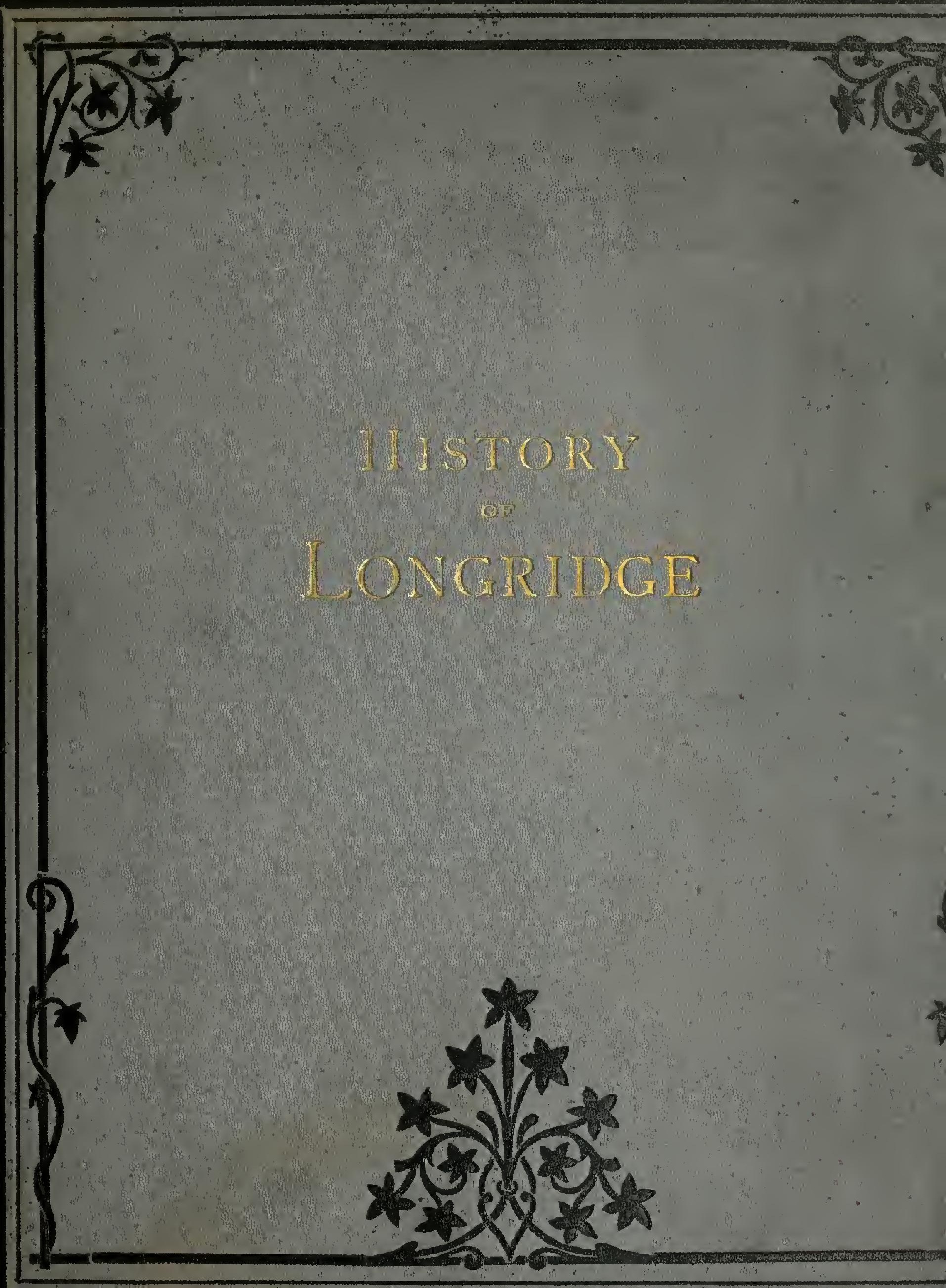




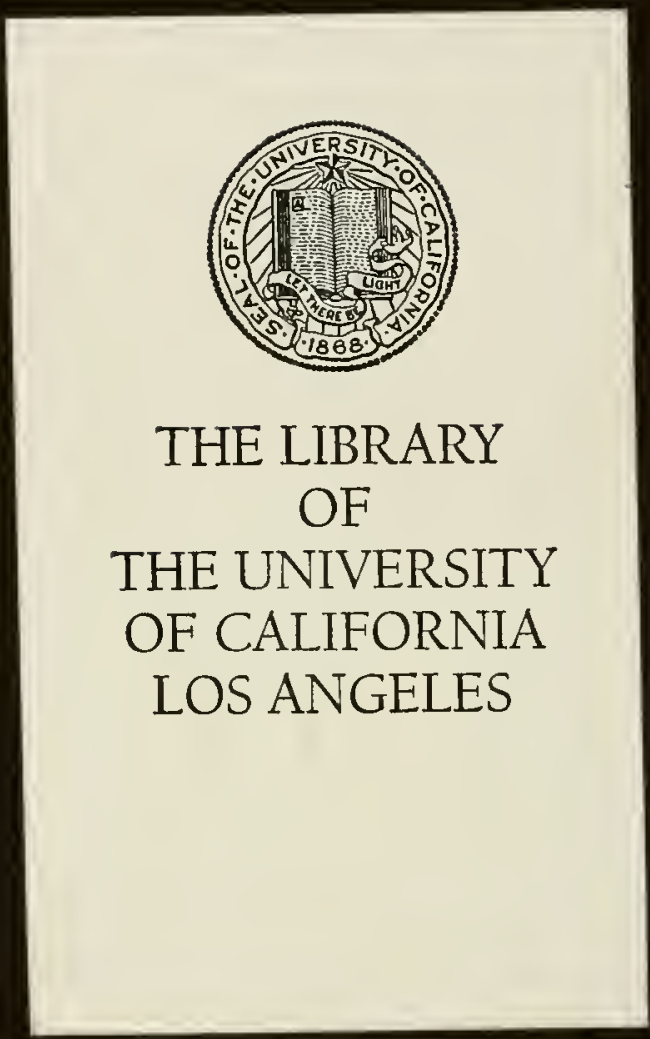




HISTORY OF LOAIRIDGE. 




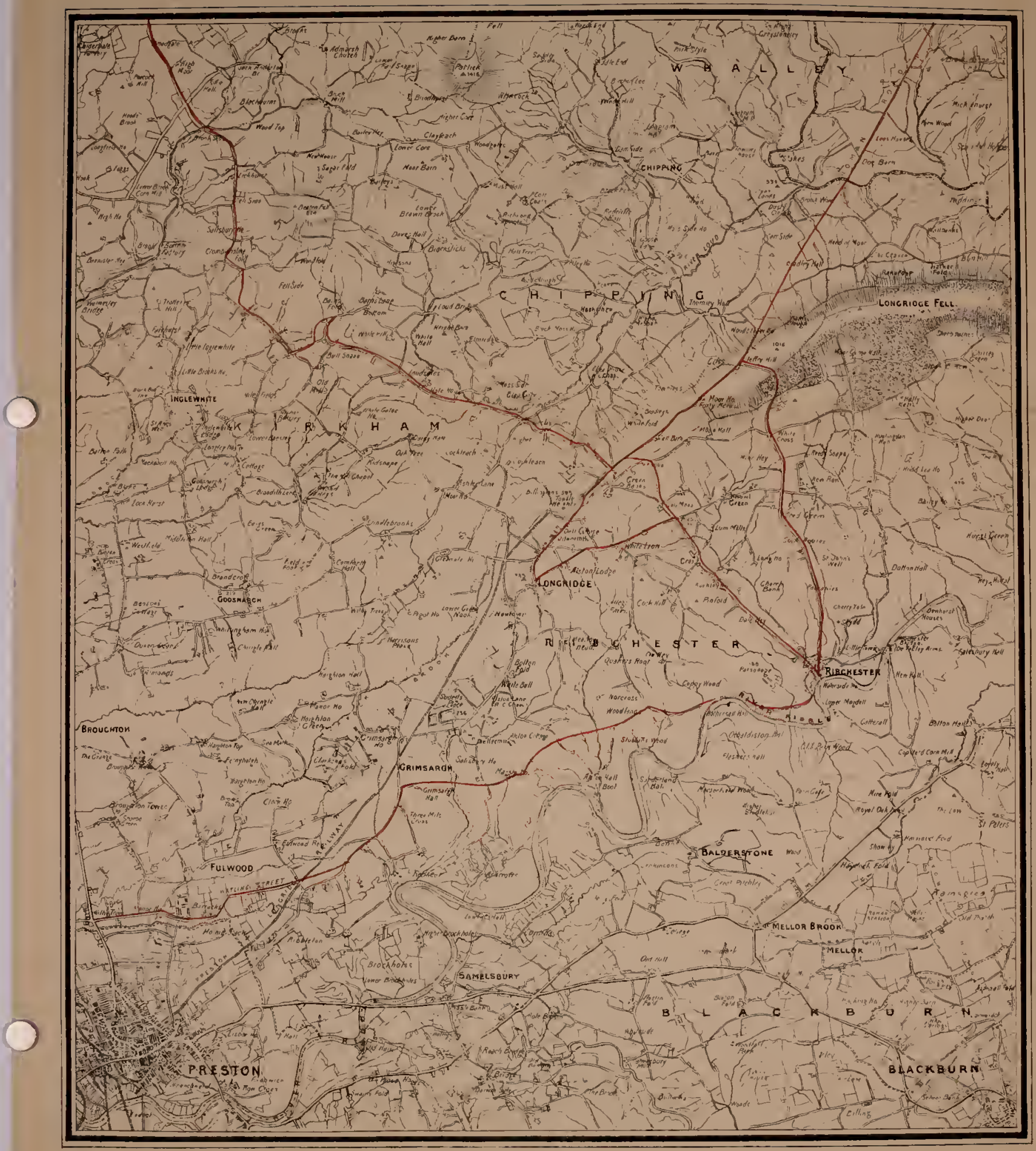




\section{HISTORY OF LONGRIDGE}

ANI)

\section{I S T R I C T.}

BY

TOM C. SMIIFE.

Since honour from the honourer proceeds, How well do they deserve, that memorize And leave in books for all posterities The names of worthies and their virtuous deeds; When all their glory else, like water-meeds Without their element, presently dies, And all their greatness quite forgotten lies, And when and how they flourished no man heeds!

-Florio.

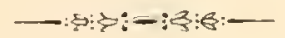

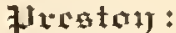

Printed bi (. W. Whithen, Fishelgate ani) Avenhas Street Mili. $1 \overline{1 s S S}$. 
西 


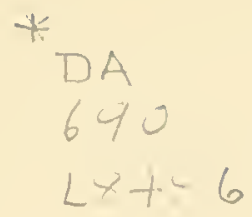

To

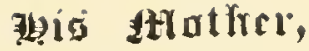

THE TENDER COUNSELIOR OF HIS YOU'TI,

As!

THE DEVOTED FRIEND OF HIS MANHOOD;

THIS BOOK

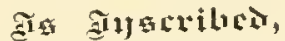

WITH FEELINGS OF 'THE TENDEREST LOVE AND RESPECT,

$\mathrm{BY}$

HER AFFECTIONATE SON,

(1) Euttlot. 


\section{ADDENDA ET CORRIGENDA.}

In spite of the greatest care and attention, the author has to apologise for the undermentioned clerical and typographical errors and omissions; the reacter is requested to make the alterations with his pen before perusing the book:-

Page 3, line 28.- "Vecinales" read ricinales.

, 31, "22.- "At" read al.

"38, , 10.- "John Stuart Mills" read John Stuart Mill.

" 43, , 32-34. - "1917" rend 1904; " 1904 " read 1821, a decrease of 83 ; "1821" read 1792 .

"47, , 22.- "Bred" restl fed.

" 44, , 20.- " Whittingham" read Whittington.

" 48, , 44. - " Reign" read reigus.

, 50, , 17.- " 1651 " read 1650 .

, 51, , 13.- "Extract" read extracts.

"52, , 33.- " 1759 " read 1679

"56, ," 6.-." "Willing" read willingly.

", 63, ,, 19.-Add who was incumbent of Rainforth Chapel, near Prescott, in 1650.

"63, , 6. - "Venesee" read Veeresee.

" 66, ," 21.- "Bradsha w" rend liainforth.

" 69, , 13. - "Vicarage" read, Vicar.

"166, ,2 26، - "Praemiseis" reud prremissis.

"169-Add the following uote:-In John Townley's will, dated 1562, Sir James Liungard is described as Vicar of Ribchester. He would sueceed Dr. Wolfytt, who ried in 1552-3. 


\section{ADVERTISEMENT.}

We question very much if any County has had more of its 1 istory written than the County Palatine of Lancaster. Lient.-Col. Fishwick, in his "Laneashirc Library," enumerates no fewer than 700 books dealing with the Ilistory of the County Palatine which had been written up to 1873 . It is, then, as a small contribution to the large and valuable Lancashire library that the Author has, by the favour and assistance of a generous public, hcen enabled to issue a History of Longridge and District. He ventures to think that he has scized a fitting opportunity, as the old order is fast chauging, and the memories of the past are fading away.

*. It is only due to the subscribers that the following explanation should be given of certain changes which the author has been compelled to make. Two views - "The Panoramic view of Longridge," and "Whittingham Asylum," promised in the prospectus are omitted (much to the author's regret), owing to unsurmountable difficulties. That the Subscribers havo not suffered is clear from the subjoined statement:- Thirty pages have been added to the work; the Illus. trations of the Processional Cross and Bishop's Chair, in the Catholic Church at Longridge, and of St. John's College, Grimsargh; a Sectional Plan of the District; two Plates of Geological and Botanical Specimens; and a Plate of the Cave. Browne-Cave Coat of Arms, have also bcen added. I ought not to omit my thanks to my publisher, who, under rather annoying circumstances, has turned out with such promptitude a work which, as regards print, paper, and binding, is a credit to the book trade of Preston.

\section{NOTICE.}

The Author begs to inform the public that a very limited number of copies of this work can be obtained on application to $\mathrm{Mr}$. Whitehead or himsclf. Prices: Small Copies, 7/6 ; Large Paper, 15/-. 


\section{INTRODUCTORY.}

ANYвом visiting Longridge for the first time readily discerns the philological

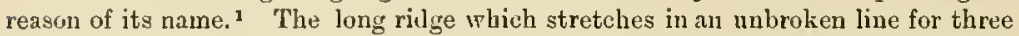
miles to Jeffrey Hill plainly has given birth to the nane of the town whose history I am about to describe. Indeed, rumour hath a very pretty and plansible tale anent this long ridge. It is said that Longridge owes its name to Oliver Cromwell, who, when on his way across the fells from Stonyhurst to Proston, said, "What a long ridge this is." But, pretty as this tale is, history compels us to relegate it to the lumber-room, to which are consigned so many similar romantic stories. For, as is shown in chapter II., mention is made in 1554-some hundred years befure Cromwell's time-of "Sir liobert Cutome, priest of Longryclie in Ribblechester."

Althongh giving its name to this book, it must be confessed that Longridge is noted not so much for its own history, or for what it contains in itself, but rather for the beautiful scenery, intiquarian history, and oljects of interest which abound in its immediate vicinity. Nevertheless, in spite of the somewhat uneagre history which attaches to it, I an sure that the gentle realer who accompanies me through the pages of this little work will be amply repaid for his trouble, and will therehy have arlied somewhat to his store of knowledye of this part of Lancashire. The writer claims no special qualifications for undertaling this task; indeed, he has keenly felt his many shorteomings, but, at any rate, be can say that he has carefully and faithfully rearl everything relating to the subject he conld possibly find; and that he has moreover brought to this labour - which has been truly a labour of love-an impartial, but an cnthusiastic mind withal.

"The various ways of spelling Ions ridge may be given here: Longerydche1554: Longruche-15i,4; Laniring1560; Lomg-ridge-1622; Lungridinc164s; Lamuryth $16-1698$.

Such authorities on the subject as $J$. C. Atkinson, and W. I1. Stevenson state that there is no seientifie treatise on the etymology of place names in the English language, and stronerly condemon the reckless practice of local histurians when dealiug with the orion of place names.

Mr. Stevensnn says: - "I)r. "laylur"s Fords and Plares aboumls in the grossest philoloricul error's, and in blunders that a little care woulil have obviaterl." And certainly he prover his sweeping assertion up to the very hilt.

I inust, therefore (having no pretensions whatever to philolngical learning), decline to commit myself as to the true orisin of the place names in this district, contenting myself with collecting all the early forms of the names of the tuwnships ant parisbes; and also giving the "Ilicta" of the two rival schools of philological thou, lit, leaving the rearler to draw bis own conclusions. 
He must, however, confess that the chapter on social and political events has cansed him most thought and anxiety. For, as is well known in the district -antl he has no desire to withhold the fact from his readers-the author has heen a strong, active, and is now a strong, passive, political partisan. Nore than onee he thonght that this fact would warrant him in omitting any reference to polities. In that case, the listory of Longridge would liave been far from complete. So, at last, gathering conrage from remembering that Mr. Justin MIc.Carthy's "History of Our Own Times "is not only one of the most readable bnt also one of the ruost impartial histories of recent years, althongh the historian himself had aken an active and learling part in many of the political events whose history he describes - he determined to do his best to be as impartial as possible. And I fail to see why a keen, political partisan should be incapahle of giving an historical account of what he himself has participated in, especially when we remember that no one is more likely than snch an one to be able to know more of the concealed springs which prompted certain movements-springs which would have been completely hidden from any non-politieian.

The task of writing this history has been considerably lightened by the valuable information which $I$ have obtaiued from the following works:-Baines's "Lancashire," Whittaker's "Whalley," Leigli's " Natural History of Lancashire," Watkin's " lioman Lancashire," Hardwick's " Preston," Fishwiek's "Goosnargh," Croston's "History of Samlesbury," Hewitson's "Our Country Churehes and Chapels," Gillow's "Haydock Papers," Canon Parkinson's "O] the Parish Registers of Pibchester Church, the varions publications of the Chetham Society and of the Record Society, Harland's "Legends" and "Folk. lore," Longworth's "Longrilge Almanack," "The Stonyhurst Magazine," the MS.. at the British Musenm and at the Record Otfice, E. Kirk's "Papers," Gillow's "Catholic Bibliographical Dictionary," "The Salford Catholic Almanack," etc., and various pamplilets, and articles in the Preston papers.

If anything conld have alded to the pleasure with which I have written this work, it wonld have been the great kindness which has been extendled to me by almost everyone, irrespective of social position, to whom I have applied for information. To all my sincerest thauks are due. Bnt my warm personal thanks are due to the Rev. Jon. Shortt, B.A., Vicar of Hoghton; James Pye Whittle, Esq., Lo' gridge; the Right Hon. Sir Ughtred Kay-Shuttleworth, Bart., M.P. ; the Piev. F. A. Cave-Browne-Cave, M.A., Vicar of Longridge; the Rev. Charles Boarlman, D.D., St. Wilfrid's, Longridge ; the Rev. H. Archibald, Longrilge ; Iohn Well, Esq., J.P., Leagram Hall ; James Tullis, Esq., Preston ; Rev. Thos. Walton, Alston Lane; Mr. William Bunrue, Walton Fold; A. Hewitson, Esq., "Preston Chronicle" ; Rev. F. D. Pritt. M. A., Vicar of Grimsargh; Jas. Mckiay, Esq., "Preston Herald" ; Rev. John Morris, S.J., St. Nary's Hall, Stonyliurst; Mr. John Arkwright, Lnue street, Preston; Mr. H. Hoole, Preston ; Joseph Gillow, Esq., Bowdon; Frederick Openshaw, Esq., J.P., Hothersall Hall ; F. J. Mackney, Esq., British Museum; the Very Rev. Monsignor Gradwell, Claughton; 
the Librarian of Stonyhurst College (Rev. Fr. Gerrard) ; the Librarian of Manchester Refereuce Library (Chas. W. Sutton, Esq.) ; Mr. WV. WVaddington, Burnley; J. J. Myres, Esq., Preston; Rev. J. B. Jones, B A., Chipping; Mr. A. Stevenson, Longridge; Rev. W. Pilling, M.A., Ribbleton; Rev. I. J. de Crryse, Chipping; Rev. F. E. Roche, Lee House ; Rev. M. Brierley, The Hill ; Rev. B. Nightingale, Preston; Col. Fislıwick, F.S.A., Rochdale; and the Rev. Francis J. Dickson, M.A., Rector of Ribchester. To Mr. J. P. Whittle, Mr. McKay, Rev. Mr. Shortt, Rev. Dr. Boardman, and Rev. Mr. Dickson, I am under the greatest possible obligation for the valuable assistance they have so kindly rendered me in various ways, but especially in revising the social and political, ecclesiastical, and historical chapters.

The chapter on the geology and botany of the district, written by my friend Mr. F. C. King, will, I am coufident, add immensely to the interest and value of the book, as Mr. King has for a number of years carefully explored almost every inch of ground in the district in his.'search for botanical and geological specimens. I hardly know how to express my sincere thanks to him for his kindness-may I venture to hope, what is $I$ am sure his earnest desire, that by means of what he has written, more interest may be taken in the world of nature by the people of this district.

And, in conclusion, if any additional light shall bave been thrown upon, or the knowledge increase $l$ of, the history of this part of Lancashire, the Anthor's aim and object will have been accomplished, and his labour amply rewarded.

Well Brow, Longridge, 11th Oet., $18 s s$.

TOM C. SIITH.

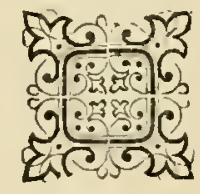




\section{CONTENTS.}

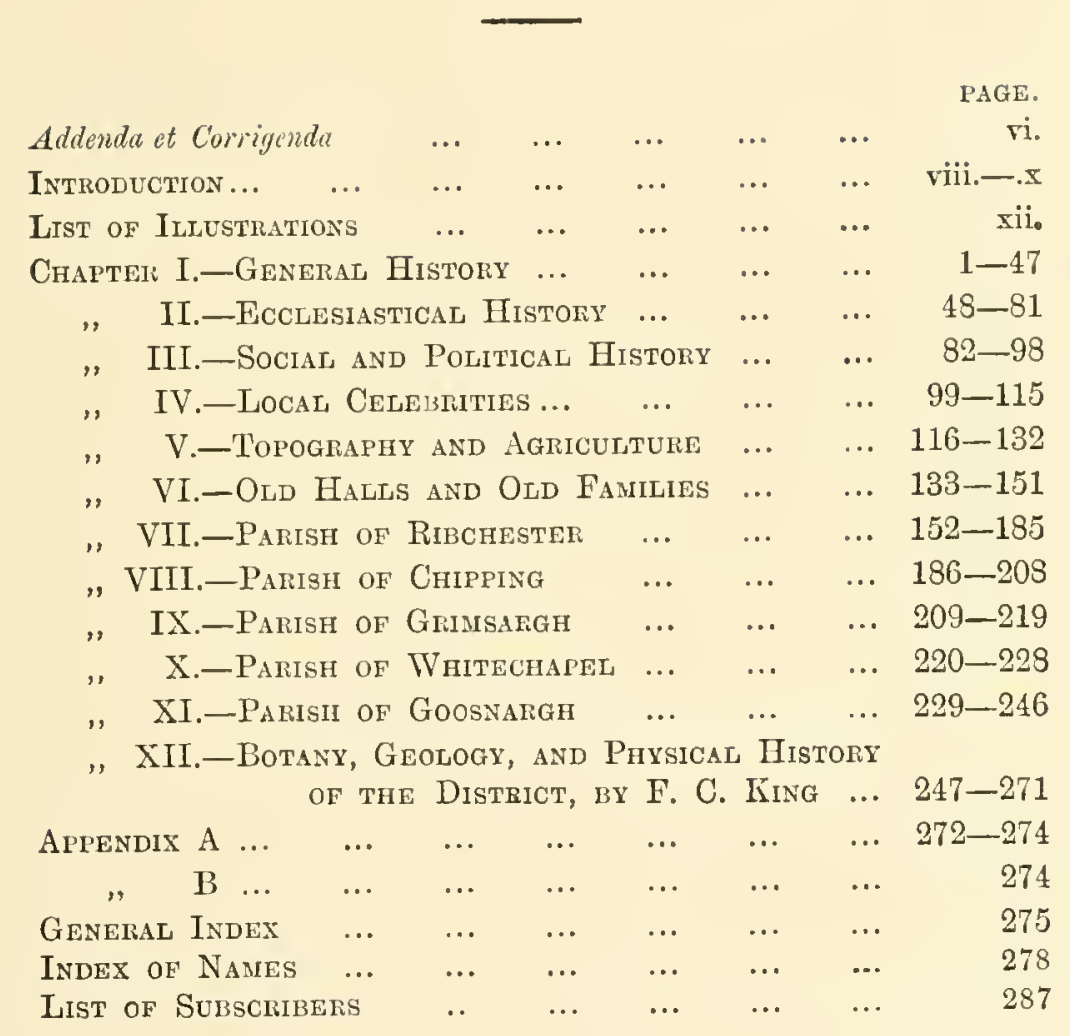




\section{LIST OF ILLUSTRATIONS.}

\begin{tabular}{|c|c|c|c|c|}
\hline Nap of the District & $\ldots$ & $\ldots$ & Facing & itle Page. \\
\hline Written Stone ... & ... & ... &, & Page 27 \\
\hline Bishop's Chair and Processional Cross & .. & & $"$ & 74 \\
\hline Portrait of George Whittle, Esquire & $\cdots$ & $\ldots$ & $"$ & 102 \\
\hline Stydd Church (South-east view) ... & ... & .. & ," & 166 \\
\hline Font in Chipping Church... $\quad \ldots$ & .. & ... & $"$ & 191 \\
\hline Grimsargh Church (South view)... & $\ldots$ & $\cdots$ & $"$ & 210 \\
\hline St. John's College, Grimsargh $\quad \ldots$ & ... & $\cdots$ & , & 216 \\
\hline Plate I. (Section of District) & $\ldots$ & $\ldots$ & $"$ & 247 \\
\hline Plate II. (Fossils from Thornley) & $\ldots$ & . & $"$ &, 251 \\
\hline late III. (Lancashire Asphodel) & $\ldots$ & $\ldots$ &, &, 25 \\
\hline
\end{tabular}

\begin{tabular}{ccccccccc} 
Arms of Cave-Browne-Cave & $\ldots$ & $\ldots$ & $\ldots$ & \multicolumn{2}{c}{ Facing page 71} \\
, & Hothersall & $\ldots$ & $\ldots$ & $\ldots$ & $\ldots$ & $\#$ &, 132 \\
$"$, & Cottam & $\ldots$ & $\ldots$ & $\ldots$ & $\ldots$ & $\ldots$ & Page & 144
\end{tabular}

* *The Illustrations are from photographs taken by Davis and Son, Lancaster and Preston. The portrait of George Whittle is copied from a photograph in the possession of James Pye Whittle, Esq.; the view of St. John's College is from an engraving in the possession of the Rev. T. Abbott Peters. The Plates are engraved by James Miller, of Preston, from drawings by Mr. F. C. King. The Cave-Browne-Cave coat of arms is from a plate in the possession of the Rev, F. A. Cave-Browne-Cave. 


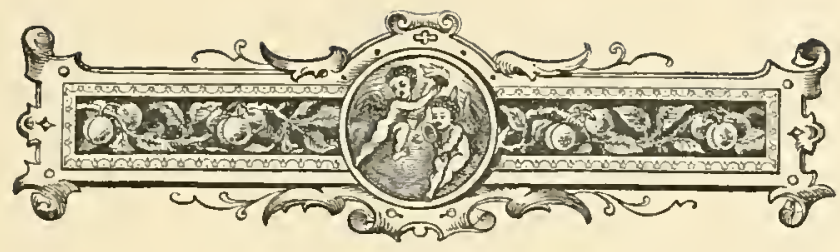

\section{CHAPTER I.-GENERAL HISTORT.}

Philological History-Situation-Roraan Roads-Rev. Mr. Just--IV. T. Watkin-1)r. Stukeley-The Britons-liev. J. Davies-Superstitions-Rev. W. ThornberDomesday Survey-Taxation in 1199-J. R. Green-Ancient Charters: Allan de Singleton-R. F. Ulfy-Thomas de Singletone-Adam de Hoghtons-KuerdenCommon lands-Roh. de Pokelingtone, Parson of Ribchester--Robert de Hodersall -Horse stealing, 1357-Theft of Hour, 1355 John de Knoll-Sir H. de HoghtonR. de Towneley-James Straytburell-Lawrence Cotom-Curious rents-Dr. Boardman on Norse customs-Sir R. de Hnghton-Thomas Houghton-Lords of the Manor-Croston Social life in XVI. Century- "The Songe of Flodden Field" "Obstinates" in 1576-lieligious state of county - Manor of "Longhridge"-Muster of Soldiers, 1503- "Fifteenth," 1583-List of gentlemen, 1588-Taxation, 1601- "Fiftenth," 1624-Recusants, 1603-Michael Drayton, 162:2-River Savnck -Leland-Harrison The battle of Longridge, 1648-Captain Hodgson-Local relics and traditions-The "affair" at Ribchester, 1643-Poverty at Longridge, 1650-Sad state of Lancashire-Written Stone. 1655-Ralph Radcliffe-Local traditions-The Stomykurst Magnine-1ixtracts from registers-List of famers, 1673-Charles Hoghton, 1701-The "affair at Preston." 1715-Non-jurors, 1715The rising of 1745-Cotton Mill on the Hodder-'Testimony of George FicclesStonyhurst College - "Merie Saung of a Chilunender," 169s-J ungridge GuildsLongridge snciety, 1760-T'owu's meetings- "Lumdon Jak"-Salary of INolecatcher, 1790-Handloom wages-Ductor's bill, 1796-Poor MIary 'Jhroup-Pathetic letters -Illegitimacy, 1826-29-Riecent custom - "Papists" " assessments, 17 59 -Longridge and Kibchester at variance, 1813 -The "Select Vestry," 1820-Longridge in 1800, reminiscence of Mrs. Eccles - Serious fire, 1826- "Lrief"- Puritanical fit, 1829Preston and Longriclge Railway, 1840-Accident, 1867-State of trade, 1830-50Decrease of population The stone trade-Military canm, 1854-Flag erected on Tootal Height, 1856-Murder of An Walne, 1862-Cotton lock-out, 1878-The Jubilee celebrations, 1887 .

For a very long time the name of the tomn whose Listory I am writing had no legal existence. It was a "courtesy-name" given to the two tomnships of which the town is composed. In 1868 the Eeclesiastical district of Longridge was formed (nuder Lord Rlandford's Act), the chapel-of-ease under Ribchester becoming the Parish Church of Longricke. Again, in 1883, another important step was taken to alter the state of confusion whicis liul prevailed by the formation of a Local Board district, co-tenminous with the Ecclesiastical district.

The origin of the name Longridge has been stated in the introductory chapter. 
The philological meaning of the words "Alston" and "Dilworth" - the tumnships of which Longridge is composed-is not so plain as in that of Longridge.

The varions ways of spelling the word Alston are:-Actun, 1066; Alsden, 1311; Alston, 1469; Howston, 1650. There can, I think, be little doubt that the Saxon way of spelling the word was Athelstone, being so called after King Athelstan, who defeated the Danes and Scots in a great pitched battle that took place in 936-39 on the banks of the Ribble, near Elston. The derivation of Alston may therefore be-Athel; stone, the house of Stone, or castle (Scandinavian "Stein.")

Alston-A.S. Athel's-ton, the town of Athelstan.

Dilworth is spelled in a great number of different ways:-Not known-1066; Dylleword-1199; Dilwhre-1210 (?); Dileworthe1227; Dilivord-1254 (?); Dilleworth-1291; Dylleworth-1292; Dilleworthe-1303; Dileworill-1311; Dilworth-1650. The origin of the word appears to be Dil, an idol ${ }^{1}$ and A.S. worth, an enclosure; the meaniug being the enclosure of idols.

Dr. March gives the origin of the word Dilworth as follows: "From O.H.G. telen, A.S. dilgian, to destroy: 8th cent. Dilli, Thilo," thus making the meaning "the enclosure of destrnction."

The parish of Longridge, as has beeu said, comprises the townships of Alston and Dilworth. It is estimated to contain 3,215 statute acres (Alston, 1,989 acres; Dilrorth, 1,226 acres). For miles around, the town of Longridge is a prominent object in the landscape. Built on the south-western odge of the fell which bears its name, its situation is very picturesque. On the east the range of hills, of which Pendle is most conspicuous; on the north-west Parlick Pike and Bleasdale Fells shelter the lovely Vale of Chipping and Lengram, through which the Hodder runs its rapid course, and the sluggish Lond winds like a serpe.st. On the west is Beacon Fell, and further still the lofty buildings of Fleetwood and Blackpool are plainly visible; the estuary of the

1The weak point-perhaps fatal-of this derivation is that Dil is British, and worth Anglo-Saxon. The Very liev. IIonsignor Gradwell, however, says in a letter to the author: "Dilworth, the idol's enclosure, is fully sanctioned by, Dr. 'Taylor in his 'Names and Places.', 
Ribble, and beyond the TVelsh hills, are to be seen to the south; and almost at your feet is the Ribble-."Lancaster's greatest glory"flowing throngh Ribblesdale past many a beauteous and historic spot.

It is not necessary for me to say anything about the geological formation of the soil, as an authority on the subject, my friend, Mrr. F. C. King, has kindly undertaken to fully deal with it.

From the information given in the Domesday Book, we gather that the district contained in early times large forests, and that bogs and morasses were very numerous. I am acquainted with a gentleman who saw a man kill one of the last of the wild deer which formerly" abounded in the neighbourhood of Longridge.

\section{Tine Romans.}

This is not the place to enter into any clescription of the state of the coantry, or the habits and customs of the people in British or Roman times. The matter has been fully and ably treated in numerons works, to which I refer the reader.

There are now clear traces and remains to be seen of the Roman roads and bridle paths in the district; and Hardwick states that a Celtie stone hammer ${ }^{2}$ was found about 30 or 40 years ago at Longridge.

In speaking of Roman roads much confusion will be created unless the following considerations are borne in mind:

"The Romans constructed three kinds of roads. The first kind during conquest was the "via militaris,' properly so called, or the elevated highway from military station to station. The second was the 'via publica,' or public road, made subsequently for intercourse from one place to another, and to facilitate the arts of peace and communication with the Roman capital. The third were the private roads, or 'vie private,' called also 'vie vecinales,' because, according to Ulpien, "ad agros ct vicos ducunt' (they lead to the fields and villages)." The average width of these military or elevated roads "was about forty-one feet or a little more. The public roads were not necessarily paved or straight. They were covered with gravel, and were fourteen feet wide. The private or vicinal roads trere less broad, seldom exceeding seven

${ }^{1}$ It is now in the Museum at Preston. 
feet in width. They had also cross roals leading to less frequented places than the ordinary roads. Many of our high roads, public roads, and bye cross roads were on the lines laid out by the Romans." "

'The "Itinera" of Antonimus is the chief authority of Roman times that $\pi$ e have. It is variously ascribed to Julius Cresar, Antouius Augustus, and Antoninus Augustus.

The best modern authority is the late lamented W. Thompson Watkin, from whose Roman Lancashire we obtain the following interesting information about the Roman roads in the neighbourhood of Longridge :

Ribchester appears to have been connected by a direct Roman road with Lancaster. Leaving the castrum it runs north-west, a nodern road being formed upon it, past a place called Dale Hey, another called Pinfold, and so on to a place called Preston Wives, where it crosses at right angles a road leacling east-north-east from the village of Longridge. ${ }^{2}$ About this spot there can be little donbt it was formerly crossed by the road from Overborngh, which, where last traceable on Longridge, is aiming in a direct line for Walton-le-Dale. The Lancaster road keeps on past "Written Stone," where, as a still-used road, it terminates; but passed on near Stony Croft, and by various fragments now used as lanes, is traceable by "stony Lane farm," "Windy Arbonr," near Lickhurst, Broadgate, Stangate "Street farm," near Stonehead, about a mile and a half north-east from Shireshead, and appears to liave fallen into the road from Walton to Lancaster, somerwhere near Galgate. The Ordnance Surveyors have marked a Roman roal only as far as "Preston Wives."

The roal from Manchester to Ribchester is generally considered to have been continned forward up to Longridge, communicating with the station by a short road from the point where it forded the river, but. as usual, near the station the traces of it are lost nutil we come to Cherry Gate (or Yate), where a road called Stoney Gate Lane ascends the hill. This, though a zig-zag road, is occasionally upon the track of the loman road, thongh in most places the latter is to the left of the former, being plainly visible. It continues thus to the summit of the hill, where, near a point called "Jeffrey Hill," it falls at almost right angles on the road which I have before named as pointing for Walton.

Traces of this road are clearly visible now.

Dr. Stukely, accompanied by Roger Gale, visited Ribchester in 1775, and in his "Iter Boreale" gives a graphic description of the place.

${ }^{1}$ Rev. Mr. Just, of Bury-"Laneashire and Chcshire Historical Society," vol. I., p. 69.
${ }^{2} \mathrm{~A}$ glance at the map which accompanies this work shows better than any description the course of these ruads. 
He mentions a street which is the Roman roal ruuning directly northward up the fell called "Green Gate." "It passes over Langridge, so through Bowland Forest."

\section{The Axcient Britons and Shxoxs.}

Perhaps a brief account of the religion of the Ancient Britows ${ }^{1}$ and Saxons, and Danes, should be given, as many places in the district still retain the names of the heathen places of worship, and some of the eustoms of the people may be due to the sacred rites of the Pagan inhabitants. The Rev. J. Davies states:-

In the middle of the county we have Angle-Zark. The first part of the word is, without donbt, from the name of this [Angles] tribe; the second is found also in Githousargh, Kellamargh, Mansargh, and Coosnargh, all names of places not far from Anglezark, and is probably the old High German haruc, old Norse hörgr, Anglo-Saxan hearb, gen. heurges, a heathen temple or aitar. The old Norse hörga (ns:retum editius) shows that it means primarily a lofty grove, and thence a temple encircled with groves (according to Bede's description of a heathen temple, " fanum cum omnibus reptis suis"), and, lastly, a tumple. It answers, therefore, to the Danish lund (a sacred grove). We know from Tacitus, that all the Germanic races were wont to celebrate the rites of their dark and cruel worship in the gloomy shades of forests or groves, and the worl teaches us, as W'edneshough (Wodensfield), sitterthoaite (Setere) and Lund, that the Angles were worshippers of the old Teutonic deities, when they took possession of Lancashire. The name was probably given by the Angles themselves; and, if so, it indicates that the Anglian speech approached, in some words, to the high Gcrman form.

The Rev. TV. Thomber, referring to the ancient superstitions still lingering in the Fylle and other parts of Laneashire, says:-

The conjoint rorship of the Sun and Mloon, the Samen and Sama, husband and wife of nature, has been from these early times so firmly implanted that ages have not uprooted it. Christianity has not banished it. The Saxons were guilty of it. $\mathrm{Xay}$, in my youth, on Halloween, under the name of Teanlu fires, I have seen the hills throughont the country illuminated with sacred flames, and I can point out many a cairn of fire-broken stones, - the high places of the votaries of Bel,-where his rites have been performed on the borders of the Ribble age after age.

1 Iunsignor Gradwell states that Edcli, in his "Life of St. Wilfricl," distinctly tells us that Aegfritlis found British priests in Lancashire, and tlat they held lands on the banks of the libble. 
THe Normans.

In the Domesday Book Actun (Alston) is stated to have contained one Cameate of land; while Dilworth is not mentioned at all, the land evidently being " waste;" making a total of one Camucate" for Longridge in the eleventh century. "Roger de Poictou," says the Domesday Book, "had" the whole of Amounderness, which, at that time, included Ribchester and Dilworth, places now in the Hundred of Blackburn. Probably this district was covered in those days with large forests, about which Leland makes the following remarks:-

All Aunderness for ye most part in tyme past bath bin full of wood, and many of ye Moores replenished with firre trees, but now such part of Aunderness, as is towarls ye Se, is sore destitute of wood.

In the 20th year of the reign of King Edward III. (1347), the Abbot of Cockersand assumed that, by a charter of King John ${ }^{2}$ (11991216) he was exempted from the payment of rates and taxes in certain specified places. Dylleword is mentioned amongst the number.

Mr. J. R. Green, the historian, in an article which appeared some years ago in Mucmillen, points out the significance of these charters, numbers of which were granted by John and Richard. He considers it was the wise and deliberate policy of these kings and their ministers which lairl the foundation of English freedom and liberty, and also enabled the people to pursue their business undisturbed by outside interference.

In 1199 "War' fil' Rob'te de Hodreshall" owned 2 borates of land " in Hodreshall."

In the same year Ric'us de Moghton MLil. dedit cuidam capellano quas' trus eum pertin' in Dutton, Ribblecester, Chejyn, Gosnargh, Hodersale, $A$ gliton, etc. ${ }^{3}$

Allan de Singleton, son of Richard, confirmed Deo et Sancto Salvatori de sub Langrigh et fratribus ibidem Deo servientibus "four acres in Dilwhre, scil inter Cronekeschuthebrol ct Withacrobrock, which his father had given him."

1 A Cumcate, carve or plough land, was generally about one hundred acres. It is probable to this charter that a claim, without late, yreserved by Kuerden, from the men of Ribchester, Dilworth and Dutton, to be free from fines, amercements and tolls in all markets, and fairs, and from suit and service iu the county and wapentake, refers.

"Tregson's "Fragments."

4 Whitt. Whall. ii., 46 ? 
A fine was made at Laneaster, 14 Jan., 1227, "inter -1 vicum que fuit uxor Will. Brun et Rob. Plumbe et Cecilliam uxorem gus petentes et Rob f Ulfi tenentem de unce borata et tribus partibus unius boote terre cum pertinenciis in Dillworthe, unde rccognicio magne assise summonita fuit inter cos in eadem curia," by which $R$. f Ulfy acknowledged the tenement to belong to Avicia, Robert, and Cecilia ; for the reeognition fine and concord they gave him the mediety of the land; "scil illam medietatem que ubique jacit vcrsus umbram," to be lreld by Robert f Ulfy and his heirs from Avicia, Robert, and Cecilia, and the heirs of Avicia and Cecilia for ever, paying them 22d. a year on 1 Sept., of whieh they will aequit Robert F. Ulfy and his heirs, "Tersus capitales Dominos de viginti et uno denariis singulis in perpetun. Et preterea respondebunt de servicio quod ud medietatem suan que eis remanet in dominieo capitabibus dominis fead i"

Richard de Singilton "Nelior do Ordishalh" gave the monks certain lands in Hothersall and Ribchester for building, hurning, and enelosing "beute Marie de Sallai" "Preterea dedi eisdem Monuchis Mortum bascum ad omnia necessaria sua facienda capiendum ubiqu infire divisiis bosci ville de Ditword," and pasture in all the common in Dilword and hibeestria, "Sexaginta averiis et $x x^{\text {ti }}$ Equabus cum sequela trium annorum for 400 sheep and 20 sows cum sectr unius anni et percellis suis," rithont pannage. Witnesses, Simon Heriz, R. de Miton, Elia de Knol, et aliis. ${ }^{3}$

\section{The Plantagenets.}

At Lancaster Assizes, $30 \mathrm{July,} \mathrm{1291,} \mathrm{an} \mathrm{assize} \mathrm{eame} \mathrm{to} \mathrm{know} \mathrm{if} \mathrm{Rob.}$ f Elye de Rybbelcestre, Rob. le Eyre, Wil. f ejus, Ric. Frannceys, Rob. de Duyetehalghe, Ric. del Hurst, Wil. le Spencer, Ric. f Elye, and Tho. de Radulfi, unjustly disscised Thomas de Syugeltone and Adam de Hoghtone of 60 aeres of land and 12 of wood "per diversu locu in Dilleworth." Robert and all the others eame and said that these tenements are "quedam placee in quibus communam pasture habere debent." Thomas and Adam said that there were two places which they harl

1 Feet of Fines, Hen. TII., No. 21.

${ }^{2}$ Is in so many other country places this common land, upon which not only the poor man's herd might pasture, but also upon which the youth of the place might disport themselves in manly games, has been sequestrated by some lind glutton.

Harl. MSS., $112 \mathrm{f}$. 
inclosed, one for a year, and the other for five weoks, until Robert and the others levelled a paling they had made round them, and they said besiles that they are lords of the said town, and that there is sufficient pasture for Robert and the others "ad tenementa sua extra predicta placeas." The Jury found that Thomas and Adam are lords of the land "et soli predictarum placearum" and inclosed the places and kept them enclosed until Robert and the others levelled the paling, and that Robert, ete., had sufficient pasture for their holdings, and free entry and exit "pretor predictas placeas incluses." Et dieunt precise, that Robert, ete., unjustly disseised Thomas and Adam, who are, therefore, adjudged to recover seisin "per risam reognitorum," and the others are fined.

At Lancaster Assizes, July 1292, Tho. de Singelton and Adam de Hoghtoue were sued for unjustly disseising "Rob. de Pokelington personam ecclesie de Rybbelcestre" of the eighth part of 200 acres of wood and 100 more "et bruers" in Dylleworth. Thomas said that Katerina, formerly wife of Alan de Singleton, his father, and 'Thomas de Clyftone, now her husband, holds a third part of two parts of the said tenements in dower. Adam said that "Agnes matertera suu" held the third part of tro parts of the said tenements in dower. Robert could not gainsay that Agnes and Katerina held these third parts, and therefore took nothing by his writ and was fined for a false claim.

Op 15 July, 1292, Rob. de Pokelingtone persona ecelesie de Ribbelcestre sued Thomas de Singeltone, Adan de Hoghtone, Thomas de Clyftone and Katherina, his wife, and Agnes "que fuit uxor Ade de IIoghtone, de octare parte Duecntarum acrarum bosci ct Duecntarum acrarum pastere more Bruere et Brussiti" in Dillewortl.. Adam de Hoghtone said that he inherited the mediety of the said tenements from liis father, Adcm de Hoghtone. Thomas de Singeltone said he held the fourth part by gift of Robert Mutin, who is living and who is not named in the writ. Tobert said that after this gift he was in seisin of the tenements as a freehold, which Thomas denied. The jury found that Robert never was in seisin, and so could not be disseised. $\mathrm{He}$ was therefore fined for a false claim. 
By fine made at York, 25 June, 1303, "inter Rob. de Shereburs querentem et Johannan que fuit uxor Tho. Bunastre deforcientem" the manor of Little Singeltone and four messuages, one mill, 16 bovates, and 116 acres of land, five of meadow and 20 of wood, in Thorntone, Broghton, Dilleworthe and Billesburgh, were settled on Johanna for life, with remainder first to Will. Banastre and the heirs male of his body, then to Adam, brother of William, and the heirs male of his body, and then to the right heirs of Jolanna. Dominus Adam Banastre held half a carucate in Dilleworthe for $2 /-$ a year. ${ }^{1}$

Ric. f Ade de Houghton gave Richard, his son, his manors of Alsdeu, Hodershall, and Dilworth in Ribchester, with the services of all their free tenants, to be held of the chief lords of the fee, dated at Alston, 29 \[ar. 1312.

Between 1216-1300, "Nichs. devias and Robt. de Holand" ton. in scitu medietat' manerii de Alston $p$. servit' ijs $p$. ann. Thomas de Irodersall surviciun vs p. ann. ad quatuor term' Wills de Eton tenet villam de Grymesarigh p. serviciu iijs. Rogerus de Etholston tenct in villa de Goose-

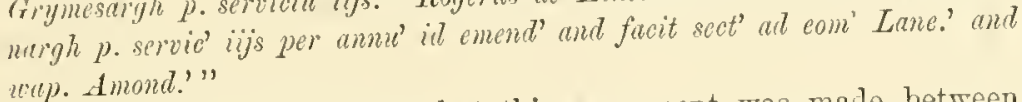

"This document testifies that this agreement was made between Robert de Hodersall on one part and Adam, son of Adam de Hocton, on the uther, on the Saturday after the Ascension of our Lord in the 20th year of Edward in the town of Preston, that as disputes had arisen with respect to lands and tenements in the vill of Hodersall that had been taken possession of, in order that peace and good-will might be between the same, it was decided that the sail Robert and Alam placed themselves mder arrangement (ordination) of the six men underwritten, viz:-Adam, son of Thomas de Hudersall, Adam de C. Ilurst, Richard, son of William, Henry, son of Stephen, Richard do Ametshngh, and Benedict de Hull; so that whatsoever the same six shall ordain between the same they shall hold as decided; so that if R.bert took in his time anything from the part belonging to the said Alium, or held it unjustly; upon the view of the saicl persons, it be fainly set right; and if the lord Aciam de Ilocton, father of the saicl

Inq. 1311. 
Adam, in his time took anything from the part of the said Robert, it should by the same persons be set right, in regard to woods, plains, pastures, meadows, and in respect to roads and all other places, and for greater security they placed themselves under the jurisdiction of the Tiscount (?) of Lancaster so that the agreements might be liept. And for 20 shillings a "divestiamentum" to Lord Eclmund, illustrious son of the King of England, and for a mark of the need of the said (?) and for 12 pence for the noed of those serving each day. How far the said agreements were carried out, and that this arrangement was established against Michaclmas of the aforesaid year in proof they have set to their seals. These being witnesses:- IVilliam Brochull, John Grimsargh, Robert, son of Adam de Preston, Adam, son of Ralph of the same, John de Farrington, and others. 20 Ed. I., 1292."

"Edwarl, by God's grace King of England, to greetings Adam de Hocton, knight, has complained to us that Adam, son of Robert de Hoddersall, and Johanna, his wife, Adam de Threlfall, aud Matilda, his wife, Elias de Entwishull, Robert, son of Adam de Honlden, Richard, son of Adan de Holden, John, son of Robert de Cundeliffe, Robert Dane and Richard, son of Joln de Hudersall, have unjustly and unlawfully disseised him of his free tenement in Hudersall. Date 36, El. I., 1307."

"Robert, son of Thomas de Huddersall, gave to Richard, his Trother, all the land that Richard de Bradley and Agnes, his wife, held from him for the term of their life. "Which land lies in Hodersall between the land of my aforesaid brother Richard on the south side aurl the land of Simon do Bradley on the north side.'

"These being witnesses:-Robert, son of Robert Motton, Richard, son of Adam Moton, Thomas de Bradley, Robert Frauvceyes, Roger de Ellate, and others.

"Given at Hoddersale the day of March next, before the feast of the Nativity of Saint John the Baptist, the 16 year of Ed. the Third, 1343."

Accorrling to the inquest taken on the death of the last of the Lnceys (1311), in which it is called Dileworth, the basis of the township was one caruente of land. 
"In 14. Elw. III. (1341), Hugh de Rochefort (the rupe forti), plaintiff, and Fromund de Northampton, and Hawise, his wife, deforciauts, of a moiety of the manor of Alstou with the appurtenances."

"By fines made at Preston, 29 Feb., 1357, Joh. de Turnelay aud Cecilia, his wife, gave Ric. $f$ Ade Riblechastria one mesauage aud 12 acres of land in Whittacre and Dilworth, with warranty from themselves and the heirs of Cecilia. For this he gave them 20 marks of silver."

"At Clitheroe, 6 June, 1358, the jury of the Sheriff's bar, of Blakeburnshire, found that Joh. del Slake (ontlawed) 'quondan manems in Chepyn' felonioulsy stole a mare worth iiijs de 'Rie de Dilleworth Bucher Apud Dilleworth.' 13 Sept., 1357."

At Preston Assizes, 23 Feb., 1355, the jury of Aumunderness presented that Adam de Rishtone manems in Hodersale (in prison) felonionsly broke the mill of Alston on Suuday, 7 Dee., 1354, and stole a sack with half a quarter of wheat worth 4s., and on $21 \mathrm{July}$, 1354, he stole 2 heifers worth 6s. 8 d. from Rob. f Rob. f Will. de Hodersall, in Hodersale; and that Hen. de Hoghtou (outlawed) was aiding aud consenting in the said felonies and taking part. Ou 3 Narch, 1355, a jury aquitted him of these offences, but the sack is said to have contained wheaten flour, and he is cliarged with stealing two mares (duas Jumentas) worth 6s. 8d., on 21 July.

JOHN DE KNOLL.

$$
\text { “22 Richard the Second, 1398-9. }
$$

"Information as to the cause of the taking into the hand of the Duke in the year 22 of Richard the Second of lands which belonged to John, son of Richard de Knoll, in Chepindale.

"The King, by writ of William de Singleton and Adam de Whytingham, committed to Robert de Singleton the custody of all the lauds aud tenements and rents in Chepindale which lately belonged to John, son of Richard cle Knoll, pertaining to the ling as escheator, to beheld for the term of 10 years, paying $13 \mathrm{~s}$. $4 \mathrm{~d}$. a year.

'Gregson's "Fragments." 
"Giren 13 August, 10 Henry 4, 1409.

"Tenor of the aforesaid Petition: To our Lord the King, beseeching very humbly Geoffray de Werburton de Nerrcrofte, and Katerine, his wife, complain how they were peaceably seized of a messunge of 14 acres of land and 12 acres of meadow or the appurtenanees in Chepyn in the county of Lancaster for term of the life. The said Katerine had the reversion in respect to Laurance de Knoll, son and heir of Thomas de Knoll, Baron, the said Katerine as if [as well as?] the King our Lord. The King, by evil suggestion made to his council without any title or business found by him, left the said lands to Robert Singleton for a term at a rent of 20 shillings a year. ${ }^{1}$ "

John de Chippendale in Boland to Sir Henry de Hoghton, all lands in Hothersall. 3 Henry V. [1416].

Henry de Hoghton, letter of attorney to take possession of lands in Hothersall, given by John de Chippendale. 3 Hy. V. [1416].

Robert Huthersall, letter of attorney to give seizin to John de Hoghton of all his lands in Hothersall and Ribchester. $3 \mathrm{Hy} . \mathrm{V}$. [1416.]

Richard de Hoghton, son of Henry de Hoghton, Knight, to James --, lands in Newton-in-Bnlland and Hothersall. $10 \mathrm{Hy}$. VI. [l432.]

"In Hen. V. [1413], James Clyfton and others held the vills. of Goosnargh, Chepyn, and Rybchester."

HENRY DE HOGHTON, KNIGHT.

$$
\text { " } 3 \text { Henry VI., } 28 \text { May, } 1425 .
$$

"Inquisition taken at Preston before Kichard Botiller, of Kirkland, on Moulay next after the Feast of Pentecost in the third year of Henry the Sixth, on oath of William de Farryngton, Hugh de Orrell, Gilbert de Haydok, Thomas Faryngton, Robert de Singleton, Joln Blundell, John de Nersum, Richard de Plompton, and others, who say that Henry de Hoghton, Knight, held on the day he died the manor of Chepyn of the Lord the King in chief, as of his Duchy of Lancaster, in socage, and by service of a shillings annually. And it is worth by the year clear 40 shilliugs. Likewise he held half the manor

\footnotetext{
${ }^{1}$ From a bundle of Inquisitions of the time of Henry VI.
} 
of Hodersall and an eighth part of the said manor of Hodersall of the Lord the King in ehief, as of his Duehy of Laneaster, in socage and by serrice of $2 \mathrm{~s}$. 6d. annually. And it is worth per annum clear $40 \mathrm{~s}$. Likewise he held half the manor of Dilworth from tho heirs of Osbert de Dilworth by what service they know not, and it is worth per annum clear 20s. Likewise he held a parcel of land in Hodersall called Ulmon Ridding of God and St. John of Jerusalem, by what service they do not know. And that he died on the Saturday next before the feast of St. Andrew the Apostle, in the third year of Henry the Sixtl. And that Richard, son of William de Hoghton, Knight, is kinsman and next heir of the said Henry, viz., son of William, son of Richarel, brother of the said Henry. And that the said Riehard, son of William, of the age of twenty-six years and more."

"In 10, Hen. V. [1422], Rieardi Haughton, mil, held the mannors of Grymesargh and Alston, and lands in Elston, and mills, ete., in Gosenargh and Threlfall."

"Huetred de Huddersall surrendered to Richard de Hoghton, Knight, all the rights which he had in all those lands and meadows, with their appurtenanees, "which the aforesaid Riehard holds by my gift and feofment in the vill. of Hodersall. So that neither I nor any one else can of our right elaim any thing.' Given at Hodersall at the Feast of the Purifieation of the Blessed Mary, in the 19 year of Henry 6. [1441."]

"William, heir of Thomas de Hoghton, and Alice, his widow, to Utred do Hothersall, all their lands and tenements in Hothersall and Alston. 20, Hy. VI. [1442.]"2

"Rcger de Ethelston, son and heir of Nicholas, to Roger de Towneley, release of his lands in Ribchester, some time of Henry Hoghton and John Whittaker: 24, Hy. TI. [1446.]"1

"Richard de Hoghton, son of Menry de Hoghton; his letter of attoruey to deliver possession to Richard Towneley of all his lands in Hothersall, exeept one elose ealled Hothersall-hey. 24 Hy. TI. [1446. $]^{21}$

Towneley MSS. 
"Richard de Towneley; letter of attorney to Ralph de Towneley to talie possession of the lands in Ribchester and Hothersall of Richard de Hoghton, son of Henry de Hoghton, 25, Hy. VI. [1447.]"

"Richard de Hoghton, of Laithgreen, son of Henry de Hoghton, Knt., to Richard de Towneley and his heir; all his lands in Ribchester and Hothersall. 25, Hy. VI. [1447.]"1

"Io. Whittaker to William Cottam, of Dilworth, all his goods in Ribchester. 18, H. VI. [1440.]"

"Thomas de Ratclyfe's release to Thomas do Ethelwick and Jo. Ratlyfe; lands in Ribchester, called Kendall-hey, \&c. 21, H. VI. [1443.]"

"Thos. fil. Robert de Ratlyfe to Jo. de Elliswick and Jo. Ratlyfe; parson's lands in Ribchester, \&c. 21, H. VI. [1443.]"

"This Indenture made between Henry Hoghton, Esq., son and heir of Sir Riehard Hoghton, Knight, and William Cotom, of Alston, witnesscth that the said Henry has granted to said William one place of land in Dillworth after decease of his fader, dureinge the life of the aforesaid William, payeing therefore yearly $32 \mathrm{~s}$., and after the decease of the said Wm. to Elyes Cotum and Edmunde Cotume, sonnes of the said $1 \mathrm{Wm}$., unte the terme of their lives. Gyffen at Sidgreaves the 20th day of Febr., ye 5 Ed. 4, 1466."

"Be it known that Ughtred Cotome, son and heir of the aforesaid Ughtred, gare to Robert Combilhome and William Barker, Chaplains, all our messuages and lands, together with the water-mill in the vill of Dillworth, hamlet of the vill of Ribchester, to be held by the aforesaid Robert and William, and their heirs, of the chief lord, paying therefor yearly a red rose, if required, at the season of roses. ${ }^{2}$

${ }^{1}$ Towneley MISS.

"This curious mode of "service" or rent was very common in the fourteenth aul fifteenth centuries.

In a graut to the Earl of Chester, bearing date 18 Uct., , the King (Henry) ranted certain lands in the county of Lancaster to Ranulph, Earl of Chester, "he (Ranulf) paying to the king and his heirs yearly at the feast of
St. Michael, a falcon, or, in place of it, 40 shillings at the exchequer, for all service."

Rol. Charter, 13, Hen. III., m. 3 .

"A rent of one ponnd of pepper per annum," was also a common rent-charge in those days.

Doubtless it was a survival of a custom. in vogut amongst the oll Norse people, as may be gathered from the following 
"These being witnesses:-Rubert Eulur'sall, Riehard Lynols, Richard Hodersall, Robert Walmsley, and Richarl Coke, and many other's.

"Given at the Nativity of Saint John Baptist, year 9, Hen. 7. [1494.]"

"Sir" Henry Hoghton, Knight, 'delivered possession to Richard do Towneley, and his lieirs, of all his lands in Ribchester anr Hothersall.'" a But the Towneleys could only have held the manors of Ribchester and Hothersall for a very short time, as in 1468-9 the following extract shows:-

$$
\text { “ } 8 \text { Edward IV., } 12 \text { February, 1468-9. }
$$

"To all Christian believers. James Straytburell, ehaplain. Whereas, I am seized for myself and heirs by virtue of a certain Recorery, before John Needham and Thomas Litelton, Justiees at Laneaster, against Henry Houghton, Esquire, among other things, of all the lands in Chepyn, I have allowed to William Hoghton, son of Heury Hoghton, Esquire, a certain annual rent of 100s. from the said laud to the term of his life. These heing witnesses, Joln Botiller, Richard Clifton, John Skilicorne, Esquires, and others.

"Given 12 day of Felmary, in the eighth year of Edward the Fourth."

$$
\text { " } 9 \text { Edward } 4 \text { (20th Mareh, 1470). }
$$

"Let all kuow. I, James Straytbureil, Chaplain, gave to Henry" Hoghton, Esq., my manors of Lee and Hoghton, and also all the lands in the Lee and Hoghton, Chirnok Richard, Whithill in le Wodes, Grimsargh, and Alston, half the Manor of Alton, and all dominical lands to the same appertaining, wholly excepted, and also all my messunges and lands in Hodersall and Dilworth, and

interesting and curious custom, taken from a very learned address delivered in 1877 before the menisers of the Mauchester Academia of the Catholic Reliyion, by the Rev. Charles Boardnan, D.D., of Longridge :-

"In the Gulathings" law it was enacted as follows (6): "We have commanded each yeoman and his wife to have an ale-making, and to ballow it on the holy (i.e., Christmas) night to Christ's bonour and Holy Mary for a good year and peace. If this is not done, they shall forfeit three marks. If the man acts thus for three years, then has he forfeited every penny of his fortune, one-half of which roes to the king, the other to the bishop. He has the choice of going to shrift," doing penance to Christ, and re. maining in Norway. If he will uot so this, the unust he leave the land of our king." " Early Norse Christianity."

1 Towneley MISS. 
likewise Chepyn, Preston in Amounderness, Golburne, Haworth, and Ravensmeyles, which, indeed, I lately recovered against the aforesaid Heury, at Lancaster. To be held, exceptions excepted, by the aforesaid Henry, to the term of his life of the Chief Lords; And afterwards they may remain to Alexander Hoghton, son of the aforesaid Henry, and to his heirs male; and without heir of the aforesaid Alexander, then to William, brother of the aforesaid Alexander, and his heirs male; And without heir of the aforesaid William, then to George, brother to the aforesaid William, and his heirs male; And withont heir of the aforesaid George, then to Arthur, brother of the aforesaid George, and his heirs male; And without heir of the aforesaid Arthur, then let them remain to the right heirs of the aforesaid Henry Hoghton. These being witnesses, John Botiller, Richard Clifton, John Skellicorne, Esquires.

"Given twentieth day of March, in the ninth year of Edward the Fourth. 1470."

\section{The Tudors.}

"Be it known that we, Robert Crombilholme and William Barker, Chaplains, gare to Ughtred Cotom and Ellen, his consort, our chief nessuage, with three closes of land, called Over Ridding, Largher Ridding, and the Holt, adjacent in the Vill of Dillworth, which we lately had by gift of the aforesaid Ughitred and Ellen for the term of the life of the same, upou payment therefor yearly of a red rose. These being wituesseiz, Rohert Hodersall, Richard Lynols, Richard IIodersall, gent, Robert IValmsley, Richard Coke, and many others.

"Given at the feest of Saints John and Paul, in the year 9 Hen. 7. 1494."

"'This Indenture witnesses that Robert Crumbylholme, clerk, IVilliam Barker, chaplain, Ughtred Cotome, and Robert Cotome, son and heir apparent of the said Ughtred, granted to Lawrence Cotome, son of Edmund Cotome, all the messuages and lands in Dillworth, in the vill of Ribchester, called Herryfall, Moton intakke, and the Copthirst, to be held by the aforesaid Lawrence for the term of fourteon years, paying therefor yearly a red rose and to the chief lords. These being witnesses, Roger Singleton, Robert Cliftun, Richard Linoller, Thomas Whittingham, Thomas Lawrence, and oihers. 
"Given the seventh day of July, iu the 18th year Henry 7th. 1503."

"Be it known, that I, Lawrence Cotom, sou of Edmund Cotom, demiserl to Ughtred Cotom, of Dilworth, all those messuages and lands, also all my right in Dilworth, aud also a certain annual rent of 13s. 4d, arising from a certain mill in Dillworth, which I lately had along with Lawrence Cotome, senior, now dear, by gift of the aforesaid Ughtred by a charter, of which the date is the eighth day of the month of Narch, in the 20th year of Henry 7th, to be held by the aforesaid Ughtred and his heirs from the chief lords. Know, moreover, that I have attornied Millon Alston.

"Given the last day of the month of March, in the 2 year of Hen. 8, in presence of John Singleton, of Clingehall, Knight, Henry Singleton, James Singleton, James Walton de Preston, John Dill worth, of Studley in Chipendale, and many others. 1511."

"It appears that I, John Lynols, gent, received from Richard Hoghton, Knight, ten pounds sterling, in full discharge of $£ 20$ specified in certain indentures made between me and Riclard, the dates of which are the fourth day of Feb., in the 20th year of Hen. 8 , for the sale as for my title, which I had in all and singular, those messuages and lands which lately belonged to Aghtred Coton, deceased, and Robert Cotome, kinsman and heir of the aforesaid Aghtred, in the wills of Dillworth and Ribchester.

"Given the 18th day of August, in the year 21 Hen. 8. 1530."

"To all true people. To Ughtred Cotum, of Dilworth. Know yo me, that I stand leased to my own use of, and in all my Mlessuages, landes and tenements in Dilwortl, and if any estate to be made by me of any of the premisses to any person, I, the said Utred, declare that every such said estate was, and is, unlawfully sealed and made, except a certaine deed, with a schedule to the same, to Lamrence Cotom, sonne of Edmund Cottom and Lawrence Cottom, the elder, and Landes in Dilworth, and alsoe a certain annuall rent of $13 \mathrm{~s}$. 4 1., goeing out of my milne in Dilworth, bearinge date the 8 day of Harch, the 20th yeare of Henry the 7 th, all which premisses the said Lawrence Cottom ha' I refeoffed to me, the said Utrede. In witness, I have set my seale, 
and for eause $y^{t} \mathrm{my}$ seale is not knowne, I have gotten at my request Sr. Edward Lypton, Sr. Willm 'Milid,' priestes, James Walton, of Preston, in Amounderness, Henry Singleton, of Broghton, and James Sington, of Gosenargh, gent, to set to their seales.

"Gifen the first day of Aprill, ye. 2 H. 8. 1511."

"This indenture, made the seacond day of Aprill, in the seaccud yeare of Henry 8, witnesseth yt. I, Utrede Cotom, of Dilworth, have granted to Lawrence Cotome, sonne of Edmund Cotome, all and singular, my meses. and lands in Dilworth, except milne, these to have and to hould to the said Lawrence and his heires for ever. In witness we have set our senle."

"Lancr. On Monday next, after the feast of the Assumption of the blessed Mary, in the year 21 of Henry 8 (No. 13.), Riehard Hoghton Miles claims against Lawrence Cotom, of Thornley, 3 messnages, 1 mill, 100 aeres of land, 20 of meadow, 100 of pasture, 2 of wood, 60 of heath, and 20 of marsh, in Dilworth and Ribchester, which Lawrentius has not, except by disseising, which Heys Hnnt unjustly . . . Lawrence ealled to warrant John Lynols, wherenpon John called to warrant Thomas Hepay. Richard claims against Thomas in the same form permission to interrogate. Thomas does not return [reply?], whereupon Richard recovered, seising against Lawrenee, and Lawrence has an equivalent from the lands of John Lynols, and an equivalent from the lands of Thomas Hepay. 1530."

"This is the final agreement, made at Laneaster in the 4th week of lent, in the 12 year of Eliz., before John Walch and Nicholas Powtrell, justiees, between Thomas Hoghton, armiger, and William Catterall, armigc", defendant, eoncerning 12 messuages, 4 eottages, 12 tofts, 12 gardens, 12 orchards, 30 aores of land, 100 of meadow, 200 of moor pasture, 40 of rood, 50 of 'jampnor' and heath, 200 of moor, 200 of turbary, 200 'messet.' [marisci ?], with appurtenanees in Goosnargh, Whittingham, Cumberall, and Dilworth, whereby thoy belonged to the same Thomas; and for this agreement the same Thomas gave the aforesaid William $£ 110$ sterling. 1570-1."

"Be it known, that I, Roger, son of Roger, son of William John Hodersall, of Hodersall, in the county of Lancaster, gentleman, and 
Richard Chatburne, of Ribchester, in the county aforesaid, sen and heir apparent of Henry Chatburne, deceased, were bound to Thomas Hoghton, of Lea, of the county aforesaid, Knight, in t0 peunds.

"Given 14 Feb., 12th year of Elizabeth. 1570-1."

"Willian, of Ribchester, confirmed to Robert, son of Adam Motton, in free marriage with Alice, my sister, my heiress, or te their assignees, a certain portion of my land in the vill of Ribchester, viz. : All that I had by gift and feeffment of Robert, son of Cristian, of Ribchester, lying near Motton hey, which is called Lomedley in length and breadth. Moreover, I gave also to Rebert and Alice, and to their heirs or assignees, one rood of land and seventeen 'Rodefulls,' lying' in a certain place which is called Tumley, in the aforesaid vill of Ribchester, between the land of Saint Saviour and the messegate, which is called Turnley Gate, and between the land of William, son of Adam, son of Elias, in length and in breadth.

"Withont date, or names, or wituesses."

"In the 32nd of Eliz. (1591), the Maner of Fodersall was held hy Thomas Honghton."

"In the 38th of Eliz. (1597), Thomas Houghton also held the Manor of Dilwortl."

Stmmarising the above charters, etc., we find that the Hothersalls of Hothersall Hall were for a loug perier Lerds of the Manor; their successors were the Singletons, then the De Honghtons, then the Stratberrells, then the Leckonbys, aud, the present ones, the Cross's. The Radeliffes, the Cottams, the Earls of Derby, the Nelsens, were also large landed preprietors.

In Crosten's "History of the Ancient Hall of Samlesbury" some interesting extracts from the Court Rells are given, from which I take the following, as they throw a vivid light upon the secial bife of the people of this part of Lancashire in the sixteenth century:-

Orders. Item. It is ordered in this Court that every person who suffereth any gannmyge (gambling) within his house or farm hold shall for every such offences forfeits and pay 3s. $4 \mathrm{~d}$.

Itcm. It is also orlered that no person or persons within the Township shall recet (receive) or maynteyn any women of light conversation either of botly or fame upon pains to forfeit for every week so offending xurd. 
Hngh Rede hath licence to keep ale honse where he hath lodged and kept men and women of evil conversation Irs. The payne for every time so doing or carding and gamynge 111s. nud.

The taxes run very high in the Township. I advise to let the tenants clear all, and let them attend the Town's meetings, and they will take care for themselves that nothing goes wrong.

In 3513 , the date of the battle of Flodden Field, a song entitled "The famous Historie or Songe called Flodden Field" was written, from which $I$ take the following lines referring to localities in this neighhourhood:-

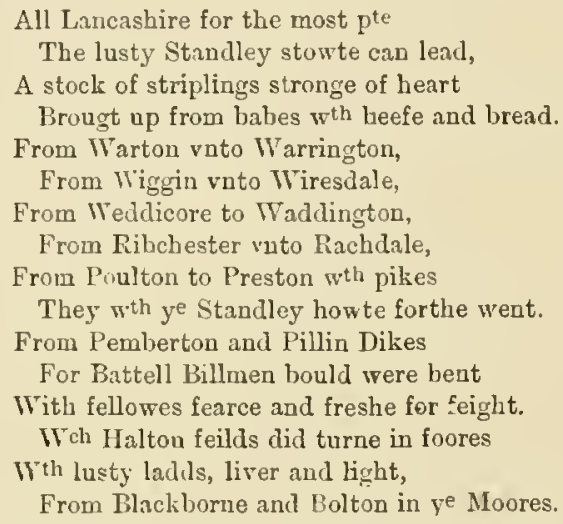

In 1576 complaints were made by Dr. Downham, Bishop of Chester, to the Privy Council respecting neglect of worshil in Lancashire and Cheshiro. Accompanying the letter of complaint were lists of "obstinates" and "Conformists."

The following "obstinates" were residents in this locality :-

John Hothersall, gen. ${ }^{1}$

John Hothersall, Husbandman.

John Sotlwworth, Knight, and the ladie, his wief.

Thomas Sothworth, his sonne and heir.

John Sothworth, gen., sonne to John Sothworth, K.

'Son and heir of Thos. Hothersall, of Hothersall, married Margaret, daughter of Mr. James Wall, in Moorside, I'res. ton. About 1584 the family were des. cribed as "obstinate recusants." Along with ten others, John Hothersall was cliaracterised as a man whose opinions were "of the longest obstiuacy against religion." "Cheeth. Soc., 49 ." 
Anne Sothworth, his daughter.

Dorothie Sothworth, his sister.

John Talbott.

Early in the seventeenth century the religious state of the county is shown by the following extract from a letter

Truly the Papistes in these parts are lately grown so stubborn and contemptnons that in myne opinion it were requisite their Lordships did wryte a verye earnest letter to my very good lord the Earl of Derby, myselfe, and the rest of her Majesty's Commissioners for Causes Ecclesiastical, to keepe some sessions abont Preston, Wigan, and Prescott, where the people are most obstinate and contemptuons, and to deal severely anil roundly with them, other way there can be no reformacon (for the temporal mgstrats will do nothing), nether can the countrye long continue in quiet aud safety.

In the comse of my researches at the British Museum I found the extract given bolow. There can be little doubt that the supposition (as stated in the catalogue) of the late learned librarian, Dr. Bond, that this extract referred to Longridge is erroneous. Dr Boardman hazards the conjecture that it refers to the owners of the manor at Lutterwortl. No date is attached to the original MS.

"Entry-look of the Wigley family".

"Lancaster".

"Precipo Georgio ITunte ct Amue uxor ejus quod inste, etc. Tencant Joluani Hewet concordiam inter eos factam de manerio de Longbridgo duobus messuagiis uno columbario gardino uno orto viginti acris terrac Decu. acris prati quinquaginta acris pasturae tribus acris bosci et quadraginta solidatis redditus cum pertinentiis in Lutworth, et inste, etc."

The following is the return for this district of the "Muster of Soldiers" in 1553:-

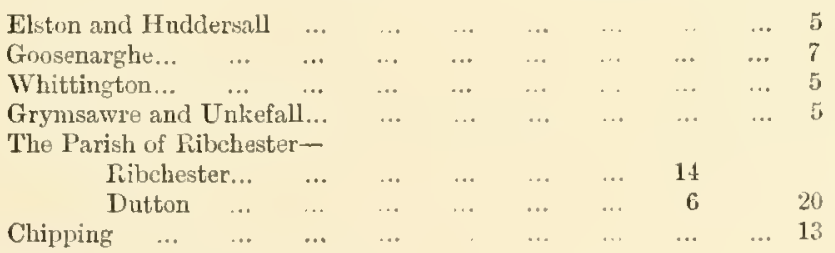

${ }^{1}$ Brit. Mns. Addit. MIS. 6704, f. 41. 
A fifteenth ${ }^{1}$ was levied in 1583 ; the amount due from each place was :-

$\begin{array}{lcccccccccc}\text { Alston-cum-Hothersall } & \ldots & \ldots & \ldots & \ldots & \ldots & \ldots & 14 & 0 \\ \text { Dutton... } & \ldots & \ldots & \ldots & \ldots & \ldots & \ldots & \ldots & \ldots & \mathbf{1 5} & 0 \\ \text { Grimserg-cum-Brockhole } & \ldots & \ldots & \ldots & \ldots & \ldots & \ldots & 10 & 0 \\ \text { Elston } \ldots & \ldots & \ldots & \ldots & \ldots & \ldots & \ldots & \ldots & \ldots & 15 & 8 \\ \text { Goosmargh } & \ldots & \ldots & \ldots & \ldots & \ldots & \ldots & \ldots & \ldots & 46 & 8 \\ \text { Vhittingham... } & \ldots & \ldots & \ldots & \ldots & \ldots & \ldots & \ldots & 27 & 91 \\ \text { Ribchester } & \text { cum-Dilworth } & \ldots & \ldots & \ldots & \ldots & \ldots & \ldots & 35 & 0 \\ \text { Chipping } & \ldots & \ldots & \ldots & \ldots & \ldots & \ldots & \ldots & \ldots & 28 & 0^{2}\end{array}$

We find in 1588 the following gentlemen amoung those returned as having " names of gentlemen of the best callinge whereof choyse is to be made of cten number to lend unto her Matye monye upon privie seals":-

\section{Thomas Whittingham. \\ Mr. Hothersall. \\ Sir John Sothworth. \\ Sir Richard Sherborne. \\ Eiward Osbaldeston. \\ Thurstan Tyldesley. \\ Thomas Singleton. \\ Thomas Houghton.}

In 1601 " a weekly taxation for relief of the married soldiers and prisoners in Marshalsea "3 was ordered to be raised. The following are the local levies:-

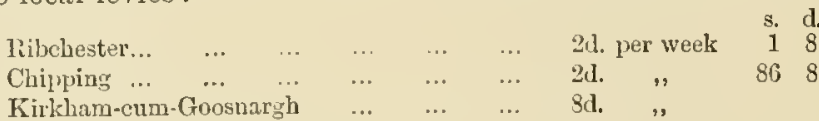

For purposes of comparison the return given below will be useful :Fifteenth-1624.

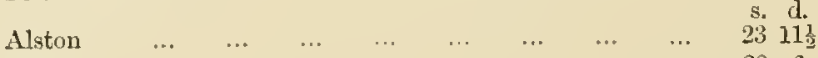

$$
\begin{aligned}
& \begin{array}{lllllllllll}
\text { Elston... } & \ldots & \ldots & \ldots & \ldots & \ldots & \ldots & \ldots & \ldots & 28 & 6
\end{array} \\
& \begin{array}{lllllllllll}
\text { Grimsargh } & \ldots & \ldots & \ldots & \ldots & \ldots & \ldots & \ldots & \ldots & 17 & 11
\end{array} \\
& \begin{array}{lllllllllll}
\text { Goosnarch } & \ldots & \ldots & \ldots & \ldots & \ldots & \ldots & \ldots & \ldots & 79 & 10
\end{array} \\
& \begin{array}{lllllllllll}
\text { Whittington... } & \ldots & \ldots & \ldots & \ldots & \ldots & \ldots & \ldots & 47 & 6 \frac{1}{3}
\end{array} \\
& \begin{array}{lllllllllll}
\text { Chipping } & \ldots & \ldots & \ldots & \ldots & \ldots & \ldots & \ldots & \ldots & 59 & 51
\end{array} \\
& \begin{array}{lllllllll}
\text { libchester and Dilworth ... } & \ldots & \ldots & \ldots & \ldots & \ldots & 74 & 4 \frac{1}{2}
\end{array} \\
& \begin{array}{lllllllllll}
\text { Dutton } & \ldots & \ldots & \ldots & \ldots & \ldots & \ldots & \ldots & \ldots & 31 & 10 \frac{1}{2}
\end{array} \\
& \text { A fifteenth was a very old rate=15th } \quad{ }^{3} \text { Gregson's "Fragments." }
\end{aligned}
$$


In Gregson's map, dated 1598, "Longrilge" and "Langridge Hills" figuro conspicuously.

The Stuarts.

According to a return of the Recusants made in 1613 , taken from the Harl. MSS. in the British Museum, we find it stated that particular mention is made of the number of Recusants ir the parish of Goosnargh; no mention is made of any in Longridge, while the other parishes in this district are returned all together. "A brief abs. of tho Recusants and Non-commenicants retd. Wy the Parsons and Curates, cto., of towns and parishes, etc., in Lancaster, A.D. 1013."

Longridge is thus mentioned by Michael Drayton, the poet, in 1622. In his Polyolbion, published in that year or 10 years before, Drayton, tracing the Ribble's course, thus speaks of Longridge in the quaint fashion then in rogue:-

So Long-ridge ${ }^{1}$, once arrived on the Lancastrian Land,

Salutes me, and with smiles me to his soil invites,

As Hodder that from home attends me from my spring :

Then Calder coming down, from Blackstone Edge doth bring

Me eas'ly on my way to Preston, the great town,

Wherewith my banks are blest: whereat my going down,

Clear Darwen on along me to the sea doth drive,

And in my spacious fall no sooner I arrive,

But Savock ${ }^{2}$ to the north, from Longridge ${ }^{8}$ makiug way,

To this my greatness adels, when in my ample bay.

Leland, who made a tour through Lancashire (1544-50), says :-" A mile without Preston I rode over Savok, a bigge brook, the which rising in the hills a iii or iv miles of on the right hand, not very far of, goeth into Ribel.'

Harrison, chaplain to Lord Cobham, writing in the XVIth century says:- "As for the Sannocke brooke, it riseth somewhat abont Longridge Chappell, goeth to Broughton towne, Cotham Lee Hall, and so into Ribell."

The brook was diverted into the reservoirs belonging to the Preston Corporation.

\footnotetext{
'The reader will notice the byphen in Lon'ridge in the first line, a poetical license which adds force to the pret's argument.
}

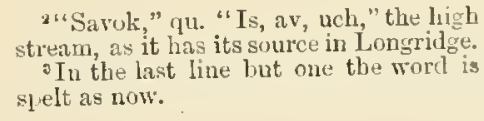

a"Savuk," qu. "Is, av, uch," the ligh strenm, as it has its source in Longridge. - In the last line but one tbe word is sielt as now. 
At this time (1648) the great struggle was raging between the King and the Parliament. Nowhere did it rage more fiercely than on the Lancashire borders. It was at Longridge that Cromwell, who had made forced marches through Yorkshire, came up and engaged the Scots, commanded by Langdale and the Duke of Hamilton.

In a letter to the committee of Lancashire, Cromwoll writes from Preston, 17 Aug., 1648. "It had pleased God this day to show his great power by making his army successful against the common enemy. We lay last night at Mr. Sherburn's, of Stonyhurst, nine $\mathrm{m}^{i 1} \in \mathrm{s}^{1}$ from Preston, which was within three miles of the Scots' quarters." In another letter, dated Aug. 20th, to the Speaker of the House of Commons, Cromwell says - "On the 14th we came to Hodder Bridge over Ribble, " where we held a council of war."

The result of the Council was that Cromwell decided to pass over the river (Hodder), and, as we have seen, halted for the night at Stonyhurst. Very early the next morning (17th) Cromwell marched towards Preston. Captain Hodgson, "the honest-hearted, puddingheaded Yorkshire Puritan "-to use Carlyle's characteristic phraseology - has $1 \mathrm{f}^{\varepsilon_{t}}$ an interesting account of the day's fighting. He says :-

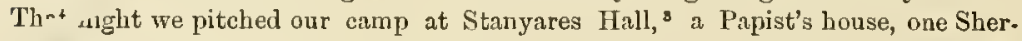
arne ; and the next morving a forlorn was drawn out of horse and foot, and, at - Langridge Chapel, our horse gleaued up a considerable parcel of the enemy, and cought them all the way until within a mile of Preston. They were drawn up very (formidably. One Major l'oundall [ [Pownel] and myself commanded the forlorn of foot; and being drawn up by the moor side (that scattcring being not half the number we should have been), the General [Oliver himself] comes to us, and com. mands us to march. We, not having hilf of onr men come up, desired a little patience. He gives out the word "March," anl so we drew over a little common, where our horse was drawn up, and came to a ditch, and the enemy let fly at us (a company of Langdale's men that was newly raised). They shot at the skies, which did so encourage our men that they wcre willing to venture upon any attempt; aud the Major orders me to march to the next hedge, and I bid him order the men to follow me, and there drew out a smart party ; and we came up to the hedge end,

1Stonyhurst is 12 miles from Preston; lout Cromwell might well make a mistake of this kind, as he had been making furced marches.

${ }^{2}$ What Cromwell meant was Hodder, close by or over arainst the Ribble, and not what he says, which is, of course, absurd.

Stonyhurst.

4Vas the honest Captain indulging in a little sally of wit? 
and the enemy, many of them, threw chown their arms, and run to their party, where was their stuml of pikes, aul a great boly of colours. We irew up towarl them, and on our right band was a party of foot lrawing off, that laid am ambus. cade tu hinder our horse, commanded by Major Smithson, for ${ }^{1}$ pissing up the lane. . . . He (MIajor-General Lumbert) orlererl me to fetch np the Lancashire l"giment, and Gorl brought me off, both horse and uyself. The bullets flew freely; then was the heat of the lnattle that lay. . . . . . The Lancashire foot were as stout men as were in the worhl, and as brave firemen. I liave often told them they were as gool fighters, and as great plunderers as ever vient to a field. It was to admiration to see what a spirit of courage and resolution there was amongst us, an! how God hid us from the fears and dangers we were exposed to ; what posture the enemy were in ; their numbers $(46,000$, as reported); their threateuiags what they wonld do; how they were accoutred and encouraged through the nation. They had cast lots for the spoil of us. ${ }^{2}$

In this battle the Lancashire regiment bore the brunt of the struggle, and soon defeated the Scots with great slaughter, chasing them over Ribbleton Moor and the Ribble as far as Wigan. The number of the Scots slain Cromirell estimated at 1,000, and 4,000 prisoners. His own loss was very little. The Protector's army numbered 10,000 at the most, while Hamilton liad under his command not less than 30,000 men. "Truly it was," as Cromwell exclaimed, "a glorious day," for it was one of the most brilliant victories achieved in the war.

A good many relies of this Battle of Preston, as it is often called, have been found-amougst others, a hidclen treasure, consisting of about 300 silver coins, was discovered, in 1853, in the roof of a thatched cottage at Tenter Hill, Whittingham. ${ }^{3}$ Nearer Preston, at Fulmood and Ribbletou, clear traces of the site of the battle are mentioned by Hardwiek as being visible in 1854 .

I am not aware of any traditions relating to Crommell and the Battle of Preston which bezan at Longridge, except the one already mentioned about the long ridge he found so tiresome to cross. True, it is said that Cronwell slept on the table at Stenyhurst, which he

\footnotetext{
${ }^{1}$ From ?!

FFew, I thiuk, will arree with Carlyle in cunsidering Captitin Hodrsun a "pudling-hearted" man. He war a l,rave and conscientions liepuhlican, ant lossessed of considerahle military skill.
}

3 3ixty-nine of these coins were pre sented by the liev. Mr. Ifossun, of Wodplumutem, to the Avenham Inatitution. 'They' had been minted in the reigns of Mary, Elizabeth, Janes I. and ('harles I. 
found very hard; and that he battered Clitheroe Castle down from the end of Longridge Fell, Kemple End, but it is probable these are only some of the many legendary stories which have attachod themselves to the name of the great Protector. ${ }^{1}$

The Earl of Derby set out, in April, 1643, to put down disaffection in East Lancashire. Moving up the valley of the Ribble, he, "with all the other great Papists in this County, issued out of Preston, and on Wednesday noon [April 19th] came to Ribchester with eleven troops of horse, 700 foot, and infinite of clubmen, in all conceived to be 5,000. From Ribchester he marched, with discretion, over Ribble at Salesbury boat and by Salesbury Hall, and he was well neare gotten to Whaley hefore he was discovered, his clubmen, according to their practice, plundering in most of the tomns they passed by or through. But the Cavaliers were no match for the Roundheads, the result of the expedition being a heavy defeat at Whaley, and were finally driven out of the district by way of Ribchester and Salesbury. This 'affair at Ribchester' would, perlaaps, be more correctly described as the "Battle of Blackburn."

\section{The Protectorate.}

After the suppression of the Chantries, Longridge became the parochial chapelry of a poor district. In 1650 its poverty came forcibly before the Commissioners of the Parliamentary survey iluring the Commonwealth, when it was stated that it lad neither minister nor maintenance, although the district contained 140 families, who, deploring their spiritual destitution, humbly desired tho Legislature to afford them a competent endorment, to appoint a minister, and to constitute their distriet a distinet parish. The sequel to this petition will be found in chapter II.

\footnotetext{
1 One extract from the parish registers of Ribchester ('bur'ch may he given here with Dr. Whittaler's remarks :- "At the Church of Ribchester was interred, in all prolability, the last survivor of all who had borue arms in the war between Charles I. and the l'arliament, for in the parish register is this entry: ' 1736 . Jan. 13, buried William Walker, a
}

cavalier, aged 12\%, de Alston.' This man had a horse killed under him at the battle of Edge IIill. How long he retained his mental faculties I do not know; if nearly to the close of life he must have been a living chronicle extremely interesting and curious." ("History of Richmondshire," ii., 465.) 



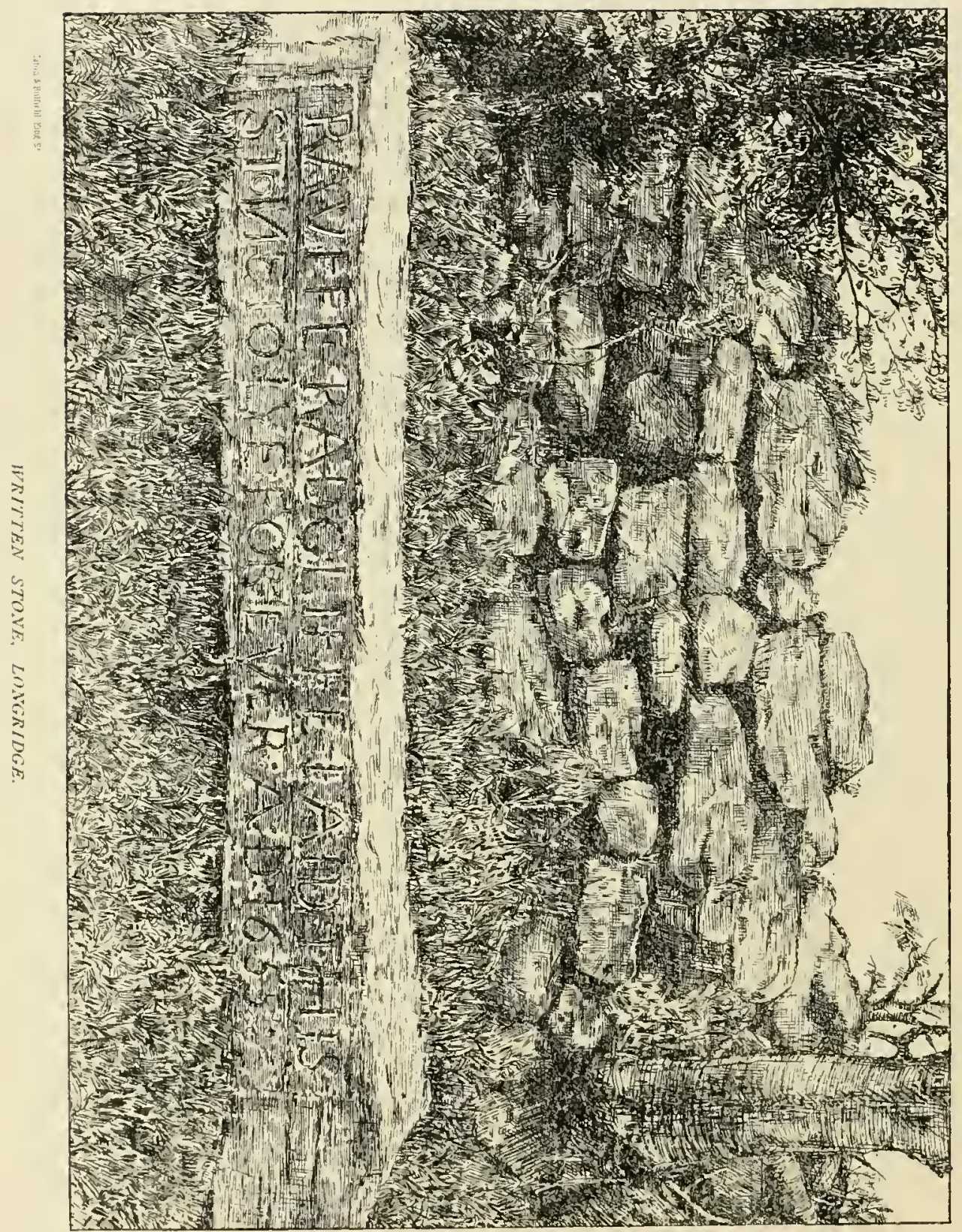


The state of Lancashire during this time (1646-50) was "sad and lamentable." "In this County hath the plargue of pestilence been raging for these three years and upwards, occasioned chiefly by the wars. There is very great scarcity and dearth of all provisions, especially of all sorts of grain, which is fully six-fold the price that of lat9 it hath been. All trade, loy which they have been much supported, is utterly decayed; it would melt any good heart to see the numerons swarms of begging poor, and the many families that pine aray at home, not having faces to beg.' Very many nowe craving almes at other wen's dores, who were used to givo other's almes at their dores-to see paleness, nay, death, appear in the cheeks of the poor, and often to hear of some found dead in their houses, or bighways, for want of bread.". Lancashire continued in an unsettled state until after the rebellion of 1745 , after which year, as is well known, trade, learning, and comfort have flourished to an almost nnexampled extent.

It was shortly after these stirring times (1655), that Ralph Radcliffe laid the stone which is now in Written Stone Lane, Longridge, "to lye" (as he said) "for ever." This stone is in an old Roman private road, called Written Stove Lane, in the township of Dilworth. It can be approached either from the old or new roads to Clitheroe. The best approach is from the old road. Just after passing the Dilworth reservoir, you turn to the right down a narrow lane, and soon find yourself in a deep ravine with often a rapid stream flowing down it, and with tall hedges of hollies on each side. Follom. ing this road for half-a-mile, you turn sharply to the right, and there, at the entrance to a farm-yard, you will find the object of your search. A huge stone about eight feet long, two feet wide, and eighteen inches deep, with the following inscription on it :-

Ravffe Radclifre laid this stone

To lye for ever. A.D. $1655 .^{3}$

\footnotetext{
1 A noteworthy trait in the character of the Lancashire peoplc, as exemplified during the sad tines of the late cottron Famine.

" A true representation of the sarl and lawentable condition of the Conuty of Lancaster." "('heth Ser.," vol. ii.

It is a curious fact that both Baines,
}

in his "History of Lancashire," and Hardwick, in his " History of Preston," give a vruns description (Baines gir tes the correct date) of the inscription on this stone. 'I'bey both render' the legend thus :-

"Rafe liadcliffe laid this stone here to lie for" ever. A.D. 1607." 
The characters are not the raised letters so prevaleut in the sevasteenth century, but decply cut into the stone.

Rafe or Ralph Radclife was a large property owner in the district at this time, and was probably a descendant of that Duke of Lancaster's (John of Gaunt) "dear Squire Thomas de Radclyff," who was one of the Dnke's trustees to lis will on his death in 1399. Why Radcliffe laid this stone I cannot tell, except to commomorate the death of some dear relative, or of Limself. ${ }^{2}$ But, while history is silent upon this point, as about every old and curions thing, so about this stone, mumerous legendary stories are current in the locality, and are more or less believed in by the residents. The date on the stoue speaks of the days of sorcery and witchery. Tradition devlares this spot to have been the scene of a cruel and barbarous murder, and it is stated that this stone was put down in order to appease the restless spirit of the deceased, which played its nightly gambols long after the body had been "hearsed in earih." A capital story is told of one of the former occupants of Written Stone Farm, who, thinking that the stone would make a capital "buttery stone," removed it into the house, and applied it to that use. The result was that the indignant or liberated spirit would never suffer the family to rest. Whatever pots, pans, kettles, or articles of crockery were placed upon the stone were tilted over, their coutents spilled, and the vessels themselves kept up a clattering sound the livelong night at the beck of the unseen spirit. Thus, worried out of his night's rest, the farmer soon found himself compelled to have the stone carefnlly conveyed back to its original resting-place, where it has remained ever since, and the good man's family were never after disturbed by inexplicable nocturnal coises. We!I may they say " ith Hamlet, "Rest, perturbed spirit!"

\footnotetext{
${ }^{1}$ From a careful perusal of the Parish Registers at Ribchester, I find under the heading of "Longridge burials" the following notices:-

Ralph Ratcliffe, Died 26 Feb., 163

Son of ahove lialph, Died 4 Mar., 1654.

WVm. Tiadcliffe, Died 26 May, 1665 .

Wife of John Radcliffe, Died May, 1635 (illegible).

What is more likely than that this stone
}

was laid either to commemorate these deaths following so close upon one another, or that a feeling of superstitious awe may have beeu awakened in the breasts of the survivors of the hereaved family, aud caused them to lay the stone in order to appease the evil spirit that haul coused so much trouble? Certainly it is a curious coincidence, and not, I think, an undesigned one. 
A writer in the "Stonyhmrst Magazine" gives a long and interesting account of his visit to this celebrated stone. "This stone," he says, "is the terror of the neighbourhood. It is said to be haunted!" After relating the "buttery-stone" inciclent, in a somewhat rliffere it mamer to what I have done, he goes on to speak of "an olk man, still said to be living, whose danghter inhabits a farm further up the haunted lane, who was wending his way homeward, late one evening, when close to the stone he saw a female figure which moverl along in front of him; he menderl his pace to see who it was, but in spite of every effort he never gained on it. During the whole time he was very close, but could never clraw closer, and finally his pursuit eucled by the disappearance of its object."

"This was the sprite at play," continues the writer, "but sometimes it was more serious, perhaps in a bad liumour. A local doetor, dead many years ago, was driving down the lane late one night. Passing the stoze, his horse shied and plunged in a state of extreme terror. It then, in spite of bit and rein, galloped forward at a headlong pace, nor was the doetor able to restrain it until ho was a mile or two away from the spot. ${ }^{3}$ As soon as he had succeeded in stopping, he got down to see if it had anything the matter with it. It was corered with blood! It is related of this same doctor, or of another, that he ras one night in a public-house in the vicinity, when the conversation tumed on the Written Stone. He had been drinking freely, and, unmindfnI of his former adventure, wagered that he rould there and then ride to the stone, boasting that he cared nothing for the imp, if indeed such a being existed. Half-an-hour had passed from the moment when he had started, when suddenly he was descried galloping back at a furious speed, but it was not until after the lapse of some time that he gained sufficient courage to relate his adventure. He had ridden boldly up to

${ }^{3}$ Of course these tales wou't bear sifting. Just to give one or two facts, which wiset the "ghost and doctor" story at once. At pach end of the lane there is a gate; at the rest end the distance from the stone to the gate is about 30 yards, while it is 200 yards distant from the east gate.
I am glad to be able to say that for a loug time to come the wish of liadcliffe is likely to be respected. For years and years the old and venerable-looking stone has been an olject of pilyrimage on the part of the penple of the district, and I. trust the owner of the property will never allow the stone to be removed from its present site. 
the stone, when suddenly a shapeless mass appeared, and he was violently seized about the waist and dragged from his saddle, and then so tightly embraced by the monster that he nearly died in the process."

\section{The Stuarts.}

From a document in my possession, dated May 20,1673, the farmers at that time in the township of Alston signed an agreement whereby an equitable division of the highway is made amongst them, each farmer promising to repair a certain portion of the roads, which is duly specified in this document. I subjoin the names of the parties to the agreement, but do not think the whole of the document is worth reprinting. However, a fer of the names of the roads may be given: "Chappell Hill," "Danyill Platt," "The Platt at the Hobbs,"2 "Gunnow Lane End," "Holm Platt," "Booght Fold." s

The signatures are:-

William Hothersall,

H. Shawe,

Richar I Bilsborrow,

John Loyd,

Thomas Gregsou,

George Harrison,

Robt. Willasy,

Will. Dewhurst,

John Walmsley,

Law. Pomerton,

James Lunds,

Thomas Danyill,

Widdow Sudall,

Viculow Dewhurst,

William Bayne,

George Radcliffe,

Ell. Glaytow,

Will. Walmsley,

John Willasy,

John Bleasdale,

George Lirsay,

Thomas Halsall,

Robt. Danyill,

Viddow Ehlds,

Ric. Shuttleworth,

Myles Grunnow,

Rich. Wilkinson,

Will. Cutlow,

Robt. Bleasdale,

Will. Curtis,

Gilbert Bradley,

Widdow Norcross,

Wife of Tho. Sudall, at

Sanderson tenement.

There recently came into my posession a document signed by Charles Hoghton, then Lord of the Manor of Longridga, bearing date 18th July, 1701. It seems that "severall of the most considerable freeholders and others of the inhabitants of this town of Alston had made

1S. M1., Dec., 1857.

The Boot Farm. 
it their request, that I (Charles Hoghton) would allow a cottage to be built upon the waste within my manor of Alston for the conveniency of a poor man, one Thomas Kighley, a Blacksmith." This request was granted by Charles Hoghton most willingly.

The "affair at Preston" in 1715 , does not immediately concer'u this history. But its effects were felt very severely all over Laucashire. "The country was laid under martial law. The luckless insurgents were hunted like wolves amid the neighbouring hills of Preston, and small troops of Hanoverian soldiers were posted throughout the country in bands, and vigorously enforced their presence on the Lancashire peasants, who cherished a faithful devotion to the unfortunate exiles. On the northern slope of Longridge Hill, near Chaighley, one of these barracks was established. It is now in ruins, roofless, dilapidated, and ivy-grown, and is still pointed out as the seat whence the soldiery sallied to harass the lands and humble aboles of the ontlaws." 1

In 1715 the following were returned as non-jurors:DILWORTH.

Lawrence Cottam, geut., leasehold at Ribchester. $\$ 27$. ALaTOX.

Robert Tomlinson, It schold, 10s.

John Duckworth, at Duckett, and Anne, his wife. Estate in her right. Leased to her when Anne Dewhurst

W. IValmsley, yeoman, eldest son of late W. Walmsley. 2 houses and 33 acres, leasehold.

In 1745 a fund was raised in Lancashire "for the purpose of defraying the expenses, and praying a Military Force, in defence of the County from the threatened invasion of the Scottish Rebels."

Alston contributed $\mathcal{E}+1 \mathrm{l1s}$. Od.; the total amount raised in the Cuunty being $£ 16,261$. $^{2}$

The result of the rising of $17+5$ is well known. A high compliment was paid to Preston and its fair ladies at that time by Mr. Kay, the anthor of "A Compleat History of the Rebellion," the ladies being described as beautiful and "very agreeable." This writer also states, that "after I had secured the prisoners before mentioned, I flod across

\footnotetext{
'Stonyhurst Mag., July, 188 j.

a" History of Lancashire Militia."
} 
the country, intending to have gone to Ribchester with the letters, expecting to have been pursued by the robel hussars, but without my knowledge, the gentlemen of Preston had taken care of my safety; by planting a guard upon the bridge . . . . In the evening, I met a countryman, of whom I asked the way, and told him if he met any rebels enquiring after me, to turn them a contrary way, which he pro nised to do. He also toll me it was not safe for me to go to Ribchester, but advised me to go to Clitheroe. Before $\mathbf{I}$ got into the right road, I came to a deep brook, ${ }^{1}$ over which there was a long stone laid for foot travellers, and, in riding over it, one of my horse's hinder feet slippecl. We both fell backward into the water, where I was well dipped, but I and my horse happily got out without receiving any other damage. Having no time to lose, I immodiately mounted, the watcr ruming from my cloatlis, but my boots continued full, and ny firearms were likerrise wet, so that, if I had been pursued, I could liave made little resistance. In this plight I mas in on a cold frosty night, and knew not the road, till I came to a louse, where I hired a guide, who conducted me over Longridge Fell to Clitheroe, where I arrived at ten that night, and had the letters opened by a justice of the peace."

Since 1745 , as I have observed before, Lancashire has shared preeminently in the general prosperity of the country.

The Rev. Fr. Gerrard, of Stonyhurst, has very kindly sent me the following interesting statement about the Mill below Hodkler :-

"Testimony of George Eccles, Miller, Stonyhurst, aged 73 :-

"He remembers an old woman, Ellen Contes, who told him she had worked at this mill. The proprietor was Mrr. Emmett, and he lived in the house which has formed the nucleus of Hodder, and which now is in the centre of its front.

"The mill exteacled from the brook, which runs into the Hodder, ahove the boys' bathing placo (whore there are some cut stone stejs, relics of the old buildings), to below the bathing lince, (where there are some more traces of cut stone work).

i Frobably the Sarok. 
"The hollow, in which the bathing cots stand, was for the mill race, and there was another provision, which I do not quite understand, for surphs water in flood time.

"To raiso the water up to this, there was a Co (I spell phonetically" evidently a dam), from the point still to be seen on the other side, where there is a bit cut out of tho field. I am ratler under the impression that this had something to do with the abore-mentioned overflom.

"The mill moxked on cotton spinning only-no woaving-there would be no power looms in 'them' days.

"The hands were all town aplrentices (nono of the country folk were admitted), and were a dreadful bad lot."

A writer in the Stonyhurst Mtagazine, of Feb., 1887, who signs himself "Uph," says, "that it is well known that near Hodder bridge there existed, about a hundred year's ago, a cotton mill. Both its owners and the people who worked thero, were foreigners to Lancashire; accordingly, both from what they had heard about the new-comers, and from reports of mysterious proceedings at the mill, the country-folk held the strangers in the preatest ablorrence and arre." He goes on to describe what was probably a singular case of contagious lysteria, which occurred among the factory girls, but which was regarded by the people in the locality as a case of demon-possession. He concludes by stating that "the remains of the mill, in the shape of a fer large sized stones, may still be seen at the river, not far below the bathing cots." It was from this apprehension of the wickedness of the mill hands that the people gave to the site of the factory the name of "Hell's Gates," which it long retained.

Since copying the above accomt, I hare seen an old number of the Stonyluerst Mragazine, dated MIay, 1885, which had been mislaid, and in it is an article on "Stony'hurstiana," over the signature 'Ambdus, in which reference is made to this mill. The writer says :-

At the time of the funding of Stonyhnrst as a College by the Jesuits, ${ }^{1}$ there was situated elose to where Holder ${ }^{2}$ now stands, a water-wheel cottou factnry, parts of whose rnins still remain near the old bathing place. This had hecn creeted ly, and was in posession of, a eertain MIr. Eumett, who huilt the old part of the present Hodder House, and lired there.

$\tau_{1194 .}$

${ }^{2}$ Hodiler House. 
Soon after Stouyburst hal heen founderl, the factory and Hodder House came into the market, and were put up for sale. Mr. Thomas Weld, ${ }^{1}$ of Lulworth, hearing that it was in the market, sent a man down to purchase it-one who was unkuown in Lancashire. He dared not attempt to buy it openly, sirce he was a Catholic, ${ }^{2}$ and if lie had publicly bidden for it the bargain would never have been struck. Mr. Weld, having secured possession, ordered the factory to he pulled lown immediately, as it was consilerell to be a place of perfect wickelness, and its pleasant appellation at that time was "Hell Hole."

The writer goes on to describe the difficulties the Society of Jesus met with during their establishment at Stonyhurst. ${ }^{3}$

From a very interestiug articls in the Preston Guardian, of August 15th, 1863, I have obtainer the following information relating to Longridge social customs, and to the Longridge Guild, which is lield annually un St. Lamrence's Day, August 10th :-

"From memoranda in the possession of and in part written by the 'Poet Cuttam,' himself a resident of Lougridgo during the latter part of the last certury, it soems that the usual madrigals composed for the occasion of the 'Gilde' Tere discontinued more than a hundred years before his time." "A part of these remains," says the writer of this article, "were some year's ago placed in my hands by an old native of the village, named Smith, still living, and whose usual cognomen while at Longridge mas "Joe Barry." "

"The first soug of Lungridge Guild is the "Merrie Saung ofe a Cheppender,' in $1698:-$

Ta Langrytch Gil naa lett we hie,

Saide Rogyer, and thay Dick saide yih.

Cottum himsolf wrote as follows:

Now Ceres reigns, the Grod of grain ls dancing in the field;

Here's harvest moon, and sickle soon, So let's to Longridge Guild.

'Thomas Weld, Esq., of Lulworth, was the Lord of Stonyluarst, besides owning extensive estates in Chipping. He was father of Cardinal Weld, the first Englishman that had been so honnured since the Reformation.

${ }^{2}$ Thlese were the days of the odious penal laws against the C'atholics.

SStonyburst does not come within the scope of this work, but, as Hodder House is just outside the Longridge boundary, I thonght an exception might be nade in this case. Most of my reallers are, I have no doubt, well acruainted with the numerous works on this famous school which have heen written-notably Mr. A. Hewitson's able book. MIay I add that the reneral reader will find the Stonyhurst Magazine to be far above the average of school magazines. 
"The festival had rloubtless its origin in Catholie times, when the poor were regularly fed and maintained ont of the revenue of the monastery. Wo think it is Butler, himsolf a Catholic writer, who throws some light on the origin of these aneient institutions. It was customary in those days, in addition to feeding the hungry and destitute daily, to give them a sort of a jubilee annually, on the anniversary of the Patron Saint.

"It is customary for the various sehools and Friendly Societies to walk in procession through the streets on the Guild day. ${ }^{1}$ Many showmen and itinerary vendors tur'u up here also, and the day is altogether given over to merry-making. Usually, large numbers of visitors from all the country side floek to the town on the Guild day.

"For" a eentury and a lialf things remained in the village all but stationary. An old gentleman, aged nearly 90, who has lived there all his life, informed the writer that when he was a boy (1760) broadcloth was in the neighbourhood all but unknown. Tho dress worn by men was a kind of serge or corduroy; while the means of loeomotion were of the rudest description. The farmers, in conveying their produce from one place to another, used a clumsy, heavy sort of cart with two wheels, but the wheels were fastened to the axle tree, which went round aloug witlı the wlieels.

"Many of the habits and eustoms of the people were equally primitive. The ratepayers met once a fortnight, often seldomer, to hear and consider the fer eases of poor persous who applied to them. At least ten out of every dozen adults in the village kuew as much about those meetings, or the business transacted there, as they knew about 'the man in the moon.' The apples of the Hespericles were not more jealously guarded than were the secrets of 'Town's Meetings' in those days; and when every elass of intellect, every sort of administrative ability had tried to reform the abuses existing, another Hercules at last turned up, in the person of Lord Althorpe, who boldly entered the enclosure, and earried off the fruit.

\footnotetext{
13r. Hoole, who was school. master at Lungridge from $18: 0$ to 1857 , remembers the time when there were no processions on the fruild day; horse
}

racing (prize, a saddle) - the course being from the Dog Inn to the Quarry. man's Arms - was the great attraction in the streets at that time (1815). 
"These town's meatings were confined to about half-a-doze z farmer's, with the clergyman or some country yeoman for chairman, and the discussions which took place at them were of a more serious character when directed to the Surveyor's salary, or the premium to be paid to the Molecateher. Their records, precious as they were, have, as a rule, been sold for waste paper, and may bo met with as covers for candles, soap, and such articles as the grocer sells.

"There is a eurions specimen relating to the "Town's Meeting and Vestry of Alston' :-

$$
\text { 627 July, } 1782 .
$$

'Pade to George Cluff for kepin Lundon Jak (an inmate of the poorhouse, fro distorbin t' kongrgation at chappel, 7 pence, for being craz'd.-(Signed) J. S.'

"Then there is a strange document which runs thus:-

'Boot Farm, Aug. 4, 1790.

'Thiss is to sartisefy that Nickls Billinton hes kilt 8 MLols and 2 foomards (pole cats) e aer gret medda, tuppus o peese is one and 8d., o calse o bred and cuert wey 3 hopns, meks 2 shillin bod a hopiny. Iou mon pay to neet.-R. Wilkinson.'

"The next is an account for work done in the poorhouse, by an inmate who must have been well off :-

$$
\text { ‘ } 27 \text { Nor., } 1790 .
$$

'Pade Joonus Boothe, wey'vin 4 cutts (pieces of cloth) at 6 shillin, one pound 4.-H. Eccles.'

"There is another little note, which shall conclude the series. It relates to the germ of sanitary improvements, then, however, not dreamt of :-

'Mistress Langdon,-Your Pig's cont runs reight under Bettys windor, in Kester lane brow. It stinks in Betty's nose worse than a Pow (Pole) Cat. You must remov it, or you, Mistress Langdon. From sours, C. N.'"

In 1796, there died, at Longridge, aged 86, Mr. John Wharton, formerly carrier between York and Preston. 
The following is a copy of a Doctor's bill dated 1796 :-

Ringer Fleming, Overseer of Alston,

To Benjn Abbatt, Dr.

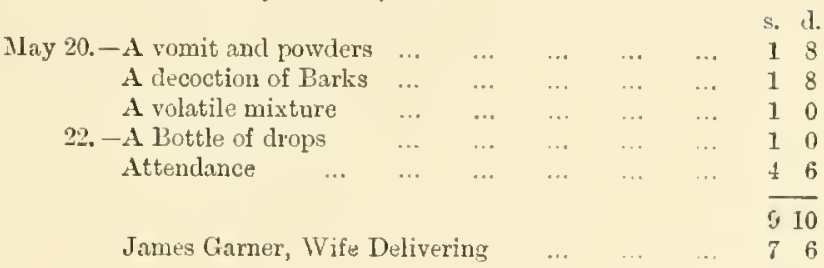

£0 $17 \quad 4$

The following letters from an cld Lougridge resident are pathetic in the extreme. They are addressed from Chester to the Overseer of the Poor at Alston :-

S April, 1799.-This is to signify that old Mary Thrope is still living, and it cannot be expected that her condition is any bettered by the severe season she has weathered throngh, but, on the contrary, much worse, for she is almost starved and hungered to death. It seems strange that her poor pittance, when it becomes due, can never be sent without so mnch trouble in writing : pray send it her by the first conveyance, and be assured if anything shall happen to her you shall be informed.

W. Richardson.

July $20,1500 .-$ I have once more taken the liberty of repeating in a hrief manner my necessity and extreme want whieh to a heart possessed of humanity needs not the least apology-and may be easier imagined than described. You are not insensible of the great scarcity and dearness of every necessary of life, which every one in a greater or lesser degree must feel. Judge then my situation at this time, being almost naked for clothes, and destitute of money or friends, or any other means to help myself in this distress. Therefore I humbly hope you will be kind enough to let me have what has been usually allowed, and so long withheld from me; and let me have some little clothing, which I am in absolute want of ; and I hmmbly hope and pray you will not defer any longer to contribute what is so necessary for me as speody as you conveniently can.

Mary Throup.

Let us hope poor Mary's letter was answered as she desired!

It is, I believe, clearly proved by the returns of the Registrar General that illegitimaey is more rife in Lancashire than in almost any other county. 
The following document speaks for itself :-

Thos. Bauks.

\begin{tabular}{|c|c|c|c|c|c|c|c|}
\hline 1826, Feb. 11. & o Bastardy & $\ldots$ & $\ldots$ & $\ldots$ & $\ldots$ & $\ldots$ & 8140 \\
\hline 1827 do. & Do. & $\ldots$ & $\ldots$ & $\ldots$ & .. & $\ldots$ & 54 \\
\hline 1528 & Do. & ... & $\ldots$ & $\cdots$ & $\ldots$ & $\ldots$ & 54 \\
\hline 1829 do. & Do. & ... & $\ldots$ & $\ldots$ & $\ldots$ & ... & 54 \\
\hline 1829, Dec. 31. & Do. & ... & $\ldots$ & $\ldots$ & $\ldots$ & $\ldots$ & 4120 \\
\hline
\end{tabular}

This is a somewhat clelicate-some would say "improper"-subject to write about. But as John Stuart Mills says, somewhere, "diseases of a moral nature should be plainly discussed in the same way as bodily complaints."

The county of Banffshire seems to share with the county of Lancaster in the unenviable position of a high illegitimate birth-rate. Mr. Cramond, of Cullen, shows that 30 years ago the illegitimate births in Banffshire were 16 per cent., and that they are 16 per cent. still. Sixty years ago the illegitimate births in Alston wero 33 per cent. To-rlay they are only 5 per cent. We think a great responsibility rests on the clergymen of all denominations and other teachers of the people in this district for the lack of moral courage in not spealying out plainly on this subject. The low tone of morality prevalent on this subject, the overcrowding in the homes of the people, ${ }^{2}$ the waut of interest shown by employers in the welfare of their servants are the causes to-day, as they were 60 years ago, of the high illegitimate birth rate. Theu the clergy, landowners, and cmployers were responsible for the evil. Now the people themselves have the remedy to a large extent in their own hands. It will he their own fault if the causes which are so hostile to their moral progress continue to exist.

\footnotetext{
'It is notorious that it was a fairly general custom for engaged couples annongst the working classes in this district to wait until just before or just after the birth of their first child hefore going through the form of marriage.

${ }^{2}$ Sureiy it is only necessary to state the following fact to ensure its condem-
}

nation as scandalous:-Over one-half of the houses in Longridge are provided with no more than two bedrooms. Land is cheap, and rates are high ; the moral and sanitary condition of the people is apparently only a secondar'y consideration. 
Down to the Catholic Emancipation Act, the Roman Catholics, or "Papists," as they were commonly termod at the time, were liable to a double assessment on their rates, because of their non-conforming to the Test Acts of Willinm and Mary. In the accounts for Alston in 1749, the following interesting statement occurs:- "Protostaut Equal Assessment is $£ 1712 \mathrm{~s} .11 \mathrm{l}$. The Papist Donble Assessment is £24 2s." But, in 1787, a case had been stated for the opinion of Edward Law, Esq., a Barrister of the Inner Temple, as to the legality of this mode of assessment. In his opinion, Mr. Law emphatically declares that this double assessment of non-conforming Papists is Iegal.

There seems to have been a good deal of ill-feeling between the rulers of Longridge in the eighteenth century and their brethreu at Ribchester. Details of the expenses of certain "Tryalls" are preserver. Theso disputes appear to have been chiefly about roads. In 1748-49 the bill came to $£ 23 \mathrm{~s} .2$ d. Mr. Starkey was the legal adviser of t'se "Meu of Alston."

In 1813 a dispute took place as to who ought to repair the road from the White Bull in Alston to the Ribble. One lawyer's bill was for $£ 1215$ s., while another came to $£ 79 \mathrm{~s} .2 \mathrm{~d}$., and the litigious " $\mathrm{Yeu}$ of Alston" lost the case.

Some of the entries in the minute book of the "Seloct Vestry" of Alston are very curious reading. For example, contrast the following: applications for relief and the auswer's thereto:-

"Aug. 31st, 1820.-William Windle, of Alston, wants one ponnd to enable him to become a hawker." Reply-"Agreed to lend him one pound, to be repaid at such time as the Committee think proper."

"Aug. 17th, 1820.-William Almoud, of Dilworth, wants something to carry his wife to the salt water." Reply-" Nothing granted."

Frequent applications were made for "shifts" aud clothing, which were generally left to the officer's to deal with.

On Nov. 21st, 1822, Mr. W. Buck, who seems to have often acted as chairman, proposed a resolution, which was unanimously carriel, that Alston-with-Hothersall should, if possible, be made into separate townships. The following entry is often found :- "A regular meeting was held this day, and no paupers attended." 
The "Select Vestry" for 1820-1825 seems to have been composed of William Buck, Rev. Robert Parkinson, Ric. Shuttleworth, Seth Eceles, senr., David Nuttall, Edmund Eastham, Oliver Hothersall, Heury Parkinson, W. Clough, Wm. Walne, James Pye, and Richard Moss.

The earliest books or papers belonging to the "Select Vestry" of Dilworth to not appear to have been preserved prior to Sept. 12th, 1845 , as at a meeting held on that date it mas ordered that "a book should be purchased by the Surveyor to make entries into of this and all future meetings."

The members from 1845 to 1860 were-

$\begin{array}{ll}\text { Wm. Bourue, } & \text { Thurstan Greenall, } \\ \text { Wm. Marsden, } & \text { John Seed, } \\ \text { Wm. Skilbeck, } & \text { John Jump, } \\ \text { Iid. Parkiuson, } & \text { Thos. Spencer, } \\ \text { Fid. Dixon, } & \text { Will. Dixon, } \\ \text { Charles Foster, } & \text { Wn. Bond, } \\ \text { Wm. Banks, } & \text { Fohert Smith. }\end{array}$

Mrs. Fanny Eccles, one of the oldest inhabitants of Longridge, has cnabled me to give the following account of the building of Longridge, and of some of the interesting manners and customs of the people during the latter part of the last, and early part of the present, century.

Prier to 1800 , Longridge was but a mere hamlet, containing a few scattered cottages and a couple or se of inns. The greater pertion of the land on the northern aud north-western side of the fell was moorland aud unenclosed. In $1804 \mathrm{King}$ Street was built; the old Club Row having been built a few years before. An old cottage in Fell Brow for years went by the high-sounding name of "The Tomn's Hall," and was the property of the late Rev. R. Parkinson, Curate of Lougridge. Mr. Wur. Buck emner a good deal of property at that time, and was much belered by the people. Lime used to be carried in large quantities in panniers on mules' backs. A thriving industry was the besom trade. They were carted from Longridge to Liverpool ; and the carrier used to load back with spirits. Two days were set apart for the annual Guild-on one day was the horse-race, and a foot race was lield on the sccond day. 
The announcements of public sales were made by the Clerk on Sundays just after service at the ehureh gates. In addition to their ehureh duties, the ehureldwardens used to visit the public-houses on Sundays in order to detoet illicit drinking. Any publieans eaught were fined by them for "chapel breaking," as it was ealled. At one time, abont $1825-30$, so well off were the handloom weavers that they frequently lit their pipes with 20s. notes. It was no uneommon thing for a female weaver to weave three $20 \mathrm{~s}$. "cuts" in a fortnight. People in those days drossed in a lomely and commou-sense fashion, or to use Mrs. Eceles's expressive phrase, "Their Suuday elothes were not so fine as these people wear now-a-days on Saturdays." Alas! for the "good old times."

The Village stocks used to be placed in the S.E. portion of the ehureh-yard. Drunkaris were principally the people who were made to patronize them.

We may achl that Mrs. Eccles, who is 72 years of age, is exceedingly intelligent and has a wonderful mexory. The changes she has witnessed iu her native pixce are such as are seldom rouchsafed to any one person. A daughter of the late Mr. WWm. Banks, she lived for many years at the Black Bull Inn, ${ }^{1}$ Longridge, and now resides at her own house in King Street, along with her daughter and son-in-law, MIr. and Mrs. Thos. Duckworth.

In appendix $A$ will be found a copy of a brief issued in 1826 for a collection towards the relief of William Strieklaud, Richard Pinder, John Bennett, and William Bennett, whose bobbin and wood-turning: works, at Dilworth Bottoms, were completely destroyed by fire on January 12th, 1825. The loss sustained was estimated at $£ 34817 \mathrm{~s} .4 \mathrm{~d}$. Collections were asked for on the owners' behalf in Berriek-uponTweed, Co's. Flint, Denbigh, and Radnor, and house to house colleetions throughout the counties Palatine of Lancaster and Chester. I understand that this amount was not raised; but I have been unable to ascertain what sum was eollected.

${ }^{1}$ Now the Corporation Arms. 
In 1829, the County of Lancaster seems to have been taken with a puritanical fit. An official notice, signed by William Lawn, and Peter Hesketh, two Justices of the Peace, was given to "the Constables, Churchwardens, and Overseers of the Poor" of Alston, that they should strictly and diligently search and apprehend all persons practising "Leaping, Playing at Foot-Ball, Quoits, Bowls, and many other unlanful games; Hunting, Tippling in the Ale-Houses, Swearing, Cursing, Profaning the Sabbath, and absenting themselves in time of Divine Service from the Church on the Lord's Day." Any persons guilty of such conduct were rendered liable to the penalty of "Three Sillings and Fourpence, for the use of the poor in the Tornship where such offences are committed, or sit in the Stocks for the space of three hours."

In 1831, the quota apportioned to the tomnslip of Alston was three men to serre in the militia.

The Preston and Longridge Railway was opened for traffic in May, 1840. At first it was worked by horses, and as the line is on a steep incline all the way, the horses, after drawing the trains to Longridge used to ride down in the ran on the return jounneys. In 1848 the first locomotive was used. The serrice of trains was as follows: Sunday, Monday, Wednesclay, and Saturday, two trains a day.

The return fare (third class) was 9 d.-less than it is now!

The line ras originally intended to be continued through Ribchester and Hurst Green to Yorkshire, but owing to the determined opposition of some of the then leading landowners in the district, the scheme was abandoned. It was a well-matured scheme, and it is a pity that such a splendid opportunity of developing this part of Lancashire should have failed through short-sighted opposition.

A rery useful invention for "curbing the screws" to tighten the metals was made by the late $\mathrm{M}[\mathrm{r}$. WWm. Banks. Before his invention the price charged for "curbing" was from 8s. to 4s., whereas Mr.

\footnotetext{
${ }^{1}$ This local legislation is almost on a par with certain specimens of New England Puritanic legislation in force about 1630. "If ary man shall kiss his wife, or wife her husband, on the Lord's Day, the party in fault shall be purished at
}

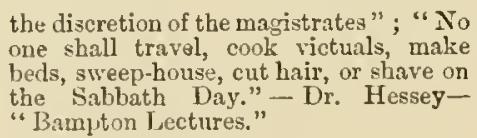
one shall travel, cook victuals, make beds, sweep-house, cut hair, or shave on the Sabbath Day." - Dr. Hessey"Bampton Lectures." 
Banks contracted for the work on the Lomgridge line at $2 \mathrm{~s}$. a metal. Notwithstanding the great reuluction in price, M[r. Banks was able to make as much as $£ 8$ a day. Within twelve months his plan was in use on all the railway lines in the Kingdom; and his "patent" was sold for only $£ 5$.

Un Ang. 10th, 1867, a serious acciclent occurred. A special train left Longridge shortly after the ordinary 7-30 p.m. train, and, near Fultrood, through some blundering, the special ran into the leading train. A terrible scene followed. Both trains were crowded with visitors returning from the Guild festivities at Longriclge. Over sixty persons were injured, several seriously. Strange to say no news of the acciclent reached Longridge until the following morning. Many hundreds of the visitors remained in the vicinity of the station waiting for the retmu of the train; and numbers had to sleep out of doors amid scenes of indescribable confusion.

From such works as Bamford's "Radical ;" Waugh's "Lancashire Sketches;" Dr. Cooke-Taylor's "Notes of a Tour through Laneashire;" and the Press of the period, it appears that the state of the people in the cotton manufacturing districts of Lancashire was pitiable in the extreme, from 1830 to 1850 . Handloom weavers were out of work for months, going up and down beggiug for a job of any kind to get a bit of bread with. Thero was hardly any parish relief to be had, and starration and misery were ouly too often tho lot of the poor people. Nor was the Longridge stone trade much better at that time. The cause of this sad state of things is apparent at once. The cotton trade was in a state of transition; the powcr-loom was superseding the handloom in all directions; and in the interregunm which necessarily prevailed, the workpeople had to suffer. How much this state of things affected Longridge is proved by the retrograde position of the population. In 1831 the population of Longridge was 1,917 ; in 1841 it was only 1,904 , a decrease of 13 in 10 years, while in the next decade the population had clwindled domn to 1,821 .

But for the development of the stune trade, there can be little doubt that the village of Longridge would have remained in the same stationary condition as such places as Chipping, Goosuargh, aud Rib- 
chester. It was not until 1830 that a quarry, or delph, on any large scale was opened out in Longridge. Peter Walkdeu in his diary (1729) refers to Jack Singleton o' th' Delph, but Mr. Fleming was the first max who made Longridge free-stone known outside the rillage itself. Under such men as Fleming, Fletcher, and Speucer the stone trade was largely developed. The quarrying appliances used in those days were, of course, very primitive.

Messrs. Cooper and Tullis, the eminent contractors, of Preston, became in 1856 (having taken Chapel Hill in 1850) the tenants of Spencer's quarry. Stone from their quarries was used for such works as Bolton Parish Church, Preston Station, St. Walburge's Church, and the Prestou Free Library, etc. For some years Messrs. Banks Bros. worked one of the quarries. In 1863 Messrs. Waring Bros. commenced working' Fleming's quarry, and Nook Fold, which they now oceipy. In $1874 \mathrm{Mr}$. Robert Smith opened the Broom Hill Quarry, part of which had been previously worked by Mr. Kenyon. He was one of the first to use steam cranes and travellers, Messrs. Cooper and Tullis liaving used them a fer months previously. The quarry was, however, soon closed; it is now worked by Mr. Geo. Banks. All these quarries are situated on what is called the Tootal Height estate.

Some very good stone has for a number of years been obtained from the Chapel Hill Quarries, one of which has been worked for a uumber of years by Mr. John Sharples, who still works it. A fow years ago Messrs. Kay and Pinder, contractors, opened out another quarry in this locality.

The present state of the Longridge stone trade is not at all good. Only about 100 men are employed altogether in the trade. Ten years ago 400 men were employed. The causes of the bad trade seem to be the keen competition from Yorkshire and Wales, and the prohibitory rates charged by the Railway Co. for carriage. In this matter, and other things, the owners of the Preston and Iongridge Railway have displayed a poor conception of their duties as a carrying company. Of course there is no competition, and, like Corporations, Railray Companies bave prorerbially no conscience. 
During a very quiet period, Longridge was suddenly thrown into a state of excitement by the arrival of a battalion of soldiers, who came to encamp there during the Crimean War, in 1854-55. Their tents were pitched close to Forty-acres, a farm near Jeffrey Hill. Their conduct during their stay at Longridge was not as exemplary as it might have been, and the people, who had relcomed them heartily on their arrival, were not sorry when they departed.

The first time a flag was ever known to he erected on Tootal Height, was at the proclamation of pence after tho Crimean War. In 1862, (n) the occasion of the marriage of the Prince and Princess of Wales, a huge bonfire was kindled on the same well-known eminence, chiefly through the exertions of Messrs. Cooper and Tullis.

On Norember 1ith, 1862, one of the happily solitnry trigedies that have taken place in this district, was perpetrated at a small beerhouse adjoining the high road from Longridge to Ribchester. Mrs. Ann Walne, a widow 79 years of age, who resided alone, was murdered under most horrible circumstances. She ras of rather eccentric and penurious habits, and an impression prevailed in the locality that she was possessed of menns, and generally kept a sum of money by her in the house. On the morning of Tuesday, Nov. 11th, a man ment to her honse for the purpose of foddering the cows. After knocking for some time at the house door, without awakening the old woman, he proceeded to the rear of the house, and, finding that a window lad been torn from its place, he went for assistance. Accompranied by a neighbouring farmer, the man entered the honse, and found Mrs. Walne lying dead upon her bed, with one hand tied to each of the posts of the bed, with her face and temples dreadfully bruised, with a handkerchief stuffed tightly into her mouth, and her lower limbs denuded of clothing; the bedding heing much disarranged, shuwing that a fearful struggle had taken place. After sume time, Daniel Carr, George WVoods, William WVools, Dunean McPhail, and Benjamin Hartley, were arrested, when the latter tumed approver. Fruin Hartley's evilence, robbery was the motive of the murler, but William Woods was not among the murderers. Accordingly he was released, and Duncan McPlail, Daniel Carr, and George Woods mere 
committed to the assizes on the charge of wilful murder. Carr died suddenly on the morning of the trial; so that only McPhail and Woods were tried before Mr. Baron Martin, on 30th Mareh, 1863, and were both condemned to death. Unavailing efforts were made to obtain a commutation of the sentence, and McPhail and Woods were hanged at Kirkdale on April 25th, 1863.

Longridge was the scene of disorder during the memorable lock-out of 1878. On May 16th, a rude effigy of Mr. Henry Waring, Chairman of the Lougridge Manufacturing Co., was burnt at the rear of King Street, amid the yells and cries of a large but good humoured mob. About nine o'clock the same evening, an attempt was made to hustle Mr. Robert Smith, of Victoria Mill, but the police prevented it. My father, however, employed a large number of private watehers to guard his house (it was the week after Colonel R. R. Jackson's house, about 6 miles off, had been burnt down), and I shall not forget the anxiety I folt as I lay awake at night, listening to the steady tramp of the "special constables." We were in fear, not so much of the Longridge people as of the Blackburn rioters, and so real was the fenr that a troop of clragoous was in readiness to march on Longridge from Preston.

A good deal of distress was experienced by the operatives, aud relief was given by the Vicar aud some of the employers of labour. Eventually, after a struggle lasting two months, the operatives submitted to the reduction of 10 per cent. No trade disputes of any magnitude have taken place in Longrilge since 1878.

The Jubilee of Her Gracious Majesty the Queen was celebrated in much the same fashion at Longridge as elsewhere. Eating aud drinking and walking in procession are apparently the orthodox modes in which an Englishmau takes his pleasure. A dinner to the people ovor 50 years of age was given to about 500 people, by Mr. Robert Smith, J.P., at his residence, and Messrs. Wariug Brothers gave their workmen and their wives a supper. Tea parties innumerable were held, and jubilee medals blazed on the breasts of the loyal people of Longridge. Not a very happy or very sensible way of commemorating an almost unique National Erent, will be the verdict 
of the Historian of the future. How much better, one is tempted to say, would it have been to have founded a free library, or to have established a public play ground? The prettiest sight, and one which stirred the hearts of those who saw it, was the sight of the beacon fres, which from almost every hill top in the kingdom lit up the heavons. On Parlick Pike, on Beacon Fell, on the heights of Hoghton, and on Old Pendle, and on many a lesser eminence, the fires blazed all night through, reminding one of the days of "The Spanish Fright," or "The Pilgrimage of Grace," when they were of the utmost service to those who knew only too well what they meant.

One memorial of the Jubilee which will, neelless to say, outlast the ones I have mentioned, was erected by a woll-known resident of Longridge, whose identity, as "the Owner of Well brow," will be easily recognised. The memorial took the shape of two huge stones, which serve as seats for the tired pedestrian, with the legend "1887" cut on the face of each.

The roasting of a whole ox is such an uncommon event now-a-days that the fact of one being roasted at Longridge during the Jubilee year deserves to be placed on record. Mruch excitement was created by the event, and an enormous crowd gathered to watch the cuttingup, as well as to taste the meat. The head of tho ox, a fino black Galloway, bred at Well Brow farm, was mounted, as were also the hoofs. 


\section{CHAPTER II-ECCLESIASTICAL HISTORY.}

William Hothersall, founder of Parish C'hurch -Church Ornaments and Bells, 155 Neither MTinister nor Endowment, 1650-Act of Uniformity-C. Hindle and Ingham-Expenses at Chappell, 1685-No Registers before 1760-Church rebuilt, 1716, 1784, 1822 - Living augmenter, 1756-The Old Bazoon, 1794-Value of living, 1834-Tower built, 1841-Account of frustrated attempt to build a $\mathrm{New}$ Church, 1873-Increase of Non-Church Goers-St. Paul's Church-Enormons cost -List of Subscribers Rushes on flnor, 1837- "Old Bob Booth and the "bassoon " -Church in 1872, as described by "Atticus"-Changes in Church-yard-Uncom. fortable Pews - Poor Chancel-Coloured "IVindows"-- "Lion and Unicorn" painting-Wretched Singing - MIovalble Seats-The Font-Value of living, 1888-

Nemorandum by J. H. Longworth-Purchase of Tithes-Church Schools-Old Boys' School-Vicars of Longridge, 1554, Sir Robert Cottom- "No Typler nor Dyce Man " - Curate of Preston and his Vicar-161-Mr. Harley - "Scandalous in Life and Conversation "-165, Timothy Smith-Ejected, 1662-Memorial of himList of "Conformists" and "Nonconformists"-Mr. J. R. Green on the Act of Uniformity-1701, Thos. Felgate-1730, Richard Dixon-1743, John Sharpe -17S0, Robert Parkinson: Canon Parkinson's Criticism-Memolial-1829, George Tarkin's sudden death-Nemorial-1831, Erederiok Mande: Memorial-1843, Edward Pigot, Rector of Whittingham--1817. IV. C. Bache: Criticism by "Atticus"-Presentation-Vicar of Alresford-Miss Bache-1877, F. A. Cave Browne-Cave: "fine English gentleman"-Energetic work-Non-religious workSocial exclusiveness of people - Epitaph on "one Cave" - Pedigree of CaveBrowne-Cave family-Roman Catholio Church-List of Priests-H. Brown-S. Clarkson-T. Davis - Charles Boardman-Old brass cross-New Church npener by Bishop of Salford--Beautiful Interinr-Good Singing-Rev, C Boardman: Literary abilities-Library-Engravings-Public Work-Alston Lane Catholic ChurchList of Priests-H. Sharples - Thos. Walton-Independent Church-Its OriginDescription by "Atticus"-Good Singing-W. Booth-G. Price-H. ArchibaldWesleyan Church - "Mlount Zion"-Particular Baptists-Knowle Green Church - IV. Hayhurst-Giles Scott, "Bishop of Knowle Green"-Gond WorkTiesignation.

Ecclesiastical erents occupy a prominent place in the history of Longridge.

Canon Raines, in his "History of the Lancashire Chantries," says that both the name of the founder of Longridge Church (dedicated to St. Lamrence) and the date of its erection are uncertain. $\mathrm{H}_{\Theta}$ hazards the suggestion that William Hothersall, of Hothersall, was the founder; but merely says the date of its erection is uncertain. ${ }^{1}$ $W_{e}$ sliall therefore probably never linow more of the early history of Longridge Church than the very meagre account we now possess.

When the spoliation of the Chantries took place in the reign of Henry TIII. and Edrard VI. the bells, chalices, and ornaments were gener:illy given up; but at many places the bells at least were kept back. Ac-

${ }^{1}$ Inst certainly long hefore the Reformation. 
coruingly in the 1st year of the reign of Queen Mary, 1554, a Royal Commission was appointed "to enquire, serebe, and survey what land and tenements and hereditaments, and bell and ehalisses, plate, jerrell, and stockes of Kyen shepe, mony, and other things," which had not been surrendered to King Edward VI.'s Commissioners.

Edward Parker, whe was appointed Sub-Commissioner by the former Commission, declared that he had not received certain bells, amongst which was, "item, one lytell bell belongyug to the chapell of Longerydche." For we find that "Syr Rout. Cottom, priest, and John Tomlynson, chyrche reve, sworn and examined, depose and say, "that there $y$ s one belle yett remayninge at $y^{\prime} \theta$ said chapell specifyed in ye said sedule wch was lease to thuse of our said late soveraigne lorde Kinge Edwarde ye vjth, by anetorytie of ye sail former Comyssion.'" The chaliee, of silver gilt, weighing $7 \frac{3}{4}$ ounces was given up, as were also the ornaments, which were valned at twelvepence.

In 1650 the Jurors of the Inquisition say "that the said parishe (Ribchester) doth contayne within it fomre Townshippes, viz., Alstoncum-Hothersall, being distant from their Parishe Church five myles, ${ }^{2}$ Dilworth, foure myles, and Dutton, foure myles. And they further saye that there is one chappell within the said Parishe, viz., Longridge Chapell, standinge in Alston aforesaid, and distant from their Parish Church betwixt foare and five myles, ${ }^{2}$ but neither Minister nor mayntenanee. The inhabitants of Alsten-emm-Hothersall and Dilworth, being remeate from their Parishe Churel, as aforesaid, and consistinge of one hundred and fforty families, humbly desire the same may be made a Purishe Church, and that the minister and competent mayntenance may be allowed." (Lambeth MS. Survey of Chureh Lands, vol. xi.)

After the suppression of the chantries, Longridge treeame the parechial chapelry of a poor district. In 1650 its poverty came foreitly before the Commissioners of the Parliamentary Survey, when it was stated

\footnotetext{
Notice the spelling. One other variation we find about this time, Longrigg.

This is inaccurate, the Parish rhurch of Longridge being distant $3 \frac{1}{2}$ miles only
}

from Ribchester Church. But this exagreration of distances, etc., is an uld trick for supporting arguments and one not confined to the grood old times. 
that it had neither minister nor maintenance (see above), although the district contained 140 families, who, deploring their episcopal destitution, humbly desired the legislature to afford them a competent endowment to appoint a minister and to constitute their district a distinct parish.

Canon Raines comments upon the petition as follows:- "It is to be regretted that so discreet and reasonable petition was not granted." A minister was, however, soon afterwards appointed in the person of Timothy Smith. The Rev. Timothy Smith was a brave and conscientious man, very unlike the man Ingham, who at this time was applying for Longridge, or pretending to do so (see below), for when he was called on to "declare his unfeigned assent and consent" to the Book of Common Prayer in conformity with the Act of Uniformity he refused to do so, and was ejected from his charge. He, however, often preached in his chapel after this, probably because, as Calamy remarks, "Longridge was an obscure place with a small salary."

An attempt was made in 1651 to get rid of Christopher Hindle, a highly-educated man, who had been a long time Vicar of Ribchester. The following 1) lan was adopted:- "One Ingham, a highly-gifted man of that time, produeed a recommendation from the parishioners in order to his obtaining the euracy of Longrilge, in this parish, but during the conveyance had the address and honesty to alter it into a petition for the vicarage itself, in consequence of which he obtained an order from the committee of plundered ministers to dispossess the lawful incumbent, and enter upon the benefice himself. Mr Hindle, howerer, was a man of spirit, and would not give up the pulpit withont a struggle, during which Ingham intruded himself into it. Mr. Mindle, then standing upon the highest step in the presence of sereral Parliament soldiers who were there to induct Ingham, made a bold and pathetic appeal to the congregation. He described the wretehed confusion which prevailed both in Church and State, charged the ruin of hoth upon the rebels, represented the then recent murder of the King in the blackest colours, and coneluded with a charitable prayer for the conversion of all who were involved in these horrid erimes. In revenge for this noble conduct he was apprehended and sent to prison, on the 
road to which he was knocked off his horse and narrowly escayed being murdered. At the time of his sequestration he was sixty years old, with a wife and numerous family, hut he had a small paternal estate at Colne, in this county, to which he withdrew, and where he died in 1657. He is said to have been Ienrned in medicine and law as well as his orn yrofession, and a man of very blameless life.

"Ingham, on the contrary, was so illiterate as to be scarcely able to write his name; and in principle so pliant that the vicarage of Ribchester, having been augmented by the usurping powers with forty pounds per anuum, their usual allowance for small benefices, he found it wortll his while to conform at the Restoration and kept possession of it."' (Walker, Sufferings of the Parochial Clergy.)

The following extract from the parish registers at Ribchester relate to Longridge Eeclesiastical history of this time:165 . $^{2}$

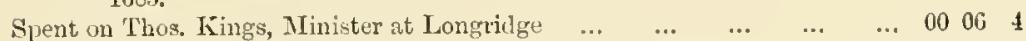

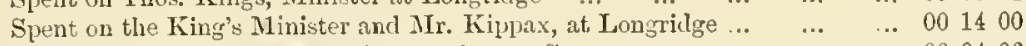

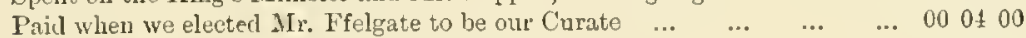
1690.

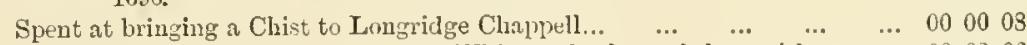
Spent at Longridge ChappeIl on Mr. White and others of the parish.. $\quad$... 000206

The difficulty, great in any case, of finding out the ecclesiastical history of Longridge in the 17 th and 18 th centuries, is considerably enhanced by the fact of its being only a chapel of ease under Ribchester. Accordingly, the registers of baptisms, marriages and burials are preserved at Ribchester, and signed generally by the vicars of that parish. However, by carefully comparing the names of the varions "officiating," i.e., temporary ministers, who performed services at Ribchester, with the names of known vicar's of Goosnargh, Chipping, Balderstone, and other places in the vicinity, I find the following persons who were in all likelihood curates of Longridge. The registers, etc., of the church do not begin till 1760, and they do not contain anything of importance except the commencement of the present mode of choosing the churchrardens. No mention is made in them of any curate of Longridge prior to the Rev. Robt. Parkinson.

\footnotetext{
${ }^{1}$ Unlike Timothy Smith, at the neighbouring chapel of Longridge.
} 
We know, however, that Longridge Church was re-built in $1716,{ }^{1}$ as in 1702 the learned Bishop Gastrell, of Chester, on his visit to the place, directed that the chappelry ought to repair the Chapel, and not the whole parish (Ribchester); but it is recommended to do it out of courtesy. He mentions that the Church at Longridge was serred once a fortnight by the Vicar (of Ribchester), who had an order from Bishop Pearson 'to receive the revenues belong to this Chapel.' "The value of the living was $\mathfrak{E} 413 \mathrm{~s} .4 \mathrm{~d}$. at this time."

In 1756 the living was augmented, as a tablet in the Church declares: "A.D. 1756, this Church of Longridge was augmented, and A.D. 1760, lands purchased with $£ 400$, whereof given by Queen Anne's Bounty $£ 200$; by executors of William Stratford, LL.D., " $£ 100$; by other benefactors $£ 100 . "$ In 1784 the Church was again re-built, and a parsonage house was built, for the first time, towards the end of the century. What the cost of this "re-building" was I do not know, but apparently it would not be much, judging from the subscribers towards re-altering " the augmented Chapel of Longridge ", in 1784-5: The Earl of Derby, £5 5s. Od.; Mr. Fox, Ribchester, £2 2s. Od. ; Rev. R. Parkinson, Rev. M. Atkinson, Cuth bert Singleton, William Bourn, James Pye, Richard Eccles, John White, John Bradley, George Charnley, T. Walmsley, D. Nuttall, John Cross, J. Billington, Nicholas Bourn, Edmund Eccles, W. Lund, N. Noreross, C. Buck, John Singleton, A. Beesley, J. Pye, W. Lancaster, Richard Dixon, Richard Radeliffe, each a guinea; and other smaller subscribers, amounting to $£ 45$.

An assessment of $2 \frac{1}{2} \mathrm{~d}$. in the pound, for the same purpose, was made in February, 1784, and amounted to $£ 511 \mathrm{~s}$. 6d., for Alston township. Some of the items in the bills are worth re-production :-

\footnotetext{
1 Baines says 1690.

2 Some account of this geuerous bene. factor of poor churches deserves to be given. A relation of the Bishop of Cliester, Dr. Stratford was born in 1759. He was the secretary of Bishops Stratford, Dawes and Gastrell. His benificence was the uore extraordinary as he was by nature frugal and
}

penurious. By means of his beuefactions apwarcls of sixty small livings were augmented. Amongst themHongridge, Whitechapel, Garstaug, aud VVoodplumpton, benefited to the extent of $\$ 100$ each. He died on September 7th, 1753, aged 75 - (F. R. Fiaines Notitia Cestriensis.) 


$$
\begin{aligned}
& \begin{array}{cccccccccc}
2 \text { prare of hinges and scrues } & \ldots & \ldots & \ldots & \ldots & \ldots & 0 & 2 & 0
\end{array} \\
& \begin{array}{lllllllllll}
7 \text { quarts of ale } & \ldots & \ldots & \ldots & \ldots & \ldots & \ldots & \ldots & 0 & 3 & 0 \\
\hline
\end{array} \\
& £ 0 \longdiv { 5 \quad 6 }
\end{aligned}
$$

"An account for liquor to the rorkmen of the Chapel " amounts to £2 8s. 9d., from May 18th to August 16th, 1784. No less than 42 quarts were drunk at the "rearing." The old font was marle by Edward Greenmood and Co., masons, Lougridge, in 1786, and cost $£ 1$ 3s. 10d. The registers date from 1760 , the oldest tombstone bearing date 1789 .

The following, taken from the minute book of the xxiv or Vestry of Ribchester, is interesting:- "Whereas, an old Bazoon mending and new one with two landles, stand in this book charg'd to the Parish. The Major part of the Vestry assembled at this meeting on Easter Tuesday, in the year 1794, Do agree and bide ${ }^{1}$ that the old Bazoon shall belong to the Parish Church of Ribchester, with one Handle, and the new Bazoon and Hautboy shall belong to the Chapel of Longridge as their each respective rites."

In 1822 the Church was, for the third time, re-built; but if its present state is any criterion of what it was in 1716 on its first rebuilding, it must have been in a truly pitiable condition; for by no possible charitable contrivance can the Parish Churel of Longridge be called anything but a "barn-like building." The cost of the restoration in 1822 can be gathered from the inscription on a second tablet in the Church:-"A.D. 1822. This Chapel was enlarged, and 309 additional sittings obtained, by a grant of $\mathfrak{L} 240$ from the Society for Promoting the Building and Enlarging of Churches and Chapels, and other benefactions, of which number 237 , in addition to 271 formerly provided, are free and unappropriated. Robert Parkinson, minister; Edmund Sagar, John Seed, Chapel Wardens."

According to this inscription, there were considerably over 600 sittings in the Chureh.

In 1834 the value of the living was $\$ 107$.

${ }^{1}$ Bid.

${ }^{2}$ Richts. 
In 1811 the present tower was added, the date on a stone commemorating the event.

From 1822 to the present time (1888) no extension (to speak of) of the accommodation provided for Church of England worshippers has taken place, although during that time the population has increased from 1,917 in 1822, to 4,000 in the present year (1888).

The Church accommodation at that time (1822) was 650 , but the pews were (and are now) so narrow that it was impossible for the worshippers to kneel during service. So we see that the Church accommodation is precisely (or nearly so) the same to-day as it was 66 years ago, although during that period the population has increased over 100 per cent.

But it has not been for want of energy and determiuation on the part of the Church-people generally that such a deplorable state of affairs has been permitted to exist.

In 1868 Robert Smith, Esq., made an offer of $£ 1,000$ to the then Vicar (Rev. IV. C. Bache,) towards the erection of a new church, to be centrally situated. The offer was declined by the Vicar, who thought it premature.

But in 1873 a vigorons and determined effort was made to completely remore such a state of things, which was declared by the Church-people to be alike discreditable to their liberality and injurious to their highest interests.

Accordingly, at a large and influential meeting held in the Boys' School on July 20th, 1873, the Vicar in the chair, it was unanimously decided, after a protracted and somewhat wam discussion, "That it is desirable that there should be two separate churches, the first one to remain in the present position, and the new one to be erected in Berry Lane or Crumpax." A committee was formed, composed of Rev. IV. C. Bache (vicar), Messrs. J. Opons'aw, Thomas Whittaker, Robert Smith, Wm. Smith, J. P. Whittle, D. Irvin, J.P., F. Deacon, R. Owtram, 'T. Pearce, and R. H. Lightfoot. Anoug these gentlemen were the leading land owners and all the large employers of labour in the district. MIr. Benjamin Walmsloy, now Alderman Walmsley, ex- 
Mayor of Preston, was appointed Hon. Secretary of the Committee, from whose minutes I am now about to briefly quote. No less a sum than $£ 2,500$ was promised at this meeting by fire gentlemen.

On August 19th, 1873, the Vicar resigned his position on the Committee, but assigned no reason for the step. Mr. J. Openshaw was elected Chairman; and on his withdrawal, some time after, Mrr. Robert Smith was appointed. On the 2nd September, 1873, a statement was left with the Bishop of Manchester (Dr. Fraser), from which I gather the following information; aud having independently sifted the various staterents, I belicve it to be absolutely correct:-

"Increase of clurch accominodation by other Sects from 1822-73:-

\begin{tabular}{|c|c|c|c|}
\hline & & & \\
\hline . & $\ldots$ & & \\
\hline $1 \quad \ldots$ & $\ldots$ & & \\
\hline c Cha, & $\ldots$ & & \\
\hline
\end{tabular}

making a total increase of 1,300 scats. The increase was mostly from Church families, and from want of Churel accommodation." An interview was held with the Vicar by a deputation from the Building Committee on September 18th, 1873, and after fully discussing the matter the deputation withlrew, having ascertained that upon "certain conditions" of the Vicar lieing carried out he would give them, as lis assistance, "his passive consent." These conditions were declined by" the Committce. In November, 1873, a further report was presented to the Ecclesiastical Commissioners, in which it is stated that the Vicar has estimated the proportion of Church-people as two-thirds of the entire population, which, in 1871 , was $3,1700^{1}$ It is also stated that it is proposed to erect a Chureh at the cost of $£ 5,000$, to seat 500 per'sons - towards which $£ 3,500$ had already been promised; and that the promoters are prepared to provide the necessary endowment. Objection, fually, is taken to the Ticar's counter proposals to restore the old Chnrch first.

The Viear replied, in March, 1875, with a counter statement, sent to Hulme's Trustees, the Patrons of the living, in which he reiterated his total objection to the proposed Cliurch on a new site.

${ }^{1}$ This estimate was much too highone half would be nearer the mark. 
On July 16tl, 1875, matters came to a crisis, when the following letter was received from the Bishop of Manchester, through his secretary :- "The Bishop has not replied to the letter, aud with Patrons and Incumbent opposed, is in a difficulty how to do so."

In consequence of this reply the Committee decided to abaudon the scheme; and, in doing so, stated "that they willing recognised that the defeat of their project was due to the action of the Vicar of Longridge, and they presumed that as a consequence of his success, thit gentleman would accept the reponsibility of himself providing further church accommodation." Su this scheme, which liad been projected and prosecuted with remarkable skill and persistence, failed, while the Vicar and his almost solitary supporters enjoyed a great triumph. But looking back on the history of this morement, we are forced to acknowledge that Mr. Bache and his friends were wholly wrong in their opposition; and present events, viz:- the building (nearly completed) of a new Church, on almost the identical spot chosen in 1873have amply justified the promoters of Church extension at that time in Longridge.

In 1882, a determined effort was made to make a commencement of a new Church at Longridge. Since the advent of the present Vicar, service has been held in the School, as well as in the old Church, and so the want of a new Church was not so much felt as in the time of Ir. Bache. After protracted discussion, and the adoption of an infinite number of schemes, it was finally decided to build a new Church close to Berry Lane, on a site given by Mr. Rolert Smith. Subscriptions came in rapidly. In July, 1886, corner stones were laid by Lady Constance Stanley, and the Bishop of Manchester (Dr. Moorhouse), amid general rejoicings. The work has been steadily progressing until the present year, and is now within a reasonable distance of completion. Mr. Christian, an eminent London ecclesiastical architect designed the plans; the style of architecture used being of a mixed kind. The Church presents a handsome appearance, and is well and centrally situated. ${ }^{1}$

${ }^{1}$ I am unable to give a full description of the buildiug owing to Mr. Christian's want of courtesy in replying to my

letter-one of the very few exceptions to the ready willinguess shewn by all whom I have asked for information. 
The contracts have been carried out by Messrs. Kay and Piuder, stone merchants; Mr. R. Robinson, joiner; and $\mathrm{Mr}$. R. Bell, painterall of whom are Longridge men, and Churchmen. The site is well chosen, and, when a steeple is added, the Church will be a prominent feature in the landscape for miles around. It is designed to seat about 700 persous, and the sittings are to be free and unappropriated for ever. No separate minister will be appointed at present. The whole of the money required, $£ 10,500$, has been already collected, with the exception of about $£ 2,000$, which sum, it is hoped, will be raised at a bazaar to be leld in 1889. Already $£ 800$ has been raised by this popular means of obtaining money. The leading subscribers to the Church, which is to be dedicated to St. Paul, are :-

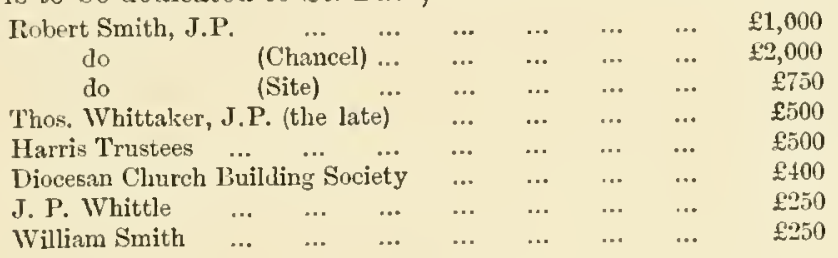

The Rev. E. Pigot, Rector of Whittington, near Carnforth, and formerly Vicar of Longridge, in a sermon preached a few years ago in Longridge Church, alluded to an interesting custom in vogue during his ministry, viz., the practice of having rushes on the floor of the Church.

From an agreement, kindly supplied to me by the Rev. F. A. CareBrownc-Cave, II.A., dated 27 March, 1837, between the Clerk, Richard Heskin, and the Churchwardens, I extract the following"He (the Clerk), shall remove the straw from the floor and lay down fresh straw when required by the Chapel Wardens."

The singing gallery was somewhat different in Mr. Mande's time (1847) to what it is now.

"Old Bob Booth," says Mr. Hoole, "played a 'bassoon,' while William Eaves played the big fiddle, and W. Rhodes manipulated the clarionet. It was quite a treat to hear old Bob Booth." 
A very faithful and at the same time a rather racy account of Longridge Church as he found it in $1872,{ }^{1}$ is given by Mr. A. Hewitson, in his work, "Our Country Churches and Chapels."

"St. Lawrence's Chureh, stands upon an eminence immediately" behind the Duke William Inn. ${ }^{2}$ To tha right of the Duke William there is a gate leading into the churchyard, which is very irregular in shape, ${ }^{2}$ and contains ntmerous gravestones, the oldest bearing the date 1791. ${ }^{3}$ From the yard there is a very fine view of the valley of the Ribble and its surroundings. In the churchyard wall, near the porch, there is a square stone, taken out of the debris of the old school, formerly on the south side of the Chureh, but which was pulled down in 1832, bearing the inscription: 'A schrol erected by private contributions for the public good, 1731.",

Entering the Church Mr. Hewitson continues his description as follows: "Nenrly all the pers on the ground floor are open, sloped at the back, narrow in the seat, and wretchedly bar to sit in." They are the strangest, the most lumbering, and uneivilized perws we have noticed. during the whole of our rambles. We prefer the old boxed-up kind to them. The roof is flat, somewhat low and supported by foul cross beams, and ornamented by two heavy-looking cilcular rentilators. The side walls are coldly prosaic, and the chancel has a ealm, whitewashed, railway-arch look, with one of the poorest and most unedifying windows in it that can be imagined. ${ }^{\circ}$ Not a poorer ehancel is there in

Since 1572 numerous changes have taken pliace in the neighbourhood of the Church. for the old Duke William Inn was pulled down a few years ago, and a fresh Inn erected oppositc the Church.

${ }^{2}$ The addition of the old Duke William site and otler land for burying purposes has altered the shape of the churchyard and improved its appearance very much for the better.

3789 is the oldest date in the churchyard.

${ }^{*}$ Mr. Hewitson has not overdrawn his picture at all, as the writer has known, to his misery, many a long Sunday. And in the galleries, the seats are Norse than downstairs, as in the front pews you hare no room for your legs.
"Up to a short time ago (3 years) there used to be about seren or eight panes of "stained class" in the chancel window. They would cover about 1 square foot altogether. Why they had been put in, aud they only, puzzled the writer many a time when attending church, and a puzzle to him they still remain. Some years aro, just after it had been decided not to rebuild the old church, the whole of the east window blew in, a curious instauce of one of the proverbial " juds. ments of beaven." The yines of coloured glass were removed at this time. The locomntive pews have been replaced by fixtures, out of which is at present occupied by MIr. Alfred Ascroft, a son of the late Town Clerk of P'restun, Mr. Robert Ascroft. 
any church than in this. It gives you the east wind when you look at it. Hanging against its wall there is a tablet to the memory of the Rev. Robert Parkinson, who was minister at the Church for 48 years, and another equally liumble to the memory of the Rev. George Parkin, who officiated here for a short time, died suddenly on Sunday, the 27th March, 1831, and was interred on the northern side of the pulpit, near the spot where he was taken ill."

"An ancient and most orthodox ' lion and unicorn' painting is fixed in front of the ehancel arch." On each side of the arch-at the base of it-there is a strong, neatly-lined pew. Both run on castors, in order that they may be removed on speeial occasions." "Whose seats are these?' said we to a gentleman who walked round the Church with us after the service, and he replied, 'Mr.' Ascroft's, Town Clerk of Preston.' 'Does he attend often and pray hard?' said we, and he answered cautiously, 'He comes when he likes.' A lawyer would have said, 'That is not an answer to the question, sir,' but we kept calm, said so beit, and admired the locomotive seats before us."

Referring to the singing, Mr. Hewitson says it "is done in a very high pressure, go-ahead, scarlet-fever style, which does not always harmonize with ono's notions of saered pralmody."

A font, which formerly stood in Preston Parish Chureh, was given by Mrs. Wilson, of Broom Hill, Longridge, and was removed from her garden to Longridge Church in July, 1877.

The advorson of Longridge Chapel was ariginally in the possession of Sir Henry Hoghton, Bart., from whom it was bought on 26 December, 1829, by Hulme's Trustees. It is now a vicarage returned in 1888 at $£ 450^{2}$ net, with house, made up as follows:-Tithe rent charge, $£ 260$; ground rent, $£ 100$; glebe lands, $£ 90$. Church accommodation, $680 .^{3}$

\footnotetext{
"The "lion and unicorn" painting was renoved from in front of the chancel arch in 1878, as the new Vicar, Mr. Care, was afraid of it coming down on his head. It is now ou the wall over the main entrance to the church.
}

'The value of the living is now considerably less than $£ 450$.

"The return marle to the "Diocesan Directory" of 1S58, is euriously inaccurate:-" 340 sittings, 40 of which are free." 
I am indebted to Mr. J. H. Longworth, of the firm of Longworth and Gardner, Preston (the Vicar's agents), for the folloming information:-

"Previous to 1735, Longridge Chapel'y does not seem to hare had any endowment whatever. ${ }^{1}$ In that year a farm in Goosnargh was purchased with the proceeds of private benefactions, assisted by a small grant (£200) from Queen Anne's Bounty. In 1743-5 another fund seems to have been raised, and with that and a further grant of $£ 200$ from Queen Anne's Bounty, a farm, also in Goosnargh, called "Yates' Tenement," was purchased. In the year 1760, a cottage and land, other part of 'Yates' Tenement,' in Goosnargh, and 2 fields in Preston, were purchased.

"In the year 1826, with all usual formalities, the Rev. Robert Parkinson, the then 'incumbent curate' of Longridge, exchanged the 2 fields in Preston for the 'Old $\nabla$ icarage' house in the village, and 17a. 3r. $9 \frac{3}{4} \mathrm{p}$. of land in Alston and Dilworth, of which the present glebe land forms part. In the conveyance of the latter, it is stated as the reason for the exchange, to be 'situated conveniently for actual residence and occupation by the Incumbent of the Curacy,' and that the same were also of greater value than the land in Preston, and were conveniently situated.

"The Old Vicarage house was sold in 1846 , to the late George Whittle, Esq., and with the proceeds and private subscriptions the land for the present Vicarage in Lower Lane, Alston, was purchased, and a new Vicarage house erected.

"In the year 1862, the Trustees of the Estates devised by Wm. Hulme, Esq., who are the Patrons of the living seem to have purchased the Vicarial Tithe Rent Charges, commuted at $£ 34$ per annum, arising out of the Townships of Alston and Dilworth, for $\{750$, for the purpose of 'augmenting the Endowment of the Church or Chapel of St. Lawrence, Longridge.'

"The 2 farms in Goosnargh wore sold in 1855 and 1859, the procceds being invested in Consols. In the year 1864, certain ground rents on properties in Preston were purchased from the late Edward Pedder's 'Trustees, and paicl for by proceeds of Consols sold out for that purpose.

${ }^{1}$ But see page $5 \%$. 
"The Great or Rectorial Tithes of Alston and Dilworth, converted into a perpetual Reut Charge of $£ 232$ per annum, were purchased in the year 1869 for $£ 3,300$, and paid for, partly by a special legacy, a gift for that purpose, ${ }^{1}$ and partly by private subscriptions raised by Rev. W. C. Bache, the then Vicar. The Tithe Rent Charges are subject to all parochial rates and taxes, and in this respect only differ from ordinary ground rents.

"By statute of 31 and 32 Vict., cap. 117, it is provided, that certain Incumbents should be deemed and styled 'Tiears, and their benefices Vicarages.' Under this Act the Incumbent Curate of Longridge became entitled to the title of Vicar."

There are two handsome schools side by side in Longridge in connection with the Church of England. The Girls' School was erected in $1865,{ }^{2}$ and enlarged in 1878 . It is capable of holding 300 children, and in 1887 had a daily average attendance of 140 .

The Boys' Sehool was built in 1885, at the sole cost and expense of Robert Smith, Esq. J.P., as a liandsome brass on the school wall testifies. It will hold 350 boys, and had a daily average attendance of 163 in 1887.

The old school, now used as a wheelwright's shop, was erected iu 1832. One anterior to it wis erected in 1731. It was a low bnilding, badly lighted, and worse ventilated, and was inconveniently situated, being opposite the P'arish Church.

Vicars of Longridge.

A.D.

1554 (?)-Sir Robert Cottom

164 (?)-Rev. Mr. Harley.

1650.-Vacant.

165 (?)-Timothy Smith.

1662.-Timothy Smith, ejected.

'This legacy was, I understand, the gift of Aliss Buck, sister' to $\mathrm{Mr}$. Wn. Buck, Alston Lodge, Longridge.

In referring to the opening of the new School, at a Mleeting held on Aug. 10tl, 1867 , the Rev, IV. C. Bache made an interesting statement. Among other things he mentioned his gratification at fuding such spontaneous aid and kindly help had been given, particularly by Mr. George Whittle and Mr. Jonathan Openshaw, and to the working people of the place who had come forward so manfully and nobly. 
June 9, 1701.-Thomas Felgate.

Ang. 31, 1730.-Richard Dixon.

Sep. 23, 17t3.-Joln Sharpe.

April 10, 1780.-Robert Parkinson.

Mar. 28, 1829.-George Parkin.

July 20, 1831.-Frederick Mande, MI.A.

Oct. 10, 1843.--Edward Pigot, B.A.

Aug. 16, 1857.-William Charles Bache, M.A.

April 3, 187\%.-Fitzherbert Astley Cave-Browne-Cave, M.A. SIR ROBERT CòTTOX-A.D. 1554 (?).

From the deposition of William Hothersall, (made before the Bishop of Chester in 1556), the probable Lord of the Nanor, "Sir Robert Cotome, priest of Longriclge, in Ribchester," is said to have "long placyd the blissed housel, beyng the ghostlye bodye of our Lord Christ for the cleanseyng, on the holly altar in Langrig Chapel, and had formerly mynistered to the Pryest. He was able to read the gospell and mynister divine offyces, although a Decon only, nor could he be Prested untyl Alhallowtide. He was grave and chaste, could play on the musiques, and was no typler nor dyce man."- "Lanc. MSS., vol. xxii."

From which interesting account wo gather that, Sir Robert Cottom had been Curate to the former priest, and that he had been temporarily taking charge of the Church. His character was very good, and contrasts favourably with that of the late Curate of Preston Parish Church, Sir Wm. Wall, who is described by his Vicar in 1574, as so accustomed to "geve ye Sacrament into their monthes that they will not take it to ye handes; hee wynketh att them that have their childre chrystend at their hands of onld prestes in houses; hee canseth bells to be ronge for sonlls when I am preaching the gospell, and alsoe cometh boldlye to mee and byd mee cone downe; he never wold saye the evening prayer on Saterdines, but onlye Rynge to mocke God and the people; he marrieth coples together, with many other abuses long to reherse."-"Lane. MSSS., rol. xxii."

I have not been able to obtain any additional information about Sir Robert Cottom. 


$$
\text { REV. MR. ILARLEY-164 (?)-1647 (?). }
$$

There seems to be little doubt that $\mathbf{M r}_{\mathrm{r}}$. Harley was Curate of Longridge at this time, as the following extract from the Crommellian Survey in 1650 shows:-

There is belonging to the parish [Rilochester] ffive Townshippes, viz.Ribchester, 1)ilworth, Howston [Alston], Tenesee [Hothersall], and Dutton; the tythe of the sainl parish . . . . . The Kishopp always allowed twenty markes jer annum towards a minister out of the rent; they are at present without any Minister, only hire so often is they can, And pay the minister soe farre as the twenty markes will goe, and make up the rent of theire owne parses. There was one Mr. Harley Curate there, but was put ont by the Committee of Divines in Lan. cashire for his insufticiency and being scandalous in his life and conversation.

Christopher Hindle was the Viear of Ribchester from 1617 to 1651 , when he was deposed by "one Ingham;" so that Mr. Harley would, without doubt, bo the Curate of Longridge. I can find no further reference to Mr. Harley, a fact, nuder the cireumstances, perhaps not to lie regretted.

$$
\text { TLIOTIY SALTII }-165-1662 \text {. }
$$

Timothy Snith was appointer on the petition of the inhabitants, who in 1650 were without any Priest, as they well might be, seeing there was no endowment. He was a rery conscientious man, and in 1662 was ejecter, because lie would not give his full adhesion to the Prayer Book, in conformity with the Act of Uniformity. ${ }^{1}$ But euriously

${ }^{1}$ The Conmission appointed in 1650 to ohtain the consent of the Vicars of the Churches anil Clrapels in Lancashire, to the "Harmonious Consent" reported that there were at that time 63 Parish r'burches, and 118 Chapels, of which no less than 35 were without Ministers, chiefly for want of maintenance. The following talle sloows who signed the "Consent" in this neighhourhood:-

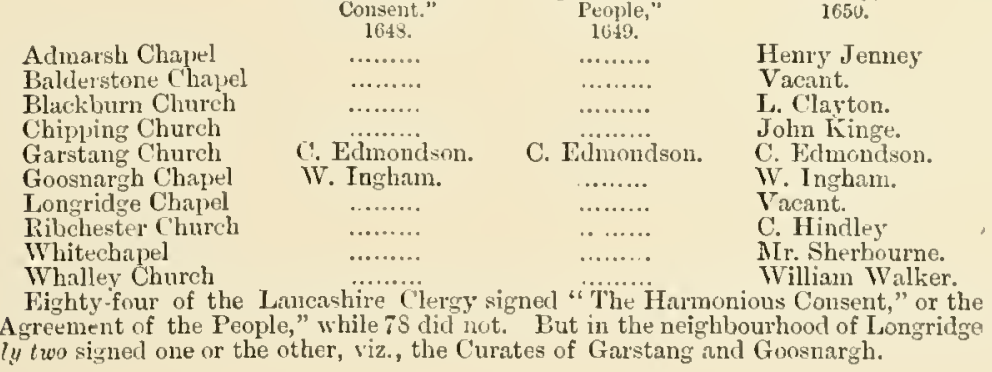

$$
\begin{aligned}
& \text { signature to Simature to the } \\
& \begin{array}{l}
\text { "Armonious "Agreement of the Survey, } \\
\text { People," }
\end{array}
\end{aligned}
$$$$
\text { Vac...... Vant. }
$$$$
\text { c. Clayton. }
$$$$
\text { John Kinge. }
$$$$
\text { IV. Ingham. }
$$$$
\text { Vacant. }
$$$$
\text { C. Hindley }
$$$$
\text { Ar. Sherbourne. }
$$$$
\text { William TValker. }
$$

"A only two signed one or the other, viz., the Curates of Garstang and Gonsnargh. 
enough he often, even after this, preached in the Church, as Dr. E. Calamy, in his "Nuncouformist Memorial" quaintly remarks, " $\mathrm{He}_{\mathrm{e}}$ did not conform, he ofteu preached in the Chapel after his ejectment, for, this being an obscure place, with a small salary, there was no great striving after it."

There exists in Longridge to-day what will be iu all probability a lasting Memorial of this conscientious man, viz., the Independent Chapel. For, in the preliminary circular issued by the promoters of the Chapel appears the followiug paragraph:- "At Longrilge a devoted Minister of Christ, the Rev. Timothy Sm:th, was ejected from the Parish Church in 1662, because he could not, with a safe conscience, subscribe to the Act of Uniformity. What more suitable memorial of that event than to erect a substantial Place of Worship, in which the glorious truths and principles held by the 'Noble Confessors' of 1662 , may be proclaimed aud perpetuated from age to age."

Little did the Rev. Timothy Smith imagine that such a noble monument would perpetuate his adherence to the dictates of his conscience. But it is only one more instance of the truth, that "the good men do lives after them."

He died very poor, in 1679, aged 60.

It may be interesting to give as full a list as possible here of the local clergymen who refused, and of those who assented, to conform to the Act of Uniformity of 1662. The Nonconformers were :-

Timothy Smith, Longridge.

${ }^{1}$ Isaac Ambrose, Garstang.

Mr. Sandford, Great Harwood.

William Moore, Whalley.

The Conforming clergy were :-

John King, Chipping.

IVilliam Ingham, Goosnargh.

Mr. Ingham, Ribchester.

Leonard Clayton, Blackburn.

Is very interesting account of the life of Mr. Ambrose is given by Colonel Fishwick in the "History of Kirkham," vol. ii.
${ }^{2}$ Fishwick doubts whether Mr. Ingham was at Goosnargh in 1662 ; but he was not one of the "ejected." 
It may not be considered out of place to give the following quotation from Mr. J. R. Green, the historian of England, as his remarks are eminently just :-

A more deadly blow was dealt at the Puritans in the renewal of the Act of Uni. formity. Not only was the use of the Prayer Book, anel the Frayer Book only, enforced in all public worship, but an unfeigned co: sent and assent was demanded from every minister of the Chureh to all which was contained in it. It was in vain that Ashley opposcd the hill fiercely in the Lords, and that even Clarendon, who felt that the King's word was at stake, pressed for the insertion of clauses enabling the Crown to grant dispensations from its provisinns. On St. Bartholomew's Day, nearly two thousand rectors and vicars, or about a fifth of the English clergy, were driven from their parishes as Noncunformists. No such sweeping change in the religions aspect of the Church had ever been scen before. . . . . The rectors and ricars who were iriven ont were the most learned and active of their order. The bulk of the great livings throughout the country were in their hands. They occupied the higher posts at the two universities. No English divine, save Jercmy Taylor, rivalled Howe as a preacher; no parsou was so renowned a controversialist, or so indefatigable a parish priest, as Baxter. . . . The expulsion of these men was far more to the Church of Eugland than the loss of their individual services. It was the definite expulsion of a great party which, from the time of the Reformation, had played the most active and popular part in the life of the Church. . . . The Church of England stood from that moment isolated and alone among all the churches of the Christian world. . . . . From that time to this (1S74) the Episcopal $\mathrm{Cl}$ urch has been unable to meet the varying spiritual needs of its adherents by any modification of its government or its worship.

Mr. Green then goes on to point out how this ejection of conscientious clergymen proved of the highest advantage to the cause of religious liberty - the right of every man to worship God according to the bidding of his own conscience.

Into the birth of Dissent and the sufferings of the Nonconferming ministers, we have no space to enter. All know how John Bunyan, who was a Baptist, suffered; and as he suffered, so, in a greater or less degree, did the bulk of the Nonconformists suffer in the latter half of the seventeenth century.

REF. THOMAS FELGATE- $1701-30$.

The Rev. Thomas Felgate was nominated to the curacy of Longridge by the Rev. George Ogden, Ticar of Ribchester. No other information can be obtained from the registers at Chester, or other sources.".

${ }^{1}$ See Appendix B. 


$$
\text { REV. RICHARD DIXON-1730-43. }
$$

The Rev. Richard Dixon was appointer to the curncy of Longridge Church on the nomination of Sir Henry Hoghton, Bart., the patron of the living. He died at Longridge in 1743 .

$$
\text { REV. JOHN SLLARPE-1743-80. }
$$

Sir Henry Hoghton, Bart., also nominated the Rev. Joln Sharpo to the curacy of the Church at Longridge, on the death of Mr. Dixon, and it appears he died in March, 1780, according to a document in my possession, which states that the vicarage (or curacy, as it then was) of Longridge was vacant on March 15th, 1780, as is declared by a "letter of sequestration" bearing this date, addressed to the Rev. Robert Parkinson (soon afterwards appointed vicar), and George Ratcliffe, chapel warden. Mention is made of the late vicar, the Rev. John Sharpe.

So scanty are the records of ecclesiastical history of Longridge down to 1780 , that we can find absolutely no information, beyond that already given, about the Vicars of Longridge, notwithstanding that most careful and diligent search has been made among the church papers of the various parishes in the district. Nor can we find that any of these gentlemen held any other appointments prior to their being at Lougridge (except Rev.T. Smith, who was curate of Bradshaw). REV. ROBERT PARKINSON-1780-1829.

The Rev. Robert Parkinson, whose nephow, Canon Parkinson, of Manchester, was the distinguished author of "The Old Church Clock," and other works, was perpetual curate of the Chapelry of Longridge for forty-eight years. He was appointed in 1780, and died in 1828, aged 72. "He was," says Canon Parlinson in his "Old Church Clock," "the Robert Walker of a somewhat higher tone and sphere. His income from his living, during the time of his incumbency, rose from about $£ 10$ a year to $£ 140$, where it stopped. The pepulation in the meantime-of the worst kind as far as ninisterial labour is concerned, being universally poor, and consisting one-Lalf of Roman Catholics, and almost all poor hand-loom weavers-advanced from about 400 to 2,000 . During his incumbency he enlarged his small Chapel, without any expense to the place, so as to hold 700 worshippers, and left behind him what he did not find-a parsonage 
house. Nor was there erected (and this is a singular exception in that district,) during his incumbency a single Dissenting place of worship of any kind in his chapelry." An event occurred to Mr. Parkinson, somewhat similar to the one recorded of Robert Walker, "which I," says Canon Parkinson, "will not soon forget. At the first visitation dinner which he attended, the whole party rose from the table when my venerable relative took his early departure, as a mark of respect for his high character."

The Rev. R. Parkinson was preceptor to Canon Parkinson, and, according to a local authority, he was " a very respectable old gentleman, who preached to the peoplo on Sundays, and reconciled their differences during week days."

A marble tablet in the chancel of the Church fittingly records the virtues of Canon Parkinson's uncle:-

$$
\begin{aligned}
& \text { In Memory of } \\
& \text { The Late Rev. ROBERT PARKINSON, } \\
& \text { Who, for the period of } 45 \text { years, } \\
& \text { Discharged the Ministerial duties of this Chapel. } \\
& \text { He departed this life Nov. 21st, 1828, aged } 72 \text {. } \\
& \text { IHis couduct both as a spiritual pastor } \\
& \text { And friendly counsellor } \\
& \text { Was such as to lender hin highly beloved } \\
& \text { By a large circle of friends during life, } \\
& \text { And greatly lamented in death. } \\
& \text { This testinony of grateful affection } \\
& \text { Is ereeted in dutiful remembrance } \\
& \text { By his only surviving daughter. } \\
& \text { RET. GEORGE PARKIs-1829-31. }
\end{aligned}
$$

The liev. Robert Parkinson was succeeded as Vicar of Longridge, by the Rev. George Parkin, but this latter gentleman only held the incumbency for the short space of two years, dying suddenly on the 27th March, 1831. He was taken ill one Sunday, having just read prayers, and preparing to preach, when he was seized with a fit, and lingered till evening, when he diod, and lies buried within the church on the northern sirle of the pulpit, near the spot whero he was taken ill.

${ }^{1}$ Truly, as Canon Parkiuson infers, this was a remarkable fact ; but during the next forty years we see what took place in this respect. 
A marble slab within the chancel is erected to his memory :

Sacred to the memory

of the Rev. GEORGE PARKIN,

who departed this life

the 27 th March, A.D., 1831, aged 67 years.

Blessed are the dead which die in the Lord,

Even so saith the Spirit; for they rest from

Their labour, and their works do follow them.

For if we believe that Jesus died and rose again

Even so them also which sleep in Jesus

IVill God bring with Him.

REV. FREDERICK MAUDE, M.A.-1831-43.

The Rov. Frederick Maude, M.A., followed Mr. Parkiu, and held the living for nearly 12 years. Mrr. Mande was a delicate man, and so did not mix as much as he could have liked with the people. He was considered a very good prencher, and although he was a very sedate man and wanted lnowing, he was popular among his parishioners. He was very intimate with the Birley family, and the Rev. Wobber Birley often nsed to prench for him, when Mr. Maude was away from home. Just before Mr. Maude diod he engaged the Rev. Rd. White as his curate for twelvemonths, but the death of Mr. Maude at Kensington, on July 2nd, 1843, terminated Mr. White's engagement.

The Communion plate now in use at the Church was prosented by Mr. Maude.

A marble slab under the south gallery, in what is profanely called "Bull's Head Row,"1 is erected to his monory, and bears the following inscription :-

$$
\begin{gathered}
\text { A tribute of affection } \\
\text { to the memory of } \\
\text { The Rev. FREUERICK MAUDE, M.A., } \\
\text { of Brazenose ('oliege, Oxford, } \\
\text { And neally twelve years } \\
\text { Incumbent of this Chapelry, } \\
\text { He died at } \\
\text { Earl's Court, Kensington, } \\
\text { July 'nd, 1843, aged } 57 \text { years, } \\
\text { And is interred in } \\
\text { The West of London Cemetery. }
\end{gathered}
$$

'In this row, or aisle, sit most of the youths and bachelors of the congregation. Why such a practice, so provocative of disorder, should be tolerated is one of those things we do not comprehend. 
REY. EDWARD PIGOT, B.A.-1843-47.

The vacancy cansed by the death of the Rev. Froderick Maude was filled by the appointment of the Rev. Edward Pigot, B.A. Mr. Pigot was a young cuan almost fresh from the University when he came to Longridge, having been Curate of Deane for two years. He was a fine man, a good preacher, and very popular. It was during Mr. Pigot's time that the practice of putting straw on the floor of the Church was put a stop to. Other decided improvements were also due to him, and to the late Mr. R. Dixon, from whom he received warm support.

Mr. Pigot is now the Rector of Whittington, near Carnforth. He has also hell the following appointments: Curate of Wigan; and Vicarage of St. Thomas's, Ashton-in-Mackerfield.

$$
\text { REV. WILLIAY CHARLES BACHE, M.A.-1847-77. }
$$

Mr. Pigot was succeeded by the Rev. William Charles Bache, M.A., being the last appointment to Longridge sanetioned by the Bislop of Chester, as the new diocese of Manchester was created in 1817. Mr. Bache remained Vicar for the long period of 30 years, having resigned the Vicarage of Longridge in 1877 on lis appointment to the Rectory of Alresford, near Colchester.

A rather free but in many points an eminently just criticism by "Atticus" of Mr. Bache's manner and style of prenching relieves me from a somewhat awkward dilemma, as it would not have been easy for me to havesaid (without pain) just what I thought on the matter, or to escape the charge on the other hand of truckling. "The minister of the Church," says "Atticus," "is the Rev. W. C. Bache. Emerson, quoting somebody else, says that a man's religion may be found out by the nature of his biliary duct. We are inclined to that opinion. Father Bache is a corrugated, solemnly-shrivelled, good-hearted, pious, faded-marigold-looking man, with a very white necktic-luas a defective biliary duct-looks too darkly yellow; is cautious; would feel if the water were cold before drowning himself; and yet he means well. A phrenologist and physiognomist would sny that, he would have made a better Methodist circnit superintendent than Cluurch of England Ineumbent-a better advocate of Zimmorman's 
Solitude than of active clerical business. Tet he is a man of good parts. He has rather delicate health, but is a very fair visitor, ${ }^{1}$ and likes to know the circumstances of his parishioners in order to help the deserving without respect to creeds; believes in good old English Church service-as it should be observed, free from the errors of Ritualism. He is placid with those who differ from him, but occasionally utters a cry against the errors of Rome, etc. Would be better aware of the struggles of men with large families if he had had some experience, but never having embarked on the sea of matrimony has to believe what he hears, ${ }^{2}$ is quiet, and if determined to be very cool should have a curate. $\mathrm{Hl} e$ is a methodical orthodox, sanctified preacher, and fancies that the Incumbent of Longridge Church is now, and for some time has been, the equal to a 'Delphic pythoness!'"

Shortly before Mr. Bache left Longridge, on his appointment to the Rectory of Alresford he was presented with a handsome silver tea service, and other objects for his sister, as a "substantial token of affection and respect" by his parishioners. At a meeting, held on December 4th, the Rev. B. Haslewood, Vicar of Ribchester, said that he thought that in the quiet and faithful discharge of his ministerial duties in the sick room and by the bedside of many a suffering member of his flock, they had a very happy illustration of Chaucer's "Poor Parson of a Town."

Mr. Bache was a model visitor of the sick, and looked well after the Sunday Schools. His action on the Church building question is narrated in the preceding portion of this chapter.

\footnotetext{
${ }^{1}$ As a visitor, I am told by many veople, Mr. Bache was unsurpassed. I have met him almost every day when going home to diuner from the mill, and remember noticing how frequently he was visiting the sick and poor. This trait of his character should make (and I believe it has clone), his many illjudged actions forgotten.

2"Atticus" evidently did not know Miss Bache, the Vicar's sister. She ruled the parish in reality, and in many
}

things ruled it well. She was active, sharp, and above all things deternined. She used to play the piano in the Church for many years; and looked well after the Sunday schools. But Miss Bache was narrow-minded and loved her brother with all his faults-which were to her virtues - with the intense devotion of a woman, and we question whether her influence was altogether for good in this parish. 



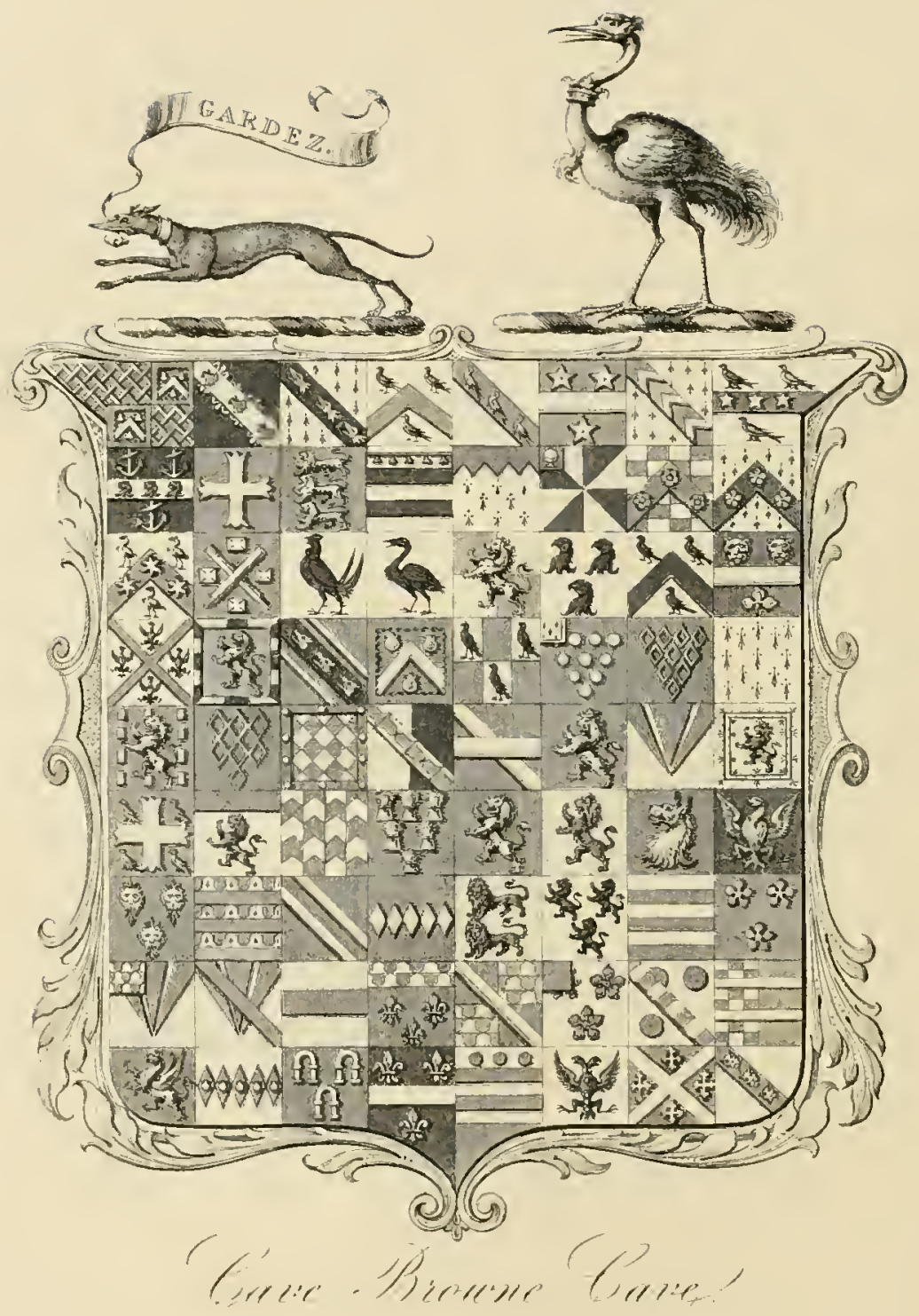


REV. FITZIERBERT ASTLEY CAYE-BROWNE-CAVE, M..1.-1877.

The present Vicar, who received, in March, 1877, a friendly call from his parishioners, and who came from Padiliam with a great reputation, is a very different man to his predecessor. The Rev. Fitzherbert Astley Cave-Browne-Cave, M.A., is as large and as fine a specimen of an English gentleman it is possible for the soil to grow. Handsome, polished, genial, and couteous, his very appearance gratified the people of Longridge. Such a contrast he was to the late Vicar, whom "Atticus" painterl for us a little while ago. So Mr. Cave came to Longridge amid the approving shouts of the Church-people; and he began his work well.

Frank and outspoken, he told the people what his views were about parish work, and at once proceeded to throw himself with characteristic energy into the task of stir ring up the somewhat stagnant waters of Longridge Church and social life. He established a Parochial Council, which soon proved a failure ; left off the absurd habit of changing his surplice for the black gown before entering the pulpit, thereby proroking only " a storm in a teapot;" instituted harvest thanksgiving services and weekly commnnions; organized a bazaar for meetingthe cost of enlarging the Girls' School, which was accomplished in 1879, and in various other ways brushed away the cobwebs which had been fast accumnlating under the rule of his somewhat jejune predecessor. If we might (with all dne respect), venture to express an upprojudiced opinion, wo should say that Mr. Cave would have made an excellent captain of Life Guards. He would have had his troop in first-rate order, a matter less difficult for one of his qualities than the disciplining of a country parish. His genial and open-hearted manner wonld have made him better suited for such persons as wonld then have been his associates than for a rustic congregation. But Mrr. Cave's influence upon social affairs in Longridge has been more marked, and, we venture to say, will show much more permanency in the end than his influence in religious matters. He instituted a Floral Society, which has just held its eleventh annual show; established a Church of England MIutual Improvement Association, which in a year became a non-sectarian debating society, and which did much good until its temporary defunc- 
tion in 1886. He took a great interest in Temperance work, and tried to make the meetings bright and pleasant. In fret, almost everything had his care and attention. In 1878, during the great strikes, he tried hard to bring about all agreement between the Longridge masters and their employés. But his great difficulty has been in promoting union amongst the people. It is well known that people in small country towns like Longridge pride themselves upon their discreetness as to whem they associate with. The result is the formation of social cliques. The consequences of such behaviour have been inimitably hit off by George Eliot in several of her movels, but this sort of thing still exists in Longridge. Tories won't visit Liberals, and vicc versa. Church-peeple do not like to associate with chapel-geers, and the latter like not the society of those who go nowhere. One family wen't visit another because of some trivial misunderstanding, and so on through the whole of the circle. The consequences are grave and serious. Disunion is promoted. Work which can only be well done by a united town is hampered and delayod. Uncharitableness prevails as well as other evils not necessary to particularize. If any one could put an end to this state of things, I should say Mr. Cave is the man. Hospitable to a fault, and a thorough gentleman, people find it hard to quarrel with him-but he has failed, so I think, to do much good in this respect. He may have softened and toned dowu the amenities of social life-that is all.

As a preacher, Mr. Cave is hard to criticize. He so seldem does himself justice. So busy is he during the week, he has no time to read or prepare his sermons as a rule, and so either repeats a string of wellworn platitudes, or loses himself in the maze of an involved argumentative disceurse. I have heard bim preach fine sermens, and, with his splendid voice and commanding appearance, it is a pity he should give himself se hittle chance in the pulpit.

Mr. Cave was formerly Curate at Cockerham, Vicar of Horton, Vicar of Ellel, aud then Vicar of Padiham. He is 42 years old, and has been married twice. His first wife was Miss Beckwith, who died soen after marriage. His present wife was a Miss Clarke, a native of Dublin. Ite has had the assistance of a curate since 1880. The fol- 



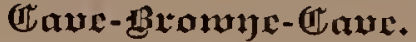

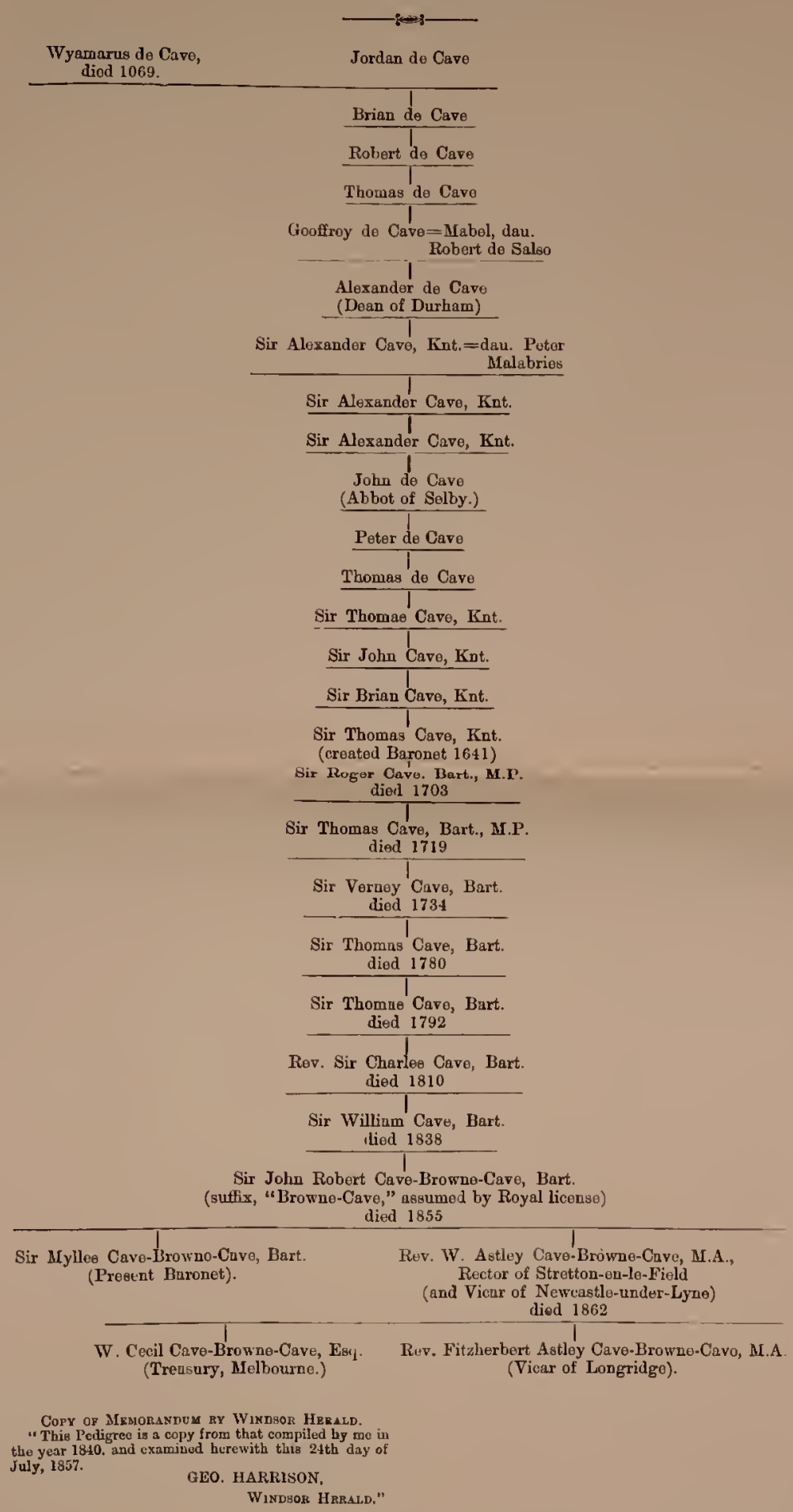


lowing gentlemen have held that post:--The Revs. J. Osborne, C. H. Gough, and H. T. Greaves, M.A., the latter of whom is curate now. The new Church scheme has had his hearty support from the first. We may add that a nseful blue book has been published by $\mathbf{M r}$. Cave every year since he came to Lougridge.

It may not be generally known that the present Vicar of Longridge comes of an ancient and c lebrate" family, the founder of which "came in" with William the Conqueror. A very witty epitaph "on one Cave" deserves reproduction :-

In the churchyard of Barrow-upon-Soar, in Leicestershire, there's a punning epitaph on one Care :-

'Here, in this grave, there lies a Cave ;

We call a cave a grave ;

If cave be grave, and grase be eave, Then, reader, judge, I crave,

Whether loth Cave lie here in grave, Or grave lie here in Cave;

If grave in Cave here buried lie, Then grave where is thy victory?

Go, reader, and report, here lies a Care,

Who conquers death, and buries his own grave.

Otier Religious bodies. Chambers" "Book of Days." THE ROMLAV CATHOLICS.

Next to tho Church of England, the Catholics are the strongest body in Longridge, but it was not until 1869 that a Church of this Denominatiou was built in the village of Longridge. Prior to this they used to worship at Alston Lane Chapel, about which I shall have something to say later on.

The Rev. Henry Brown, then of Ribchester, was the initiator of the movement for erecting a Catholic Chapel at Longridge. Пe was followed by the Rev. S. Clarkson, by the Rev. T. Davis, who saw the work completed, and was followed in 1871 by the present Priest, the Rev. Charles Boardman, D.D.

Mr. Hewitson describes the chapel (now used as a school) as graceful and solid. In the vestry, which is behind the sanctuary, there is the only curiosity about the place. It is a small brass cross, evidently made to let into a rod or staff for processional purposes, and is said 
" to have been used in the old Catholic Chapel, at Longridge, which stood upon the site of the present Episcopalian Church prior to the Reformation."

The following interesting account of this cross, from the pen of the Rev. Charles Boardman, D.D., appeared in the "Salford Almanack," 1880 :-

"The old brass processional cross now belonging to the Longridge Mission was found about fifty years ago by a boy named Seth Eccles. About 400 yards from the site of the present Protestant Church au old house was being pulled down, and this boy, with some others, was playiug about the half-demolished building. On a ledge in the chimney flue he found the cross, together with some other religious objects-he believes a chalice was among them. These other objects have become dispersed and lost sight of. There can be little doubt that this cross was the processional cross of Longridge Church before the Reformatiou, and that it and the other religious objects were hidden by some good Catholic to save them from desecratiou. The above particulars were gathered by me from the mouth of the person named, Seth Eccles, now an old man."

Dr. Boardman informs me that this cross was handed over to the Longridge Catholic Mission, 19 years ago, on its establishment in 1869. It is now, as has been remarked, in the vestry of the Church, and is certainly a very interesting relic. It is highly valued by the Rector, by whose kind permission I have been enabled to give a photograph of it.

In 1886, a very handsome now stone Church was opened by the Bishop of Salford, having been erected close to the old Church, at a cost of $£ 3,000$, chiefly by voluntary subscriptions amongst the people, and other donations obtained by Dr. Boardman's exertions. The Church is very handsomely furnished inside, although not quite fiuished. The seats are comfortable and roomy, the aisles of sufficient width, while the roof is very lofty, and the windows admit plenty of light. The Church will accommodate 500 people, the average attendance being close upon 400 at each of the three services-an attendance, we may paren thetically remark, which excoeds that at either the Episcopal or Indopendout Churches at Longridge. There is a beautifully-stained 


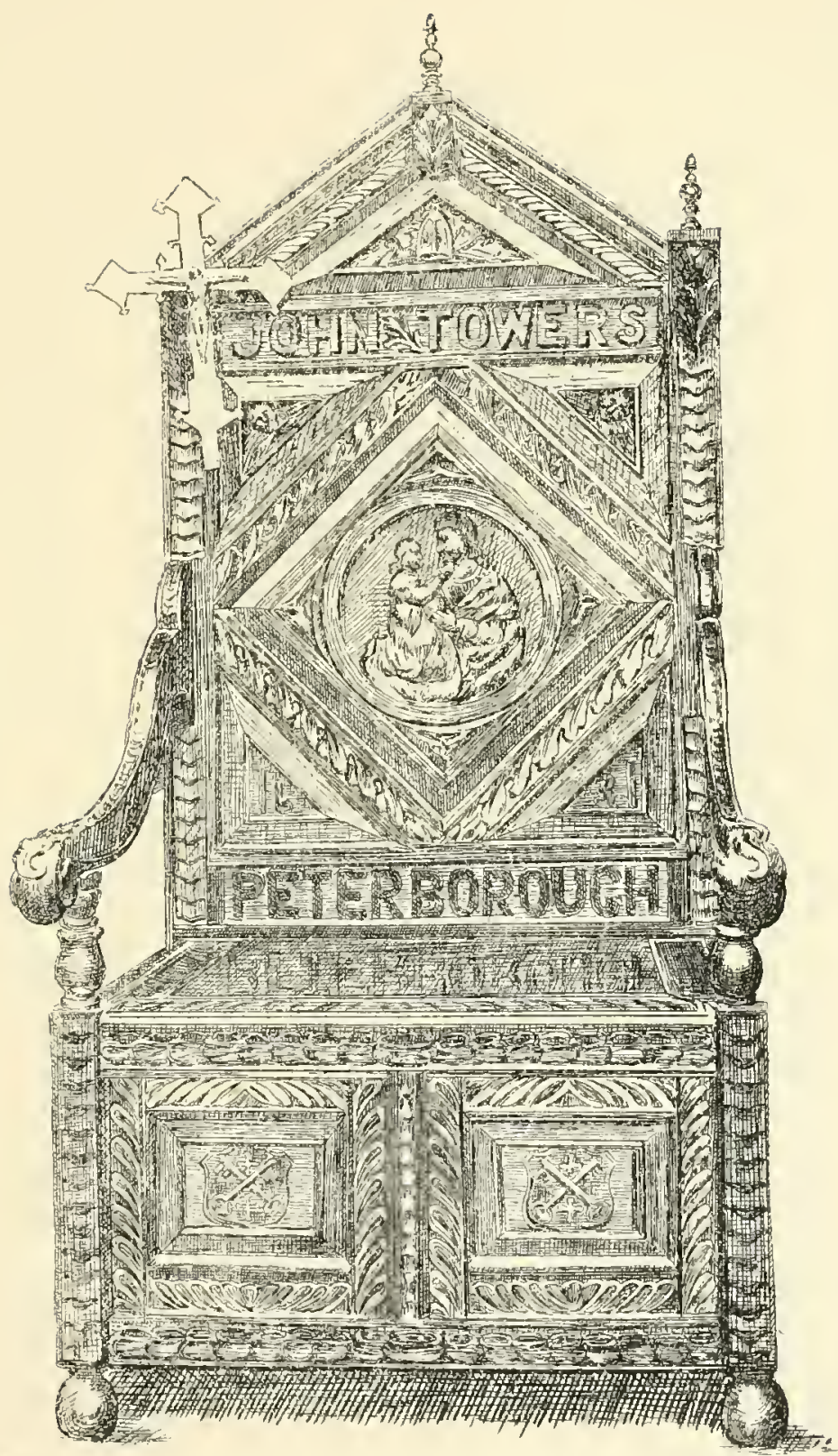

REOCESSINAL CROSE AND BISHOP'S CHAIR,

S1. Wilfrit's Chureh, Longridge. 



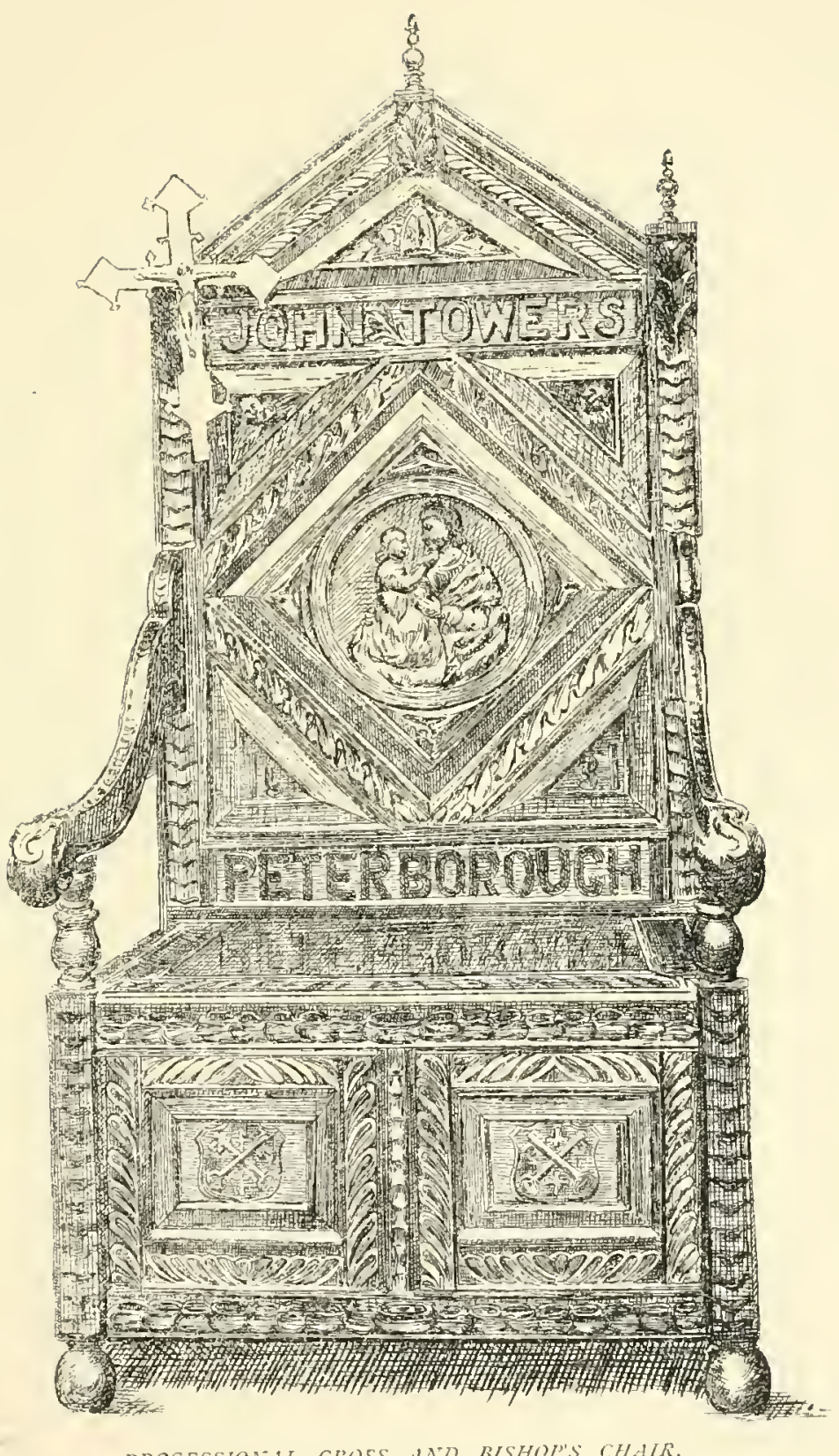

PROCESSIOUL CROSS AND BISHOD'S CHAIR,

St. Wilfrids (1/arch, longridge. 

window in the north wall, by Warrington, of London. On the walls are some good paintings of sacred subjects, two of which deserve mention. One, "The Holy Frmily," is supposed to be by Tintoretto, while the second one is by Fra Angelico. The altars are very elaborately decorated; and the pulpit, a handsome oak one, has carved on four panels the heads of the English Catholic Martyrs-Barlow, Fisher, More, and Pole. The pulpit and carving liave been worked by a former member of the congregation. Close to the altar stands an old carved oak chair in an excellent state of preservation, elaborately carved with angels' heads and various devices. It bears the following legend:--"John Towers, 1631. Peterborough." At each corner are carved the mitre and bishop's crook, while below are a pair of "cross keys." John Towers was Bishop of Peterborough ; and doubtless this chair was made in honour of his elevation to the bishopric. Dr. Boardman obtained it from a shop in Liverpool some years ago. I have also been enabled to furnish my realers with a photograph of this chair, by the courtesy of the reverend gentleman to whom it belongs.

The singing is of a high character, while the congregation, needless to say, are very attentive and devotional.

The old Church is used as a school, and has an average attendance of 165. Attached to the Church, there is a Cemetery.

The Rev. Charles Boardman, D.D., is the Rector of St. Wilfrid's Roman Catholic Church, Longridge. For many years he was the librarian at Stonyluurst. $\mathrm{He}$ is a somewhat cold and serious-looking man of about 60 , but he is exceedingly fond of old books and curiosities, and is a very clever and well-read man. He is fond of poetry, and I shall not soon forget his masterly exposition and elocutionary powers when giving a dissertation, some years ago, on Tennyson's "Elaine."

As a collector of old and scarce books, Dr. Boardman is well-known. He has succeeded in forming a large hibrary, which contains more copies of rare books than almost any private library in Laneasliire. Among these I may mention - folio edition of the "Mervarar Saga," in old Guthlandish and Swedish, 1671; editio prineeps 
(Greek and Latin) of "Archimedis Opera"" 1544; editio princeps of "Imitation of Clirist," 1468-75; Psalter in German (circa 1490); Scheible's curious collection "Das Floster weltlich and gcistlich," in 12 thick vols.; "Qudreria Medicea (early implessions of these engravings). The late $\mathrm{Mr}$. Bohn thought that his was the only private copy in England, complete; a goodly collection of Icelandic and Norse "Sagas."

Dr. Boardman has also a fine collection of engravings, chiefly on copper; and several of Bartolozzi's prints, and other scarce engravings. $\mathrm{H}_{e}$ alse possesses several fine paintings, bronzes, and other articles of vertút.

As a conversationalist, the Doctor can hold his own with anyone, and being, as I have said, exceedingly well read, he is a very formidable disputant.

It is greatly to be regretted that he should take no part whatever at present in public affairs, as during his year of office as a member of the Local Board he proved himself exceedingly useful, devoting himself to investigating the cryiug evils of the overcrowding question. But, after the disgraceful way in which he was treated, it is little wonder tbat he should have abstained from all public work. For his opponents-one of whom was a former colleague-in the election of 1884, raisel the cry of "No Popery," and turned a struggle about roads and sewers into one upon religion.

In politics he has taken rather a curious part. A strong supporter of Lord Hartington in 1880, he took little interest (apparently) in the election of 1885, although I have a dim suspicion that he was responsible fer the return of Lord Cranborne for the Darwen Division

He las worked hard to improve the position of his flock, and has succeeded in building a very handsome Church in Pitt Street, which was opened by the Bishop of Salford in 1886. As a preacher, Dr. Boardmau is very clear and connected, and, of course, logical. Commencing in a somewhat low tone, he gradually warms to his task, and enforces his arguments with clue solemnity, besides illustrating them with felicitous quotations from Shakespeare and other standard poets. $\mathrm{H}_{\theta}$ is quiet and undemonstrative when in the pulpit, relying eutirely on his roice to impress his hearers, which he undoubtedly does. 


\section{ALSTUN LANE CHUREH.}

The present chapel, called Alston Lane Roman Catholic Chapel, is about $1 \frac{1}{2}$ miles from Longridge on the high road to Preston. The old chapel, which was erected in 1765, was situated about 200 yards south of its present site

In 1857 the present neat and pleasing edifice, capable of holding 400 persons, was built. It is of the Gothic style of arehitecturo. The present priest is the Rev. Thumas Walton. The old ehapel, now used as a sehool, is attended by an average of about 80 .

The following list of the priests has been kindly given to me by $\mathrm{Fr}$. Walton. Priests at Alston Lane Chureh ' :-

$$
\begin{aligned}
& 1782 \text { to } 1785 \text {, Thomas Caton. } \\
& 1785 \text { to } 1814 \text {, Richard Edmondson. } \\
& 1814 \text { to } 1849 \text {, Richard ('owban. } \\
& 1849 \text { to } 1874 \text {, Hemry Sharles. } \\
& 1874 \text {, Thomas Walton, present Incumbent. }
\end{aligned}
$$

"The Rev. Henry Sharples," says "Attieus," "is a homely, quiet, fatherly gentleman, a good, genial, pre-eminontly fat priest, with a mind made ul of eontentment, and with a face with as much radiance in it as an oeean sunset. We should think he will be 4,000 ounces in weight. His height is in proportion to his weight. His brother was the late Rev. J. Sharples, coadjutor of Dr. Brown, bishop of the Northern Catholic District. Father Sharples is, for his years and size, an industrious priest, and to all he is kindly and courteous. He sits often whilst reading in church, and preaches short sermons."

The Rev. Thomas Walton, formerly at St. Ignatins's, Preston, is a fine, portly, old gentleman; and is much belored by his people. $\mathrm{He}$ is fond of literature, has an excellent library, and is very sociable and genial.

He preaches in a plain and homely fashion, and is listened to by his flock with mueh attention. He has an excellent choir, and generally a good congregation.

The other religions bodies having places of rorship in Longridge are the Independents and Wesleyan Methodists. 
THE INDEPENDENTS.

About the year 1860, the Rev. G. Scott, of Knowle Green, began to hold cottage meetings in Longridge, and as the attendance rapidly increased a room was secured, which came to be termed "The Tabernacle." In 1865 the corner stone of the present chapel was laid by Sir James Watts, of Manchester, and was opened for public worship in August of the same year. The cost of the building may be said to have been about $£ 3,000$, although the actual money spent was under $£ 2,000$-a large amount of free materials and free labour being given by members of the congregation. Mr. John Harrison, of Manchester, was also a very great friend to the church. The chapel is a neat stone building, with central gable, collateral turrets, and a large window in front. "Iuside its appearance," says Mr. Herritson, "is particularly clean and minutely spruce. The seats are strong, and no difficulty is experienced in sitting in them. The pulpit is massive, of tasteful design, and is approached on each side by a flight of steps. The members of the choir sing well. Their voices are good-good for Longridge." The chapel will seat between four and five hundred people. ${ }^{1}$ In connection with the chapel there is a good school, ${ }^{2}$ which had in 1888 an average attendance of 88.

The Rev. W. Booth was the first minister of the chapel, being appointed in 1866 . He is thus described by "Atticns," from whose very readable work I have so often quoted:

He is a young man, about thirty-eight, sharp, thinly-whiskered, white featured, slender, aspirates his initial letters well, combs his hair accurately, wears his hat towards his back, is a keen observer, very energetic, full of courage, enterprising, helieves in starting new movements, is tenacious, works hard, never gets into a real passion when preaching, but often touches the edge of one, speaks with regularity and earnestness, is

1Mr. and Mrs. John Crossley, the first couple married at the church, were presented with a handsome bible on the occasion of their marriage, a custom universally prevailing, I understand. in the Independent body on such a rare occasion.

${ }^{2}$ At the opening of the school on Oet. $23 \mathrm{rd}, 1 \$ 67$, the Riev. W. Booth referred to the kind friends who had so materially assisted them. "And I feel," he said, "that not a little is due -and I arn sure you will agree with me-to our friends who have belped us with the building, and more particularly to Mr. Jas. Tullis. I am sure - although I do not flatter-that from the beginning to the end our connection with Mr. Tullis in relation to tlis building has been one of mmitigated satisfaction, and I do not know that we could have been served with greater kinchess, courtesy, liberality, and efficiency." 
not too pious to laugh, can say smart things occasionally, and relishes a sally of good wit. He is a Manchester gentleman, served his time as a commercial elerk, then went to the Lancashire Independent College, and eame quite warm from that institution to Longridge in 1866. He was the first regular minister at the chapel, and has laboured most vigorously ever since his connection with it. Mr. Booth has considerable adaptability of character, and would be sharp at nearly anything. He understands cotton, bookkeeping, architectural designing, parsoning, and diver's other things, He designed the schoolroom, a capacions and excellently arranged builcling at the rear of the chapel ; he designed the new house, nearly opposite the chapel, in which he lives; he perhaps designed several other places for anything we can tell, and, as we told him the other day, may be called a very "designing" man. For his ministerial services he receives about $£ 120$ a year, and out of this he can save money.

Mr. Booth was not only an energetic minister of religion, but took also an active part in the promotion of the material welfare of Jongridge. To him, mainly, Longridge owes the possession of gas. A meeting was held in Nov., 1866, at which Mr. Booth took a prominent part. He took an active part in politics, and worked hard for the Liberal cause during the election of 1868 . He was very popular among the people, who were extremely sorry to lose him. MIr. Booth resigned the pastorate of the church in January, 1871, and was followed by the Rev. G. Price, who only stayed three yenrs.

The present respected I'astor' of the Independent Chapel, the Rer. H. Archibald, followed Mr. Price in 1875, and has, accordingly, been 13 years in the office. He was born at Coleraine, in the North of Ireland, but went, when young, to Glasgow, where lie lived some years, being engaged at a commercial house in the city. Then, for some years, he was in charge of the Manchester City Mission, where he did a good work. From Manchester he went, in 1868, to Milnrow, near Rochdale, as Independent Minister, at which place he stayed until he receired a hearty call to Longridge. He speaks with a Scotch accent, and is often taken for a Scoteliman. Te is a pleasant, elderly man, full of the milk of human kindness, and without any guile in him at all. He can bo plain and ontspoken when océrsion demands, but is a man of peace and quietness. He is perhaps best known as a model visitor of the sick and poor-work for which he seems admirably adapted. As a preacher he is soundly evangelical, indulges occasionally in diatribes against the Roman Catholic faith, and wages war against the sins and 
[ChaP. 2.

rices of modern life. $H_{e}$ is not a brilliant preacher, but he is very much in earnest. He lives a quiet, retired life, but is always ready to help on any cause for the public good.

THE WESLEYANS.

The Wesleyan Chapel was erected in 1884. It is a very compact, handsome building, in a mixed style of architecture.

Mr. Hewitson gives a good description of the old Chapel, "Mount Zion," built in 1836, now converted into a dwelling-house:- "The building has two circular-headed wiudows in front, and is elaborated with a conple of aged shutters. Internally it is simple, primitive and little, has about seven pews, six open rail seats, four forms, a stove, a pulpit, and a harmonium in it."

The new Chapel, erected in 1884, which is situated in Berry Lane, will hold about 400 people. Internally it is light, clean, and airy, and has a remarkably cleerful look about it. The seats are very comfortable. No regular minister is resident; supplies being sent from Preston every Sunday.

I ought, perhaps, to mention the fact of there being a few Particular Baptists in Longridge, who meet weekly in a cottage in the town. A supply is sent from Preston, I believe, every Sunday.

IRNOWLE GREEN CHUROH.

Knowle Green, a hamlet about two miles east from Longridge, has a handsome Indepeudent Chapel.

William Hayhurst, of Blackburn, whom my mother used to know very well, came here in 1829 , and finding the morals of the inhabitants were very bad, he commenced preaching in one of the rooms of Mr. Bond's mill, and soon afterwards a building used as a school and chapel was erected. Up to the day of his death, Hayhurst conducted the services liere, aud was buried here in 1857, deeply deplored and regretted by his flock.

In March, 1858, the present Pastor, Rev. Giles Scott, was appointed, and in 1866 the present Chapel, which will seat nearly 300 persons, was opened, the avernge attendance being about 200. The old Chapel is used as the school. "The Bishop of Knowle Green," as I believe Mr. Scott has designated himself, is one of the most hardworking men. 
in Lancashire. He is 75 years of age, but works harder than many a young man, being indefatigable as a visitor and as a money-beggar. Mr. Scott has done much good in his time, as through him the Independent Chapel at Longridge was opened, and the sturdy character of the people has been fostered and strengthened. He is a plain spoken, homely man, with a vein of quiet humour in him as he relates some of his begging interviews. He lives with lis daughter close to the Chapel, and we earnestly trust that he may long be spared to this locality.

The old Chapel, used as a school, is a neat building close to the Chapel. The average attendance is 78. Mr. Jesse Haworth, J.P., of Bowdon, and Mr. Thos. Rymer, of Manchester, have been generous friends to Mr. Scott in his work. The former gentleman, some years ago, gave the land for the present burial ground, which is also utilised by the Independents of Longridge. Lord Derby, Col. Bickerstaffe, and Misses Dilmorth have also helped Mr. Scott in his arduous work. Special mention slould be made of Mr. William Bomne, Radcliffe Cottage, Dilworth, who has been an excellent friend in time of need to the Chapel at Knowle Green.

Since writing the above, Mr. Scott has intimated lis desire to retire from the ministry, owing to failing health, although earnestly requested to hold on a little longer. But the venerable Pastor of Knowle Green is no longer what he was. Born in 1813, at Clitheroe, Mr. Scott was for some time connected with the Congregational Church in that town. Then he worked without fee or reward at Walker Fold for four years previous to coming to Knowle Green. We saw Mr. Scott a few days ago, and certainly noted a change for the worse in him, although he is just as cheery as ever. We can only hope a worthy man will be appointed to follow one who has worked so hard, and who has happily lived to see the fruits of his labours thriving like a green olive tree. 
CHAPTER III.-SOCIAL AND POLITICAT HISTORY.

Local Government, 1780-1820-1540-1868-Plan of Roads-Sanitary AuthorityFormation of Local Board, 1883 : First Election - Great Excitement - "Selling his frionds "- Result-Officers of Board-- Members--Rev. Dr. Boardman thrown out, 1851-- "No Popery" Cry - Election, 1887 - "Housemaid's Letter"-Work of Board - Sewerage rnestion: Wilful neglect-Births and Deaths, 1878-82: 1883-87-Inconsistency of Board-District Council-Broughton v. Longridge-Amounderness "wins the day "-"The Curse of Longridge"-Number of Inns-Poor Accommodation-The Remedy-Sobriety of People - The Co-operative Movement-Its rise and success-The Originators - Free Library-Friendly Societies-Facts and Figures -Floral Society -Debating Society-Lectures-Concerts-Cricket and FootballSt. Wilfrid's Dramatic Society-Volunteer Corps-Amateur Christy MinstrelsCongregational M. I. Society-Longridge in two Parliamentary Divisions-Ineonreniences and Absurdities-Remedies-Political Birth-Mr. Gladstone and Irish Church-1868 Election-Liberal Churchmen - Boycotting and Intimidation-1880 Election-Formation of Liberal Association, 1884: Its Work-Liberal Club opened by Irish M.P. - Ribchester Liberal Club - Chipping Liberal Club-Wrath of Tories -Conservative Club : Opened by Viscount Cranborne, M.P.-Its Work-Rihehester Conservative Club-Prinmose League-Free Tea Parties-Rev. C. O. Gordon and "his" school-Disorderly Liberal Meetings -Tory Tactics-"A Medium between God and the Devil "-Alderman B. Walmsley-Expnlsion of Tories-Quietness restored-Position of Parties - "Balance of power" in Dilworth.

The state of "Iocal government," to use a phrase then undreamt of in Longridge, from 1780 to 1830 or 1840 , has been described in as graphic a manner as possible in chapter I. How long the "select vestry" continued in office I do not know, but of course their "Poor" law powers" were taken from them in 1837, when the new Poor Law Act came into force. Probably "surveyors of highways" and "overseer's" were the guardians of the public weal-subject only to the nominai authority" of a "Town's Meetiug," held once a year. I have tried in vain to procure the minute books and other papers of these surveyors, ete., which I regret exceedingly, as there would be some interesting reading in them.

It has been said that the late George Whittle was the "Maker of Longridge," i.e., that he laid the foundations of its material comfort and wealth. In those days, from 1838-68, local government in Longridge was conspicuous by its absence. Men built houses, and laid out streets, etc., just as suited their interest and convenience. No regard was paid to public utility. True, as we have seeu, there were surveyors of the highway who were supposed to look after the interests of the place, but, with exceptions, these men were either tools in the hands of otllers, or rery easy-going persous. So that it is not surpris- 
ing, under such conditions, to find the streets badly lair ont, and that encroachments on the public highways had been made by various individuals

The plan of Longridge roads is by no means a bad one. From the north it is approacher by the ald highroar to Clitheroe, on the east by the highreads from Clitheroe and Blackburn, on the sonth by the highroad from Preston, and on west and south-west by the roads from Goosnargh, Whitechapel, Inglewhite and Chipping. On Longridge all these highroads converge, so that it may he said to be the natural centre for a large and important agricultural clistrict. ${ }^{1}$

Various attempts liad been made from time to time to improve the government of the town by means of Sanitary Authorities and Local Committees, but the efforts, though well meant, were futile, as the power of enforcing their decrees was lacking. ${ }^{2}$ At last things came to such a pass that an inquily was held by an Inspector of the Local Government Beard, with the result that Longridge (comprising the two tomnships of Alston and Dilworth) was created a Local Board district in 1883. The first election, which took place in April, 1883, created a vast amount of excitement. For the nine places on the Board no less than 18 candidates were nominated. Wliat was commonly known as the Party of Obstruction, imported into the contest a lot of personal embitterment, which produced one or two remarkable electioneering squibs, one of which was called "Selling his Friends." To these who knew the cliaracters depicted in this clever squib, immense amusement was created, as most of the hits were exceedingly lappy and full of the keenest satire. The Party of Obstruction retorted with rather a tame reply; but in aldition resorted to some very questionable means of influeneing the election So confident, in fact, were they of the success of their tactics that bets of 50 to 1 were freely offered by them that their men would win. Fabuluous sums of money

A glance at the map clearly proves the truth of this statement.

${ }^{2}$ In 1866 , at a public meeting convened to consider the gas question in Longridge, Mr. W. Marsden referred to the possibility of a Local Board; upon which Mr. W. Ascroft said : "Why not have a Local Board at once?" And yet Longridge was without a Local Board nearly 
were won and lost; and many bitter enmities were created by the result, which was a victery all along the line for the "Party of Progress."

The names of the elected candidates were:-

$$
\begin{aligned}
& \begin{array}{llllllll}
\text { James P. Whittle } & \ldots & \ldots & \ldots & \ldots & \ldots & \ldots & 756 \text { votes }
\end{array} \\
& \begin{array}{lllllllll}
\text { Henry Waring } & \ldots & \ldots & \ldots & \ldots & \ldots & \ldots & \ldots & 664
\end{array} \\
& \begin{array}{llllllll}
\text { Pichard Livesey } \ldots . . & \ldots & \ldots & \ldots & \ldots & \ldots & \ldots & 663
\end{array} \\
& \begin{array}{lllllllll}
\text { Robert Smith } & \ldots & \ldots & \ldots & \ldots & \ldots & \ldots & \ldots & 554
\end{array} \\
& \begin{array}{llllllllll}
\text { R. Howarth } & \ldots & \ldots & \ldots & \ldots & \ldots & \ldots & \ldots & 493 & \text {, }
\end{array} \\
& \begin{array}{lllllllll}
\text { E. Dewhurst } & \ldots & \ldots & \ldots & \ldots & \ldots & \ldots & \ldots & \\
\text { James } & \ldots & \ldots & \ldots & \ldots & \ldots & 491
\end{array} \\
& \begin{array}{lllllllll}
\text { James Tullis } & \ldots & \ldots & \ldots & \ldots & \ldots & \ldots & \ldots & 450
\end{array}
\end{aligned}
$$

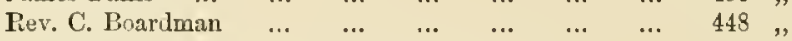

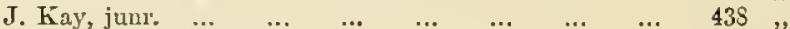

The following were the next on the poll :-

$$
\begin{aligned}
& \begin{array}{llllllllll}
\text { John Banks } & \ldots & \ldots & \ldots & \ldots & \ldots & \ldots & \ldots & 406, \text {, }
\end{array} \\
& \begin{array}{llllllll}
\text { William Bourne... } & \ldots & \ldots & \ldots & \ldots & \ldots & \ldots & 400,
\end{array} \\
& \begin{array}{llllllll}
\text { Arthur Whittle } \ldots & \ldots & \ldots & \ldots & \ldots & \ldots & \ldots & 400 \\
\text {, } & \ldots & \ldots & \ldots & \ldots & \ldots & 376,
\end{array} \\
& \begin{array}{lllllllll}
\text { Rid. Parkinson } & \ldots & \ldots & \ldots & \ldots & \ldots & \ldots & \ldots & 359
\end{array} \\
& \begin{array}{lllllllll}
\text { John } \operatorname{Jump} & \ldots & \ldots & \ldots & \ldots & \ldots & \ldots & \ldots & 310
\end{array}
\end{aligned}
$$

Mr. Rohert Snith was elected Chairman of the Board; Mr. James Jukes, Clerk; Dr. Eccles, Medical Officer of Health; Mr. J. Kirby, Surveyor (but was soon succeeded by MIr. James Bailey); all of whom retain the abcre positions.

Mr. James Tullis soon retired from the Board. In 1884, the Rev. C. Boardman was defeated, being most bitterly opposed by his former colleague, Mr. J. Kay, junr., by whom, or by whose supporters, the contest was turued into a religious one.

The elections since 1883, with the exception of the one in 1884 , to which I have alluded, and one in 1887 , have been very quiet. The contest in 1887 resolved itself into a semi-political one, and provoked a few squibs. Perhaps the most effective one was "The Housomaid's Letter." Much amusement was created by its quiet sative and allusion to well-known stories, which proved that the author was evidently behind the scenes. We think he mnst have laughed when lie found that some people actually believed that the letter was a genuine one. One individual actually wrote to the local press protesting against the unfairness of making public use of lost private letters. Truly the buccolic mind is often dense, and quite insensible to the force of delicate wit or satire! 
The following are at present members of the Board :-

Tobert Smith, J.P. (Manufacturer), Chairman.

William Adamson (Chemist).

William Bourne (Farmer and Innkeeper.)

Jolin Crossley (Shoemaker).

Jas. Dagger (Falmer and Bone Merchant).

Robt. Howarth (Farmer and Innkeeper).

Richard Livesey (Farmer).

James P. Whittle (Manufacturer).

William Fisher (Living Retired).

The Board soon turned its attention to some of the long-felt wants of the district, and in Nor., 1883, the streets were lighted with gas for the first time. Gradually the roads-long in a shocking state-began to be improved, some of the leading thoronghrares were flagged, streets widened by pulling down walls and setting hack houses, sharp curves and corners nicely rounded off, the famons old lamp erected on the site of the old Alston cross removed, and various other improvements made. Some attention was paid to sanitary matters, but the Board have deliberately fought shy of tackling seriously the sewerage question, and will continne, I suppose, with the usual forethought and wisdom of "city fathers," to postpone this question, fraught with such vital interest to the inhabitants, until some epidemic ol" other "visitation of God" compels them to settle it. It cannot be pleaded that the deathrate of Longridge is any better than formerly, as the following figures show:-

$\begin{array}{cc}\text { Year. } & \text { No. of Deaths } \\ 1878 & 69 \\ 1879 & 82 \\ 1850 & 60 \\ 1881 & 75 \\ 1882 & 88 \\ \text { Average, } 75 \text { per year. }\end{array}$

$\begin{array}{|cc|}\text { Year. } & \text { No. of Deaths. } \\ 1853 & 66 \\ 1584 & 90 \\ 1553 & 99 \\ 1886 & 63 \\ 1857 & 96 \\ \text { Average, } & 33 \text { per year. }\end{array}$

The birth-rate averaged 139 during tho five years 1878-82, and 130 during the last five yenrs, 1883-87.

This wilful neglect of a plain and obvious duty is rendered all the more glaring becanse of the arguments and facts about the state of the sewerage question in Longrilge, which were placed before the Government Inspector at the inquiry in 1883, and which had no doubt a great deal to do with the Local Government Board's faronrable roply to the petition for a Local Board. Mr. R. Finch, the then legal adriser 
of the petitioners, stated at the inquiry "that the condition of things was favourable to the propagation of epidemic disease, and that the Medical Officer of Health had in successive reports drawu attention to the unsatisfactory state of Longridge as regards its sewerage, and that if some measures were not talien to rectify this state of matters the result would be a severe epidemic, which would carry off a number of inhabitants." Mr. Finch also quoted the report, in which such terms as "scandalous" were used by Dr. Trimble with reference to the want of a system of serrerage in Longridge. At another meeting Mr. Finch stated "that he thought they would be able to get at the necessary sanitary work in three months from the formation of the Board."

In chapter I. we have seen how the people of Longridge in 1650 exaggerated their inconveniences in religious matters in order to add weight to their argument. The last statement of Mr. Finch looks very much like the "exaggeration" of the people in 1650 . Nearly six years have clapsed since the formation of the Local Board, and we are no nearer the solution of the sewerage question to-day than we were in 1883 .

Delays are, proverbially, dangerous. Aud in such a vital matter as this delay is more than dangerous-it is simply inviting an epidemic. Full credit is due to tho Board for the excellent work they have done, but in the words of a wise mau I would say- "these things ought ye to have done, but not to have left the others undone."

New offices for the Board have just been completed in the Market Place. The meetings, as a rule, have been quiet and orderly, the only complaint I have heard of being that there is "too much talk." But certainly the Board have done much, at a small cost, to improve the external appearance of Longridge, aud they deserve every credit for the way in which they have done their work. And if ouly they are supported by the inhabitants, we see no reason why Longridge should not become a favourite and popular health resort.

Perhaps I should here state that this Board will cease to exist in 1889 under the provisions of the new Local Government Bill; but, of course, the members will be eligible for the District Council. 
Some excitement lias been caused by a friendly squabble as to the name to be given to the district in which are Fulwood, Broughton, Longridge, Ribchester, Goosuargh, etc.

Longridge put in a claim for the houour, su did Fulwood, and so did Broughton, while Goosuargh and Ribchester seemed to be out of the running entirely. I liare heard a good authority, however, suggest that the district should be called after Ribchester, but the grounds of my informant's claim are to my mind very fallible. Why the district should be called Broughton-as it was provisionally-it is hard to comprehend. Its claims, when compared with those of the other tomnships, are simply ridiculous. The claims of Fulwood and Longridge are apparently very erenly balanced. The populations in 1881 were practically the same, but the character of the two populations is very different. In Longridge the well-to-do cotton weavers form the backbone of the place, while the Fulwood population is largely made up of paupers and soldiers. And further, as Mrr. Jukes, the Clerk to the Longridge Local Board, pointed out at the recent conference, "within a radius of three miles of Longridge they had a population of 9,245 out of 17,050 , which is the entire population of the whole electoral district." But there are other considerations to be borne in mind in dealing with the cuestion of "names." And they are quite as important as any that have been already" mentioned. In the course of a few years Fulwood will undoubtedly be merged in the borough of Preston, to share, as Mr. G. Dixon somewhat viciously observed, in bearing the cost of the "Quicotic Ribble scheme." Whilo on the other hand it is equally probable that within a short time the adjoining townships of Goosnargh, Ribchester, etc., will be amalgamated with the Local Board district of Longridge. And at the same period will be formed a Petty Sessional division for the district I have mentioned. ${ }^{1}$

One thing must be done, however, before Longridge will become a popular health resort. A great change must take place in the management of the Inns and "Hotels." There are thirteon Inns and five Beershops within the Local Board district,

'Since the above was written the district has received the incomprehensible name of "Amounderness"-part of the district being in the Hundred of Blackburn! 
and it is therefore little wonder that none of them are better than ordinary third-rate Iuns. With diffieulty a dish of ham and eggs can be procured at the leading hostelries by giving long notice, while often bread and cheese are all you can procure. Such a state of thiugs is simply a disgrace, not only to the owners and keepers of the Inns, but to those who patrouise them. The remedy lies with the public. Only let them "send to Coventry" those Innkeepers who refuse to make ample provision for travellers and visitors, and the thing will be done. Clean and cheerful hotels will replace the present dirty and squalid-looking drinking shops, and publican and the public alike will be gainers. But Longridge people are by nature obstinate and fond of old ways, and we shall be surprised when any change for the better does take place.

Drunkemness is almost uukuomn in Longridge-a change which has taken place in the last 10 or 12 years. To what it is clue $I$ hardly know. Certainly the Temperance Societies have worked hard, but I should say thrift and prudence, which have been fostered by the Co-operative principle, and the Friendly Societies, are chiefly responsible for this gratifying improvement.

The estabhishment of a Co-operative Store in Longridge in 1874 has completed the work begun by the late George Whittle. A brief sketch of the Co-operative Society is interesting:-

The following five persons, viz., Isanc Willkinson, James Pye, Wm. Waring, Thomas Coupe, and Henry Slinger, originated tho Society in Messr's. Waring Bros.' quarry. A meeting was called by them, at which about 30 people attended. The result of this meeting was the appointment of a Committee, to make inquiries prior to the formation of the Stores. Soon after the Society was formed, 20 members joining; tro cottages in Fell Brow were converted into a shop, the Committee acting as salesmen at nights. From such a humble start did the present wealthy Society spring. The shopkeepers were alarmed, but comforted themselves with the assurance that, "it could not succeed." The Society was Registered on March 24th, 1874, and in 1875 a branch Store was built in Pitt Street. In 1880 the Central Stores were built, the coruer stone being laid on May 24th, 1879, by Mr. 
Pobert Smitli. In 1886 a second branch Store was opened in Lee Street. During the present year (1888) the Central Stores have been enlarged, and now form a huge block of buildings, 100ft. in length, $80 \mathrm{ft}$. wide, and $60 \mathrm{ft}$. high. The first year's sales were $£ 1,800$; the sales for 1887 wer $\theta$ no less than $£ 17,000$. The present number of members is 722, while there were only 146 at the end of 1874 . The divident paid is 2s. 21. in the ponnd on member's' purchases, and 1s. 1 l. on non-members' purchases. The enpital now stands at $£ 7,338$.

In connection with the Society is a Savings Bank, and a Reading Room and Library, free to members and their children. A grant of $2 \frac{1}{2}$ per cent. per annum on the profits is made to the Librnry, which in 1887 amounted to $\mathfrak{E} 40$. Originally, lectures were given under their auspices, a work taken in hand by the Debating Society in 1881. There are two large lecture halls in the huilling, which will seat abont 1,500 people.

Nothing but praise ean be bestowed on the Suciety and its Managers for the great and good work they liave accomplished, and we are sure that thonsands to-day bless the date of its foundation.

To its founders, all working-weu, the Society is largely indebted for their wise counsel and hard work

Among other kindred institutions, the Friendly Societies, of which there are seven in Longridge, must not be forgotten. For the subjoined facts and figures I am indebted to the Secretaries of the various Lodges. The oldest Society is the Independent Order of Oddfellows. The "No Danger" Lodge was openerl at the White Lion Inn, Hothersall, on Dec. 25th, 1840. The Trustees aro the Rev. F. A. C. B. Cave, M.A., P.G. George Banks, and P.G. Robert Booth. The Officers are, G.M., IV. A. Parkinson; N.G., Jno. Bamber; V.G., Jno. Ormerod ; Ass. Sec., John Eecles; Perm. Sec., John Parkinson, Severn Street; Treasurer, Robert Howarth, Dog Inn. The number of nembers on Jan. 1st, 1888, was 212; the amuunt of funds $£ 97+19 \mathrm{~s} .5 \frac{1}{2} d$. The Lodge meets monthly at the Dog Inn.

The United Order of Catholic Brethren, Blnckburn Unity, St. Peter and St. Panl, Alston District, was established in 1844, at the W'hite Bull Inn, Alston. The first officers were, Thos. Wilkinson, President, 
William Whalley, Secretary, Thos. Wilkinsou, Treasurer. Mr. Thos. Woods, however, acted as Secretary for 21 years. About 1850 the Society was worth $£ 12$, and had 35 members. In 1864 it was worth $£ 40$, and had 40 members; in 1866 the funds were as low as $£ 9$; but in 1874 the Society was worth $£ 273$; and in 1887 the funds wer $\theta$ $£ 852$, and the Society had 133 members. The benefits are: Sick Pay, 10s. weekly for six months, which is reduced gradually to $2 / 6$ a week; Fuueral Pay, $£ 8$, and $£ 6$ on death of a member's wife. The present officers are: John Nicholson, President; Jas. Tipping, Vice-President; Hy. Wearden, Warder; John Tipping, Secretary; Jas. Coupe, Treasurer; aud Thos. Woods, Chief Treasurer for the Unity. The Society meets at the Bull and Royal Hotel

The third Society founded in Lougridge was the Grand United Order of Oddfellows, on July 3rd, 1850. The capital is $£ 203$; the number of members being 72 . The officers are: James Hesmondhalgh, N.G.; John Slater, V.G.; J. T. Dewhurst, P.N.G.; Joshua Hall, Secretary.

The Longridge Indepeudent Sick aud Funeral Society was started on November 2ud, 1867. The unmber of members then was 49. The officers were: David Crossley, Chaiman and Treasurer; Saml. Seddall, Secretary. The present number of members is 39 ; the funds amounting to "about $£ 200$." The benefits appear to be: Sick Pay, from 10s. to $2 / 6$ per week; Fuueral Pay, $£ 10$. The present officers are: Trustees, Rev. H. Archibald, J. Halsall, and D. Crossley; Presideut, D. Crossley; Vice-President, Johu Crossley; Secretary, John Campbell. The Society meets in the Congregational Schoolroom.

The next Society established was the Ancient Order of Druids, Lodge 349, which was opened May 15th, 1852. Samuel Roscal was the origiuator. Fourteen members joined the first year. Iu 1887 the number' was 200 . The funds amount to $£ 95314 \mathrm{~s}$. 6d. The beuefits obtained are: Sick Pay, 9s. per week; Funeral Pay, $£ 8$ on death of member or member's mife. No persons over 40 years of age are allowed to join the Society. The officers in 1852 were Richard Bamber, N.G.A.; John Rawstorne, V.G.A. ; John Livesey, Secretary; and T. H. Sargensou, Treasurer. The present officers are: Ed. 
Bamber, N.G.A.; John Counsell, V.G.A.; James Roper, Sccretary; are T. Flctcher, Treasurer. The Lodge meets at the Townley Arms Hotel.

The Mechanics' Club, "Pride of the Village Lodge," was formed on May 9th, 187t, at the instigation of R. Capstick. The number of members the first year was 19. Its first officers were: R. Capstick, J.G. ; T. Airey, D.M. ; John Jones, S.D.; T. Cotton, P.S. ; Isare Vilkinson, P.T.; J. Hawthornthwaite, O.T.

The Lodge is worth "close upon $£ 300$;" the number of members is 130 . This is the only Society in Longridge which gives permanent sick pay, according to the degrees taken up. This varies from 6s. to 9s. a week permanently. Ten pounds is paid on the death of a member, and $£ 6$ on the death of a member's wife. The present officers are: Isaac Wilkinson, J.G.; John Pinder, senior, D.M.; John Pinder, junior, S.D. ; Thomas Cotton, P.S.; Richard Seed, P.T.; Thomas Sharples, J.T.; R. Marsh, O.T. The Sôciety meets at the Red Lion Hotel.

"The Star of Temperance Tent" of the Independent Order of Rechabites was formed in $\mathbf{1 8 8 1}$, chiefly through the exertions of $\mathbf{J}_{\mathrm{ohn}}$ Campbell. Commeneing with ten wembers, the Society now has 60 members. The original officer's were: T. Carefoot, C.R.; IV. H. Innowles, D.R. ; John Pindor, treasurer; W. H. Pinder, sceretary. The amount of funds is now $£ 10+19 \mathrm{~s}$. $8 d$. The benefits vary from $2 \mathrm{~s} .6 \mathrm{~d}$. to 15 s. a week for sick pay, and from $£ 5$ to $£ 30$ for funeral pay. The present officers are: W. Ryding, C.R.; H. Greenwood, D.R.; W. Kay, treasurex; and J. Campbell, secretary. The Society meets in the Board Room of the Co-operative Hall.

An allusion has been made to the Floral Society, which was formed in 1878, and is still flourishing, its elcventh annual show, held in 1888, having proved a success.

The Longridge Debating Society, formed in 1881, came to a temporary end early in 1887, orving to the lack of interest taken in its proceedings by the members, and to the deternined hostility of a section of its members. During the six years it existed much good had been effected through its agency. In connection with this Society, 
lectrues are still delivered annually by leading men of science, etc. Duriug the last five years lecturos have been delivered, under its auspices, by such men as the Rev. Father Perry, S.J., F.R.S.; Archibald Forbes, IL.D.; the Rev. Jonathan Shortt, B.A.; R. W. CookeTaylor, Esc., H.M. Inspector of Factories ; and others.

A number of coscerts and other entertainments are generally got up during the year-the large lecture room in the Co-operative Hall being able to seat 800 people. A Cricket Club also exists, but is, we fear, in a rather moribund state; while football flourishes in Longridge as it does now-a-days all over Lancashire. The youth of the district are, however, sadly in want of a playground; and it is to be hoped some generous friend of the placo will supply the deficiency at an early date. In connection with St. Wilfrid's Roman Catholic Church there is a promising amateur theatrical company, who usually give one or two perfornances every year. A Volunteer Corps was at one time in existence at Longridge; and it is greatly to be regretted that an effort to resuscitate such a desirable institution has not been made. There are, we feel quite sure, plenty of strong, young men who would be only too glad to join.

The Longridge Amateur Christy Minstrels annually give their excellent performances during the winter months. There is also a flourishing Mutual Improvement Society in connection with the Independent Church.

For political purposes, Longridge is split up into tro divisions, the two tornships of which it is composed being in different divisions of the county, and in different hundreds. Alston is in the Amounderness Hundred and in the Blackpool Division, while Dilwortl lies in the Lower Blackburn Hundred and in the Darwen Division. ${ }^{1}$ The boundary line runs through the Dog Inn, which hostely'y is therefore in two divisions. The effect of this state of things is curious and inconrenient. A man gets drunk in Dilworth; he is summoned to Blackburn; if in Alston, he las to go to Preston. Aud, to take a political instance, a householder lenving his house at one end of the

1'The vosition of the township of Thornley is very amomalous. It is in the. Clitherne Huudred, in Chipping
Parish, and joined to Longridge (Dil worth) for Parliamentary purposes. 
Market Place for the other end is disqualified as a voter, for two year's in some cases. Many police cases aud the like are looked over on account of the difficulty and expense caused by this "old time" state of things. Hothersall, too, is in the same extraordinary position as Thornley. It is joined to Longridge (Alston) for Pa-liamentary" purposes, is in Ribchester Parish, and in th 3 Hundred of Blackburn. In both these cases the boundary lines, as in the case of Alston and Dilworth, are merely nominal.

Attempts have been made from time to time to remedy this division, but hitherto without results. The Local Board suggrested, with but little enthusiasm, a Petty Sessional division being formed at Longridge; while the Libernl Association of Longridge prepared evidence and petitioned the Boundary Commissioners, in 1884, to throw Dilworth along with Alston into the Amounderness Hundred and Blackpool Division, but the Commissioners replied non possumus pleaded they had no porrers.

Politically speaking, Longrilge was born in 1866. It then had 73 roters on the register. The Alston voters voted at Alston; but the Dilworth voters had to go so poll at Ribchester. As if by magic the people of Longridge were emakener from this state of political torpur and their passions roused to fever heat by what the vast majority deemed Mr. Glarlstone's blasphemous proposals to disestablish and disendow the Irish Church. The writer well remembers hearing over and orer again the story of what Longridge did during that election (1868). To beignorant of the fact that two-thirds of Longridge people at that day were Clureh-people first and politicians afterwards is to have failed to grasp the keystone of the character of Longridge people. They were filled with an intense (if somewhat blind) feeling of attachment to the Church as a pulitical (or State) institution. The writer can understand (from his own experience as a Churchman), if he cannot sympathise nuw with, such a feeling. In this state of thing's then, to be a Libernl wis had, but tu be a Churehman and also a Liberal was something that could not be unlerstood. Many minds were not brond enough to conceive such a condition as this, and so against the few aud solitary Liberal Churchmen, notably Mr. D. Irrin, 
J.P., the full wrath and hatred of the Tory Churchmen burst forth. Not content with insults and assaults, they carried their politicoreligious feelings into the Church itself, and by the display of party colours, and by open and umrebuked sneers and jeers tricd to drivo their cnemies away. Wounds were made then which have not been healed since. Boycotting was openly practised; boys and girls were taught to throw stones and ugly words at Liberals as they passed through the streets, and so well did they do their work that for nearly 20 years after Liberals were almost afraid to a

But it was only at election times that the majority of the people of the district took any but a faint interest in politics. They were part of "the great residnum," and had no vote.

In 1880 when Lord Hartington and Mr. Graften won N.E. Lancashire from the Tories, there was some little excitement-but beyond some friendly foolery, such as using epponents' cabs and eating opponents' dinner's, Longridge was fairly quiet.

But in the winter of 1883 , on the eve of the settlement of the County Franchise question, a movement was begun by the present writer which has had the effect of stirring up both political parties six miles round Longridge somewhat to a sense of their proper political duties. This movement was the establishment of a Liberal Association under the title of "The Longridge and District Liberal Association," an organization which undertook to look after the political education and registration affairs of the following townships:-Alston, Dilworth, Chipping, Goosnargl, Hurst Green, Ribchester, and Whittingham. It was formally constituted in Jamnary, 1884, amid every encouragement. Its officers were:-Presilent, Thomas Rymer, Esq.; vicepresidents, J. P. Whittle, Esq., D. Irvin, Esq., J.P., T. H. Rymer, Esq., and W. A. Winstanley, Esq.; chaiman, Henry Waring; hou. secretary and troasurer, Tom C. Smitl. From the records kept by the Association I take the following facts and figures which abundantly testify to the efficicncy and usefulness of such a body.

Lectures: 1884, eight; 1885, fourteen; 1886, one ${ }^{1} ; 1887$, eleven. These lectures wero delivered on almost every subject of current

${ }^{\mathrm{T}}$ The general election and a byeelection which took place in this year account for the only solitary lecture being given. 
political import, and were given by men of every trait of character and position, and took place in every village and hamlet six milos around, and would probally average an attendance of 250 .

Many hundreds of thousands of pamplilets have been distributed, besides which the Association has published four trats written by the Hon. Secretary. Numerous debates and otber social meetings have been held, a comfortable and conmodions Club established, and to-dlay the Association probably has a membership of over 300. The Club had the unique distinction of bcing the first Liberal Cluh opened by an Irish Nationalist M.P. (Mr. John O'Connor, M.P.)

A Branch Clnb-now independent-was also established at Ribchester. Another opened at Chipping was soon elosed, owing to the poor attendance.

The writer will not soon furget the reception this bold and audacious movement met with from both friends and foes. Cautious Liberal friends were frightened, the Tories could not understand it, for was not Longridge, as the Herald in a leading article some yoars after said, "the backboue of the constitutional cause?"

Ceasing to be blindod with stupor, the Tories, on their recovery, reeognised the importance of what had heen done, and with a courage born of something like de spair resolved to reeover the ground their confidenee had temporarily lost them. A Conservative Association was formed, and it was decided to build a club. Malf of the share capital, $£ 1,500$, was subscribed. The officers are, R. Smith, Esq., J.P., chairman; F. Openshaw, Esq., J.P., vice-chairman; hou. treasurer, Mr. Fred. W. Smith. The elub is a plain but very commodious building in Berry Lane, and is handsomely furnished. There are two billiard rooms, reading room, and office, besides accommodation for the sterrard. There is also a Conservative Club at Ribchester. Connter meetings were held, but more dependence was placed upon the policy of meeting arguments with howls and groans, and trying to stop the mouths of Liberal lecturers with noise and foree. ${ }^{1}$ For some time Longrilge became notorious for its noisy disorderly Liberal meetings. One meeting in particular, held in

\footnotetext{
${ }^{1}$ "In 1768, during the memorable election at Preston, Longrilire, Ril,chester, and theneighbourhood furmished 
July, 1884, and which was addressed by Messrs. Eli Sowerbutts, R. C. Richards, and J. C. Feilden, leserves mention. I quote from the account in the Preston Guardian, which was written by one of the smartest reporters in Lancashire. The room was crowded, and numerous worly encounters took place between Liberals on the platform and Tories ensconcer in the back of the hall, amongst whom were Mr. Alderman Walmsley. Mr. James Kay, senr., created a lot of amusement by delivering several weighty aphorisms during the comrse of the evening. Just about the noisy part he emphatically declared that his opinion was that the House of Lords was "a medium between God and the Devil." Mr. Walmsley made a ratthing speech, in which he called Mr. Gladstone a thundering liar, and asserterl that John Bright had ransacked the Scriptures from Genesis to Revelation for denunciatory expressions. The way in which Mr. Walmsley thumped the table as he came out with his remarks was most astounding, and will not soon be forgotten. The chairman, Mr. Hemry Waring, distinguished himself by acting in as cool and sarcastic a manner as possible, declaring, amid loud laughter and cheers, and indescribable confusion, shouts, and catcalls, that the Liberals had carried their motion condemning the Lords by a majority of udult rotes.

Of course, such conduct persisted in without the shightest just cause brought a good deal of "moral" dis grace upon the local Tory party, but as some of the leaders mere chiefly responsible no official rebuke was administered. At last matters culmimated at a meeting of the electors held at Longridge in July, 1886, in support of Mr. John Slagg's (now M.P. for Burnley) eandidature. So uproarious were the proceedings that a few of the Liberals determined with the aid of the police and some friends from Darwen to eject the disturbers. I shall not soon forget the utter dismay and alarm which I saw depicted on the faces of certain well-knomn Tories as they found that they were gradually being forcibly expelled, despite their desperate struggles. So effective dil this lesson prove, that from that day to this no Liberal meeting in this district has been in any way disturbed beyond the usual interinptions, which ouly add zest to tho proceedings, and end in affording the speakers an olportunity of malking one or two good "points." 
The work done by the Tory party in Longridge is chiefly confined to general elections and to furthering the Primrose League. Certainly they work well at elections, sometimes a little too well. The Cranborne and St. Michael Habitations of the Primrose League are both, I understand, in a flourishing condition. Occasionally they give free tea parties and concerts, and sometimes practice a little boycotting. Their action at Whittingliam Asylum has beon not altogether fair, but they are well watched, and will not, wo think, go too far. One littlo fact deserves mention, as it illustrates the casuistry of Church of England Tory parsons. In 1884 I made application to the Rev. C. O. Gordon, Vicar of Goosnargh, for his consent as a trustee for the use of the school there for a Liberal meeting. In a very fair letter he declined my request, promising to allow no political meetings therein except at election times. In 1887 a meeting of the Primrose Lengue was held in the School, and a vote of thanks at the close was tendered to the Vicar for his kindness in lending the school. At the meeting attempts were made to hicle its political character, but I wrote to the Vicar for an explanation of this violation of his roluntary promise, and asked him if the Primrose League was not just as much a political body as the National League. I received the following reply:- "I beg to acknowledge the receipt of your letter.-I am, etc., C. Oshorne Gerdon," which, of course, amounted to a tacit admission that I was right.

The number of voters for Alston on the registers is 300 , and for Dilworth 440. The probable voting strength of the three political partiesis-Tories, 440 ; Liberals, 300 ; "Unionists," half-a-dozen, which approximate very closely, it will be observed, to the strength of the Church and non-Church people.

The large majority take a keen and intelligent interest in politics, and, where not blinded by prejudice or passion, are exceedingly well informed on the leading topics of the day. It is to be feared that the love of the "green cloth" which has sprung up during the last three or four years is proving stronger than the love of reading for the younger generation. Politically speaking, Longridge is of vast importance to the Dartren Division, as the balance of porrer may be said to lie in Dilworth. Both Lord Crauborne and Mr. J. Gerald Potter recognized this in 1885; and the Longridge Tories do not forget it. 
[CH.AP. 3.

As for Alston, it is not of much consequence politically, except locally. Mention should be made of the sturdy Liberalism which exists in the Knowle Green and Ribchester district, as it is in bright contrast to the somewhat timid Liberalism generally prevalent in the Longridge and Goosnargh districts. 


\section{CHAPTER IV.-LOCAL CELEBRITIES.}

William Walker-John Eastham-Fanny Smith, a centenarian-William Corbridge-Rev. W. Fisher - William Buck-Thomas Fleming-George Whittle, "the maker" of Longridge-William Marsden-Robert Smith, J.P.-William Smith-James Gregory-12. H. Lightfoot-Janes Dilworth-Robert Ascroft-H. B. Jones-Dr. Eccles, senior-Harry Eccles-Dr. F. Eccles-IV. Pestwich-Henry Hoole-R. B. Dixon-James 'I'ullis-Dayid Irvin, J.P. - David Nuttall-Grace Watson-George Banks-John Banks-Alderman B. Walmsley._Loeal A uthors: IV. Cottam, the poet-J. Halsall-J. Catlow-Rev. Charles Boardnan, D.D.

William Waliegr.

"At the Church of Ribchester was interred, in all probability, the last survivor of all who had borue arms in the war between Charles $\mathbf{I}$. and the Parliament; for in the Parish register is this entry :- '1736, Jan. 13th, burried William Walker, a cavalier, aged 122, de Alston.' This man had a horse killed under him at the Battle of Edge Hill; how long he retained his mental faculties I do not know; if nearly to the close of life he must have been a living chronicle, extremely interesting and curious."

\section{Jorin Eastimay.}

"On Sunday, Sept. 28th, 1826, died at Longridge, Mr. John Eastham, aged 46 . He was an out pensioner of Chelsea Hospital, having been a Sergeant in the Rifle Brigade, and fought at the Battle of Waterloo."

\section{Fanny Suitir.}

"On Aug. 31st, 1826, died at Inglewhite, Mrs. Fanny Smith, aged 101, mother to Mr. H. Smith, of Preston. She was living in York at the time the Duke of Cumberland passed through that city on his return from the Battle of Culloden, and assisted in cooking the dinner of which H.R.H. partook."

Williay Corbridge.

"William Corbridge, died Nov. 21st, 1826, aged 39. Served in the Rocket Brigade at Waterloo."

Rev. Williaji Fisier.

"Nov. 1st, 1813, died at Stydd Lodge, Ribchester, aged 84, Rev. William Fisher, Catholic Priest. The reverend gentlemen was at Lisbon at the time of the great eartliquake there, 1755."1

${ }^{1}$ From "Preston Chronicle." 
Williay Buck.

"On Saturday, Aug. 11th, 1827, the death of William Buck, Esq., aged 42, took place at Alston Lodge, Longridge. Mr. Buck was a gentleman much esteemed by the inhabitants of the village of Longridge and its vicinity, on account of his exertions in regulating the affairs of the poor; and in rendering every possible assistance to all the industrieus and deserving cottagers throughont the district in which he resided. His early death is consequently a subject of deep regret to all the neighbourhood."--" Preston Chronicle," Aug. 18th, 1827.

Mr. W. Buck was born in 1785 , and was a son of the Rev. Charles Buck, M.A., Vicar of Goosnargh and Lund. Mr. Buck filled many public offices in Longridge, being Chapel Warden, and Chairman for many years of the "Select Vestry" of Alston. Mr. Buck married Miss Quartley, daughter of the Vicar of Ribchester. He built Alston Lodge, where he resided until his untimely death. He was a connection of the well-known lawyers, Messrs. Buck and Dickson, Preston.

As is recorded in Chapter I., the Preston and Longridge Railway was opened on May 1st, 1840. It was built for the purpose of developing the stone tracle in Longridge. So some account of the pioneers in this trade will be necessary to complete the history of Longridge. The first quarry of any size in Longridge belonged to, and was worked by, Thomas Fleming, whose name survives to-day in "Fleming's Quarry," worked by Messr's. Waring at present.

Thomas Flemixg.

On Sunday, May 26tli, 1861, died Mr. Thos. Fleming, whe may be fitly termed "The Father of Quarry Masters." I have gathered many particulars of Mr. Fleming's life from men who knew him very well; but such an able sketch of his life was written by the late Mr. J. Halsall at the time, that I am sure I cannot do better than largely quote therefrom. "Mr. Fleming," says Mr. Halsall, "was more than forty years ago (1821) rather extensively engaged in supplying from his quarry these large blocks of freestone for such public works or buildings as were then in course of erection or formation. Alent this period, or, at all creuts, soon after, he had the good fortume to become 
the purchaser of that part of the Tootle Height Estate which lies beween Spencer's Delf (now Cooper anil Tullis's) and Tommy Konyon's cottage. He also made the acquaintance of the late Mr. Jesse Hartley, the talented and able Surveyor of the Liverpool Dock Company, with whom Mr. Fleming did a very considerable business. Many colossal blocks were conveyed from Mr. Fleming's quarry to the docks at Liverpool. The enterprise and perseverance of Mr. Fleming could, perhaps, never be placed in so favourable a light as at that period. There were no railmays to connect the distant town of Liverpool with a remote village, and the only mode of conveyance tras by means of horse locomotion. The thing seemed disheartening. Notwithstanding" this, however, the traffic was carried on in a satisfactory manner." Mr. Fleming had also other large contracts, owing to the great fame of Longridge stone." The quarry, which is called after his name to this day, was well and industrionsly worked by Mr. Fleming for nearly half a century. "Mr. Fleming," contiunes Mr. Halsall, "might be said to be peculiar in his habits. He cerer intrusted the inspection or superintendence of his workmen to anyone. Hence it was, that when gentlemen from other towns, architects, builders, contractors, and others, required to sec him, it was common enough for them to find him working array in the rock, or at the crane, utterly undistinguishable from the other men employed under and around him. A suit of clay-coloured trowsers or breeches, and a pair of clogs, was often enough the garb in which he has been found by somo of the wealthiest and most talented men of the day." He had a wonderfully strong coustitution; and considering the deleterious nature of a quarryman's employment, one is struck with the fact that Mr. Fleming should have lived to the patriarchal age of three score and ten. And, moreover, he had no common troubles of a private nature to endure. His early career was blighted and his life chequered by the death of his chilliren. "Little more than thirty years ago," says MIr. Halsall, "he could boast of as fine a family of sons and daughters (rear a dozen) as could be found "in a day's mareh." All died, some of them in early manliood and womanliood, little more than a year before 
the father. He had also lost both his wives. He was a keen judge of talent in his men, and often the poor pretender to ability, or idle and careless workman, would receive some cutting sarcasm or stinging appellation which would stick to him through life. In politics, Mr. Fleming was a Tory of the old school, but he did not take much active part in political work. He was one of the promoters of the Longridge Railway. I have been, however, informed by people who kuew Mr. Fleming very well, that he was rather tyrannical in his dealings with his workmen. He only paid them small wages, besides compelling them to patronise his "Tommy shop," where they obtained groceries, etc., at about 35 per cent. only above ordinary shop prices.

But in this latter respect, it is only due to Mr. Fleming to say that he was little better or worse than most of the other Longridge employers of his day. Mr. William Marsden, Mr. T. Spencer, and Mr. J. Fletcher, all kept "Tommy shops." Nor should we, who live in better days, blame them, uutil we ourselves are more just towards our fellow-men.

We conclude this sketch of Mr. Fleming's career by saying that the people of Longridge ought never to forget one who worked so hard and so successfully, as assuredly did Mr. Fleming, to raise Longridge from being an obscure and insignificant village to a position of note in the stoue trade.

\section{George Whittle.}

Just about a year after the accession of Queen Victoria to the throne, viz., in 1838, there came into Longridge a young man whose name is not likely to be forgotten in a place which owes to George Whittle, more than to any one man, the foundations of its material prosperity. We have seen in Chapter I. what was the probable condition of Longridge in 1838, and we have seen what it was when George Whittle died, at the early age of 51 , in 1865

George Whittle, the subject of this sketch, was born at Withnell in 1814. His father was a hand-loom manufacturer, and employed several "putters out." A "putter out" was a manufacturer who put out work to hand-loom weavers. When quite a youth he went into the business of Joln Lightfoot, a draper in a large way of business at Mauchester, where he did not stay long. Then for some little time he 


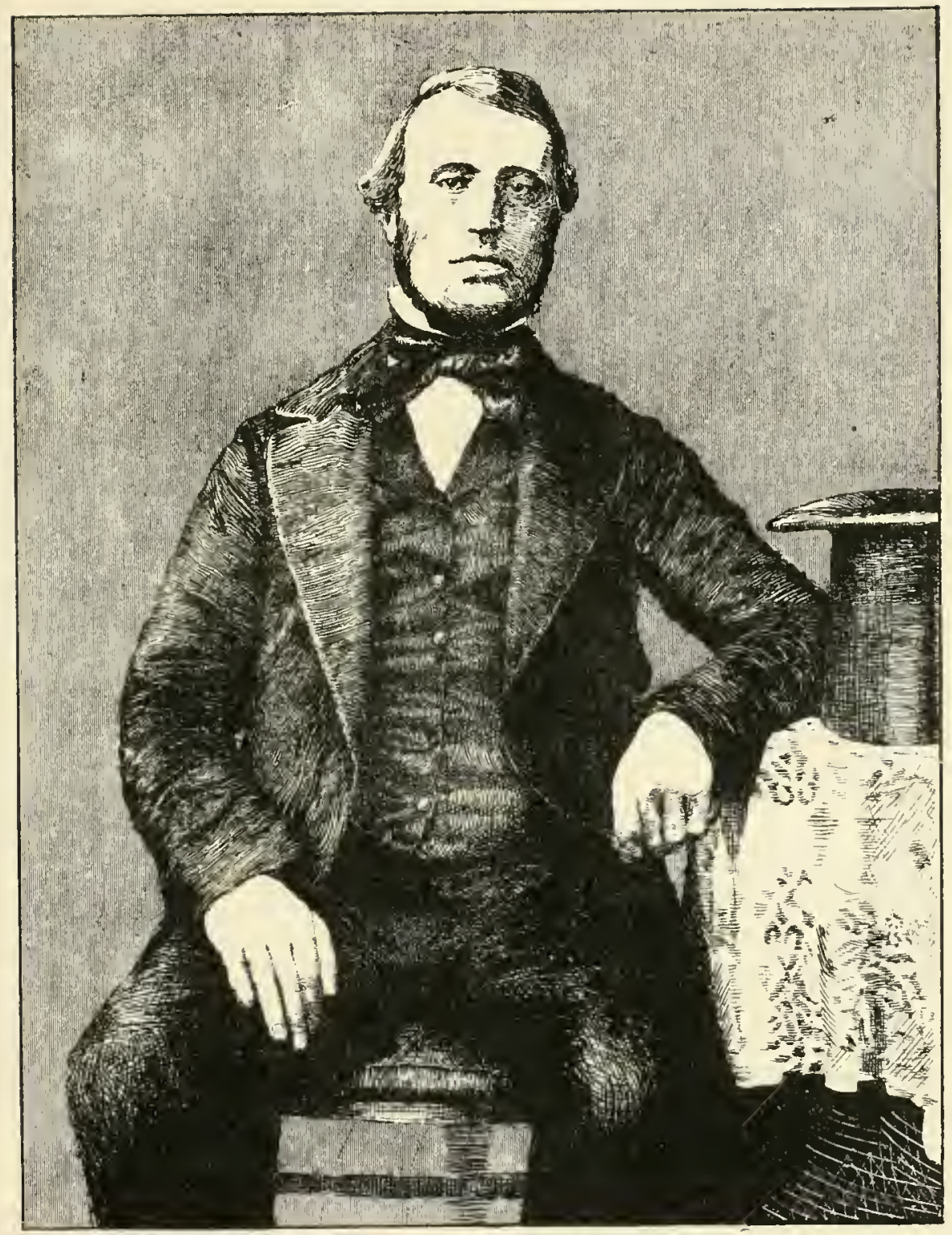

Eastos a sunele siane 5

THE LATE GEORGE WHITTLE, ESQUIRE. 

was in Manchester picking up useful information from Rolert Milner about the cotton trade, for inte that business George Whittle had determined to go. Fate, however, very nearly kept him away from the scene of his struggles and future success. He was invited to go out to Australia with George Milner, and but for financial reasons would have gone. Eventually, in 1838, he came to Longridge as (what was called) a "putter out" for mercliants. At first George Whittlo was in partnorship with Mr. Hayhurst, of the firm afterwards callerl Hayhurst and Marsden; but the partnership was not a snecess, and soon became the master of a number of workshops or hand-leom colonies on his own account. They were at "the old workhouse," Longridge, now turned into cottages in Fell Brow, Hurst Green, Goosnargh, Ribchester, and Copsterd Green. To most of these places George Whittle would walk once a week, generally starting at night or early in the morning, and after doing a hard day's work, walk back at night. This was serere work, indeed, killing work; for it is related of George Whittle that, when on his deathbed, he told R. H. Lightfoot that " if he had it to do over again he would not walk to Newton and back (some 15 miles from Longridge) for untold wealth." The conditions of the cotton trade at this time were just the reverse of what they are to-day. Then it was not a question, as it is now, of workpeople finding work, but of the masters funding workpeople to execute their orders. So that much uatural ability untiring energy and industry were needed by the manufacturers of that day. Such qualities George Whittle possessed in a marked degree, and it was therefore only natural that he shonld reap his reward and begin to grow prosperous.

His first wife was Miss Bailey, of Lengridge. On her death, ho married Mrs. Fleming, and lived at the old Parsonage, Longridge, having also a homo at Ellel.

In 1850 he commenced to build the "Stone Bridge Mill," the first steam-power weaving shed in Longridge, and so laid the foundation of the future prosperity of the place. From 1852- the year of the great Preston strike-to George Whittle's death in 1865, there was never any lack of work at this mill. Even during the long and 
troublous cotton-famine years, caused by the American war in 1861-62, no longer stoppage took place at Mr. Whittle's mill than a week or so, a fact almost without a parallel in Lancashire. Indeed, Blackburn manufacturer's and Manchester merchants used to point to Longridge as a place which might proudly boast in this respect. From that time to this the Longridge cotton cloth has kept the reputation won for it by George Whittle; and no place in Lancashire can boast of such a record of continuons work as this town, a fact which speaks volumes for master's and employés alike.

On 28th June, 1865, at the early age of 51, George Whittle passed away, amid the lamentations of the peoplo for miles around. An enormous crowd witnessed his funeral. An eye-witness of the scene says that Longridge on that day looked "black" from Tootal Height. All the mills and shops closed spontaneously for the whole day. Longridge was mourning for a strong and good man, for one who had tried to do his duty. Outwardly of a stern and unbending disposition, and a severe master, there beat beneath his somewhat commanding exterior a feeling and generous heart. As a former Longridge man with a natural gift of poetry said, at a concert in the village, at the conclusion of some verses in which references were made to several local gentlemen,

"He never forgot the poor,"

a sentiment which brought down "the house." At his death he left a wife and eight children. Above the family vault in the Longridge churchyard, in which rest the remains of himself, his two wives, and son George, there was erected a handsome granite obelisk.

But the true memorial of George Whittle are the comfortable homes of the cotton operatives of Longridge.

The Hon. F. A. Stanley, M.P., now Lord Stanley, and GovernorGeneral of Canada, made a very graceful allusion to the late George Whittle, in a speech at the dinner of the 3rd Longridge Agricultural Show, held August 10th, 1868.

"He had no doubt," said the right honourable gentleman, "but it wonld be in the recollection of all that Longridge was one of the localities which at the time that dire calamity overspread the country, known as the Cotton Famine, to the last held out in a great measure 
against applying for help elsewhere. It was one of those places in which the inhabitants, as it were, setting their shonlders to the wheel, Trere enabled by their own unaided exertions to carry this district on during that period. Nor would he do justice in referring to that cincumstance did he not make a further remark, and though it related to one who had in the meantime passed away from amongst them, yet, for the good deeds which he had been able to perform, it would be indeed a mark of ignorance on his part did he not advert more in detail to the bountiful manner in which one of those gentlemen, engaged in commercial pursuits, acted-he referred to the late $\mathrm{Mr}$. Whittle. He was enabled to do good in a great measure, which he (Mr. Stanley), thought characterized true benerolence."

Such a tribute from such a man paid to George Whittle, a political orponent of $\mathrm{Mr}$. Stanley, was creditable alike to both gentlemen.

\section{William MLarsden.}

Mr. William Marsden at the time of his death in 1882, was the oldest inhabitant in Longridge, indeed he was often called "the Father of Longridge." He came to Longridge about 1832, from Blackburn, as what was then called a "fester" loom reaver, for Horrocks, Jacson and Co., Preston, and entered into partnership with Mr. Tiayhurst, and built the Crumpax Mill in 1851. He was a kind and just employer of labour. Mr. Marsden was a man of strong political proclivities, being a "true blne" Conservative. One instance of his zeal for his party may be mentioned, as it was characteristic of the man. During the election of 1868 , it was found impossible to get a room sufficiently large for the meeting in support of the Hon. F. A. Stanley and Col. Wilson Patten (now Lord Winmarleigh), so Mr. Marsden emptied a spinning shed which he had at that time, so as to get the requisite accommodation. He was also a stannch Churchman ; and took a warm, if not very active, part in all matters pertaining to the welfare of the town in which he had lived for 50 years. He was twice married, and left three sons-Mr. J. N. Marsden, of Preston; the Rev. W. Marsten, M.A., Vicar of St. Chrysostom's, Manchester; and the Rev. Thomas Marslen, B.A., Rector of Chigwell.

1"One who puts cut." 
He died in July, 1882, aged 82, and was inter'ed in the Parish Churchyard, Longridge. Along with George Whittle, Mr. Marsden deserves to be remembered as one of the pioneers of the cotton trade in Longridge.

\section{Robert Surth.}

NIr. Robert Smith, J.P., of Dilworth House, Longridge, was born in 1828 , and is therefore 60 years of age. His father was a manufacturer and married George Whittle's sister, so that the subject of the present sketch is the nephew of the late George Whittle. Mr'. Smith was born at Withnell, near Chorley, but lived in Blackburn until the death of his mother, in 1847, when he came to learn the cotton business with his uncle at Longridge. In 1855, he started business on his own account as a hand-loom manufacturer, and soon acquired a good reputation for his steally business habits. In 1862 he built Victoria Miill, which then held 360 looms, but since then he has enlarged it and is also enlarging it at the present time. Mr. Smith developed very soon a speciality of his own, going in largely for fancy cloth for the home trade. His business has increased rapidly, and he has been very snccessful. But it must be omned that Mr. Smith has amply earned his good fortune, as ho has stuck exceedingly close to business, denying himself of almost all rest and recreation, except walking, of which exereise he is very fond.

$\mathrm{Mr}$. Smith is a strong Churchman, and his name figures prominently in the chapter on Ecclesiastical History. He has been Churchwarden many times, and, along with MIr. J. Pye Whittle, is in that office now. He has been the leading subscriber to the various movements for chureh and school extension. In 1885 he built at a cost of $£ 1,300$ the present Boys' School ; he subscribed $£ 1,000$ towards the cost, and is defraying the cost of the chancel of the new Church, which is nearly completed. Mr. Smith is Chairman of the local Conservative Party, and is a leading supporter of the Conservative cause in the Blackpool and Darwen Divisions, and has frequently entertained the member's of those Divisions. In 1886 he was made a Justice of the Peace for the County of Lancaster, and has assiduonsly attended to his duties as a magistrate; he is also a Visiting Justice of the I'hittinghan Asylum. On the formation of the Local Board he was elected Chairman, a 
position he has retained up to the present time. He is a leading landowner in the immediate district, and bears the reputation of being a good landlord.

Mr. Smith married Miss Mary Raby, daughter of the late Mr. J. Raby, of Landskill, a landed proprietor, and has six children living, viz., two daughters unmarried, and four sons.

William Simth.

Mr. Wm Smith, a partner in the firm of George Whittle \& Co., is a son of Mr. John Smith, of Mellor. He came to Longridge in 1840, where he became connected with his uncle, the late Mr. George Whittle. He is an exceptionally good business inan, energetic and clear-headed. He takes no part in public affrirs, being fond of shooting and fishing. He married Miss Edleston, and has two sons and a daughter.

\section{JAMES GREgory.}

Another Longridge worthy was James Gregory, who for 25 years taught the yonng and rising generation their reading, 'riting and 'rithmetic. Mr. Gregory was horn at Bolton, and after being two years at Cheltenham College, he had his first school at Whitby, where, however, he did not stay long, coming to Longridge in 1857. He morked hard at his congenial task, and soon acquired the reputation he always retained of being a model schoolmaster. He was patient and persevering, but maintained the strictest order and discipline by kinduess if possible, if not, otherwise. One well qualified to pass an opinion upon him, says: "Gregory was thoroughly imbued with the scholastic spirit, which made him a splendid master, but left him, like many of his class, pedagogic in everything else." "I have often," continued my informant, "gone up to R. H. Lightfoot's for the afternoon when Gregory was there. Soon we got on to politics, or some social topics, and so maddened have I been by the ipse dixit style of Gregory in arguing his point, that I have come away without staying tea as intended." What Gregory did for Longridge it is hard to overestimate. You can tell his pupils at a glance, and we fear very much that, since his death, the youth of Longridge have been sadly in want of his discipline and firmness. For several years I was a teacher under Gregory at the Sunday School, and always admired tho way in 
which he managed both teachers and scholars. One of his most intimate friends was R. H. Lightfoot, to whom I shall presently refer. In 1882 his health began to visibly fail, and after a lingering illness he quietly died on Aug. 16th, 1884, aged 49. The scene at the grare side was a sad, yet impressive one. The coffin was covered with wreaths; a large number of people were assembled, including over 300 day scholars. He left a widow to mourn his loss, while almost everyone in Longridge felt they had just seen the grave closed over one of the truest men they had known.

\section{R. H. LightFoot.}

On May 10th, 1881, passed array one of the gentlest men it has been my lot to know. Richard Henry Lightfoot did, in a quiet may, a great deal of hard and lasting work. By no means a strong man, for years he conducted a children's service in the old Boys' School. He was Secretary to the Day and Sunday Schools, filled the post of Churchwarden, visited the sick and poor, and led a life that was almost pathetic in its quiet and looly calm. He was for nearly 30 years the faithful and trusted confidential clerk of Mr. Robert Smith, (whose cousin he was), and from him I have learnt many a lesson which will not soon be forgotten. He was a great friend of James Gregory. After a long and very painful illness he died, aged 54. Alas!

$$
\begin{aligned}
& \text { The stars of those two gentle eyes } \\
& \text { Will shine no more ou earth. }
\end{aligned}
$$

He left a widow and family, who have keenly felt their sore need of him.

\section{J AMES DILWORTH.}

James Dilworth hailed from Chipping, where he was a hand-loom "putter-ont." He purchased Gleadale at the time it was a thatched cottage. He used to go by the stage coach to Manchester to attend the markets. On his return, it was his custom to have a meeting of the cuttagers in a room over the coach-house, called the "Chapel" to this day, and there delivered the sermon he had heard in Manchester. He lial a warehouse in Water Street, Preston, now belouging to Mrr. Walter Bibby, J.P. He effected a great change in the condition of the roads in the vicinity of lis "compact estate." He built one of the best huuses in Ribblesdale Plice, Preston, now owned and occupied by 
Niss Horrocks. His warehouse in Pall Mall, Manchester, is now owned by one of the most suceessful and world-renowned yarn agencies (James Dilworth and Sons,) in Cottonopolis.

The Misses Dilworth, we may add, have not forgotten Longridge, as they give an annual subscription to the Independent Chapel at Knowle Green. Mr. Dilworth-Harrison, the grandson of the late James Dilmorth, is the owner at present of Gleadale.

RoBert Ascroft.

Mr. Robert Ascroft was for many year's resident at Longridge. He was well known and highly respected in the district, owing to the interest he took in the welfare of the towu. From 1852 until 1875 ho held the post of Town Clerk of Preston, discharging his duties in a most able and efficient manner. He took a great iuterest in educational matters, in which good work he has been followed by his son, Mr. William Ascroft, of Preston. In politics, Mr. Aseroft was a strong and active Liboral; while he was a Churchman in religion. He died at Gleadale, Longridge, on November $14 \mathrm{th}, 1876$, aged 71 , and his remains are buried in the ohurehyard at Penwortham.

H. B. Jores.

Mr. H. B. Jones was Secretary of the Longrilge Railway for some years. He was an easy-going man, as the following instance shows: -The engine driver had instructions always to whistle hard when coming through the Stone Bridge Tunnel at Longridge, in order to waken this somnolent official; and often enough the train had to come to a standstill, owing to the Secretary being in bed. He took great interest in the religious welfare of the parish, so much so that whou the late Mr. R. Aseroft inquired the rent of Gleadale, MIr. Jones's residenee, he was told that the present tenant had the rent redueed becanso he looked after the welfare of the souls of the people. The landlord wanted to know if Mr. Ascroft would do the same; to which inquiry the latter rellied, "He had two daughters who might do so."

Dr. Eceles, Senior.

Dr. Eceles, the father of the present doctor, was a well-known man in Longridge society 40 and 50 years ago. Later in life he married, for his second wife, Mrs. Mc.Coskery, the noted landlady of the Wheat Sheaf Iun. 
As a medical practitioner, the late Dr. Eccles was held in deservedly high esteem by all the country side.

\section{Harry Eccles.}

One of his sons, Mr. Harry Eccles, was a very witty character; and one rather good tale of his, which I have heard my father often relate, may be repeated here. "One morning as the train was going to Preston, the engine left the line, just below the Stone Bridge Tunnel, and, of course, came to a sudden staudstill. At once Harry put his head out of the window, and shouted to the guard, 'I say, Jim, this is a queer place to land passengers at,' a remark which was received with uproarious laughter."

Another good story was told by Mr. H. Eccles at a dinner of the Longridge Agricultural Society. Replying to the toast of the "Town and Trade of Longridge," he concluded a humorous speech by saying: "If Longridge had another pump it would be a seaport!"

\section{Dr. Eduund Eccles.}

The present genial doctor, the late doctor's third son, is known for miles around as a clear-headed, clever, and experienced physician, and deservedly enjoys a large practice. $\mathrm{H}_{e}$ has lived a quiet, unostentatious life, being a great friend to the poor, by whom "Edmund" is loved and respected. He has endeavoured to improve the sanitary condition of Longridge by his recommendation of the dry-earth system. He has lived a hard life, being exposed to all weather, and taking very fow holidays. He is as good a sample of the better class of the old school of doctors as can be met with; bit lie does not forget to keep up with all the latest improvements in medical and surgical science.

\section{William Prestwich.}

William Prestwich, the late Sexton and Clerk of Longridge Parish Cluurch, was another noted man in Longridge. He came from Cliowbent in 1832, and established himself as a nail maker (Longridge being woted at that time for nailmaking). As a steady young man, he was appointed Clerk and Sexton iu Mr. Pigot's time, in 1844, and held these offices until his death, in 1885 . Forty years ago, when he was about 38 years of age, he became one of the most notorious 
drunkards in the district, and many tales of his ronderful drinking feats are current to this date. His fall from sobriety was due to the drinking customs then and still prevalent (though in a less degree) at funerals. And as he himself once pathetically remarked, "It is not my young life, ner my old life, hut my middle life that I have to regret." For, in 1863 , he became quite a reformed character, and ever after was one of the most enthusiastic teetotal advocates in Lancashire, making in his speeches effective use of his orn experiences as a drinker. In some things he was rather eccentric, and of late years, being very deaf, and slightly absent-minded, provoked some amusement in Church. But he was a good man, and mucl respected by all who knew him. He died at the ripe old age of 76 , having thus acted as Clerk and Sexton for over 41 years. During his term of office he assisted at and in most cases dug the graves for 1,755 funerals. He was very faithful in the discharge of his duties. $\mathrm{H}_{e}$ was also Bellman, heing presented with a new bell by the inhabitants on his appointment in 1848.

A good story of the late $\mathrm{Wm}$. Prestwich is worth relating. One day a lady and gentleman went to look at the Church, and were just going into the belfry when they discovered the venerable Clerk, attired in a strange and ronderful manner, violently beckoning them not to approach. Disregarding his gesticulations, the visitors drew near, and found the clerk busy dusting the belfry. In order to save his clothes, he had put on the Vicar's surplice and fastened some cleau towels round his legs, with a skull cap on his head. He naturally looked very comical. After enjoying a good laugh the amused visitors retired, leaving the careful sexton to disrobe at his leisure.

\section{Henry Hoole.}

Mr. Henry Hoole, who was schoolmaster of the National School before Gregory, was, when the author wrote this sketcl, looking remarkably well. I am much indebted to Mr. Hoole for the reminiscences he has given me of Longridge life. I am told that Henry Hoole was a good schoelmaster, and much liked by the "aristocracy" of Longridge, which comprised at that time such men as George Whittle, Dr. Eccles, Wm. Marsden, Shuttleworth, Mr. Tobin, T. Fleming, Fletcher, Spencer, \&e. 
Mr. Hoole is nearly 80 years old, and bears his old age extremely well.

\section{R. B. Dixoy.}

Mr. Dixon had a Tannery in what is still called Tan-Yard Lane. $\mathrm{He}$ was most zealons in promoting the interests of the Church. $\mathrm{He}$ was a great friend of Mr. Pigot, who was Vicar of Longridge from $1843-47$.

\section{JANES TULLIS.}

Mrr. James Tullis, a member of the firn of Cooper \& Tullis, has been the main stay and support of the Independent Church of Longridge since its establishment. His good deeds are not confined to helping on one denomination only. He is always ready (as is his wife), to give a helping hand to any gool cause, or any deserving, and sometimes undeserving, people in distress. He gives like

One who gave by stealth, And blushed to find it known.

Mr. Trullis came to Preston in 1834, having beeu born at Cupar, Fife, in 1824. His firm soon became known as a first-class one in the stone and building trade. Mention has been made of several of the leading works they have successfully carried out. Mr. Tullis lives a quiet, retired life, but is always willing to do what he can to promote the prosperity of Longridge.

\section{David Irvin, J.P.}

The subject of this sketch has filled an important part in public affairs at Longridge during the last 30 and 40 years. One of the original supporters of the introduction of gas into the town, Mr. Irvin has been Chairman of the Company for some time. He was also the only resident magistrate in tho district for a considerable period, and, of course, had a great deal of work to do. Mr. Invin has taken a leading part in politics, and as the head of a weak Liberal party, among bitter and powerful opponents, has had to bear a lot of hard words and nasty deeds. But he is almost as active and checrful now as ever, although fast nearing the age of fourscore. In religion Mr. Irvin is a Churchman. He lives just outside the Longridge boundary, in Hothersall. He is a member of the firm of Irvin \& Seller's, Preston. 
Very brief notices can only be given of the following local celebrities :-

Davio Nuttali.

Mr. Nuttall owned the first hand-loom Spinning Mill in Longridge. He built Dilworth House, in which he also lived for some years, and was Churchwarden several times. He was an energetic man in all things.

Grace Watson.

A well-known character was Grace Watson, who for many years used to cart stones to Preston from Messrs. Cooper and Tullis' quarry. She wore a top coat, thick boots, and looked outwardly very like a man. She lived at Nook Fold, and there are in existence a couple of very primitive water-colour sketches of the Amazon, her mother, and her horse. She died about 10 years ago.

George Baxiss.

Mr. Banks comes of a very old Longridge family. His father was for many years landlord of the Black Bull Inn. George Banks has takeu an active part in local affairs, and is well known as an inventive genius (thus taking after his father, see p. 42), being particularly anxious to discover a flying machine. $\mathrm{He}$ is engaged in the stone trade.

\section{JoHN Banks.}

Mr. John Banks, the brother of George, has for a long time acted as Guardian of the Poor for Dilworth. He is an extremely keen and active man for his years, and devotes much attention to his duties as a visiting guardian of the Ribchester Workhouse. He is well known as a clever auctioneer.

\section{Benjamin Waluistey.}

Mr. Alderman B. Walmsley, ex-Mayor of Preston, was for a few years (1862-67) secretary to the Longridge Railway. He was assiduous in attending to his duties, and developed the traffic largely during his tenure of office. He was mainly instrumental in promoting the Agricultural Show at Longridge. As secretary of the Church Extension Committee from 1873-75, Mr. Walmsley worked very energetically. He has acted as churchwarlen, and iu various other ways displayed great anxiety to help on the place. He took a great interest in Long- 
ridge politics, even after he had gone to reside at Preston-on the Conservative side, of course. His fondness for cricket is well known, and it was only last season that he played a very creditable innings for the Longridge Cricket Club. $\mathrm{H}_{\theta}$ is very popular in Longridge, and, we think, deservedly so. Mr. Walmsley is, we should say, 55 to 60 years old, but is as active as ever he was.

Local Authors.

Longridge authors are few indeed. About 20 or 30 years ago the late Mr. John Halsall contributed several readable articles to the Preston papers, from some of which $I$ have quoted; but $I$ have in vain tried to find out anything more about him except that his father was the first relieving officer for Alston Poor Law district.

Mr. J. Catlow, formerly resident in Longridge, composed on various occasions ballads and songs, none of which have, however, been printed, so far as I know.

Mr. Cottan.

Mr. Cottam, of Hurst Green, whose name figures frequently in Peter Walkden's Diary, seems to have been a noted character in his day. He was schoolmaster at Hurst Green, and also acted in the capacity of clerk at auction sales. But he is perhaps better known as a poet. "The Stonyhurst Buck Hunt," a couple of verses of which are giren below, is the best known of his poems. He also wrote "Hie aray to Rossall Point,": "The Burnley Haymakers," and a song called "The Fivo-barred Gate." His account of Stonyhurst Buck Hunt, detailing the particulars of the chase of that day, which was honoured with the presence of the Duke of Norfolk, his noble brothers, and his kinsman, John Talbot, accompanied by Mr. Waters, Mr. Harris, and Mr. Penketh, all of whom were gentlemen fond of the turf, and who stood at nought in taking a leap when in view "Halloo!" is very interesting :-

To Whalley Moor therefore he ran,

To Clitheroe and Waddington ;

Yet visits Mitton by the way,

Although he had no time to stay.]

1Mr. Harland says: -"We have souglut in vain for these two songs. Are

they irrecoverably lost?" 
To Stony Moor this buck then fled, Where we did think him almost dead; To Storth and Foulseales then he hied, And then to pleasant Hodder side; But had not Famons lahour'd sore, We'd hunted all the forest o'er.

I also give a verse from the Burntey Haymakers (sung by Robin O'Green, Fixit, 1790):

Help goddess muse to sing of revelations, Fanatic dreams or news from the stars,

Knowledge refined, mysterious speculations, Secondary causes of peace or wars. See how the plotting heavens In a summer's even,

Together make weather at their own dispose, And to the Sons of art, Their secrets do impart

And all their consultations most willingly disclose,

"Robin O'Green's portrait," says Mr. WV. Waddington, of Burnley, to whom I am indebted for much interesting information, "hung for many years at Towneley Hall, it was an engraving, resembling some of the figures in Tim Bobbin's Human Pussions Delineated. There is a tradition that this picture was once exhibited in the House of Commons to shew what Lancashire men were like."

Rev. Charles Boardian, D.D.

Dr. Boardman, to whom further reference is made in Chapter II., is on $\theta$ of the solitary authors we have in Longridge. He has contributed articles and reviews to various periodicals; has been librarian at Stonyhurst and several other colleges, and has compiled a catalogue of the older MSS., and also of the Black Letter books in the Stonyhurst library, the latter of which has been privately printed. 
CHAPTER Y.-TOPOGRAPHY AND AGRICULTURE.

Romantic scenery-R. Parkinson-Canon Parkinson's "Prospect"-Jeffrey Hill "Scarsdale"-Baines-Tootal Height-J. Weld, on Tenlaes-E. Kirk-J. McKay-Legends : Ned of the Fell-Ghosts-Landowners-Court Leet-Agricultural Produce-Acreage-Agricultural Statistics-Farming in 1700-Prices, 1720-60-Peter Walkden-Farming in 1790--Leaves from a Farmer's Diary, 1816 $1839-$ Charities : R. Houghton's-T. Honghton's-Jenkinson's-Gregson's and Eccles's--Berry's-Roades's-Townley's-Population.

THE scenery around Longridge is of the most beautiful and varied kind; while $I$ do not think any more extensive viow can be obtained than that from some of the heights in the neighbourhood.

Many writers have given glowing descriptions of the views about here, but perhaps one of the best is given by Mr. Richard Parkinson as a contribution to the "Old Church Clock." I venture to extract it for my readers' benefit:- "If you stand on the ruins of Clitheroe Castle (10 miles from Longridge) and look to the north-west, a noble expanse of country stretches out before you. At your feet rolls the well-knowu and romantic Ribble; further on its grand tributary, the Hodder, pops out in places, glistening in the sun, gliding between the limestone hillocks or woody dales of Bowland or Browsholme. To the left the hoary tips of Mytton and Whalley crop out, and the long range of Longridge Fell stretches out towards Preston, shutting out the time-honoured valley in which nestle Stidd and Ribchester. In front, a vast view is commanded. To the north rises the precipitous barrier known as Bleasdale Fells, and at the easterly points of this we find the sweet little anglers' rest known as White Well. Abutting from the last named mountainous chain stands Parlick Pike, a hill some 1,500 feet high, aud on its summit ( 5 miles from Longridge) we will suppose ourselves standing. No spot in England that I have seen commands a finer view than this. Its top is almost flat, and is crowned by a stone edifice, ${ }^{2}$ the erection of which is traditionally alluded to as having been directed by some evil spirit. From this point spreads out like a map a country of which any dukedom might be proud-Chipping, Chaigley, and Bowland to the left, with the grey and timehonoured Clitheroe Castle. Beyond the rast ridge above Stonyhurst

${ }^{1}$ Long since disappeared. 
rises the dense smoke of Blackburn; in front, Goosnargh, Broughton, Alston, Whittingham, and the forest of smoke-emitting chimneys of Preston (too far away to coutaminate the purest of atmospheric breezes around you), and the widening ship-laden mouth of the Ribble dotting the estuary of the old Roman port. Beyond this, Liverpool, and far away again the tips of the Welsh mountains struggle with the clouds for identification. To the right, a long expanse of the coast, upon which you can distinctly recognise the principal buildings of Lytham, Blackpool, Southport aud Fleetwood. At your feet, among the innumerable homesteads, cosely lies one looking wuch like a bird's nest, a house encircled by a plantation, the blue smoke curling up in fantastical wreaths, giving an impression of rustic peace and comfort, in itself quite a picture, and a theme for contemplation when we kuow that this is 'Woodgate,' the birthplace of Canon Parkinson."

The author of the "Old Church Clock," in a poem called "The Prospect," gives a fine description of the varied and interesting scenery commanded from the summit of Parlick Pike :-

\section{A PRosPECT.}

With labouring step and panting breast

I climb'] you mountain's side,

Whose fountain-deck'l high towering crest

O'er looks the region wide ;

And o'er a scene of hill and vale

My' gladden'd eyes I threw,

Such as ne'er grac'd a poet's tale,

Nor pencil ever drew.

Far to the enst, where Hodder flows,

IVild Bowland's crags are seen,

Whose waring wood its shadow throws

Yon verdant knolls between;

There ance the roebuck bounded free, There rung the winded horn,

Where now but spreads the greenwood tree, The hazel and the thorn.

Northward a glowing scene expandsThe silver Lune is there;

And Morecambe, with its glittering sands, And ancient Lancaster.

While o'er the seene, of darksome blue,

The Cumbrian mountrins rise, 
Like giant clouds in shape and hue

They tuwer unto the skies.

The level plain is spread below, In one unbounded scene ;

Coru fields and meads, in various row, And every varying green;

The rich demesne, the chequer'd ground

Extends to ocean's brim,

That bounds the mighty prospect round, As with a golden rim.

Yon speck, so dark amid the plain,

Is Hoghton's ruin'd Tower ;

Deserted is the wide domain,

And silent ball and bower ;

Yet oft, of yore, wild mirth has play'd

Around the festive board,

Where knighthood on the loin was laid

By James's royal sword.

And there the gentle Ribble goes,

By varied hill and plain;

Than which no lovelier river flows

Down to the western main;

Its banks, as fair as banks of Thames, Are decked with castles hoar;

Once the ahode of men whose names

And memory are no more.

Yet mourn not, river ! other names

And other balls are thine,

And lovely are the towers and dames,

Around thy port that shine.

Fair are the groves, the meads, the vales,

Through which thy currents run,

And sweetly glance thy gliding sails

Beneath the western sun.

Bright is the scene; and over all

'The sun's last beams are shed,

Upon yon glittering roofs they fall,

And gild yon mountain's head;

A soft light o'er the forest fling,

Whose deepening shadows rise;

While, overhead, the skylarks sing

Their vespers in the skies.

${ }^{1}$ Now, as is well-known, Sir Charles

Tower. 
The "Prospect" attempted to be sketched in the preceding poem, is taken from Parlick Pike, a mountain which forms the south-western angle of that lofty range of hills which divide the counties of Lancaster and York. Owing to its remote distance from any large town or public road, it is a scene little known to the traveller, but not on that account the less worthy of admiration; for there are few views in England which can bear a comparison with it, at once for extent, variety, and sublimity. The chain of mountains itself is lofty and picturesque, here swelling into the towering summits of Pendle and Ingleborough, and there gradually subsiding into the undulating swells of Craven, and the billowy ridges of Longrilge and Whittle Hills. The Fylde country, between the mountains and the sea, is one of the richest in the kingdom; and the Ribble, a beantiful river, was once celebrated for the number of ancient families stationed on its banks, and still for the ruins of their knightly or manorial houses. Hoghton Tower, the old residence of the family to which it has given a name, is the baronial hall in which tradition reports James I. to have knighted the Sirloin, when he visited that part of the country with great state and magnificence. On the whole, the author has no fears that the scene which he has attempted to describe will be found to have derived its brightest hues from being that which he first gazed upon in infancy.Canon R. Parkingon.

An equally splendid view to that described by the Parkinsons can be obtained on a fine day from Jeffrey Hill, which is 1,016 feet above sea level.

Sir James Kay-Shuttleworth, in his very interesting work "Scarsdale," breaks out into eloquent language when he describes the scenery of this part of Lancashire.

Baines thus describes Longridge:-

Longridge Hill gives to this parish, at its northem extremity, a barren and sterile appearance, but cultivation has been carried by human industry to the summits of this elevated region. In the valley on the banks of the Ribble, the meadows and pastures are for the most part fertile, and the scenery in many situations beautifully picturesque. The country is well wooded, except on the hills, and there plantation work has not been wholly neglected. The farms are small, and many of them freehold; and though the parish has been deserted by the ancient gentry of the county, their place is occupied by a race of stalwart labourers and respectable yeomen.

Tootal (or Tootel) Height is often used as the name of the locality of Longridge. It is a striking and rather abrupt rising eminence, and presents a bold and striking appearance when viewed from the town of Longridge. It stands 598 feet above sea level. From its summit a very extensivo view is obtained, and it is a frequent resort for health and pleasure seekers. At its foot lies the pretty "Spade Mill" reservoir. Tootel Height doubtless was used for signalling purposes, and also for the Tenlaes. 
Mr. J. Weld, J.P., in the November number (1888) of the "Stonyhurst Magazine," makes the following interesting observations :-

After a time the Englishmen sent word to their women that when they saw fires lighted on the hills about they were to cut their new masters' (the Danes) throats as they lay asleep. Fires were lighted on Parlic, on Beacon Fell, on Longridge Fells, and on Pendle. Then the women did as they were bid, and murdered the sleeping Danes.

Tenlaes.-This was the name given to other fire celebrations, observed till quite recent times, ${ }^{1}$ on May 1st, Midsummer Day, and especially November 1st. They were originally feasts of the sun, and it is clear that sun or fire worship was at one time'much in vogue in the district. Parlic, originally Pyre-lich (as it is called in maps of the time of Henry VIII.) and Beacon Fell have evidently been great seats of its ceremonials. Numbers of stones still lie on their tops, which were brought there probably for cairns. - - Old men say that in their youth a ring of fire could be seen on All Saints night all rourd the horizon.

"It would appear," says Mr. E. Kirk, "from the following lines in the boat song, in The Lady of the Lake-

Blooming at Beltane, in winter to fade,

that the Scotch celebrated their fire worship about May. In the Nook, Teanla Neet was the last night in August. In the autumn of 1848, I saw what I was told was 'brunnin' teanla.' This, like many other of the very old customs, lingered longest among the Roman Catholics, and the explanation of it which the old folk gave was, that they (the Catholics) 'were leetin' th' souls o' their relations out o' Purgatory.'"

What the origin of the name Tootel is I do not know. The Tootels were a well-known family in the neighbourhood in the last century, and may have given their name to the hill. Mr. J. M'Kay, in his "Pendle Hill," recently published, inclines to the opinion that "Tootal" is of Celtic origin from Tith, and that it was sacred to the Celtic Teutates, who paid divine adoration to the stars by night and to the sun by day. The meaning of the word then, according to Mr. M'Kay, is "holy mound" or "Toot Hill," dedicated to the great Celtic god Taute or Mercury.

The following legends are connected with Longridge:-

"In the range of hills called 'Geoffry Hill' was a cavern, in which lived for years a freebooter named 'Ned of the Foll.' The legend respecting this robber is contained in a book now very scarce, but we believe a copy was in possession of the late Mr. Spencer, of Dilworth." 
"A woman in white, the spirit of one that was said to have been murdered, was to be seen at "Daniel Plot.'"1

"At Walton Fold was a demon who committed many strange vagaries until 'Iaid' by a priest, the Rev. Jas. Fisher."

"Hollins Hall (Holly Hall, vide Ordnance Map), a house and tannery on the base of Tootel Height. The writer remembers going forty years ago (1830) to Hollins Hall, a moderate sized farm house, to see the spirit's domicile."

There is some very good grazing land in Longridge, the value of the best being about $£ 3$ to $£ 4$ per acre per annum.

The chief landowners are:-Frederick Openshaw, Esq., J.P., Hothersall Hall, 1,216 acres; John Mercer, Esq., J.P., Alston Hall, 482 acres; the late Thos. Whittaker, Esq., J.P., Moon's Mill, 318 acres; Mr. John Smith, Duxon Dean, 161 acres; Colonel Bickerstaffe, London, 114 acres; Robert Smitl, Esq., J.P., Dilworth House, 110 acres. Wm. Cross, Esq., of Newcastle-upon-Tyne, nephew of Lord Cross, is Lord of the Manor, and annually holds his Court Leet at Longridge.

This Court Leet or Baron empannels a jury, and issues its decrees in due form. I have one of these decrees in my possession. Its perusal may interest my readers :-

The Maxor of Alston, with tTs Memberz in the County of Lancaster.

At the Court Baron of William Assheton Cross, Esq., Lord of the Manor aforesaid, holden at the House of Margaret Winder, innkeeper, within the said Manor, on Tuesday, the 11th day of June iust., the Jury were of opinion and found and ordered that seeing that you had rendered the road to Mr. ___'s property im. pasable by reason of your having removed by quarrying the stone forming part of the road, you should construct a Bridge over your quarry on to the property of Mr. -, to enable that gentleman to get on to his property with carts and carriages.

As Steward, I have to request that the above finding and order of the Court may be complied with at once.

To Mr.

JOS. B. DICKSON. 12th June, I872.

Longridge.

Need I say the abore order was not complied with.

¿Now called Daniel Plat. 
Milk, butter, and beef are the leading agricultural products in the district, and the farmers seem able to make a fair living, although they justly complain of the present high rents. The land lies well on the slopes of the "Long Ridge," on which the town is built. The total acreage of Longridge is 3,215 acres; Alston, 1,989 acres; Dilworth, 1,226 acres. The following statistics are taken from the returns made to Government in 1886 :-

Agricultural Statistics.

Number of Statute or Imperial Acres under-*

\begin{tabular}{|c|c|c|c|c|c|}
\hline \multirow{2}{*}{ Township. } & \multirow{2}{*}{$\begin{array}{l}\text { No. of } \\
\text { Returns } \\
\text { obtained } \\
\text { from } \\
\text { occupiers } \\
\text { of land. }\end{array}$} & \multirow{2}{*}{$\frac{\text { Corn Crops. }}{\text { Oats. }}$} & \multicolumn{2}{|c|}{ Green Crops. } & \multirow{2}{*}{ Clover, \&c: } \\
\hline & & & Potatoes. & $\begin{array}{c}\text { Other } \\
\text { Green Crops. }\end{array}$ & \\
\hline $\begin{array}{l}\text { Dilworth ......... } \\
\text { Alston ........... }\end{array}$ & $\begin{array}{l}42 \\
60\end{array}$ & $\ddot{3}$ & $\begin{array}{l}\frac{1}{4} \\
\frac{3}{4}\end{array}$ & $\begin{array}{l}\frac{1}{2} \\
1\end{array}$ & $\begin{array}{c}\frac{1}{2} \\
\cdots\end{array}$ \\
\hline Township. & $\begin{array}{l}\text { Permanent } \\
\text { Grass ts be cut } \\
\text { for hay } \\
\text { this year. }\end{array}$ & $\begin{array}{c}\text { Permanent } \\
\text { Grass land } \\
\text { not to be cut } \\
\text { for hay } \\
\text { this year. }\end{array}$ & Orchards. & $\begin{array}{c}\text { No. of } \\
\text { Built Silos. }\end{array}$ & $\begin{array}{l}\text { No. of } \\
\text { Stacked } \\
\text { Silos. }\end{array}$ \\
\hline $\begin{array}{l}\text { Dilworth ......... } \\
\text { Alston ........... }\end{array}$ & $\begin{array}{l}296 \\
562 \frac{3}{4}\end{array}$ & $\begin{array}{r}730 \frac{1}{2} \\
1304 \frac{9}{4}\end{array}$ & $\begin{array}{l}1 \\
3 \frac{1}{2}\end{array}$ & $\ddot{2}$ & $\begin{array}{l}3 \\
3\end{array}$ \\
\hline
\end{tabular}

* Quantities less than $\frac{1}{4}$-acre not included.

Live Stock on 4til June, 1886.

\begin{tabular}{|c|c|c|c|c|c|c|c|}
\hline \multirow{3}{*}{ Township. } & \multirow{3}{*}{$\begin{array}{c}\text { No. of } \\
\text { Returns } \\
\text { obtained } \\
\text { from } \\
\text { occupiers } \\
\text { of land. }\end{array}$} & \multicolumn{3}{|c|}{ Numser of Horses. } & \multirow{3}{*}{$\begin{array}{c}\text { Number of } \\
\text { Cows and } \\
\text { Heifers of all } \\
\text { Ages, in Nilk } \\
\text { or in Calf. }\end{array}$} & \multirow{2}{*}{\multicolumn{2}{|c|}{$\begin{array}{l}\text { NUMBER OF CATTLE } \\
\text { OTHRR THAN THOSB IN } \\
\text { MLL E OR CALP. }\end{array}$}} \\
\hline & & & & & & & \\
\hline & & $\begin{array}{l}\text { Agricul- } \\
\text { tural } \\
\text { Solely. }\end{array}$ & $\begin{array}{l}\text { Un- } \\
\text { broken } \\
\text { Iforses. }\end{array}$ & $\begin{array}{l}\text { Breeding } \\
\text { IIorses } \\
\text { Solely. }\end{array}$ & & $\begin{array}{c}2 \text { years } \\
\text { old and } \\
\text { under. }\end{array}$ & $\begin{array}{c}\text { Under } \\
2 \text { years. }\end{array}$ \\
\hline Dilworth.. & 42 & 17 & 6 & $\ldots$ & 240 & 76 & 151 \\
\hline Alston.... & 60 & 29 & 22 & ... & 403 & 126 & 343 \\
\hline
\end{tabular}




\begin{tabular}{|c|c|c|c|c|c|c|c|}
\hline \multirow{2}{*}{ Township. } & \multirow{2}{*}{$\begin{array}{l}\text { Number of } \\
\text { sheep of } \\
\text { all kinds } \\
2 \text { year old } \\
\text { and above. }\end{array}$} & \multirow{2}{*}{$\begin{array}{l}\text { Number } \\
\text { of Lambs } \\
\text { under } \\
\text { one } \\
\text { year. }\end{array}$} & \multirow{2}{*}{$\begin{array}{c}\text { Number } \\
\text { of Pigs } \\
\text { of all } \\
\text { kinds } \\
\text { and ages. }\end{array}$} & \multicolumn{4}{|c|}{ NUMBer of POULtr..* } \\
\hline & & & & Turkeys. & Geese, & Ducks. & Fowls. \\
\hline Dilworth & 247 & 165 & 28 & 2 & 16 & 84 & 1084 \\
\hline Alston ............ & 557 & 523 & 60 & $\ldots$ & 41 & 41 & 1304 \\
\hline
\end{tabular}

* The Returns are hardly accurate, the returns not having beeu fully made.

Leland, writing temp Hen. VIII., says: "The Grouud between Morl and Preston enclosed for pasture and corn, but were the raste Mores and Mosses be, wherby as in Hegges Rowes by side Grorettes there is reasonable woodde for Buildding, and sum for Fier, yet al the people ther for the most part bume Turfes. Likewise is the soil betwixt Preston and Garstan, but alway the most part of the Inclosures be for Pasturages. Whete is not veri communely sorrid in thes Partes aforesaid."

The following extract is interesting :

Lancasbire, chiefly in these parts, is most remarkable for breeding cattle of a size more than ordinarily large, particularly about Barnsley and Maudsley, from which places I have known eattle sold at extraorlinary rates, and heifers sometines amounting to fifteen or twenty pounds. The ground they feed upou is usually upon an ascent, and the grass shorter that in lower grounds. The usual method is to buy calves in those parts when they are about one year old, then, by removing to a more fruitful pasture, they arrive to a larger pitch than usual. - "Leigh's Natural 14istory," pub. in 1700.

In Walkden's days (1720-60), as he shows, the price of agricultural produce was as follows :

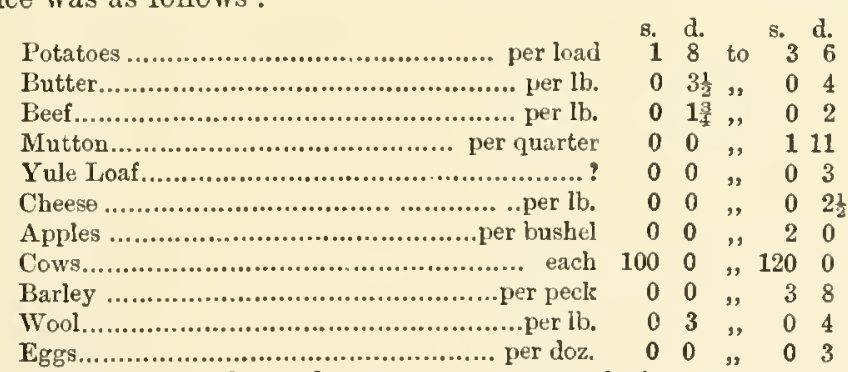

On the other hand, coal was $5 \mathrm{~s}$. a ewt., of six scores to the cwt. Wages were lor. A thatcher got 10d. a day, finding his owu victuals. 
A thrasher got $4 \mathrm{~d}$. a day. The value of women's lakeur was even less than it is now. Walkden's wife asked $12 \mathrm{~d}$. a week, but ultimately agreed to take $9 \mathrm{~d}$. a week! Horse labour was $6 \mathrm{~d}$. a day.

The honest and God-fearing parson was no teetotaler. He enjoyed a glass of ale, which he found refreshing. The diary abounds in notes like the following:- "After service I paid $2 \mathrm{~d}$. for ale, a penny dinner, a penny tobacco, and a penny for my mare."

In a country like this it is very ill judged to have a farm contain a whole country. I would divide them into small parcels anywhere from $£ 5$ to $£ 20$ per annum. Milk and butter are the chief articles wanted there, which are got without losing much sweat, and too often suits the constitution, or at least the inclination of Manufacturers. On small farms the land is better managed, the rent better paid, and I'm confident the landlord's bag will weigh heavier at the rent day. Some will say there are more buildings to maintain, and it is creditable for a gentleman to say what a large farm he has. But I think now a days the greatest credit lies in making the most money of an estate. "Transcript of a Valuation Book, circa 1799," on the fly leaf of which is written in pencil, "By Mr. Bootle's Steward."1 (1871 edit.)

From a series of old farming diaries (kindly lent me by Mrs. Stoddert, of Wilpshire) kept by the late Mr. R. Dunderdale, of Wheatley, Thornley, I have been enabled to gather some interesting notes about the state of agriculture in this district, during the early part of the nineteenth century.

"In 1816, Cattle Fairs at Longridge, May 13, Nov. 5: horned cattle and horses.

"Begun shearing on 7th Oct., ended on the 26th Oct. Very late barvest and abundanco of rain this year. 2 acres of corn to clear at Daub Hall, Nov. 12th. $W_{\theta}$ had done houseing Nov. 14th. Tro times a thickness of snow on the Hatlocks. Meall $£ 3$ 10s. Od. per load this month (Dec.). Flower (flour) unsound in general. Old wheat 4 d. per windle. Riots at London.

"1820. Feb. 26. Begun ploughing in peagraves. Begun haytime this year on 5th July. Done 22nd inst. Begun shearing 1st Sept., done 16th inst. Milk cows laid in on 21st Octr. List of Fairs : Longridge, Mar. 16, April 16, Nov. 5.

"1822.-Young beasts laid out 27th April. Milk cows laid out 16th May; horses on 23rd May. Begun hay-time July 6th, done Aug. 5th. A deal of rain this hay-time.

"Crostons "History of Samlesbury." 
"New house built this year at Oder [Hodder] Inn, intended for Publick House.

"1838.-Begun haytime on 21st July, done on 27th Aug. Very bad hay-time this year; several floods.

"1839.-Done hay-time 13th Aug., being a month with it, but good hay gotten in general.

"1840.-Jos. Corbridge and family set of from Thornley on 4th Sept., to go to America, the place appointed for fanaticks and liars.

"1865.-Died on 18th Nor., David Nutter, Esq., of Preston, formerly of Longridge, aged 90 years.

"Died on 24th June, George Whittle, Cotton Mauufacturer, Longridge, aged 51 years. Buried at Longridge ou 5th Jnly."

The Longridge Charities are neither numerous nor important, but some account of their origin may be interesting:-

Township of Alstor.

RICHARD HOUGHTON'S CHARITY.

The particulars of this charity, under which the poor of the township of Alston are entitled to one moiety of the rent of a close, called Wood Crook, in Whittingham, will be found in our 11 th report, p. 327. Since that account was drawn up, the rent has been reduced from $£ 10$ to $£ 5$, the close having been let at this rent, by a verbal agreement, for a term of seven years from 2nd February, 1825, to Richard Dixon, the tenant, who had previously held it at $£ 10$. The cause assigned for this great reduction is that the land was very much impoverished by having been too frequently ploughed. The trustees found that they could not let the land to advantage to any other person, as there was no road to it except through other grounds belonging to Richard Dixon, and they therefore let the close to him again upon an engagement on his part that he would lay it down in grass. It is stated that it will be several years before the land can be brought into a good state of cultivation. The Rev. Robert Parkinson and William Bnck, two of the trustees residing in Alston, distribute one moiety of the rents on St. Thomas's Day amongst the poor of this township, generally in sums varying from 6 d. to $2 \mathrm{~s} .6 \mathrm{~d}$., and of late years a regular account has been kept. Previously to 1819,10 s. out of the sum of $£ 110$ s., which was the 
share then payable to this tornship, was distributed to the poor of the township of Dilworth, but this practice was discontinued, as it was found not to be consistent with the directions of the donor.

THOMAS hOUQHTON'S CHARITY.

The particulars of Thomas Houghton's charity, under which the poor of this township, with the poor of the township of Elston, in the parish of Preston, are entitled to one-fourth of the rents of a farm, situate in Woodplumpton and Broughton, will be found in our 11th report, p. 331. Of this fourth part of the rent, one-third is given to the poor of Elston, and the remainder to the poor of Alston. This division is very ancient, and the poor in this township are much more numerous than those in Elston.

The sum of $£ 10$ is transmitted by Richard Walmsley, one of the trustees, to one of the principal inhabitants in this township, and it is distributed on St. Thomas's Day, by the minister, township officers, and principal inhabitauts, amongst all the poor in this township, together with the sum of $8 \mathrm{~s}$., being the yearly produce of Jenkinson's charity, hereafter mentioned, in sums varying from $1 \mathrm{~s}$. $6 \mathrm{~d}$. to $7 \mathrm{~s}$.

The present value of Richard Houghton's charity is $£ 14$ 7s. 6d.; out of which $£ 312 \mathrm{~s}$. 6 d. each is paid to the Vicar of Preston and the Vicar of Samlesbury. The balance is distributed yearly in sums of 1s. 6r. to 4s. to the poor people of Alston.

Thonas Houghton's charity amounted last year to $£ 10$.

\section{JENKINSON'S CHARITY.}

There is an entry in a book belonging to this township, dated in 1777 , and signed by several of the inhabitants, stating that, as $£ 10$, called Jenkinson's money, left to be divided amongst poor housekeepers at Christmas, had been expended for the town's use, it was agreed that the overseer should distribute every year to poor housekeepers $8 \mathrm{~s}$. yearly from the town for ever, or the money made up and put out again.

The annual sum of $8 \mathrm{~s}$. is paid out of the poor's rates by the overseer, and distributed with Thomas Houghton's charity, as before-stated. 
CHARITIES OF GREGSON AND ECCLES.

Thomas Gregson, by will bearing date 28th December, 1742, charged a messuage and tenement in Alston, containing by estimation $27 \frac{1}{3}$ acres, which he gave to Thom 2 Eccles, his nephew and his heir, and a leasehold tenement, held under Sir Henry Hoghton, with the payment, amongst other legacies, of $£ 10$ to his exccutors, which he directed to be put out at interest, and that the interest should be applied yearly by them and the survivor, and their heirs, executors, and administrators, for ever, toward clothing such of the poor of Alston as his executors should think proper.

The said Thomas Eccles, by will bearing date 7th Narch, 1777, gave to his brother, Edmund Eccles, and his eldest son, Seth Eccles, and the survivor, and the heirs of such survivor, his freehold estate, then in his possession, containing 26 acres, after the decease of his wife, to the use of his son Thomas, and his heirs, charged upon the said Thomas's coming of age with the payment of $£ 10$, the interest of which he directed should be applied for ever towards clothing such of the poor of Alston as his executors and the survivor of them shall think proper. It is supposed that this was only intended as a confirmation of the former gift of $£ 10$.

Thomas Eccles, the devisee under the last-mentioned will, was a cotton spinner, and failed in business, and this estate was sold by his assignees to Seth Eccles, the present proprietor. It does not appear that the $£ 10$ was ever paid, or that auything has ever been given to the poor in respect thereof, and as both wills bear date subsequently to the passing of the statute of 9 Geo. II., c. 36 , the gift seems to be irrecoverable.

BERRY'S CHARITY.

The following account of the gift of James Berry was obtained from Thomas Eccles, now living at Alston :- ${ }^{1}$

"James Berry, of Alston, in his life-time, gave to Seth Eccles, of Alston, tanner, the sum of $£ 200$, then in the Preston bank, in or about the year 1803, with this verbal injunction, 'that he should distribute the yearly interest amongst such poor and distressed people as he, in his discretion, should consider as objects of charity.'

${ }^{1}$ Now old, of course. 
The sum of $£ 200$ aboveme-ntioned, was withdrawn from the bank, and has not been placed out on any security; it remained in the hands of the above-named Seth Eccles till he died in 1822, when it came to his son, Thomas Eccles, who still holds it. He distributes $£ 8$ yearly, as the interest thereof, in the same manner as his father formerly did, amongst such poor persons of Alston, or the neighbourhood, as apply to him about Christmas. Seth Eccles was a Roman Catholic, and his son is of the same persuasion; but the distribution is not confined to persons of any particular religion."-Extract from "The Charities in the County of Lancaster."

\section{Township of Dilforth.} ROADES'S CHARITY.

Frances Roades, ${ }^{2}$ by her will bearing date 1 st February, 1696, and proved in the Archdeaconry Court of Richmond; reciting that she was possessed of a certain parcel of land, whereon she lived then, desired that her father-in-law, George Singleton, should have the house wherein she then lived for his life; and all the rest, residue and remainder thereof, with the house (so limited to her father), after his death she appointed to be given to poor distressed housekeepers of Dilworth, for all eternity.

By indenture of feoffment, bearing date 22nd December, 1801, between John Cottam, of the one part; and the Rev. Robert Parkinson, of the other part; reciting that the said John Cottam was entitled to, and in receipt of the rents of the hereditaments, thereinafter mentioned, upon the trusts contained in the will of the said Frances Roades, and that he was desirous of appointing new trustees for the management of the said charity, and a perpetual succession of them, in manner thereinafter mentioued, the said John Cottan granted and enfeoffed to the said Robert Parkinson and his heirs, a messuage in Dilworth, with a barn and outbuildings, and four closes or parcels of land, containing about three acres, customary measure, thereunto belonging, to the use of the said Joln Cuttam and Robert Parkinson, and their heirs, upon trust to nominate another fit person to be a trustee with them, and that from time to time, upon the death or refusal to act of any trustee,

WWidow of John Roades, gent., a well-known man in Ribchester. 
the trustees should momiuate another person, so as to keep up the number of three, and that such nomination should be entered in a book, wherein should also be entered all such orders and regulations as the trustees should from time to time think proper; provided, that when any trustee should be appointer in lien of the said John Cottam, or such of his family or kindred as were thereinafter mentioned, there should be any of the family or kindred of the said John Cottam, entitled to an estate in Ribchester, called Know ${ }^{1}$ Green, near adjoining the said premises, such person should be appointed; and it was thereby agreed that the said trustees should manage the said lands, and superintend the letting and repairing thereof, as they should thiuk proper, and should apply the rents, after deducting all necessary charges, upou the trusts mentioned in the will of Frances Roades.

No third trustee appears to have been appointed in the manner directed by this deed till 19th June, 1823, when Mr. Cottam and Mr. Parkinson, by an entry in the book of charity, appointed Mr. James Dilworth to be a trustee jointly with them.

The charity premises consist of a house and shippon and four closes, containing about three acres (customary measure of seven yards to the perch), now in the oceupation of Thomas Eastham, as yearly tenant, at the rent of $£ 99 \mathrm{~s}$. per annum, the trustees doing the repairs and paying one-half of the taxes.

The same tenant has held the premises since 1804, at the same rent, and before that time at $£ 8$ 8s. per anuum. It is stated by the Rev. Mr. Parkinson ${ }^{2}$ and M[r. James Spencer, that the premises have not been well managed by the tenant, but that they think them worth about $£ 14$ per annum, but that $\mathrm{Mr}$. Cottam has hitherto been unwilling. to have the rent raised. In 1823 , the buildings were put into a good state of repair at an expense of abont $£ 14$; a small quantity of timber was cut and sold from the property in 182.4 to the amount of $£ 210 \mathrm{~s} .6 \mathrm{~d}$., which was brought to account.

The trustees meet on the 20th December annually, and, after deducting the sums paid for repairs and for taxes, and some charges for the expenses of the meotng they distribute the residue of the rents

${ }^{1}$ Knowle.

${ }^{2}$ Curate of Longridge. 
amongst all the poor of the townslip of Dilworth in sums usually varying from about $2 \mathrm{~s}$. to $5 \mathrm{~s}$. At the last meeting in December, 1824, a sum of $£ 27$ s. was reserved by the trustees to pay for some repairs not then completed. In the accounts of the year 1824, two sums of $£ 1$ 8s. 9d. and 13s. $8 \mathrm{~d}$. were charged as the expenses of the meeting held that year. Nearly the whole of that expense was incurred by Mr. John Cottam, one of the trustees, who came over from Prestou for the purpose of attending the meeting, Mr. Cottam having sold the estate which he formerly held, called Know Green, ${ }^{1}$ several years ago, and now residing at a considerable distance from Dilworth. Under these circumstances it seems that it would be for tho advantage of the charity if he were to resigu the trust in favour of some persou resident in the neighbourhood, who would concur with the other trustees in letting the estate at its full value.

TOWNLEY'S CHARITY.

Henry Townley, by will, dated 23rd January, 1776, bequeathed all his personal estate, after payment of his debts and funeral and testamentary expenses, to Cuthbert Siugleton and three others, their executors, administrators, and assigns, upon trust, to dispose of the same, and place out the produce upon good security, and to pay the yearly interest thereof, for ever, after the decease of certain persons therein mentioned, to such poor necessitous persons, having legal settlements in Dilworth, as they in their discretion should think proper objects, on every 21st December ; aud when any one or more of the said trustees should die, he directed the survivors by a memorandum, iu writing, to nominate such substantial persons, inhabiting in Dilworth, as they should think fit, in tho room of such person or persons so dying, to act in conjunction with the survivors in the trust thereby reposed in them.

The residue of the personal estate of Henry Townley is understood to have produced the sum of $£ 100$, but we have not been able to discover any authenticated account thereof. The sun was lent out on bond till about two years ago, when it was agreed by the inhabitauts of the township to call it iu and apply it to the building of a workhouse, which was erected for the townships of Ribchester, Dutton, Dilworth,

${ }^{1}$ Knowl Green. 
and Hothersall. From that time, the yearly sum of $£ 410$ s., which was the amount of interest previously received, has been paid out of the poor's rates. No memorandum of this transaction has been entered in the books. The contribution of the township of Dilworth towards the building of the house was $£ 325$.

Trustees have been from time to time appointed in writing by the survivors to make up the number of three. At the time of our enquiry, in August, 1825, there was one vacancy.

The interest is received from the overseers, and is distributed by one of the trustees, on the 21 st December, amongst such poor persons of the township and in such proportions as is determined at a meeting of the trustees, held previously for the purpose. The sums given to each person generally vary from 1s. 6d. to 4s.-Extract from "The Charities in the County of Lancaster."

This sum (£4 10s.) is not, I understand, now paid out of the rates. Why, I do not know, as the papers bearing on the matter have been mislaid. It is certainly a subject which demands some explanatiou from the responsible parties.

The population of Longridge was, in 1650,700 (140 families); in 1801, 1000-Alston 476, Dilworth, 524 ; in 1811, 1453-Alston 592, Dilworth 861 ; in 1821, 1727-Alston 758, Dilworth 969; in 1831, 1718-Alston 844, Dilmorth 874; in 1841, 1652-Alston 976, Dilworth 845 ; in $1851,1792-$ Alston 807 , Dilworth 833 ; in 1861, 2057 Alston 1098, Dilworth 959; in 1871, 3067-Alston 1337, Dilworth 1730 ; in 1881,3705 -Alston 1589 , Dilworth 2116 ; and in 1888 (estimated) 4160 . 
CHAPTER VI.-OLD HALLS AND OLD FAMILIES.

Hothersall Hall-Joseph Gillow-Hothersalls, 1199-1740-John Hothersall, captain-

"Younge Mr. Hothersall"- The Leckonby's -The Phipps's-Pedigree of the Hotbersalls-Bro. T. Hothersall, S.J.-Rev. W. Hothersall, S.J.-Sir WV. Vavasour-Hothersall boggart-MIr. Wilkinson-Jonathan Openshaw - Memorial-F. Openshaw, J.P.-Pedigree of Openshaws-Cattam Hall-Rev. T. Cottam, S.J.Rev. L. Cottam-Pedigree of Cottams-IVritten Stnne--The Ratcliffes-- Dutton Hall-The Torvnleys, 1400-1730-Pedigree of Townleys - High House-Hey House

-The Roades's-Buckley Hall-Rev. Fr. Holden-Rev. N. Sanderson-Rev. Seth

Eccles, D.D.-Dewhirsts, of Alston.

Ir giving an account of the old halls and old families in the district, after full consideration, I have thought it desirable to set apart a separate chapter for them. I have, however, been compelled by exigencies of space to omit any reference to Salesbury Hall, Osbaldeston Hall, and the numerous old halls in Goosnargh.

I shall in this chapter, then, deal with the Hothersalls and Openshaws, of Hothersall Hall ; the Cottams, of Knoll Hall ; the Radeliffes, of Written Stone; the Duttons and Townleys, of Dutton Hall ; the Sandersons, Holdens, Ecclı's, and others.

\section{Hothersall HaLi.}

Hothersall Hall, the seat of Frederick Openshaw, Esq., J.P., is a modern, plain, and unpretentious building. But on its site existed the old hall, long the family residence of the Hothersalls, the Lords of the Manor of Ribchester. Mr. Gillow, of Bowdon, in his "Bibliographical Dictionary," gives the following interesting account of the old hall and itsformer owners, the Hothersalls:-

The manor of Hothersall, in the joint township of Alston-cnm-Hothersall, belonged to the family before the invasion of the Normans, and the mill, which now stands by the banks of the Ribble, occupies the site of the ancient manor-house. It had its chapel, its secret hiding places, its ghost; and it has gathered round it memories and traditions which time-worn stones, carvings, and inseriptions still tend to preserve. Allied by intermarriage with the Hoghtons, of Hoghton; Rishtons, of Dunkenhalgh; Cromelholmes, of Dutton ; 'Talbots, of Salesbury; Walnsleys, of Showley ; and other ancient Lancashire families, the Hothersalls could show as prond and unbroken a descent from the time of the Conquest as any other family in the county.

The only stone I have been able to find belonging to the old hall is the one bearing date 1695 , a photograph of which fronts this page.

In the Visitation of 1664-5, the Hothersalls are stated to have no arms; but from the stone, which evidently was placed over the entrance 


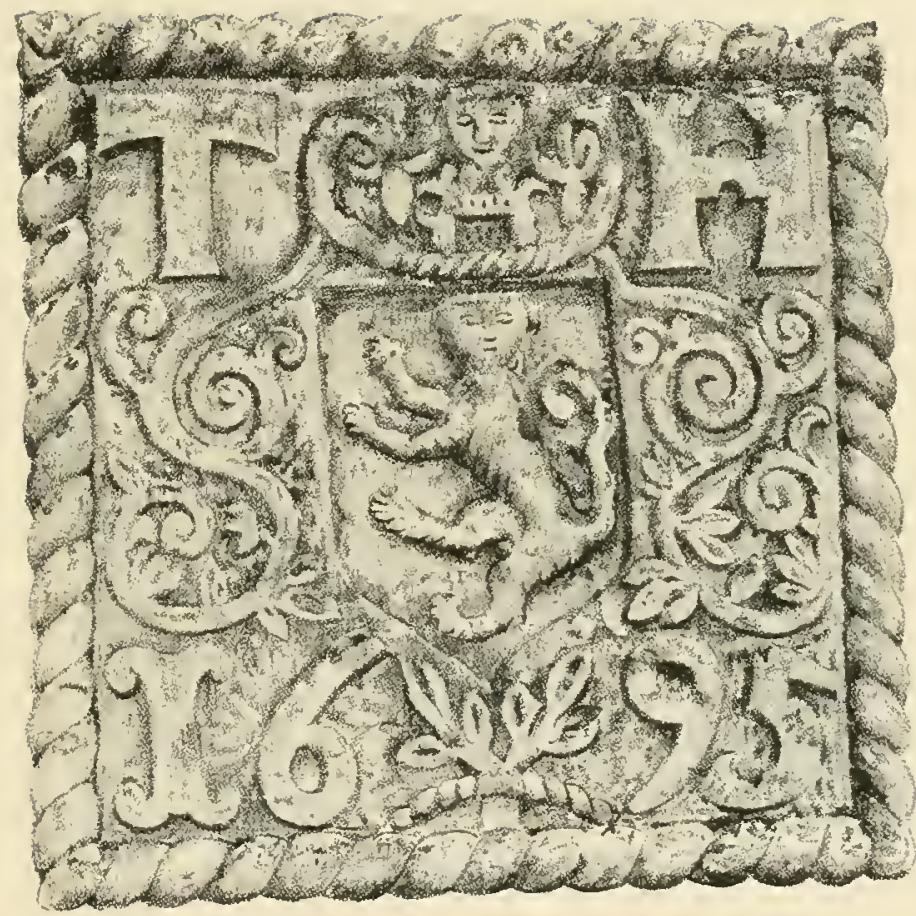



to the hall, they evidently had one. At any rate, they were one of the most ancient and celebrated families in Lancashire for five or six hundred years.

"The ancient family of Hothersalls," says Mr. Gillow, "was descended from Robertus de Hadreslrall, who held two bovates in Hadreshall. His son, Warinus de Hadersall, was living I. Johannes (1199-1200), and was the father of Thomas de Hedreshall, whose Inq. post mortem is dated 41 Hen. III. (1256-7).

Robertus de Hudreshall, son of Thomas, had issue a son, Thomas de Hodersall, who married 5 Ed. II. (1311-12) Margerias, filius Monsieur Ricardus do Hocton, de Hocton, filius Adae fuit Miles, and in the 'Tenente Duci Lancaster' of that year, it was found that ho held Hodersall 'per servicium $T_{\delta}$ per annum ad quatuor term.'

His son, Robertus de Hodreshall, in the Survey of 1320-46, held two oxgangs of land in Hodreshal, in soccage, on the same terms. Ricardus de Hodiersale, sou of Robertus, and Emma, his wife, were living 47 El $r$. III. (1373-4), and from him descended Robert Huddersall, Lord of the Manor of Hothersall, whose Inq. post mortem is dated 19 Eliz. (1576-7), and whose son John married Aune, daughter of Joln Talbot, of Salesbury, Esq., by his first wife, Aun, daughter of Hugh Sherburn, of Stonyhurst, Esq. His name appears in a list of obstinate Catholic recnsants reported in Queen Elizabeth's reign."

Mr. Gillow appears to have omitted the name of Richard Hothersall, whose Inq. post mortem was taken at Preston, on 4th Oct., 1610. John Hothersall was therefore the son of Richard Hothersall, and grandsen of Robert Huddersall, who died in 1576-7.

"Jo., son of Thomas de Huthersall, to Nicholas, of Huthersall, father, all his lands in Huthersall, Ribehester, ${ }^{2}$ entailed with remainders 23 E III [1350]."

Ade de Hodersall was executor of the will of Johannes de Ardern in 1385 , and, along with Nicholai Brockhole, was executor of the will of Sir Robert Clifton, also in 1385.

"Robert Hothersall, letter of attorney to give seizen to John de Hoghton of all his lands in Hothersall and Ribehester-3 Hen. V. [1416].".

${ }^{1}$ Tyldesley Diary. ${ }^{2}$ Towneley MISS. sDitto. 
In 1432 Ughtred Hothersall was one of the executors of the will of Sir John Talbot and of Isabella Talbot.

"In Ang., 1230, Walter de Motun, and Amab'l, his wife, gave half a mark for a writ of novel disseism 'versus Swanum de Huddleshale de ten' in Ribbecester.'"

Inquisition taken at Preston, 4 Oct., 1610 , it was declared that Richard Hothersall was seized in fee of a capital messauge, called Hothersall Hall, situate in Hothersall, 5 messauges, 6 cottages, 30 acres of land, 10 acres of meadow, and 30 acres of pasture, with the appurtenances in Hothersall, also an acre of land iu Ribchester; which are held of the King in fee and common socage by 5s. rent paid jearly to the hands of the General Receiver of the Duchy of Laucaster, and are worth fee ann. (clear) 40s. Richard Hothersall died 28 Jan., 1609-10, and John Hothersall, gentleman, his son and next heir, is now aged 25 years and more $(1610) .^{3}$

"John Hothersall, captain in the royal army, born in 1614, was the eldest son of Thomas Hothersall, of Hothersall Hall, co. Lancaster, Esq., by Bridget, daughter of William Haydock, of Cottam Hall, Esq., and his wife Bridget, daughter of Sir Richard Hoghton, of Hoghton Tower, Knt.

"At the time of Dugdale's Visitation of Lancashire in 1664, Captain Hothersall's father was still alive, at the age of about 80 . Two of his sons had lost their hives in defence of their sovereign-John, the captain, at Greenhalgh Castle, near Garstang, in 1645; aud Lieutenant George, the secoud son, at Liverpool, in 1644. His third son, William, resided at Alston, and, with his wife Grace, suffered severely under the laws against recusants. Indeed, the family was always noted for its staunch adherence to the faith. A sister to the captain, Elizabeth, became the wife of her cousin, Cuthbert Haydock, of Cottam, Esq.

"Captain Hothersall married Margery, daughter of James Wall, of Preston, Esq., by Isabella, daughter of William Travers, of Nateby Hall, Esq., and after he was slain in 1645, his widow married at Woodplumpton, Feb. 13, 1647, Robert Haydock, of Cottam, gent. His only surviving son and successor, Thomas Hothersall, Esq., born

1"Lanc. Inqu." 
Nay 10, 1644, married, Jan. 9, 1688, Catherine Lancaster, of the family seated at Rainhill Hall, but she was, perhaps, a second wife. He died in Jan., 1719. His eldest son, John, was taken prisoner at Preston, Nov. 13, 1715, after the defeat of the Chevalier de St. George, but affected his escape, and, being outlawed, lived in retirement with his sister, Mrs. Leckonby, at Great Eccleston, where he died unmarried, between 1740 and 1750. Besides a younger son, George, who died in his youth, there were five daughters-Anne, Isabel, Margery, Sarah, and Grace. Of these, Anne was the mife of William Leckonby, of Leckonby House, Great Eccleston, Esq., and Nargery married Edward Winstanley, of Pemberton, gent. These two eventually became co heiresses to the estates, the Manor of Hothersall falling to the share of Mrs. Leckonby. Towards the close of the century the estate was sold, and has since passed through several hands, being now the property of the Openshaws, who have modernized, if not rebuilt, the hall." ${ }_{1.2}$

John Hothersall, gentlemen, or "Younge Mr. Hothersall," as he is ealled in the "Tyldesley Diary," was the younger son of Thomas Hothersall, Esq., of Hothersall Hall. He joined the rebels, and in 1715 was taken prisoner at Preston. He was nover married, and in 1736 was living with his sister, Mrs. Leckonby, of Great Eccleston, whose son eventually sncceeded to the Hothersall estates.

The Leckonbys became extinct by the marriage of the last danghter of this ancient family with T. H. H. Phipps, Esq., Wilts.

The last of this ald Catholic family was the mother of Miss E. M. Phipps, who resides at Leckonby Cottage, Great Eccleston.

The following references to John Hothersall are interesting:-

"June 10, 1714. Gave Jon. Malley and Jo. Parkinson 1s. pro subsistance. Dined in the cockpit with Mr. Clifton and others. Spent in wine 6d., pro dinner $1 \mathrm{~s}$. Gave ye fiddler 6d.; onn tickes, spent in the pitt, betwixt battles, 6d.; I won near 30s. Gave the ffeeder $1 \mathrm{~s}$.

\footnotetext{
1"Bihliographical Dictionary," Gillow, vol. III.

Mr. Gillow, in his notes on the Hothersall family, states that "Hothersall Hall was sold by the Leckonbys to the Martins."
}

This is incorrect. The Martins only farmed the land, the owners of the estate being the Allertons, from whom it passed to the Pedders and Culcheths, and finally to the Openshaws. 
Spent after the play was done with young Lord, Gabe. Hesketh, Hew. Whittingham, Jack Threlfall, Will Leckonby, Younge Mr. Hothersall, Young Ince, and others, itt beeing ditto's birthday, 3s. $6 \mathrm{~d} .{ }^{21}$

Mr. Gillow, to whom I am indebted for the pedigree of the Hothersalls, tell me in a letter that, "there is much that is uncertain about the earlier generations. The Hothersalls were more numerous than is generally supposed, and probably some confusion has occurred in consequence. However, it is original, and if you were to state that I have drawn it up, but do not consider it perfectly rehable in the earlier generations, it would be the safest course to pursue." Mr. Gillow also refers to the firmness with which this ancient Catholic family remained true to the faith, in spite of the innumerable persecutions to which they were subjected. "There was a chapel in the hall," he continues, "provided with several hiding places for the priests, who probably served it pretty regularly from the reign of Elizabeth to early in the last century."

"The present chapel at Alston Lane may be said to have origiuated from that in the Hall."

Two of this family were Jesuits, as the following notices by Mr. Gillow show :-

"Brother Thomas Hothersall, Scholastic S.J., born at Grimsargh in 1642, was a son of William Hothersall, and his wife, Ann Slater. He studied at St. Omer's College, and thence proceeded to the Euglish College at Rome, which he entered as a convictor, October 15, 1665. After receiving minor orders he entered the Society, June 20, 1668. In 1683 he was sent to Maryland, and was employed in teaching until his cleath, in 1698, aged 56. He never became a priest.

"Father William Hothersall, S.J., probably of the same family as the above, was born May 19, 1725. He entered the Society Sept. 7, 1744. He was the last Jesuit Rector of the English College at Rume, from 1766 to the suppression of the Society in 1773. He died at Oxford, August 25, 1803."

" Tyldesley Diary." 



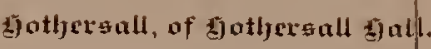

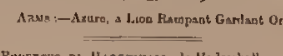

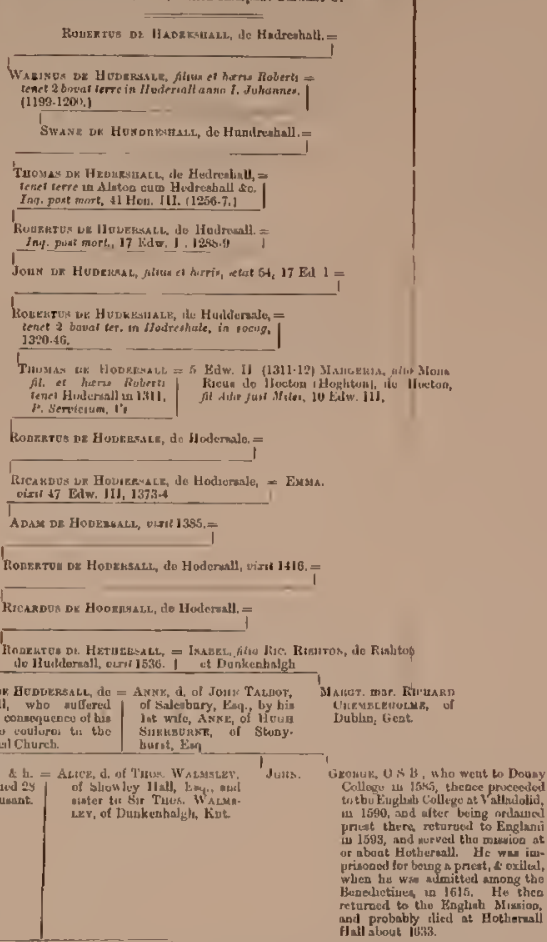

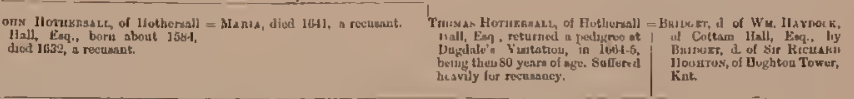

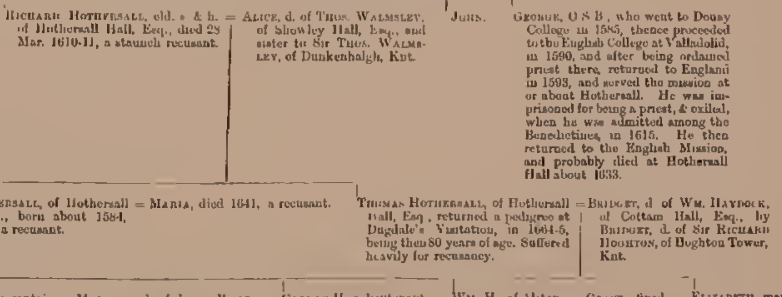

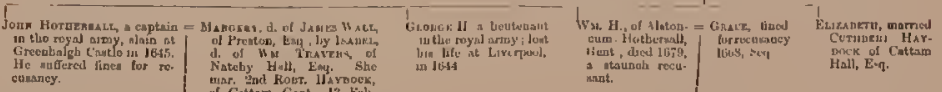

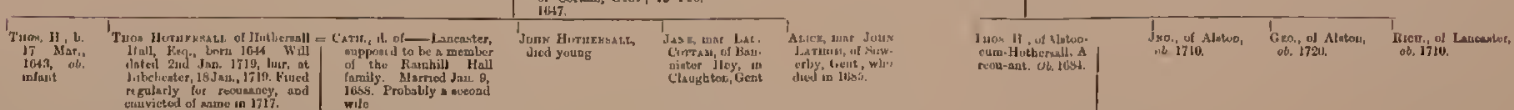

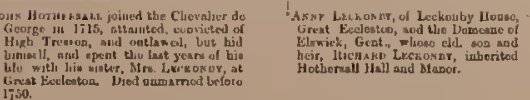


It has been said that the Hothersalls were staunch Catholics, and had suffered much for the faith. The following account of the liding of Sir Walter Vavasour, a great friend of the Hothersalls, is very interesting, and shows the risks the Catholics ran at this time in adhering at all openly to their religious convictions :-

"Sir Walter Vavasour, of Haslewood, Bart., was a Jesuit serving the mission in the Midge Hall district. At this period he resided in A]ston, perhaps with Richard Bilsborrow, who was outlawed for taking part in with the Chovalier de St. George in 1715, though it is pretty certain that Mr. Vavasour frequently said mass in the domestic chapel at Hothersall Hall, the seat of Thomas Hothersall, Esq., a cousin of the Haydocks, a celebrated Roman Catholic family, of Broughton. John Harrison, of Balderston, on Nor. 24th, 1716, laid an information before the Commissioners of Forfeited Fistates, in which he stated :'John Harrison did, on Friday, 1'th Nov., 1715, at Preston, see Mr. Vavasour (brother of Sir. Walter Vavasour), who is said to be a Jesuite, appear there openly in the streets and particularly did see him go into the White Bull Inne, in Church Gate Street, in company in the several persons who had all or most of them cockades in their hats-that the said Mr. Vavasour had then a sword by his side,' ete. On the previous Oct. 17, George Green, the High Constable of the Hundred of Amounderness, alvised the Commissioners that 'Mr. Vavisor, who is a reputed priest, harboured in our town [Alston-cum-Hothersall.]' Sir Walter Vavasour afterwards succeeded Fr. James Thomson, S.J., to the mission at Preston."

"Edward Winstanley, of Alston, sworn this 18 July, 1718, saith that he knows Mr. Vavasor, who lives in one of the four houses called the Bough, and that he hath seen the said Vavasor perform the ceremony which is called mass in the said house.

"Joseph Key, of the same, saith that he knows Mr. Vavasor, that he has lived about 15 years, and hath seen him officiate as a Romish priest at the altar in the service of the Eucharist. That Vavasor is tenant to this deponent, and pays him $£ 3$ per aunum, and this deponent is tenant to James Bleasdale [and] is to pay $£ 25$ per annum by lease, which expired last year.

"The Haydock Papers." 
"Bartholomew Taylor, of the same, hath known Vavasor frequently say mass at the house where lives Bartholomew Taylor." 1

There are two traditions respecting the old hall which cannot well be passed over. It appears that at Hothersall Hall the devil had undertaken to oblige some inhabitant with whatever he should command in return for a surrender of the daleman's soul when it left the earth. He had been allowed three wishes-what they were is not recorded-but one thing that the Hothersall gentleman had asked for was a rope from the sands of the River Ribble, which was close at hand. In case of failure his Satanic Majesty had consented to be laid under one of the laurel trees growing in the valley.

The devil and mate then went to the strand, In a jiffey they twisted a fine rope of sand, And dragged it along with them over the land

But when they brought the rope to be washed,

To atoms it went-the rope was all smashed!

As the rope was not satisfactorily completed, the "man of Hothersall" escaped the devil's clutches, and the dark gentleman was buried, according to agreement, under one of the trees in the valloy.

Mr. Wilkinson, referring to the Hothersall Hall boggart, says "it is understood to have been 'laid' under the roots of a large laurel tree at the end of the house, and will not be able to molest the family so long as that tree exists. It is a common opinion in that part of the country that the roots have to be nourished with milk ou certain occasions, in order to prolong its existence, and also to preserve the power of the spell under which the goblin is laid." The laurel here seems to have been invested with the mythical properties of the ash and rowan trees-

Towan, ash, and red thread

Keep the devils frae their speed.

It is also stated by Mr. Wilkinson that "it is a common practice with the housewives in this district to tie a piece of rod worsted thread round their cows' tails previous to turning them out to grass for the first time in the spring. It secures their cattle, they say, from an evil eye, from being elfshot by fairies, etc."

It is some time since, I ought to add, these tales were believed in. Now, no one pays any heed to the Hothersall boggart.

iMS. v. 1. 


\section{Jonatuan Openshaw.}

On Thursday, March 2nd, 1882, the grave closerl over the remains of one who, most truly, was one of "nature's noblemen." Jonathan Openshaw, Esq., of Hothersall Hall, Ribchester, and Waterloo, Bnry, was looked npon as a friend, not only by his associates, but also by the poor, to whom he gave so largely and so generously. Descended from an old Bury family, Mr. Openshaw was born at Bury on the 7 th May, 1805. He carried on business at lis uative place as a woollen manufacturer. He was a toiling and elever business man, and soon became wealthy. Retiring from business, he purchased the Hothersall Hall estate in 1853 , and gradually becanio one of the largest landed. proprietors in the district. He pulled dewn the old hall--the historic residence of tho Hothersalls-which was in a dilapidated state, aud alse greatly improved his land, and was known as a just but generous landlord. In politics Mr. Openshaw was an exceedingly keen Couservative of the "good old school," and largely contributed to the success of Messrs. Holt and Starkie in 1868 anil 1874. As a Churehman Mrr. Openshaw figures in the ecclesiastical chapters of Longridge and Ribehester. But he will be most remembered as a generous benefactor of the poor. His charity rias without limit. No deserving case escaped his fostering care.

The scene at tho funeral was striking. In spite of the pitiless weather, people from all the country-side were assembled to pay the last token of respect to Mr. Openshaw, and showed by their manifestations of grief that they mourned for one whose loss they keenly felt.

We think it little to the credit of the people amongst whom he lived, and for whom he did so much, that five years should elapse betreen the erection of a memorial to him and his death. In 1887 a plainvery plain-and rather unsightly drinking fountain was orected at the junction of the Longridge, Ribchester, and Preston roads, on which is cut in plain letters the following inscription :-

$$
\begin{gathered}
\text { In MIemory of } \\
\text { JONATHAN OPENSHAW, EsQ., }
\end{gathered}
$$
Of Hothersall Hall Who died Fets. 25th, 1882 ; Erected by his Tenantry and a few friends, In recornition of his kinduess to the poor. 1887.

There is also a tablet to his memory in Ribchester Ohurch. 


\section{Frederick Opensmaw, J.P.}

Frederick Openshaw, Esq., J.P., succeeded to the estates of his uncle. In the prime of life, he devotes himself to improving his estate, 300 acres of which he farms himself. His cattle sales are known all through Lancashire. In politics a Conservative and in religion a Churchman, Mr. Openshaw is, of course, popular among the "Church and Tory" people of Ribchester; but by his kindly and genial qualities he is liked and respected by all who know him.

\section{The Cottans, of Cottam (Kinols) Hall.}

Cottam Hall, the ancient residence of the Cottams, situated close to Knowle Green Cliurch, on the high road to Hurst Green, is still standing, though it has been converted into a modern farm house. Baines refers to the house as "Knoll Hall."

From a careful inspection of the house and buildings, which now bears the not inappropriate name of the "Manor House," I can find no date, or inscriptions on the stones or $0 ! d$ woodwork. It is probable that, when the hall underwent renovation early in the present century, any memorial stones there may have been were removed. Some years ago, I was informed by the wife of Mr. W. Bradley, the present tenant, a party of Catholic clergymen made a close inspection of the place, with a precisely similar result to my own examination.

The hall, which, in the account given below of the Rev. Thomas Cottam, is described as "Dilworth Hall," was probably built early in the 14th century as mention is made of it in anciont MSS. It has been a fine place judging from the present house, which is in a remarkable good state of preservation, the style of architecture being that of the Jacobean period. Numerous tales, apparently well authenticated, are current in the Knowle Green district about the Cottams. It is said that during the latter part of the last century, Cottam, the then owner of the estate, kept up a large stud of horses, and a fine pack of hounds. He was a frequenter of the Stouyhurst Buck Hunt meets, celebrated, strange to say, by a namesake of the Cottams-Cottam, the schoolmaster and poet of the neighbouring parish of Hurst Green. 
Authorities :

Registers at Bury,

"Ducatus Lancestria," cte.

Compiled by 'T. Openshaw, Esq.

\section{(1) preyty}

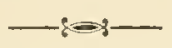

Opynscha of the Schae (born about A.D. 1370)

Richard Opynscha

(born about 1410)

Opynscha

(boru about 1440 )

Juhn Openscha

(born about 1470 )

Thomas Opeuscha = Elizabeth Sharples,

(burn about 1500) of Sharples

Lanwell Upenscha

\begin{tabular}{l}
$\frac{(\text { died 1607) }}{1}$ \\
James Openshawe \\
(born abont 1550) \\
$\frac{\text { John Openshawe }}{\mid}$ \\
$\begin{array}{c}\text { James Openshawe } \\
\text { (born 1639) }\end{array}$ \\
James Openshey \\
\hline
\end{tabular}

John Openshaw = Elizabeth, dau. of (born 1704) Oliver Ormerod,

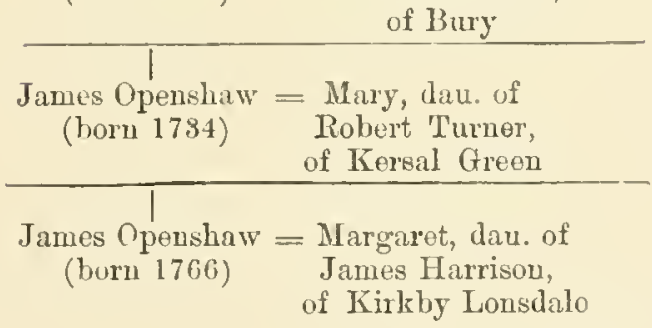

\begin{tabular}{|c|c|c|}
\hline $\begin{array}{l}\text { William } \\
\text { (born } \\
\text { (died }\end{array}$ & $\begin{array}{l}\text { Opensbaw = Elizabeth, lau. of } \\
1803) \\
1868\end{array}$ & $\begin{array}{l}\text { Jonathan Openshaw } \\
\text { (boru 1805) } \\
\text { (died 1882) }\end{array}$ \\
\hline
\end{tabular}

Frederick Openshaw = M. E., dau. of (born 1838) Eelmund Hardman, Chamber Hall, Bury. 

Mrs. Bradley also told me that her aunt, who was a servant of the last of the Cottams, used to tell her how Mrs. Cottam, the wife of the last of the Cottams, died through being choked with a goose-bone.

About 1800, Knoll Hall estate passed into the hands of Mr. W. Boardman, of Farington, gentlemau; from whom it descended to the Bashalls, of Southport, who are the present owners. For some seventy years an old family of yeomen, named Hesmondhalgh, were the occupiers of the farm; Mr. W. Bralley being, as I have said, the tenant at the present time.

Rev. Fr. Thomas Cottam, S.J.

"Father Thomas Cottam, S.J., martyr, was the son of Lawrence Cottam, of Dilworth and Tarnaker, gent., and his wife Ann, daughter of Mr. Brewer, or Brewerth, of Brindle, co. Lancaster, who, after her husband's death, married William Ambrose, of Ambrose Hall, in Woodplumpton, gent.

This ancient family had been seated at Dilworth for many generations, and returned a pedigree at St. George's Visitation of Lancashire in 1613. The martyr's brother, John Cottam, succeeded to the estates, and resided at Tarnaker. Both he and his wife Catherine, daughter of Mr. Dove, of Birtwood, in Essex, frequently appear in the Recusant Rolls with their only child, Priscilla. The latter married Thomas Walton, of Walton-le-Dale, co. Lancaster, gent., and was the mother of James Walton, who was ordained priest at the English College, Rome, in 1633, and used the alias of Thomas Cottam.

Though other members of the family appear in the Recusant Rolls, Fr. Cottam's parents were Protestants, and, being people of substance, could well afford to give their son a liberal education. Having made his rudimental studies, he was entered at Brasenose College, Oxford, where he passed B.A., March 23, 1568.

After the completion of his studies he was appointed to the mastership of a noted free grammar-school in London. Here he formed an intimate friendship with Thomas Pounde, Esq., of Belmont, and was soon converted by that noble confessor of the faith, who suffered an imprisonment of about thirty years' duration, and was admitted to the Society of Jesus in prison, but was then at liberty. 
Accordingly he resigned his mastership and loft England for Douay College, where he repeated his philosophy and studied theology for some years.

His ardent desire was for the East Indian missions, and with this view he left Douay for Rome, where he obtained admission to the Society of Jesus at St. Andrew's as a preparatory step, on April 8, 1579 In the sixtl month of his noviceship he was attacked with a consuming and lingering illness, and he was sent by his superiors to Lyons to try if a change of air would restore him to health. But the sickness increasing, he appeared unfit for the Society, and therefore he was dismissed the novitiate.

Nr. Cottam, as soon as he was able, returned to Douay College, which in the meantime had been translated to Rheims, and there he was ordained priest, in 1580, and forthwith was sent to the English mission. Ho arrived at Dover in Jnne of that year, and was immediately arrested. To avoid expense, the Mayor of Dover requested a merchant, named Havard, travelling to London, to carry him a prisoner to Lord Cobham. Havard, who in reality was Dr. Ely, Professor of Cauon and Civil Law in the University of Douay, did not, of course, intend to deliver him up, but Mr. Cottam's scruples and other circumstances resulted in his surrendering himself to Lord Cobham's deputy. He was carried to the court at Nonsuch, or Oaklands, and, after five days' conference with various Protestant ministers who laboured in vain to convert him, he was committed to the Marshalsea for religion, and not on the more ordinary charge of treason.

In the Marshalsea he ras brutally tortured, and then removed, December 25, 1580, to the Tower to be racked and undergo the torture of tho "Scavenger's Daughter," \&c. This was not done under the usual pretence of extracting secret troason, but purely on account of refusal to conform and confess his private sins to his tormentors, as he boldly affirmed to their faces at his arraignment.

After a long coufinement ho was amaigned at Westminster Hall, November 14, 1581, with Fr. Campion and others, and was condemned to death for his priestly character. His execution was deferred for 
State purposes until May 13, 1582, when he was lragged on a hurdlo from Newgate to TJbnrn, with three other priests, Villiam Filbie, Luke Kirby, and Lawrence Richardson, and was there hanged, drawn, and quartered, aged 33.

Challoner, and most authorities, do not treat him as a Jesuit, but D1. Oliver and Bro. Foley have included him in the "Collectanea S.J.," quoting some authorities for the assertion that the martyr" was readmitted into the Society in prison."-(Gillow's, "Biblio. Dict." Vol. 1.)

\section{Rev. Fr. Lawrexce Cottay.}

"Cottam, Laurence, son of Henry, of Lancashire, aged 19. Admitted with the last (Richard Norris). Took the oath snd receired minor orders in 1679. Ordained subdeacon and deacon in July and August, and priest September 7, 1681. He left for the Fathers of the Mission (ad Patres Missionarios), January 22, 1684, and on April 13, following, became chaplain to the Cardinal Protector.

"Laurance was son of Henry and Mary Cottam; he was born at Thornley, Lancashire, and was principally educated at Clitheroe School. His parents were of the middle class, as were likewise his relations, and all were Catholics."-Students' Rephies (Foley's "Diary and Pilgrim Book.")

\section{Lawrence Cottay.}

Lawrence Cottam was declared, at the Inquisition held in 1619, to be seised of 1 messauge and 16 acres of land, meadow and pasture, in Dilworth, which are held of Richard Houghton, Knt., in free and common socage and $2 \mathrm{~s}$. rent and worth per ann. (clear) $10 \mathrm{~s}$.

Lawrence Cottam died 17th Jan., 1618-19, and Thomas Cottam, his son and next heir, is aged 30 yenrs and more.

\section{Thomas Cottam.}

At the Inquisition held in 1621, it was declared that Thomas Cottam, late of Dilworth, gentleman, long before his death, was seised in fee of 1 messauge, 20 acres of land, 10 acres of meadow, and 30 acres of pasture in Dilworth. The premises in Dilworth are held of Richard Houghton, Knt. and Bart., in free and common socage by 
fealty and the yearly rent of $2 \mathrm{~s}$. for all services, and are worth per ann. (clear) 40s. He died at Dilworth, 16th Feb., 1620-21. Lawrence Cottam is the son and next heir, and was aged 15 years.

John Cottam, Ribchester, $£ 14$ 5s. 8d. Non-juror, 1745

DiLWORTH.

Lawrence Cottam, gent., leasehold house at Ribchester, $£ 27$.

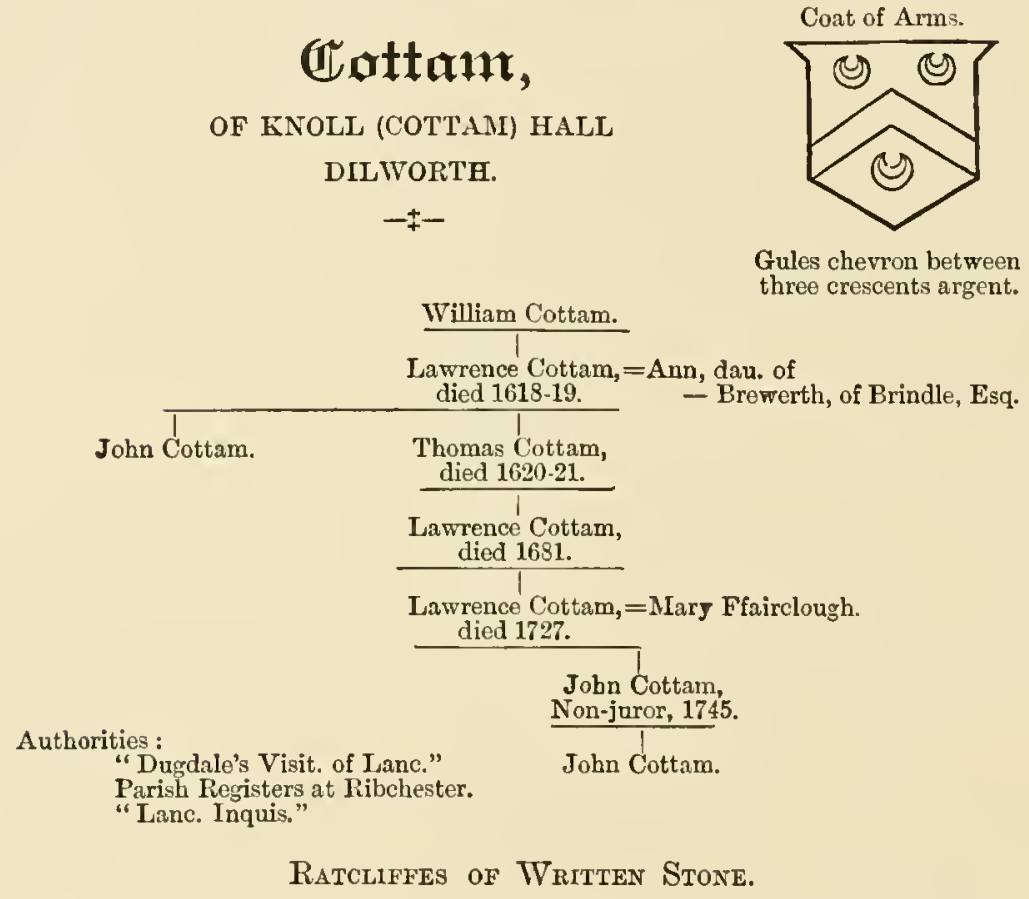

Written Stone House is a modern building. No traces of the old residence of the Ratcliffe family are now to be seen. A full account of the "Written Stone," laid, in 1655, by Ralph Ratcliffe, is given in Chapter I. The following reference to this family is interesting:-In the journal of Nicholas Assheton, of Downham, 
Esq., for 1617-18, there oceurs the following entry :- "March 15, 1618, Cozen Assheton, Cozen Braddyll, Mr. Radeliffe, cum aliis to Longridge Bottom."

Inquisition taken at Preston, 1617, it was declared that Edward Ratcliffe, at the time of lis death, was seized in fee of 1 messauge, 1 cottage, and 16 acres of land, meadow and pasture, with the appurtences, in Alston. He died 7 th Feb., 1617.

The messauge and other, the premises in Dilworth, are held of Richard Houghton, Knt. and Bart., in free and common socage by fealty only, and are worth per ann. (elear) 20s. As are also the premises in Alston. Henry Rateliffe is the son and heir of the aforesaid Edwarl, and is aged 21 years, 11 months, and 19 days. Ann, his widow, is yet alive at Dilworth.

The last of the Ratcliffes resident in this district was George Ratr.liffe, who for a long time was a well-known man. He was overseer of the poor for Alston; was frequently chapelwarden, and took a prominent part in all local matters. The present owner and oceupier of the old residence of the Rateliffes is Mr. William Bourn, whose ancestor built the present house.

\section{Detton Hall.}

Dutton Hall is a fine and spacious bnilding of the age of Charles II, situate in Gallow's Lane, Dutton. The Hall is one of the best preserved old halls in the district; and must have been a truly noble residence in the time of the Townleys. It is well situated on the slope of the hill; the original gateway is still standing, while the centre tower and battlements look remarkably well.

Baines says Dutton Hall "was sucessively the property of the Duttons, Claytons, Tomnleys, and Joules;" but the present building was erected by the Townleys.

From the charters given in Whittaker's "Whalley," we find that William de Dutton granted lands to William Moton and others (13501370). In 1373 , H. de Clayton regrants the Manor of Dutton to Tichard de 'Tomnley. 
The Townleis of Dutton Hall.

The Townley family was a branch of the Townleys, of Townley. Dr. Whittaker says "that the Manor of Dutton continued with the Townleys, of Townley nntil it was given to Richard Townley, a younger son, in whose descendants it remained till the death of Menry Townley, whose surviving daughter died in extreme old age, Anno 1799."

Walton, in his Familice Lancastriensis says that Richard Townley, of Dutton, was the first of the Dutton branch, descended from the parent stock. This Richard Townley was living early in the 15 th century, circa 1400. Some authorities, however, make Henry Townley (who lived two generations later), the first of the Dntton Townleys.

Mr. W. A. Abram states that, "'Henricus Tomneley' was a juror on the Inquisition taken at Blackburn, after the death of Richard Towneley, Esq., on the 30th April, 1445. Henry Townley, of Dutton, by Margaret his wife, had a son and heir Thomas; and was living in $1474 . "$

Nothing is known, so far as I am arare, of Thomas Townley. His son, Richard Townley was married twice. By his first wife he had three sons and one daughter. The third son Robert was a clerk. By his second wife Richard Townley had no issue.

Both in Dugdale's Fisitation and the Familice Lancastricnsis, John Tomnley is named as second son of Richard. But Mr. Abram seems to prove conclusively that he was the eldest son, and, dying without male heir, was succeeded in the estates by his brother Henry. ${ }^{1}$ In tho the wills published by the Surtees Society, is the subjoined copy of the will of John Townley.

Johy Thwrley Parochi de Ribchester.

22 . - 1562. I John Townlay of Dutton of the parishe of Kybchester, gentylman-to be buried in the parishe church att Rybchester-and forasmuche as elly person or persons havinge any capitall mease, lands, tenements, hereditaments holden in soccage or of the nature of soccage tenure and not havinge any capitall mease, lands, tenements, or hereditaments holden of the Queenes majesties by kuyght servis, or by soccage tenure in chefe, or the nature of socage tenure in chefe, nor of any other person or persons by knyght servis, shall aud may have full and free liberte, power, auctorite to geve, dispose, devyse, wyll, and declare by his

" Antiq. Notes." 


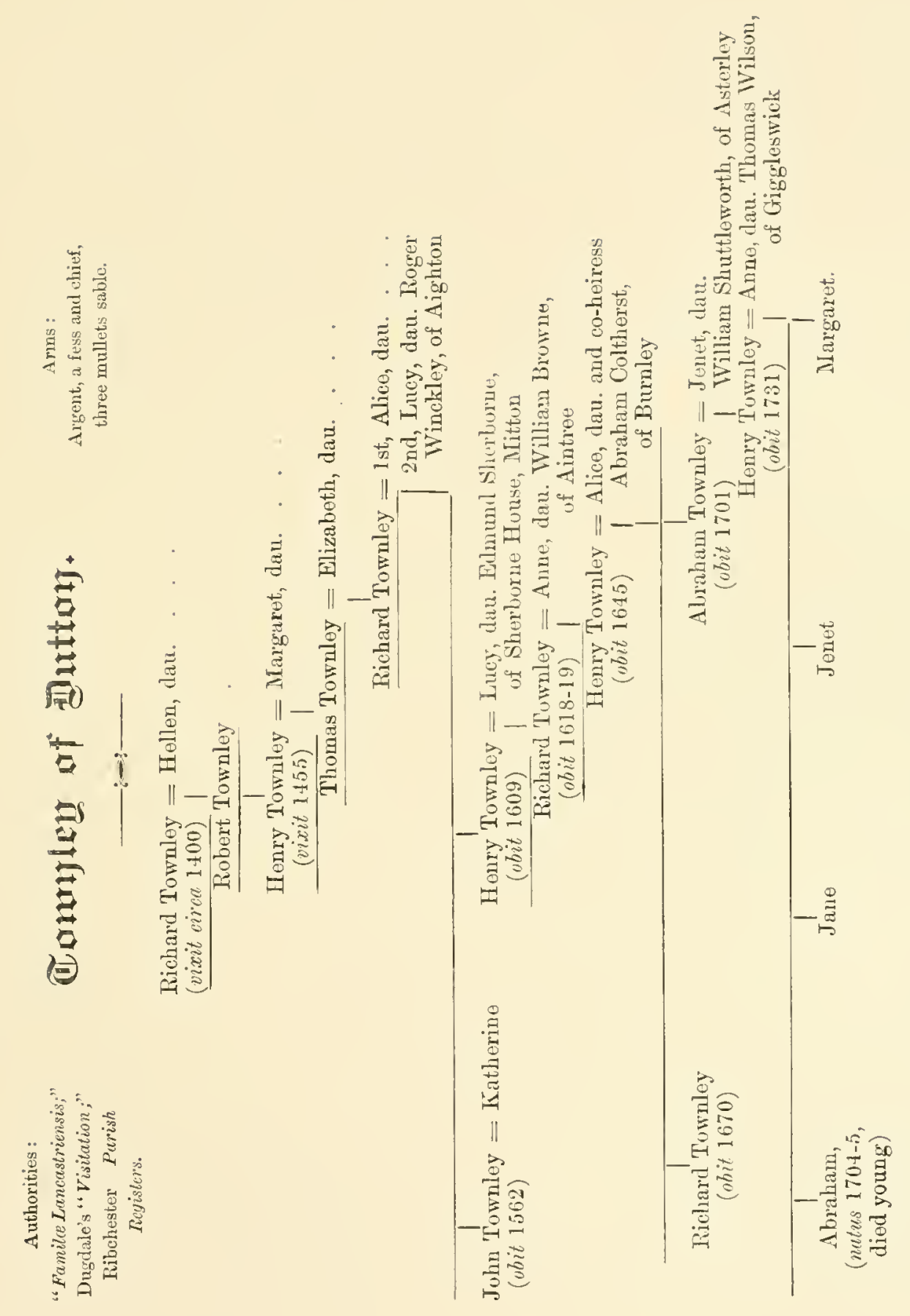



last wyll and testament all his said capitall mease, lands, tencments, and herditaments, or any of them, at his wyll, liberte, and pleasure, and allso that every person or persons havinge any capitall mease, lands, tenements of estate of inheritance, holden in knyght servis, shall and may have full power and auctorite by his last wyll and testament to wyll. - I the said John Towinlay, being seased of inheritance of certain lands in Dutton in socage, or in the nature of socage tenure, do give unto Kathe my wife __ of my lands, closes called the nerer Hand-feild, the further Handfield, the Wyddow genes, the Cow feild, the okin ridling, the Great and Little banks, Hemerlees and the Ponshones, and 2 closes of the Riagdens for 21 years, and then to come to my right heirs.-Also I wyll that a jd be geven to every person being present at the tyme of my buryall that wyllingly wyll take hit.-To every person $d$ wellinge with me at the day of my death one yeres wagesTo Jane my doughter ten ponnds. To Sir James Liungard, Vicar of Ribchester xiijs iijd. To Sir Jamys Mlore xs. To Sir Rychard Mersilen xs. The rest of my goods to Katherine my wife, whom l make my executrix_—My singuler good Mr. IIr. Juhn Talbot of Saylburye Esquier Supervisor, and I allso give for his paynes takings $x \mathrm{~L}$.

Inventory 1572 , ij payre of clammers, one foit eche, with togwthes, $x x d$. iij goubeyrons with one brouling iron xvjd. xiij. stannis and barels vjs viijd. iij Skelis, ij Collockis, ij pickeins, ijs. vij Kinoppis and twinels, one knedesshein, xxiiijs. For a hare, vijs. iiijd. V. sylver sponis, xvjs. Sum, Lxiijli. vs. vijel. He owes to Edward Ratcliffe vli. John Shirburne gentylman owes him vli. xiijs iijd. ${ }^{1}$

Henry Townley, the brother of John, as we have said, suceeeded to the estates. He had five sons by lis wife Luey, daughter of Edmund Sherburne, Esq., of Sherborne House, Mitton. "In the 22nd Eliz. (1579), Robert Seede, in right of Robert Lynells, had a suit with Henry 'Townley, Thomas Cooke, and others, coneerning a messauge and land and right of way in Ribchester, Fawney, and Langridge Moor." Henry Townley died at an old age in 1609.

Richard Townley, the eldest son of Henry, was the next lepresentative of the Dutton Townleys. He had five sons and three danghters. His widow, on his death, married Mr. Henry Hayhurst, of Ribchester. Richard Townley died 11 th Sept., 1618.<smiles>[AsH2][AsH2]</smiles>

"Surtees Society "Rich. Wills"853

${ }^{2}$ At the inquisition, held at Preston, 7 Sept, 1619 , Hichard Townley was declared to bave held lands in Dutton, of
R. Sherhorne, Esq., in socage by fealty R. also held premises in IIothersall of John Hothersall, gent.-Record Society- 
Henry Townley, the son and heir, married Alice, daughter and co-heiress of Abraham Colthirst, Esq., of Burnley, and had six rhildren. Henry Townley, of Dutton, probably leant towards the Royalist cause in the civil war (1642-51), and on a levy of arms for the Parliament in Dutton and Ribchester, about December, 1642, ' Henry Townley, of Dutton,' was required to furnish 'one muskett.' "' He died in 1645 .

Richard Townley was 15 years old on his father's death. He died unmarried in 1670 , agad about 40 years.

Abraham Townley, brother of Henry, succeeded to the family estates. He married Jennet, daughter of WV Shuttleworth, Esq., of Asterley, near Whalley, and by her had two sons and three daughters. Abraham Townley's name figures prominently in the parish registers of Ribchester. He was frequently Churchwarden, and was a member of the "twenty four." He was also a governor of Blackburn Grammar School, being elected in 1690. "In 1694," says Mr. Abram, "he was a juror on the celebrated trial of the Jacobite gentry for treason at Manchester." Abram Townley died in 1701, aged 66.

Henry Townley, eldest son of Abraham Townley, married Anne, daughter of Mr. Thomas Wilson, of Giggleswick. He died before 1731, leaving three daughters, between whom the property was divided. His widow married Mr. John Nock, of Preston, the builder of "Nock's Folly," in Narsh lane.

On the partition of the Townley property in 1738, Dutton Hall was settled on Mr. Edward Entwistle, of Ribchester, who had married the eldest daughter of the last of the Townleys, of Dutton. In 1805, Mr. W. Joule purchased the estate, and in 1823 sold it to Mr. James Rothwell, uncle of the Marquis de Rothwell, of Sharples Hall, Bolton, the present owner.

\section{Heynouse, or Hiah House.}

This farm house is situated on the lower side of Longridge Fell. Here it was that the Earl of Derby, the grandfather of the present Earl, Dicky Swarbrick, and the lato Dr. Eccles, with the Cottams, used to meet during the hunting season. The Earl of Derby often

1 . Inc. Lanc. Faunilies.-Antiq. Notes. Laine. Inq.
"Commonly known as the "Yancashire l'lot. 
stayed one or two weeks at the Birks Farm, Thornley, and the stone steps, by which ho mounted his horse, are shown to this day. The louse is quite modern, with the exception of the S.IV. cnd, which is of the date of the sixteenth century. The only stone with a date is one with 1610 in raised figures upon it. Down to a few years ago the house was licensed as the Dog and Partridge Inn.

Roades's of Halghouse (Hey House).

Roades is an old name in this district. Frequently do we come across it in the registers at Ribchester Church. In I309, Juhn Roades, of Rilichester, made a deed of entail of lands and tenements upou John Roades, his son, and the male issue of his body.

"John Roades, gentleman, of Ribehester, orned 'le Halghouse,' 55 acres of land, 2 gardens, and 2 orchards in Ribehester. He also owned 1 garden, 1 orchard, and 30 acres of land, besides certain lands and tenements ul' to the Ribble. He held them of Richard Sherburne, Esq., and they were worth per ann. (elear) 30s. He died at Ribchester, 28th Jan., 1619-20. John, his son, and next heir, was aged 30 years."

In 1696 , a member of this family left the rent of a small farm, as a charity for poor distressed housekeepers of Dilworth, full particulars of which are given in Chapter $T$.

Buckley Hall.

Buckley Hall is situated a little off the high road, from Longridge to Ribchester. It is a massive looking house, with mullioned windows, but its appearance is spoiled by its boing whitewashed. Baines states that it was built by the Sherburnes in 1661. We can, however, find no trace of its former occupants having been of any importance in the district. Just below the houso is Buckley Delph, a once noted slate quarry, now disused. Crossing Cotrley Brook, you find yourself in a perfectly seeluded glade, one of the best spots for a large picnic that can be imagined. Hore I have occasionally seen herons and other ecarce birds.

REV. Mr. HOLDEN.

"(Philin?) Holden, priest, traditionally said to have been slain by the Cromwellian soldiers in the neighbourhood of Longridge Fell, in the XVII. century" (1648).-Salf. Cath. Alm., 1886. 
Father Holden belonged, it is believed, to the family of Holden, near Stonyhurst, a family which, in time of trial and persecution, never swerved from the faith. His Christian name and the late and place of his death are not known; but a well-authenticated tradition says that he was "cut down at the altar" by a party of "Cromwell's soldiers :" and stains of blood are still visible on his vestments. In a cottage on Longridge Fell, which bears the name of "the Martyr's Head," that sacred relic-dry, indeed, but incorrupt, and with the stains of blood still looking fresh - was kept for generations by his pious family. These precious memorials, together with the old oak chest which contains his chalice and other requisites for masses, are now in the hands of Mr. Ralph Holden, of Woodplumpton.-_"Memorials of a few who suffered for the Catholic Faith."

Rev. Fr. Nicholas Santerson.

"Singleton, Nicholas, vere Sanderson, Lancashire, aged 18. Admitted November 14, 1666, and took the oath. After minor orders, ordained sub-deacon and deacon in May, and priest August 3, 1670.

"Nicholas Sanderson was the son of William and Alice Sanderson, and was born at Alston, in Laucashire, about Easter, 1648. His parents were respectable, of the midlde class, and Catholics. He was always a Catholic, and made his humanity studies at St. Omer's College. (Students' Replies.) Several members of this family became Jesuits. Nicholas Sanderson, borm 1692, entered the Society as a lay-brother in 1725, and died at St. Omer's College, September 22, 1761. Nicholas Sanderson, alias Thompson, born 1731, entered the Society 1750, was professed 1768, and died at Alnwick in 1790. He learned his rudiments under Mr. Occleshaigh, in Lancashire, who had been a student at the Jesuits' College in Wigan, which was destroyed by a no-Popery mob on the outbreak of the Orange Revolution in 1688. Robert Sanderson, born in Lancashire in 1715 , entered the Society in 1738, was professed 1756, and died December 2, 1781. Also a John Sanderson, who died at Bath, 1813."-(Foley's "Diary and Pilgrim Book.") Rev. Fr. Setir Eccles, D.D.

"Seth Eccles, D.D., was born in 1800, at Longridge, co. Lancaster, of an ancient yeomanry family which figures in the Recusant Rolls from the earliest periods. In 1811 he was sent to Serlgley Park School, 
in Staffordshire, and from thenee, after a year and a half, proceeded to St. Edmund's College, Old Hall Green, co. Herts. Shortly after the English College at Rome was re-opened under the rectorship of Dr. Gradwell, Mr. Eceles was adnitted a student in 1820. Here he distinguished himself as a medallist among a body of students embracing names identified with the history of Catholicity in England during the first half of this century-Cardinal Wisenan, Arehbishop Errington, Bishops Baggs and Sharples, Dr. Roek, and others. He was ordained priest in 1825, and on presenting himself to Bishop Poynter was appointed to the temporary charge of Weston Underwood, where, in the event, he spent the remaining fifty-eight years of his life.

"When Northampton was elevated to an episcopal see, after the re-establishment of the Hierarchy in 1850, one of the first appointments to Chapter was the pastor of Weston Underrood, and on the death of its first Provost lie was nominated by the Holy See to the vacant office. This was not the first time his name had been brought under the notice of Rome, for when he published his work on 'Justification,' the honorary degree of D.D. was conferred upon him on the recommendation of Bishop Amhurst.

"At the age of 71 he relinuluished the pastoral charge, and two-anda-half years before his death he became so feeble that he was unable to rise from his bed. He died on July 10, 1884, aged 84 .

"Weston Underwood, Newport Paguell, eo. Bueks, was formerly a chaplainey to the family of Throekmorton."-(Gillow's Biblio. Dict., vol ii.)

\section{ㄲำ}

Robert Dewhirst. = Katherine, dau. Sir Richard

I Houghton, of Houghton.

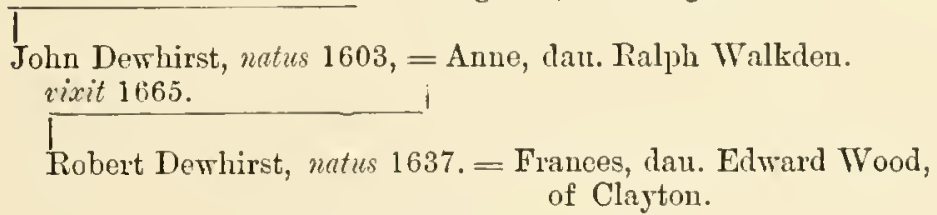

(Had issue one daughter.) 


\section{CHAPTER VII.-RIBCHESTER.}

No "history" written-Leland-Or. Stukeley-Foman remains-Recent discoverjes : Account by the Rev. Jon. Shortt-Philology - Old charters - Lords of the ManorRivenles by the Ribble-Landowners-Manufactures-Crosses- "Old John Rawcliffe"-Old houses-" "Atticus" on the White Bull-- Workhouse: A case for inquiry-Parish Church : 1535-1650-Mr. Harley-Particnlars of living-Stydd Church : Font-13ishop Petre Outdoor Service-List of Riectors: Incorrect list by Baines and Whittaker-Correct list -Rev. G. Wollfyt-Rev. W. Ingham-Rev. George Ogden-liev. John Heber-Rev, John Griftith-Tiev. John AtkinsonRev. B. T. Haslewood-Rev. F. F. Perrin-Rev. F. J. Dickson-"Aggrieved Parishioners of liibchester"-The "twenty-four"- Extracts from registers: Burials in 1690-Cost of entertaining ministers-Price of wine, 1770-Surplice feesHichaelmas dues-Briefs-Foxes and "Noapes"-Strdd Catholic Church-List of Priests-Canon Rimmer-Rev. Fr. 'T. Martin-Almshouses-Bailey chapel : Vandalism-liver Ribhle: "Unfit for trading"-Census retnrns-Agricultural statistics.

Although, strauge to say, no history of Ribchester has yet been written, its antiquities havo beeu fully treated by such historians as Baines and Whittaker, aud a host of other writers.

Leland describes Ribchester as being "a poore thiug" in his day. liut be goes on to say "it hath beene an auncien towne. Great squarid stoues, voults, and antique coynes be founde ther; and ther is a place wher that the people fable that the Jues had a temple." That profound antiquary, Camden, visited Ribchester in Queen Elizabeth's times, and has left an interesting account of his visit to the village. He says that at Salesbury Hall, the seat of the ancient and noble family of the Talbots, he found the pedestal of a pillar with the inscription-" Deo Marti et Victorise D.D. A.V.G.G et C.C. N.N."

In $1725 \mathrm{Dr}$. Stukely made a survey of the ancient city, and gave the following account of what he saw: "The Ribblo is very broad in this place, rapid and sonorous, and, what is much to be lamented, runs over innumerable Roman autiquities, fer in this long tract of timo, it has eaten amay a third part of the city." He estimates that the city occupied a space of 9 to 10 acres within its walls.

So many rich discoveries have been made at Ribchester as to justify Camden's quotation of this "hobbling rlyme of the inhabitants"-

It is written upon a wall in Rome

Ribchester was as rich as any town in Christendome.

The generally accopted Rcman name of Ribchester is Brematoriacum. The following list of the most important remains discovered at Ribchester will give some idea of its original size aud impertance- 
An Altar dedicated to Mars and Victory.

The Foundations of a Temple, erected about A.D. 214, and probably dedicated to Minerva.

Two fine Altars, dedicated to Apollo and the Mother Goddesses.

A small gold cup.

An Altar erected in honour of the Emperor Caracalla.

Helmet, etc., now in Townley collection.

Remains of a Roman bath.

Numerous gold coins bearing the imprints of Vespasian, Trajan, Faustina, Mark Antony, Domitian, and Constantine. Silver and bronze coins of the reigns of Hadrian, Septimus Severus, and Augustus Coesar.

Rev. Jon. Shortt, B.A., Vicar of Hoghton, has most kindly furnished me with the following account of his recent excavations at Ribchester :-

"The most important discovery just made is that of the gate laid open to view, in addition to the ascertainment of the precise size of the camp at Ribchester. It was a square, or very neally a square, of 619 feet; and one of its gates lay in the north-east angle, just in a line with 'Stoneygate-lane,' a street in the village, whose namo betokens Roman origin. A part of this gate was found in situ. It is now a solid beam of oak-not, however, entire. Some of tho planks which led across the ditch have also been discovered. They likewise are of oak: and so are a series of split beams found abutting on the vallum or earth-rampart.

"These were found in two excavations made on the western side. In two others on the northern side they were absent; but on arriving at the north-eastern angle (which we may ubserve, in passing, is rounded), they reappeared in force. They were not, however, as before, at right angles to the rampart, but forming an obtuse angle with it; and were placed above large oak sleejers. It is a curious sight to notice below so much earth a regular platform of oak shingles carefully laid. So far as the writer knows, this is a novel feature in a Roman camp. It is thought to have served the purpose of solidifying the ground close to the rampart. All over the camp enclosure the subsoil is gravel. 
Upon this has been placed a foot of alluvial clay; then the oak shingles, and upon them three feet of clay. Several of these shingles are at Cross Street. ${ }^{1} \quad$ A large quern in a perfect condition and several fragments of similar hand-mills have also been obtained. As usual in the case of old settlements, quantities of fragments of pottery have been met with. It was by means of such that it was discovered that no fewer than seven cities of Troy had existed, one built above the ruins of the other. Likewise, several cities occupied in succession the site of Jerusalen. Some of our Ribchester fragments are of that ware called 'Samian,' the secret of making which has been lost. The most skilful potter of the present day, after many trials, confesses with regret his inability to reproduce its peculiar 'glaze.' Many portions of amphoræe are among the remains, as is also an enigmatical hollow earthenware screw. The riddle has been solved by comparison with a Roman vase found at Colchester. This bears the same screw ornamentation. Evidently the object from Ribchester is a portion of a similar vase, though smaller, which has lost its mouth and base. A sole of a shoe, charged with nails, is so modern in appearance that, though found at a depth of $9 \mathrm{ft}$., it seems ludicrous to assign to it a high antiquity. An iron bit or spike, a brass ring, and a peculiar article of brass and iron, as yet unexplained, are amongst the trouraille. The few Roman coins found are unfortunately so much corroded as to be almost undecipherable; but we may venture to hazard an opinion that one found in the actual earth-work was of the Roman Emperor Nerva, and struck in the last year of his reign, thet is, A.D. 98 . So that if it was lost at the time the vallum was being constructed, the camp cannot have been due to Agricola, as has been supposed; but would have arisen in the time of Hadriau-the great Emperor, who caused the erection of that vast entrenched camp stretching from the Solway to the Tyne, known as the 'Roman wall.' It descrves a very different title. It slould be styled a liuge fortress: by no means built to keep out a barbarian tribe, bnt to maintain a resistless grasp upou two kiudred nations. Nor does any Roman work in our island give, when properly studied, such au idea of the 'far-reaching greatness' of that 
people, whose might has imprinted on the human brain a permanent religious awe. The Ribchester camp was but a single link in that rast chain that fettered Britain for three centuries."

I may add that the cost of the excavations has been in the main defrayed by Mr. Shortt, curator of the Cross Street Museum. "He has been pecuniarly assisted by the proprietors of the Merald to the extent of one-sixth of the expense, which has amounted to $£ 30$. Originally suggested to and urged upon Mr. Shortt by the late Mr. Thompson Watkin, the writer of "Roman Lancashire," the undertaking was persevered in, noswithstanding the loss of counsel and advice sustained by his death. A member of the nation in which he took so profound an interest would think that such conduct rould be acceptable to the shade of the departed historian."

After the departure of the Romans (says Baines), the city of Ribchester began to decline; the Saxons, it is probable, found it in decay; and all that is said of it in the Domesday Survey is that Rebelcastre is in the Inndred of Amouuderness, among the sixteen villages depeudent upon Preston, and contaius two carucates of land.

After the Conquest it is probable that the ancient city regained some of its former cousequence, but its final overthrow was effected by the Scotch invaders, under Brnce, in 1323, when, like Preston, it was burned to the ground. ${ }^{2}$

In 1258, Edmund de Lacyo was Lord of the Manor.

"In 1292, Rybelchestr" occurs as one of the places in which the Prior of St. John of Jerusalem claimed to exercise certain feudal privileges."-Whitt. Whalley, II., 460.

"Among the charters found atPontefract Castle, in 1325, was one de Noite de Ribblescestre, by which Robert de Lacy demised to Robert,

11r. Shortt, whom it is my great privilege to call my friend, has made a suggestion which, had time jermitted, I should have been only too glad to have adopterl. The suggestion was that a collection should be made of all the lioman coins, etc., in the possession of private individuals, MIr. Shortt undertaking to write a deseription of them. May I venture to express the hope that as many rentlemen as possible will fall in with the idea, so that Mr. Shortt's account may appear in the "History of Ribehester?"

2 ". The second volume of 'The Lanca. shire Legends,' published by Mr. Landreth, of Wigan, is said to contain a tale entitled "The Earthquake of Ribchester." "- ("Palatine Note Book," June, 1883.) 
son of Henry, the mediety of Ribblecestre, to be held in free thanage, rent 7s. a year, "Salva eidem Roberto et heredibus suis donacione ecelesie ejusdem ville et foreste de ecrvo et bissa et apro et loga.' "-Whitt. Whalley, II., 460 .

It is perhaps scarcely necessary for me to give the obvious origin of this name-Ribchester. Anciently the word was spelt-Rybelchestr', i.e., the eastrum (the camp) on the Ribble. The various ways of spelling the word I have been able to find are:-Rebelcastre, Ribbecestria, Ribbechastre, Ribbechastria, Ribbechestr', Ribbelcestre, Ribbelcestria, Ribbilcestre, Ribbilchaster, Ribblecestre, Ribblescestre, Ribcestria, Ribelcester, Ribelcestre, Ribelchester, Riblecestre, Ribelchastria, Ribylchester, Robbylchester, Rybbelcestre, Rybbelchestre, Rybcestria.

Stydd, or Stidd, is spelt Stede, Stend, Steed, Steede, Steyde,Sted, Stydd.-A.S. Stede, statio-a homestead. ${ }^{2}$

The various ways of spelling Hothersall are:-Hadreskall, Humdreshall, Hedreshall, Hudersall, Hudersal, Hodiersale, Hethersall, Huddersall, Hadersale, Hoderhall, Hoderisall, Hodersale, Hodersall, Hodrehale, Hodresal, Hodresall, Hodreshale, Hodrishall, Hordishall, Hudrleshale, Huderishale, Hudersale, Hudreshale, Hudreshall, Huthersall.

The derivation of Hothersall is not clear except in the suffix"sall;" A.S., sall or hall, a stone house. Probably the prefix is the name of the founder of the township. Hadreshall is the earliest known way of spelling Hothersall.

"In August, 1230, Walter Mutun and Amab'l, his wife, gave half a mark for a writ for a novel disseisin, 'versus Swanum de Muddleshale de ten' in Ribbecestr.'

"Robert de Hodreshale holds two oxgangs of land in Hodreshale, in socage, paying yearly at the four terms five shillings, aud rolief, etc."-Survey 1320-46.

"Walter Motun gave the Monks of Stanlawe part of his lands in Riblccestre, 'Scil. Hullileye a vin lapidosn,' on the east, to Goderich-

${ }^{1}$ Dr. Mirsh. 
eleyclogh in the wost, 'et a proximo sicho' on the north, to the oak 'cruee signatum' on the south, and three acres of wood to assart 'inter Lavedileye ct Godericheclogh.' "-(Whit. Whalley, II., 460.)

"In time of John of Gaunt, William de Dutton grants lauds to William Moton and others. In 3 Edw. III. (1329), Ralph de Clayton holds lands and tenements. In 1373, H. de Clayton re-grants the Manor of Dutton to Richard de Townley, in whose family it remaiued until the death of Henry Tornley, about the middle of the eighteenth century."

In 1337, Dr. Whittaker says, Henry de Cliderliow was Lord of the Manor of Ribchester.

"In 1353, the Motons were Lords of Ribchester. By a deed, without date, William, son of Walter Mutnn, of Ribelcestre, confirms to God and St. Mary, and to the hospital of St. Saviour under Langrig, and to the master and bretheren there serving God, all the land which Walter, his father, gave to tho hospital in poor and perpetual alms in the town of Ribelcestre. The deed is signed by Adam de Blakeburn, Sir John, his son, William de Samlesbury, Richard de Alveton, Adam de Horton, Thomas de Hunderesall, and others." - (Whitt. Whalley, II., 468.)

Hen. IV., 1406-7.

"Katharine, wife of William Linehalls, lady of the Manor of Ribchester, founded a charity in tho Chantry, and vested certain trust lauds, "Cuidam Capellano divina quotidie celebraturo in quadam capelle. constructa in parte borcali ecclesia de Ribehester, pro salute Regis Henrici ct Ricardi Hoghton, mititis, patre et matre, ete.," -(Whitt. Whalley, II., 460.)

In 1447, Richard de Hoghton was Lord of the Manor, in whose family it remained until 1594., when Sir Richard Sherburne became Lord of the Manor. Then it passed into the hands of the Duchess of Norfolk, and Cardinal Weld, by the latter of whom it was sold to the late Mr. Fenton, whose son, Janes Fenton, Esq.. J.P., Dutton Manor, is now the Lord of the Manor.

Mr. W. Dobson says:- "There is little in the aspect of the village of Ribchester to arrest the attention of the visitor. The Ribble flows by it; but though there are some oxquisite patches of river scenery 
both above and below Ribchester, at the place itself the stream is somewhat tame. The village is irregularly built, its streets are very quiet. It has, however, the appearance of having seen better days." The village of Ribchester is six miles N.N.W. from Blackburn, and three miles S.S.E. from Longridge. Its situation is remarkably pleasant; and the streams of the Ribble, Calder, and Hodder, refresh with thein waters the valley of Ribblesdale, and enrich the general scenery, which is thus described by Mr. William Dobson in his "Rambles by the Ribble:"-About a mile up the river, cn the south side, is Sale Wheel, ${ }^{1}$ a scene of great beauty. "The gorge through which the river passes," says MIr. Wm. Dobson, "is about forty or fifty yards in length. On each side are large boulders, and around and against these, in times of flood, the water boils and chafes with great fury." Not without reason does $\mathrm{Mr}$. Dobson comprare this view to some of the well-known scenery on the Rhine; and it is strange that this beautiful spot should be so little appreciated by the people in the district. Many a day have I spent with delight in exploring the beautiful Ribble in its course from Ribchester to Mytton.

The leading landowners are Jas. Fenton, Esq., J.P., Duttou Manor, 2,300 acres; Frenicrick Openshaw, Esq., J.P., Hothersall Hall, 1,216 acres; Thos. Rymer, Esq., Cheetham Hill, 377 acres; the Marquess de Rothwell, Sharples Hall, 152 acres; and the late Thos. Whittaker, Esq., J.P., Moon's Mill, 131 acres.

The total acreage of the parish, which includes Dutton, 1,809 acres; Hothersall, 1,033 acres; and Ribchester, 2,093 acres; is 4,935 statute acres. The land is good for grazing purposes.

The chief manufactures carried on in Ribchester aro cotton weaving and rood-turning. There are two cotton factories in Ribchester, one belonging to MLr. John Brindle, and the Co-operative Mill, now in course of crection.

Remnants of old crosses are very numerous in the locality. There is onc at Lovely Hall, Salesbury; another one was found in Ribchester churchyard some years ago; in the garden wall of the White Lion Inn (now a farm house) was a plain stone cross, which was removed some 
years ago by the owner, D. Irviu, Esq., into his own grounds. At Piufold and Dutton Lee are remains also of old crosses; and in Gallow's Lane, Dutton, is another of these mumerous relics.

The Blackburn and West Yorkshire Railmay passes between three and four miles of the village, where, at Wilpshire, there is a station called by the name of the village. A new railway is being projected from Preston to Whal'ey, which will pass close to Ribchester.

There is a fino bridge of three arehes, buitt in 1789 , over the river Ribble, about a mile from the village. Close to the bridge is "The De Tabley Arms Hotel," a famous resort for tourists in the days when it was kept by "old John Rawcliffe and his wife."

An old white house (now pulled down), "opposite the strand in Ribchester," is said "to have been slept in by Cromwell before the battle of Ribblesdale." In Church Street there is an old house with a stone over the doorway bearing the dato 1680 . There are no initial letters on the date-stono, which is, however, decorated with floriated designs. It is now used as a butchen's shop.

The old houses in the neighbourhood are Dutton Hall, Huntington Hall, Buckloy Hall, Cottam Hall, Hothersall Hall, Salesbury Hall, the New Hall, and Osbaldeston Mall. The three last meutioned are not in Ribrhester parish, and so are not noticed in this work. Further reference to the old halls and the old families will be found in Chapter TI.

"Atticus" gives such a piquant description of the chef d'aure of Ribchester art that I must once more quote from his work, to which I am already under such great obligations.

Amongst its chief curiosities is "a white bull-a jewel of a creature all over-which would have graced the hieroglyphical art of Egypt, and cast into the shade the winged animals of Nineveh and all its palaces. When that white bull is wanted no more at Ribchester the British Museum people will give something for it. It is the most decided bull we have yet seen. If Rosa Bonheur ever gets a glimpse of it she will 'die larfin,' as the Yankees would say." I am much afraid that this bull, which stands as the sign of the White Bull Inn, Ribchester, will

${ }^{1}$ Cromwell, however, was probably never at Ribchester. 
long remain in the district, as the good people of the village will never accept the tempting offer of "Atticus," although highly appreciating at the same time his flattering remarks upon their "one work of art."

Two miles from Ribchester is the Ribchester Workhouse, one of the few smaller poorhouses still existing. The building accommodates a number of poor and harmless imbeciles. Built early in the present centnry, the sum of $£ 100$ was expended from Townley's charity, Dilworth, in its erection, and formerly the sum of $\mathfrak{f} 410 \mathrm{~s}$. was paid yearly out of the poor rates as interest. But for some years this interest has not been handed over. It certainly seems to be a matter which deserves some explanation from the authorities.

The Workhouse is rather out of date, and has been condemned by the Local Government Board Inspector; but apparently the country guardians of the poor do not relish the abolition of one of their solitary "happy hunting grounds." Mr. Livesey, the governor, has held that position for a long term of years.

\section{The Parish Church.}

The Church, dedicated to St. Wilfrid, is a rude, irregular pile. The date of its foundation is uncertain. Dr. Whittaker says the present choir is of the age of John (1199), or the earlier part of Henry III. (1216), so that it was probably built about the beginning of the twelfth century.

The earliest entry in the Parish Registers is of the date 1590. On the north side of the Chureh is the Dutton Choir, founded by Sir Richard Hoghton in 1405. In this chapel is a tombstono bearing date 1649. The Hoghton Choir, on the south side, is supposed to be of the age of King John or Henry III. The pulpit bears date "C. H., 1636." The sedilia and piscina in the chancel, a solid block of stone, also in the chancel, with the arms of the Hoghtous and other omblazonments on it, are very interesting.

\footnotetext{
"It should be stated that the sign of the "Bull" is very common in the neighbourhood, a fact due to the manorial rights long possessed by the De Hoghton family, on whose coat of arms
}

it figures.

There is a carved figure of a white bull in Longridge, but its artistic merits are far from equalling those of its rival at Ribchester. 
At the time of the Reformation, the possessions of the chantry, dedicated to the Blessed Virgin Mary, were seized for the King's use. "James Tarleton" was the "priest Incumbent ther of the foundation [1405] of Sir Richard Fonghton Knight ther to celebrate for the sowles of his antecessors. ${ }^{2}$

"The same is at the alter of our lady within the parochial chureh of Rybchestre and the said preist Incumbent doth celebrate accordinglie." There was no plate belonging to the chantry, but a long list is given of "the mansion house, closes, and parcells of land" belonging to it. Some of the names of the tenements may be given: "Stoneyfurlonge," "Atough," "Morchase," "Avergate," "Steyde." The names of some of the tenants are: Jenkyuson, Hayhurst, Talbot, Holte, Baker, and Forrest. The net ineome received by the Inemmbent anonnted to $£ 96 \mathrm{~s}$. $3 \mathrm{~d}$. ., "after paying the reprises, and the houseling people there anounted to $500 . " 1$

It was also stated that there was "lande geren to the fyndinge of a Lampe in the Parish Chureh there but whether the same was geven to hare contynuance for ener we know not; of the yearly value of $V$ s."

I tako the following extracts from the "Status de Blagbornshire":

"Post heec autem crescente fuldium devotione, memeroquo credenticum augmentuto in partibus illis, constructa fuerunt alia tres ecclesia infra Blagborushire; videlicet, ecclesia de Blagborne, ecclesio de Chepyn, et ecclesia de Riblechester, parochia ecclesiurum earundem ab inviccm distincte, et aetis undique limitibus designate, prout in pruesens usque continui, persecerant, et "pued omnes partibus illis imotescunt."

"Malor Ecclesiasticus temp. Hen. IIII.

21; Henry VIII.

"First Fruits Office Returns-I'alores sum 'spccalium $q^{u}$ in Temporalium pertinen' Monasterio Monachoz Alboz de W'hallcy, infire Decanat pred' Johanne Passeleive Abbe ib'm.

Rybchester.

Redditus unius pareclle terr' itidem pom - - ot. 2s. Od.

${ }^{1}$ Canon Raines- Luncashive Chantries. 


\section{Dutton.}

,

,

2

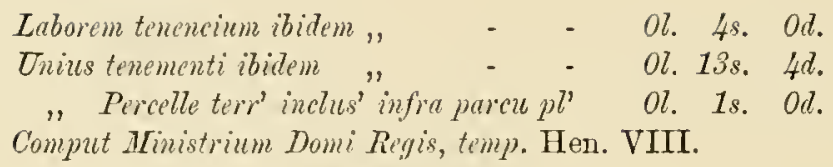

Whalley nuper Monusterizm.

Rybchester, Reddit' assis' - - - - - ol. 2s. 1d.

"The impropriate Rectory and Personage of Ribchester, in the" County of Lancaster, with all the tythes, lands, and hereditaments theremnto belonging, was in the 20th day of June, 1 James [1603], leased by Richard, then Bishop of Chester, unto John Dewhurst, of Dewhurst, in the Connty of Lancaster, gent.; John Sherburne, of the same County, gent.; Henry Heyhurst, sonne and heire apparant of John Heyhurst, of Heyhurst, in Dutton, in the same County, gent.; Hugh Serle, of Chesbanke, within the Townshippe of Ribchester, within the said County, yeoman; Thomas Dudell, of Alston, in the said County, yeoman; and Ralph Ratcliffe, of Dilworth, in the said Connty, yeoman ; excepting one tenement or cottage then in the occupation of the Vicar of Nextros, for the terms of three lives (viz.), the life of the said John Sherbnrne; William Derrhurst, sonne and heire of John Dewhnrst, in the County of Lancaster, yeoman; and Thomas Cottam, sonne and heire of John Cottam, of Heyhouse, also Hayhouse, in Dilworth aforesaid, yeoman, and for the longest lives of them, yielding and payeing to the said Bishopp and his successors the yearly rent of Thirty-nine pounds, sixteene shillings, and sixpence, at the Nativity of John Baptist and the Nativity of Our Lord, by equall portions. And for non-payment of reut after the space of two months (it being lawfully demanded), the Bishopp and his successors to reenter. The Bishopp is to find a Minister there during the tyme at his owne charege. And alsoe, to free the temnants and inhabitants of the said Parrish from all subsidies, fifteenes, tenthes, Synodals, and procurations, and all taxes, lays, impositions, or payments which may any wayes become due hy reason of the said Parsonage or Rectory, or any part thereof; And that the tenant shall have sufficient howsebook,

${ }^{1}$ Ellis's "Monasticon." 
ffirebook, ploughbook, and lodgebook in and upon the premises, for necessary reparation, maintenance, uphoulding, and fenceing thereof. The Tennarts to mayntayne the premisses, chauncell, etc., with hedging, fenceing, and ditching the same, and so to leave it at the end of the said tearme, and in the meane tyme to cutt downe uo greate timber trees without lycence of the said Bishopp or his successors, exeept for necessaly reparations of the premisses or some part thereof.

"The Impropriate Rectory is now held by Richard Sherburne, of Stonyhurst, in the County of Lancaster, Esq., who is Lurd of the Manuor; there is one life in being only, viz., Mr. Jolın Sherburne, aged seaventy-three yeares. There is, belonging to the Parsonage, a ffaire Parsonage house built with bricke, and one barne, about five bayes in good repair; there was another barne of about eight bayes, which is blowne downe about three years agoe, and not yet built againe, most of the tymber lost.

"There belongeth to the Personage, about one hundred acres of land, aud about twenty acres of it is woodland, in which both tymber and underwood is much destroyed since these late troubles. The gleabe and house have beene worth in the best tymes sixty pounds per annum. There is alsoe three Tenements and twelve Cottages more which belong to the said Personage and Rectory.

"There is belonging to the parrish ffire Townships, viz., Ribchester, Dilworth, Howston ${ }^{1}$ [Alston], Veeresee, ${ }^{2}$ and Dutton; the tythes of the said parish have beene estimated worth Two hundred and fifty pound per annum, besides the gleabe and Tennants' rents, but they are now held by the Teunants dureing the lease.

"The Minister hath power to ffish, soe far as the gleabe land goeth, but there is not any benefit made of it. ${ }^{3}$

"The Bishepp hath almays allowed twenty marks per anuum towards a Ministery ont of the rent; they are at presont without auy Minister, only hire soe often as they can, and pay the Minister sc farre as the

${ }^{1}$ This is one of the first variations of the modern way of spelling Alston that

I have been able to find.

${ }^{2}$ Hothersall.

\footnotetext{
${ }^{2}$ How was this? There was, let us hope, wo pollntion in the "good old times" of the libble, as there is unfor. tunately in these civilised days.
} 
twenty marks will goe, and make up the rent ${ }^{3}$ of theire owne purses. There was one Mr. Harley, Curate ${ }^{2}$ there, but was put out by the Committee of Divines in Lancashire for his insufficiency, and being scandalous in his life and conversation."

The Particulars of the Gleabes and of the Tenements and Cottages as followeth upon the Racke.

The herbage of the woodland to be worth per anmum ...

One pasture of Gleabe, called Cow Close, consisting of eight acres,

Another pasture, called greate Carr, consisting of ${ }^{2}$ tenue acress, valued per aun. ... Cons,

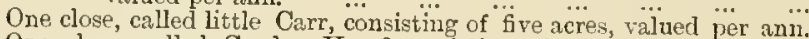

One close, called Curden Hey, ${ }^{3}$ consisting of twelve acres, valued

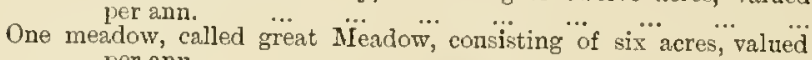
per ann.

One close, called the Dogbotham, consisting of seaven acres, valued per ann.

One close, called Horse Rome, consisting of three acres, valued per

One close, called $\dddot{P}$ aratt, consisting of foure acres, valued per ann. $\ldots$

\& s. d. $04: 00: 00$

$03: 06: 08$

$06: 00: 00$

$02: 13: 04$

$06: 10: 00$

$07: 10: 00$

$05: 10: 00$

$03: 05: 00$

$02: 10 \div 00$

$£ 41: 05: 00$ One other close, called Marybone Close, conteyning foure acres, valued
per ann.

The waste about the Personage, estimated to be above seaven acres,

valued per ann.
One close, called Witridding, by estimation foure acres, valued per

Two closes, called Great Eyes and ${ }^{2}$ Litle Eyes, consisting of nyme acres, valued at per ann. ... ... ...

$$
\begin{array}{r}
03: 00: 00 \\
04: 10: 00 \\
04: 00: 00 \\
07: 15: 00 \\
\hline 19: 05: 00 \\
41: 05: 00
\end{array}
$$

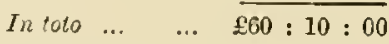

${ }^{1}$ Rest ?

2Mr. Harley, Curate, i.e., of the chapel of ease at Longridge. Mr. C. Hindle was not deposed until 1650 .

Most of the writers on Tibchester cunsider that Mr. Harley is meant for Mr. Hindle, or Hindley. I do not wish to be hypercritical, but still I venture to think that the name is correctly given, and that it refers to $\mathrm{Mr}$. Harley or Hartley, who had been Curate at Long. ridge.

In the first place the Commissioners of the parochial surveys, who made their report in 1650, state that "Mr.
Christopher Hindley was the present Incumbent, but lately suspended," etc. Whereas, in the report of the survey, taken on account of the Bishop, MIr. Harley was called Curate. So particular were the Surveyors that $I$ do not think it likely they would be guilty of such misdescription.

In the Register of Church Livings (1654?), Lansdowne MS., "Christopher Hindley lately suspended by the Pro. vinciall Assembly," is stated to be the

"Incumbent."

"Dale Hey?

-The Parsonace. 
One Tenement in the occupation of John Seecle, by estimation eleaven acres, and he payeth per ann.... $\quad \ldots \quad \ldots \quad \ldots \quad \ldots \quad \ldots \quad \ldots \quad \ldots$

One other Tenement, in the occupation of Edward Seede, estimated ahout eleaven acres, payeing per ann. $\quad \ldots \quad \ldots \quad \ldots \quad \ldots \quad \ldots$

One 'lenement, called Cutber Tenement, in the ocenpation of Elizabeth Cottam, estimatel about eleaven acres per ann. ...

Tient per anm. Rack rent.

$00: 16: 04 \quad 06: 13: 04$

$00: 16: 04 \quad 06: 13: 04$

$00: 16: 04 \quad 06: 13: 04$

f20:00:00

Cottages.

Richard Heyhurst, for Viccaridge ground where the Viearage house stood, per ann. ... .. Fdmund Wood, one Cottage, payeing per ann. ... $00: 01: 00$ $00: 02: 00$ John Berliffe de Francis Green, one cottage ${ }^{1} \ldots \quad \ldots \quad 00: 09: 04 \quad 01: 00: 00$

Then follow eottages tenanted by Edward Heyhurst, Thomas Duehurst, Pereival Duehurst, Richard Heyhurst, Thomas Boulton, Richard Cowell, Mrs. Brooke, Arthur Sowerbutts, Jaseph Hanson, William Ribchester, Richard Norerosse, George Reade, James Reade, Robert Myehell, Jeffrey Sharples, who paid among them $\& 104 \mathrm{~s}$. 4 d., making the tatal into $£ 1213 \mathrm{~s}$. Ad., the amount received from cottage property. "All the cottages have some garden, orchard, or small parcell of ground belonging to them ; ${ }^{2}$ these pay no Herriots to the Lord but the rents at Midsomer and Christmas.

The Bishopp presents the Vicar, and hath alwaies allowed hirn as is before mentioned.

$$
\text { Totall of the Gleabe } \quad \ldots \quad \ldots \quad \ldots \quad \ldots \quad \text {... } \quad 93: 03: 04
$$

The Tymber that belongeth to the Personage of Tilsehester, now growing in Carrewood.

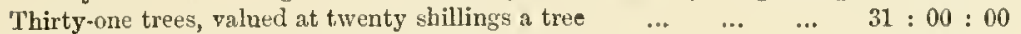

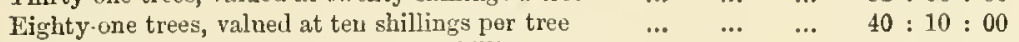
Thirty-seaven trees, valued at seaven shillings per tree ... $\quad \ldots \quad \ldots \quad$ 12:19:00

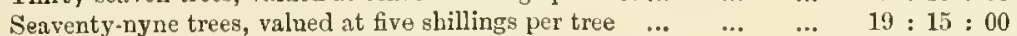

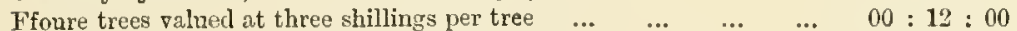

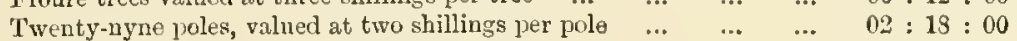

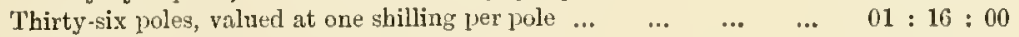

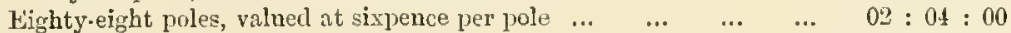
$£ 111: 14: 00$

The Personage and Tennants houses, are to have tymber for their repair ont of the aforesaid wood.

This Survey having bin retnrued about three years, and the life then seaventy-three years of agre,

Query, whether now alive."

1 Francis Green Nook--Ord. Map.

$2 \mathrm{~A}$ wise and healthy arrangement, too often neglected even in rillages like Tibchester.
:This note by the Surveyor is but one of many instances of the business-like way in which they did their work. 
The Rent of Thirty-nyne pound, Sixteen Shillings, and Sixpence

Is apportioned :- $\quad £$ s. d.

To be sould with the lands $\quad \ldots \quad \ldots \quad \ldots \quad 10: 16: 06$

To remayne upon the tythes $\ldots \quad \ldots \quad \ldots \quad$ 29:00:00

$$
\text { In toto... } \quad \ldots \quad \ldots \quad 39: 16: 06
$$

Stydd Citurcit.

Will WeBB, 1650, Dec. 11.

About half-a-mile from Ribchester is the ancient " Mospitale sub Langrig," known as the Chapel of Stydd or Stidd, dedicated to God and our Holy Saviour. This Chapel is undoubtedly the oldest in Lancashire; "the windows are narrow and lancet-shaped, the arches of two doors, though rather pointed, enriched with Saxon ornaments; the doorway is a good specimen of Anglo-Norman architecture of late date, and is a pure and pleasing specimen of that style. The whole building is finished in that mixture of styles which took place in the reign of Stephen (1135)."

The font is a curious octagonal ressel of dark durable grit-stone, adorned with rudely carved devices, and with the letters I.H.S. Immediately before the altar lies, under a slab of beautiful Carrara marble, the remains of the Catholic Bishop Petre, of Armorica, who lived and died at Showley. His titles and honours are thus described:

" Hic juect illustris et Rev'dus dmns. D. Franciscus Petre de Fithlars, ex inclyta ct vetusta prosapia, in comitatu Essexia, Episcopus Aimoriensis et Tic. Apostol. in Districtu Septent. Quem riginti quatuor annos beneficiontiis et apostolicis virtutibus fovit et arnarit, tum plenus dierum. bonorumque operum, premiseis Ifultis Elecmosynis, obiit in Dno. Anno aet. suce 7xxiv, die xxiv Decembris anno DIDCCLXXF.-R.T.P."

The living of Stydd is enjoyed along with the rectory of Ribchester. From the Reformation down to the year 1829, service was held here only twice a year, but, since the late Mr. Haslewood became Rector service has been held once a month. The present Rector in addition holds service at Stydd once on Sundays during the summer months. These services arc generally very well attended.

1The following mutry in the Parish Fiegister records Bishop Futre's burial : “ 1775 . Dec. $2 i$
"Francis Peter, Esq., Showley, a Romish Lis'p." 


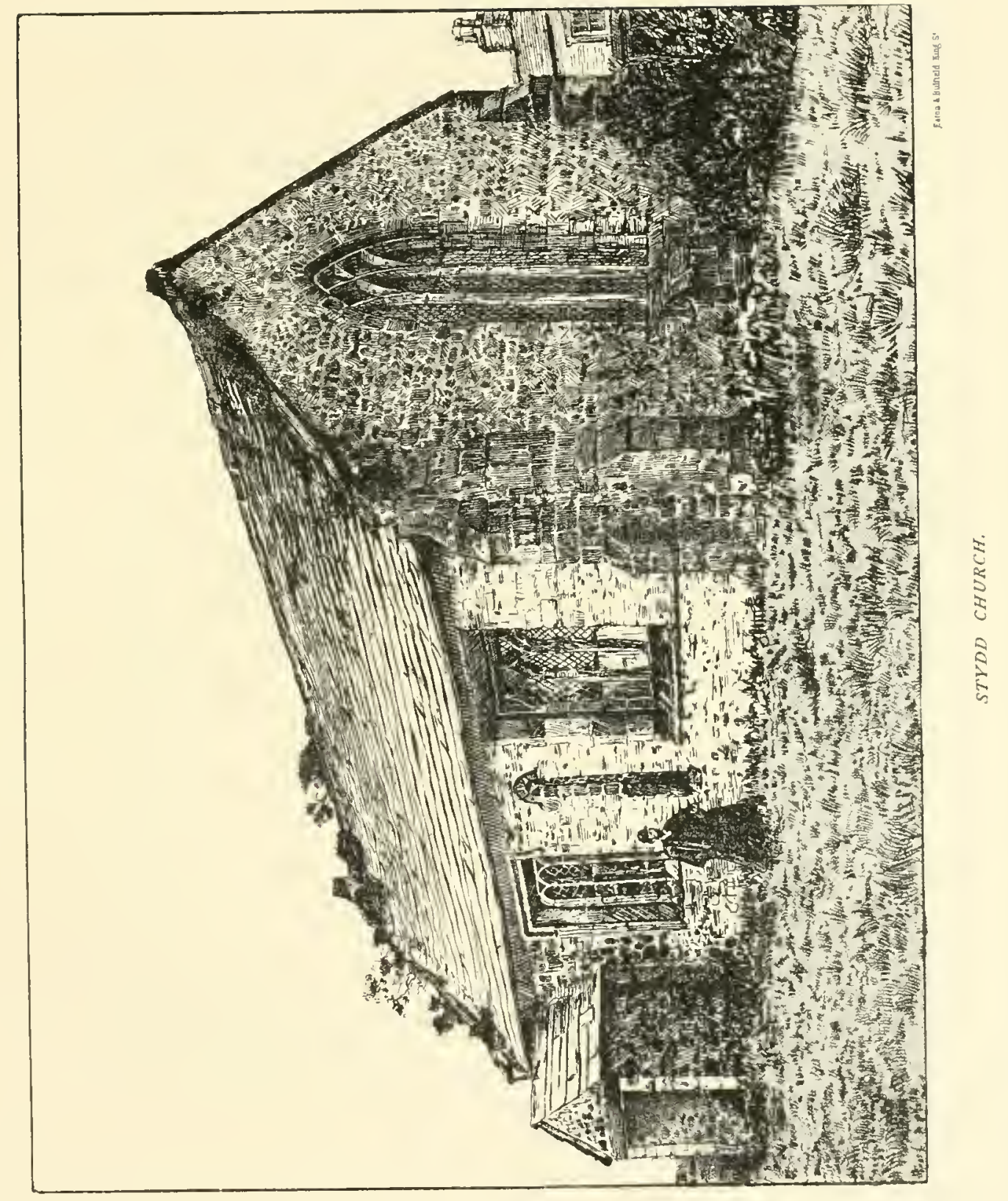




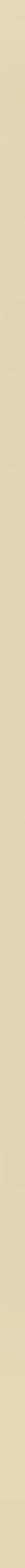


"And the presenters [at the Inquisition taken at Blackburn, 25 June, 1650] further say, "that Steed is A Parishe wherein is one Parishe Chureh called Steed Chureh, being a donativo from the Abbott of Cockersand, but now from MIr. Holt, of Grislehurst, Lord of the Manor of Steed, worth in the whole six pounds thirteen shillings and foure pence per ann. paid hitherto to the Minister att Ribchester, Beinge Accompted Parson at Steel, there being onely Senventeene Families within this Parish, the same beinge Three quarters of A Myle distant from the Parish Church of Rihcliester."

The rarity of the sight must be my excuse for giving an account of an outdoor service held at Stydd Church about two years ago. The account was written by a lady-relation of mine; and being present on the occasion, I can vcuch for the accuracy of her eloquent description. "Hearing that there was to be a service at the venerable Church of Stydd on Sunday afternoon, we availed ourselves of the opportunity of once more seeing the interesting old fabric. Upon reaching Ribchester we were just in time to see the seholars walling in procession from the School with their newly-appointed Rector (Mr. Dickson), at their head. Pretty indeed was the sight of the scholars, clad in clean, light garments, and carrying variously-coloured parasols, walling along the old winding road and through the green fields leading to the Church, which claims to be above $700^{\circ}$ years old, and in which tradition affirms the Apostle Panl preached. The day was lovely, and as a large congregation had assembled, which could not without discomfort have been accommodated within the walls of the ancient structure, the Rector wisely decided to hold service in the Churchyard. It was a beautitul scene, not only striling by reason of its novelty, but also touching in its simplicity. At the east end stood the white-robed clergyman, with the sun shining full upon his bare head; around him were benches quickly filled by the people, while many sat down upon the grass, reminding one of the scene when

\footnotetext{
${ }^{1}$ Lanc. Church Surveys.

${ }^{8}$ No visitor to this interesting Church can view calmly the names of nobodies scribbled all over the sacred edifice. Not even the pulpit has escaped the
}

wantons, How is it that trippers cannot visit any old place without leaving behind them their autographs either cut into the woodwork, or rudely written on the walls? 
Jesus ministered both physical and spiritual food to the five thousand, who sat down because there was much grass in the place. Everythiug seemed to be in harmony with the situation. For miles around there was lovely scenery, the trees waving on the banks of the Ribble, the hills, the valley, and the birds of the air all seemed to add their share of praise and to magnify the Lord."

The living of the Rectory of Ribehester with the Vicarage of Stydd is returned at $£ 300$ with a residence. The present value of the tithes is $£ 198$ 10s. The Bishop of Manchester is patron of the living. The number of sittings is: Ribehester 610, of which 366 are free; Stydd 250 , all of which are free. ${ }^{2}$

\section{List of Rectors and Vicalis of Ribchester.}

(Acoording to Baines and Whittaker).

(Before 1246) Drogo.-Drowned iu the Ribble.

Oetober $1246 \quad$ Imbertus.

1292 Robert de Pokelington.

(Res. in 1343 Walter de Wodehouse.-Resigned.

Nor. 10,1343 William de Wakefield.

1351 William de Horneby.

Mar. 1, 1364 John de Lincoln.- Resigned.

Feb. 27, 1367 William Bolton.

Nov. 8, 1395 Johu Farmer.-Resigued.

1414 John del More.-Resigned.

April 5, 1419 Richard Coveutre.

Dec. 3, 1419 John Ellysryk.

(Before 1460) Robert Bromlaw.

1476-77 William Talbot.

Augr. 26, 1508 Robert Crombilholmo.-Resigned.

July 31, 1527 William Clayton.-Died.

Dee. 21, 1532 Thomas Thirelby.

1" Ribchester was formerly in the parish of Whalley, but it was separated from the parent stock in Saxon times."
It was also in the hundred of Amounderness down to modern times: it is now in the hundred of Blackburn. 
June 9, 1543 George Wolfytt. -Resigned.

Mar. 9, 1573 H. Norcrosse.

Dec. 17, 1616 R. Learoyde, B.A.-Resigned.

Feb. 5, 1617 Chris. Hyudle. ${ }^{2}$-Ejected.

1699 George Ogden.-Died.

Aug. 3, 1706 Thomas Jolnnson, A.B.-Died.

Feb. 26, 1738 John Heber, A.M.

Aug. 29, 1775 John Griffiths, A.B.-Died.

July 27, 1776 John Atkinson.

July 11, $1798 \quad$ Isaac Relph.

April 23, 18023 James Quartley.-Died.

April 16, 1829 B. T. Haslewood, B.A.

In several works in which reference to Ribchester is made, attention is called to the fact that there liave leen only twelve vicars of Ribchester from the Reformation down to 1876, the date of Mr. Haslerrood's death. Certainly, it would have been a noteworthy thing, and deserving of boing placed on record, only, unfortunately, the statement turns out to be pure fictiou. ${ }^{4}$ Of course, I do not attribute over much blame to Mr. Baines, the historian of Lauchshire, for it would be mauifestly impossible for the writer of such a siupendous work as "The History of Lancashire" to verify all the informatiou lie received. It rould be interesting, however, to know who was $\mathrm{Mr}$. Baines' informant. I venture to hazard the conjecture that he simply copied the list of vicars from Whittaker's "Whalley."

And, therefore, the learned Dr. Whittaker must be held to be guilty of the grievous fault (in an historian) of unreliability. For Dr. Whittaker was very familiar with Ribchester. ${ }^{5}$ To this village he paid many visits, and of its antiquities he largely treats. Did it never occur to lim to look througl the parish registers for the names of the vicars?

\footnotetext{
1 In a note to Baines" "Lancushire," edit. 1870, signed Brooke Herford, is the following: "There is, however, a gap in the list of Vicars, as C. Hindle died in 1657, and it is possible that Ingham's name shonld come in between Hindle and Ogden." - Not only "possible," but "really," as I show.

" "Formerly Incumbent of Chipuing."
}

${ }^{3} 1800$ accol'ding to Whittaker. the additional ministers of Ribches. ter which $I$ have diseovered were, it is true, only curates, but as two of them, at least, were "curates in charge," the above eriticism holds good.

${ }^{6}$ For 12 years, $1509-22$, Dr. Whittaker was Vicar of Whalley. 
That he did examine the registers to a certain extent is clear from his chapter on Ribchester. But, apparently, he never thought it his obvious duty to carefully and closely scrutinise the church records. This is, I fear, only one more additional proof of his carelessness and neglect in collating and verifying his facts. I make these observations -as becomes a humble student in the domain of historical researchwith all due respect and reverence for the learned historian of "Whalley;" but had he examined at all critically the registers of births, marriages, and deaths at Ribchester Church, he would have found the evidence which the present Rector of Ribchester and the writer have been able to place before the reader.

Nor can the editors of the last edition of the " History of Whalley" escape their share of blame by the light of the following paragraph from their preface:- "But in respect to the descent of great properties, and the correction and continuation of the lists of incumbents of the older churches, and the masters of the grammar schools, this edition will be rendered as complete as possible."--Vol. I. xi.

LIST OF VICARS AND "CURATES-IN-CHARGE" OF RIBCHESTER

Since the Reformation (revised and corrected according to the

$$
\text { Registers). }
$$

June 9,1543

George Wollfyt.

Nar. 9, 1573

H. Norcrusse.

Dec. 17,1616

R. Learoyde, B.A.

Feb. 5, 1617

Cliristopher Hindle.

$1651^{3} \quad$ William Ingham.

Oct. 6, 1681 George Ogden.

1706 Thomas Johnson, A.B.

1738 John Heber, A.M.

1750 IV. Ayrton.

1758-60 James Fisher.

1761 Page Godfrey.

1764 Mark Burn.

1765 Myles Atkinson.

1766-67 Edmund Armitstead.

1768 Reginald Heber, LL.B. 


\begin{tabular}{|c|c|c|}
\hline & $\begin{array}{l}1769 \\
1770-75\end{array}$ & $\begin{array}{l}\text { William Hodgson. } \\
\text { W. Barton. }\end{array}$ \\
\hline Aug. 29, & 1775 & Johu Griffith, A.B. \\
\hline July 27 , & 1776 & John Atkinson. \\
\hline & $1776-97$ & Isaac Relph. \\
\hline July 11 , & 1798 & Isaac ReIJh. \\
\hline & 1801 & James Quartley. \\
\hline April 14, & 1829 & Boulby Thomas Haslewood, A.B. \\
\hline & 1876 & Frederick Eugene Perrin, M.A. \\
\hline & 1885 & Francis John Dickson, M.A. \\
\hline
\end{tabular}

The Rev. George Wollfyt, or Wolset, was one of the Kiug's preachers for the County of Lancaster, I. Ed., VI. (1547), and held a lense of the Rectories of Chipping and Ribehester from Bishop Bird. He was then a Protestaut, although in his will he desired "prayers for his soul." "February 1st, 1552-3, George Wulfet, doctor of lawe - to be buryed within the chauncel of Rybchester, yf I dye there er els where in Christen man's buryall-to every one of my godchyldren within Rybchester, Chepen, and Wishawe parishins xiid. to put them in remembrance to praye for my soule. To Alyce Cragge daughter to John Cragge a doughter to my suster Alyce his wife iii li, to be payd by William Wren-to William Cragge brother to the said Alyee iii li to be payd by my brother Jeffrey Wolfet. I wyll my scarlet gowne lyned with blacke damaske and my beste murrey gowne having the sleves and forequarters lyned with tawney sareenet to be praised ${ }^{2}$ and solde and the money to be bestowed on the poore householders-the residue to be dispersed by my excutors in charitable dedes to the pleasure of Almighty God and comfurthe of the poore and indegent people, not meanynge hereby to burden or charge his conscience in suche bestowinge but onlie to commytte the same to his discrecion, aceordinge to such expectation and affiance which I haue in him-my brother Jeffrey Wolfet executor and Robert Patchett and Syr Thomas Thorpe overseers. Proved 7th August 1554, by Mr. Robert Cressie official of the Archdeacou of Notts."-Canon Raines, "Lancashire Chantries."

${ }^{1}$ Appraised, valued. 
REV. W. INGIAM.

Rev. Wm. Ingham was Vicar of Ribchester for 30 yoars, although, as I have said, he is not placed in their list of Vicars by Baines or Whittaker.

The following extract referring to him is taken frem the parish registers :-

"Memorand.-It is ordered this 5th day of April, 1670, by ye Gentlemen and forre and twentye of ye p'rsh of Ribchestr' y'at whenever Mr. Will. Ingham, minister of the sil p'rish

y'at he shall send word by ye churchwarden , bring ten shillings eight pence : to comm'co immediately from this day.

"Witness our hands."

Among the "Institutions" contributed to Antiquwrian Notes is the following:-"Stidd Chapel. William Ingham, Clk., by the Bishop of Chester, 23 Aug., 1661." The date given here should be, I conjecture, 1651. Certainly he was Vicar of Ribchester in the latter year.

REV. GEORGE OGDEN.

Dr. Whittaker makes a most serious error in the date of the Rev. George Ogden's appointment to Ribchester. The Rev. W. Ingham died in 1681, and Mr. Ogden was appointed Vicar in 1681, whereas the historian of Whalley gives the date as 1699 !

Mr. Ogden, who was a Fellow of the Collegiate Church of Manchester, seems to have been most assiduous in improving the temporal affairs of the parish over which he ruled for 25 years. He built the vicarnge at his own cost, gave the communion table at Stydd, and in varions other ways greatly improved the state of the church. $\mathrm{He}$ also took a keen interest in the discovery of Roman romains, as Stukely, who visited Ribchester in 1752, testifies:-_"The late minister of Ribchester, the Rev. Mr. Ogden, collected all the coins, intaglios, and other antiquities, found there in great quantities; but his widow,

'Illegible. Seems to refer to marriages. 
as far as I can learn, disposed of then to Mr. Prescot, of Cliester." For the way in which ho records the various loral events of interest he deserves the utmost credit.

"Memorandum.-That in ye year 1682, I, George Ogden, Vicar of Ribchester, built ye vicarage hous there, at my own charge. Except three pounds odd shillings were contributed towards the same, by some well affected persons. Upon this acconnt Mr. Abraham Townley, of Dutton, gave twenty shillings.

"But since I have writ thus far I have found it for a certain truth $\mathrm{y}^{\mathrm{t}}$ ye said inhabitants of Dutton have for several years together both to ye King and poor overated me in many pounds before I discovered it. I have therefore no reason to thank them for ye above said kindness.-Aug: ye $2^{d} 1701 . "$

"December $y^{\mathrm{e}} 1^{\text {st', }} 1703$.

"Memorandum.-Whis day Mr. Ogden, Vicar of Ribchester, gave ye Communion Table at Stid Church, and caused the long seat in the chancel to be fixt under the South WVindow: and has like wise bestowed a Dapper limen Cloth almost a yard and a half in length, and about $y^{\mathrm{e}}$ same kreadth, lettered in the middle, with these words, This for the holy Sacrament at Stid to be lodged and decently kept in or at ye clarks of Ribchester his hous for ever. Witness our hands."

REV. JOHN IIEBER.

The Rev. John Heber was very little in residence at Ribchester, many of his curates siguing themselves as "ministers," or "curatesin-charge."

REV. JOHN GRIFFITH.

The Rev. John Griffith does not appear to have ever been at Ribchester.

REV. JOHN ATKINSON.

The Rev. John Atkinson was nominally Vicar for 23 years, but the Rev. Isaac Relph (substitute) was Curate (who was appointed Vicar on Mr. Atkinson's death) during the whole period. He was appointed one of the King's preachers for the connty of Lancaster, 25th Nov., 1786. Mr. Atkinson seems to have paid periodical visits to the parish from Walton-le-Dale, of which Church he was Curate, as well as Vicar of 
Ribchester. In the Church at Walton there is a tablet with the folloring inscription:- "To the memory of the Reverend John Atkinson, Vicar of Ribchester and Curate of this Chapel, who died Dec. 15, 1797, aged 51."

REV. B. T. HASLEWOOD, B.A.

The Rev. Bonlby Thomas Haslewood, B.A., was the son of the Rev. Dickens Haslewood, Minor Canon of Durham, and was born at Durham. For some time Mr. Haslewood was Vicar of Bishopwearmouth, being appointed to Ribchester in 1829 . During his long residence at Ribchester-he was Rector for no less than 47 jearsMr. Haslewood worked hard and earnestly, and even in his old age he put to shame many a younger man than himself. Physically, he was a little man, and in later years presented a venerable aspect with his massive head, white hair, and wary beard. "As a preacher," says "Atticus," "he is vigorous-wonderfully active for an old man. When in the pulpit, he holds in one hand a small Bible, and in the other an eye-glass; he starts with a somewhat feeble voice; as he warms up he moves the eye-glass gently, then more rapidly, afterwards looking up at the groinstones in the roof, then puts down both the eye-glass and the Bible, becomes very sincere, shakes himself up and down keenly, gets pathetic; keeps doing this; and finally finishes a sermon which you can't help but admire for its carnestness, power, and clearness." 1 Mr. Haslewood died in 1876, aged 81, deeply deplored by the people among whom he had lived and worked for nearly half a century.

RET. F. E. PERRIN, M.A.

The Rev. Frederick Eugene Perrin, M.A., came to Ribchester in 1876, on the death of the Rev. T. B. Haslewood, who had held the Rectory of Ribchester for the long period of 47 years. Mr. Perrin had been Curate of Whitewell, and Chaplain of Waddington Hospital, near Clitheroe. Нe was a man of untiring activity; was possessed of rare social qualities; and was much estemed for his genial disposition. During the time he was at Ribchester, Mr. Perrin accomplished many

${ }^{1}$ The jresent writer remembers hearing Mr. Haslewood preach, but his memory cannot enable lim to add any. thing to what "Atticus" has said-even if it were possible to supplement such a comprehensive and just criticism. 
urgently needed reforms in the parish. He was instrumental in getting the hiving doubled in value, and also in the restoration of the Church at a large cost. He also obtaiued a graut of $£ 1,500$ from the Ecelesiastical Commissiouers towards the erection of a new rectory. Mr. Perrin was proud of the historical associations of his parish, and had formed a large collection of autiquarian curiosities. As a preacher, Mr. Perrin inclined to the old school of parsons; and his sermons were, we fear, rather dull and prosy. He died rather suddenly on May 10th, 1885, aged 63, and his remains were consigned to the grave amidst the evident lamentations of a large concourse of his friends and parishioners.

REV. F. J. DICISON, M.A.

The present Rector of Ribchester, and Vicar of Stydd, is the Rev. Francis John Dickson, M.A. Mr. Dickson was formerly Tutor of St. Columba's College, near Dublin; Curate of Christ Church, Preston; Rector of Bispham; and was appointed Rector of Ribchester on the death of Mr. Perrin, and is, we believe, the Secretary of the Clerical Association of the Fylde. Already, Mr. Dickson has proved himself to be a model parson for Ribchester. About forty years old, middlesized, and somewhat slenderly built, Mr. Dickson is capable of a great deal of hard work, and does his duty in such a cheerful and kindly way as to endear himself to all who meet him. Wo should saythough quite conscious of the odiousness of comparisons-that Mr. Dickson is one of the best preachers in the district. So quietly, but yet impressively, and with such a wealth of forcible illustration, does he drive home the moral of his sermons; and we are confident that in time the fruit of Mr. Dickson's preaching will be clearly manifested in the raising of the tone of a somewhat neglected and obscure parish.

\section{The Aggrieved Parishioners of Ribchester.}

Under the above heading appears an article in "The Palatine Note Book," Feb., 1883, compiled from the MSS. of Mr. C. T. Talent Bateman, which contains a mass of interesting information. I reproduce the most important portions of the article:-A man named John Warde was chosen, without his consent, by the xxiv. of Ribchester 
at the anuual meeting, at Easter, 1639 , to be the churchwarden for Hothersall. He accordingly sent the following petition to Bishop Gastrell :-

"The petit'on of $\mathrm{J}_{\mathrm{ohn}}$ Warde, of the townshipp of Ribchester in Ribchester P'ish.

"Humbly sheweth

"That whereas your petit'on'r $y^{s}$ and haith been a Resideut Dweller within the towne of Ribchester ever since hee was borne, as also his fforefathers: and being within the hundred of blackburne yor ${ }^{\mathrm{r}}$ petit'ou'r dothe continewall suite and service the Church and the Kings M'tie (still for Ribchester). And yo'r petit'r having a little howse and a little p'cell of laud lying and being in Hothersall in the said p'rishe: some of the xxiiijti of other townshipps of $y^{\mathrm{e}}$ said $p^{\text {'ish }}$ have made Choice of jo'r petit'r to serve as Church warden for that little p'cell of land lying within hothersall : contrary to all custom or any such service being donn by y'or petit's or his fforefathers in two sev'all places: nor any servic' having been donn for the said little p'cell of land these fforty years and abone as yo'r petit'r $y^{s}$ very well able to prove.

"The truthe of your petition's cause for his servic' p'formed for Ribchester on' heartofore and not els whear being considered. And the wrougfull Intent'on of p'te of the said xxiiij to Raise an Unaccustomed service against yor petit'r being thus offered . . . . . that yo'r petiton'r may not be wronged by raiseing a wrongfull custom never soe Inteuded before this tyme and as duty byndeth yo'r petit'r shall duly pray to god ${ }^{1}$ for your Lordshipps : great p'sperety."

[Written in the margin are the following orders.]

"Chester Palace. Ulto Apr. 1639. J wish the p'ishon's would no'i'ate some other man: the rather because $\mathrm{j}$ am informed the Petic'oner is a verie aged and infirme man. Aud if they breake their own custome, their Companie also of 24 . will be soone dissolred.

"Jo. Cestrien."

${ }^{1}$ God. Lordship' (Bishop Gastrell)! 
"Garstange, this 3rd day of May, 1639.

"I wish the inhabitance of Hothersall to elect a Churchwarden, According to my Lord B'pps refferance."

" Wv. Arimtstead."

Apparently the Episcopal monition had noeffect on the "honestxxiv" of Ribchester, for a petition was sent in to the Bishop on June 4, 1639, signed by some of the leading xxiv, and other parishioners, asking for the redress of John Warde's grievance. The signatures are:

Henrie Townley.

Robt. Alston.

Thomas Baley.

John Hayhurst de Ribchestr.

John Hayhurst de Hugh.

Edward Ashe.

John Parlowe.

John Carter.
Thomas Seede.

John Cottam.

Elmonde Watsone.

Thomas Seed.

John Hayhurst.

James Norcrosse.

lioger Sudell.

Jobn Willasey.

Robt. Sowerbutt.

John Ward.

The Bishop of Chester sent two further letters, in which he again admonished "the 24 of $\mathrm{y}^{\mathrm{r}}$ par $^{\mathrm{h}}$." The result of the matter was that the xxiv met and chose a deputy Churchwarlen to act for John Warde.

In 1638 the names of the xxiv were:

IN Ribzhester.

John Ward.

John Cottam.

Thomas Seede de Chesloanke.

John Hayhurst.

Fichard Hayhurst.

In Hothensall.

John Dewhurst.

John Seede.

Richard Huthersall.

'Thomas Boulton.

1The Editor of the "I'alatine Note Book" says that the Hayhursts of Dutton were the relatives of the Rev.

Bradley Hayhurst, minister successively
IN ALsTON.

Roger Seedull.

Iid. Bilshurow.

John Willisce.

Robt. Alston.

Thomas Daniell.

IN DILWORTH.

Lawrence Cottam.

James Norcrosse.

Richard Cottam, senr.

Raphe liadcliffe.

Richard Cottam, jum.

Is DUTTON.

IJohn Hayhurst, junt.

John Barlow.

Joln Hayhurst, senr.

Robt. Sowerbutts.

Thomas Baley.

of $\mathbf{M}$ acclesfield and $\mathbf{I}$ igh, who left all his books, except the Book of Martyrs and his great Pible, to the Parish Church of Ribchester. 
By the great kindness of the Rector of Ribchester, I am enabled to give the following interesting extracts from the registers of Ribchester Church.

Jan. 1667-Payd for Ringing for the joy of the Victory wh. the King had

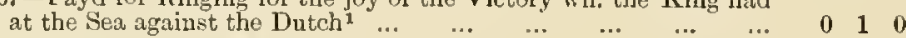

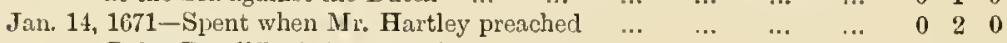
Robt. Ratcliffe, 1740 , one xxiv.

W. Ratcliff, c. w., 1674, Hother.

Edward Rhodes, to serve for widdow Downley for Dilworth, $1675 .^{2}$

Nov, 5, 1675-Spent when great Bible was sent from London $\quad \ldots . \quad \ldots \quad r \begin{array}{llll}0 & 12 & 0\end{array}$

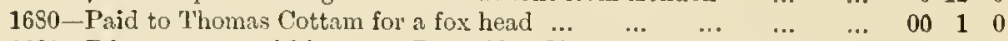

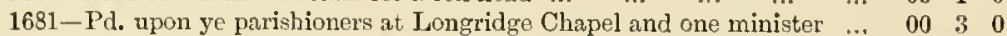

1683-Paid for a warrant from Mr. Brarlyll for tak' np frequent gamsters

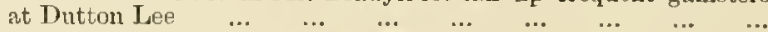

1684-Spent on Mr. Butterworth, and Mr. Coulton ye King's preacher

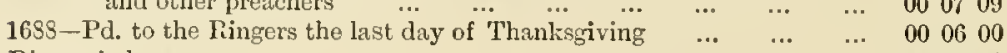
$\begin{array}{lllllllllllll}\text { Ringers' glores } & \ldots & \ldots & \ldots & \ldots & \ldots & \ldots & \ldots & \ldots & \ldots & 00 & 03 & 00\end{array}$ "County of Lancr., 1690.

"Isabell Mitchell, of Dillworth, in ye County of Lanr., widow, maketh oath that she was p'sent by upon Thursday last, the fifth day of this instant, Septemb', and did for the body of Grace Sharples, late of Dillworth aforesaid, widow deceased, wound up or buryed in any shirt, shift, sheet, or shroud, made or mingled with flax, hempt, silke, haire, gould, silver, or in any other stuffe or thing than what was made of sheepe's roole onely, nor was laid or put into any coffin lined or folded $w^{\text {th }}$ any sort of cloath or stuffe, or any other thing whatsoever that is mad' or mingled $w^{\text {te }}$ flax, hempe, silke, haire, goulde, or silver, or any other materiall but sheepe's wool onely.

"Jurat apud Preston, 9 die

$$
\text { "Sept., 16ro. Coram me. }
$$

"Thomas Rigby,

"Witnesses thereof, James Sharples,
"Isabell Mitchell, her $\mathbf{X}$ mark. Thomas Seede."

"Note . . . . . . and that pigg or goose may be takeu in money or kind, whether ye Vicar pleases."

1This was a "victory" by order of Charles II. In reality it was one of the nost liumiliating defeats Lugland crer experienced. Well might Eivelyn call the spectacle of a Dutch fleet anchored at the Nore, "dreadful, and a dishonour never to be wiped ont."

"As Churchwarden. 
"Nov. ye $18\left(94^{2}\right)$.

"Then rec'rl. upon a Brief for $y^{\mathrm{e}}$ poor French Protestants $\mathrm{y}^{\ominus}$ sum of One pounds seuen shillings \& a penuy.

Witnes my hands,

Geo. Ogden, Vicar.

Paid to Dr. Wroe, the warden of Manchester, who paid it to $\mathrm{y}^{\mathrm{e}}$ Bishop."

"A $p^{\text {rl. }}: y^{\mathrm{e}} 10: \mathrm{j} 705$.

"It is ordered and agreed by and with ye gentlemen \& $24:$ of this Parish that $y^{e}$ Churchwardens shall pay to ye Cloarke he behaving him Self as becometh him to do in his place, and also to his Parishioners $y^{e}$ shall make yo 16 s. : \& 2 d. : which is now due to him from ye Parish for keeping $y^{e}$ Register \& Cloke, otc. Yearly ye same In Regrard if he shall not go to gather meat which he Jo. Poole Cloarke doth most Humbly beg you will be pleased to sign ye Same and Alow :

"Signed by us.

"The words above being a reall Request Humbly boging all your approbations by Mo Josiah Poole Claarke in Rib:"

Jan, 19, 1706. - Collected upon ye Breif for Great Farington in ye

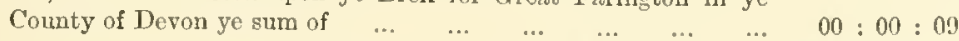

$$
\text { "Mareh } y^{\mathrm{e}} 17^{\mathrm{th}} \text { Day } 1733 .
$$

"Whereas it hath been nsuall to pay one peuny for" every Noape" head killed w'in this Parish, it is now ordered by us that heareeifter there shall not [be] anything Due, as Wituess our hauds

$$
\begin{gathered}
\text { "Tho: Jomrson [Vicar]. } \\
\text { "Roвt. Radcurfe. } \\
\text { "[And others]." }
\end{gathered}
$$$$
\text { "Nov. 22, } 1742 .
$$

"Recd. then from the hands of John Carter the sun of five shillings for painting Two Cherubins upon Two Cannalls on $y^{e}$ singing pew as witness my hand."

\footnotetext{
"1694.

2"A Maupe [or Noape] is a small bird supposed to destroy fruit buds." At Wilmalow, "the crmmon people
}

still speak of Maups as 'titty maup', the titmoure."-W.N. Lane. and Ches. Antiq. Notes. 
June the 11th, 17t3-His Majesty's ${ }^{1}$ Accession to the Throne, spt. 2s. 6d., and Ringer's $2 \mathrm{~s}, 6 \mathrm{~d}$. $\quad \ldots \quad \ldots \quad \ldots \quad \ldots \quad \ldots \quad \ldots \quad \ldots$

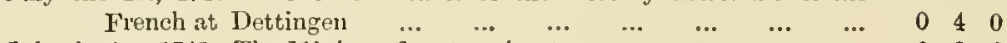

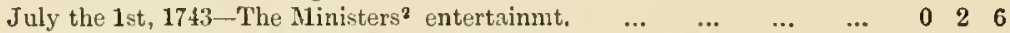

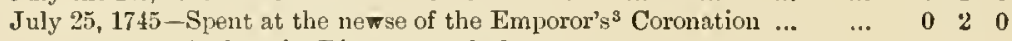

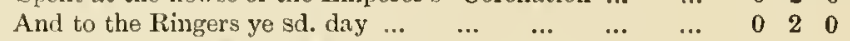

June 16,1745 -To the Ringer's wn. Newse came of the Rebels being sub-

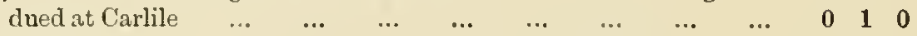

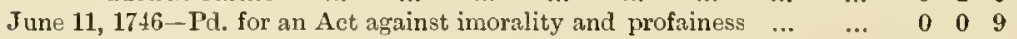

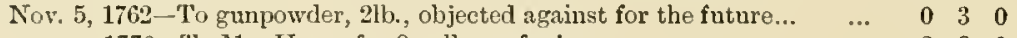

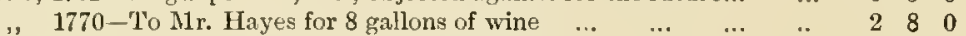
Sorplice Fees.

For every Clandestine Marriage, Six shillings and 8 pence.

For every Clandestine Christening and Churching, one shilling of all persuasions. Michaelmas Does.

For every swam of Bees a penny. For every barren Cow a penny.

"April 10, 1792.

"Agreed on at a Vestry Meeting on Easter Tuesday that the Parish of Ribchester is to build a place of Confinement called a blackhole, the expense of erecting it to be paid by a fifteen, to be collected by the churchwarden and constable of each township, and to be completed immediately, by the 29 of September next if possible.-I. Relph, minister." "4

"Memurandum-That at the meeting of the Four and Trenty on Laster Tuesday, April 5th, 1831, an objection to the Church rate was taken by Mr. Sefton and Mr. Hugh Pickering, as being too hard on the Township of Hothersall. And it was agreed that an enquiry should be made with a view to it being fairly adjusted if any alteration should appear equitable."

"At a meeting held pursuant to ancient custom from time immemorial, in the Vestry loom of the Parish Church, on Easter Tuesday, April 10 th, 1855 , it was resolved that the late Ringers be not re-elected, having of late greatly neglected their dnty as Ringers; and that the churchwardens be authorised to provide as best may be done for the Ringers for Divine Service."

\footnotetext{
${ }^{1}$ Tenrge II. - Annirersary of Corma- $\quad{ }^{3}$ The Emperor Frederick. tion bay.

${ }^{2}$ Rev. Joln lIeber.
} 
"At a meeting of the Four and Trenty, or Aneient Vestry, held pursuant to which duly published, on Friday, September 24, 1869, 'Resolved that the thanks of the Parish are due to Jonathan Openshaw, Esq., for his gift of Land for the enlargement of the Churchyard, and for his help towards making the enelosure."

I may be pardoned for stating here that I have been reluetantly compelled to enrtail mueh uew and interesting information concerning Ribchester. The wealth of the enormous matter I have aequired needs and deserves a volume for it alone. Many necessary comments and notes have also had to be omitted. However, in the near future, I hope to be able to publish a complete "History of Ribchester"-its antiquities and Church reeords.

STYDD CATHOLIC CHURCH.

Stydd Roman Catholic Chapel, dedicated to SS. Peter and Paul, was built in 1789, and was enlarged in 1877. It stands just behind the priest's house. It is a plain, neat building, and will seat about 350 people.

Close to the ehapel is the school, which is attended, on an arerage, by 50 to 60 children.

LISTS OF PRIESTS

Who served on the Mission of Ribchester sinee 1783 .

1783 Rev. Mr. Fisher.

1805 Rev. J. Wagstafie.

Sept. 1844 Rer. Roger Glasbrook.

Mareh 1861 Rev. Henry Browne.

Jany. 1868 Tery Rev. Camon John Rimmer.

Jany. 1872 Rev. Michael Byrne.

July 1880 Rer. Thomas Martin

(present priest).

VERT REV. CANON RIMMER,

Canou Rimmer, priest of Stydd Catholic Chureh from 1868 to 1872, is thus deseribed by "Atticus" :- "A robust, sharp-spirited, middleaged gentleman; looks well, as if this wcrld agreed with him; is straight, tall as a Lifeguardsman, dignified, shiny-headed, serious; is mueh respected, can preacli well, eat well, walk well, and work energetically." 
REV. THOMAS MARTIN.

The preseut priest, the Rev. Thomas Martin, is a venerable-looking old man of fine presence aud genial temperament. He has ler a quiet, useful life, lookiug well after the interests of his flock, by whom he is much respected. Latterly he has suffered much from illness, and is, consequently, getting rather infirm. As a preacher he is plain and practical.

A minute's walk from the church are the alms-houses, established by the Sherburnes, of Stonyhurst, in the seventeenth century. They have a very old-fashioned look about them. In the courtyard is an ancient draw well. The alms-houses are intended for old and infirm Catholic women, who receive a small monthly allowance, upou which they seem to live in a fairly comfortable fashion.

\section{BAYLEY CIIAPEL.}

Just outside the boundary of Ribehester is Bailey Hall, which leserves mention here.

"Bailey, or Bayley Hall, near Stonylurst, was once served by the Fathers of this College. Father Walter Vavasour was there in 1701, and prebably before. He afterwara's went to Preston, where he died on the 10th of April, 1740. He belonged to the Yorkshire family of that name, and was born in 1664. Bailey Hall afterwards passed from the family of Bailey to the Shireburues. It formed part of the ancient nanor of Bailey, Chaighley, and Aighton, aud would now be incorporated in the Stonyhurst aud Ribehester Missious. The manor of Bailey formerly belonged to a family named Cliderhow (Clitheroe). Edward I. granted a licence to Henry de Cliderhow to give lands in mortmain, viz., two messuages in Ribchester and Dutton, forty acres of land, \&e., and six shillings rent, to say Mass daily in St. John Baptist's chapel at Bailey Hall, built by Robert de Cliderhow, late Rector of Wiggan, for the soul of the said Robert and Henry, and of all their aneestors, and the souls of all the faithful departed. Dated at the 'Tower of London, March 16th, 12 Edward I.

"In the 12th Edward III. Henry de Cliderhow granted in perpetuity alms to William de Preston, ehaplain, two messuages in Ribehester 
and Dutton, for Masses to be celeluated yearly in the said chapel of St. John Baptist de Bayley, for the souls (as above). Dated at Bayley, Sunday after St. Martin's Day.

"Some small remains of this ancient chapel still exist, clothed in iry, retired, and but little knomn." -Extract from "Records" of the English Province of the Society of Jesus.

Dr. Whittaker makes the following interesting observations ahout the river Ribble: - "The first mention of Ribhle, after the Roman Bellisama was forgotten, is in the beginning of the eighth century. "Terrae date S. Wilfrido a regibus juxte Ribel fau. id est Hoxmundernes."

- Hist. of Craven, 2nd Edit., p. 19.

The varions ways of spelling the word Ribble are: Rhibellus, Ribel, Rible, Ribbel, Ribbil, Rybel; the origin of the name being (according to $\mathrm{D}_{1}$. Whittaker): Rhir -bel $=$ Head river.

"Ribil," says Leland, "risetl in Ribelsdale, aboute Sallay Abbay, and so to Sawlley. A InI miles beneath Sawlley it receyvith Calder that cummeth by Walley, and after receyvith a nobler water cawlled Oder."

$16 \mathrm{Edw} . \mathrm{IV}$. A warrant was issued to stop the destruction of the "frigt of samon" by unproper nets in the Ribble.

Drayton thus speaks of the Ribble:

Ye maids, the Horn-pipe then, so mincingly that tread. As ye the Egs-pic love, and Apple Cherry-red ; 2

In all your mirth ful songs, and nerry meetings tell,

That Ribbell every way your Erwell doth excell.

Dr. Leigh, in his "Natural "History of Laneashire" (1700), thus describes the Ribble:-

Ribbel, ealled anciently Billesama, has its rise from amonost the mountains in Yorkshire, and runs by Ribchester and Preston; from thence grows wiler, and in the Meole empties itself into the sea. This river affords us plenty of samon, codfish, flounders, turbet, and plaise; but a liver, by reason of its sands, very unfit for trading."

1The "small remains" of this inte. resting fabric were, I am sorry to say, pulled down in 1830 - m act of sacrilese deeply to be deplored - by the late Mr.

Fenton, the Lord of the MInor.

"He that will fish for" a Lancashive man, at any time or tide,

Mrust bait his hook with a good Egg-pie, or an apple with a red sicle."

${ }^{3}$ A remarkable anticipatory confirmation of a general impression prevailing now outside Preston.
In 1555 a M.S. book, entitled "The Bonk of the whole Navye," giving an "account of all Queen's ships, with the tonnage, nvmber of mariners, gunners, and soldiers," was written by Mr. Lawrence Wall, Mryor of Preston, by command of the Earl of Derbs, Lord Lientenant of the County. "On the river near Preston, in Lancashire, called the water of the Ribble," the number of ressels was stated to be $8 .-L a n c . F u n$. Certif. Chetham Society. 
The population returus of the parish of Ribchester during the present century are:-1801, 1,560; $1811,1,901 ; 1821,2,281 ; 1831$, 2,$379 ; 1841,2,290 ; 1851,2,096 ; 1861,1,669 ; 1871,1,706 ; 1881$, 1,673 .

The agricultural returns for 1886 are subjoined:-

Agricultural Statistics.

Number of Statute Acres-*

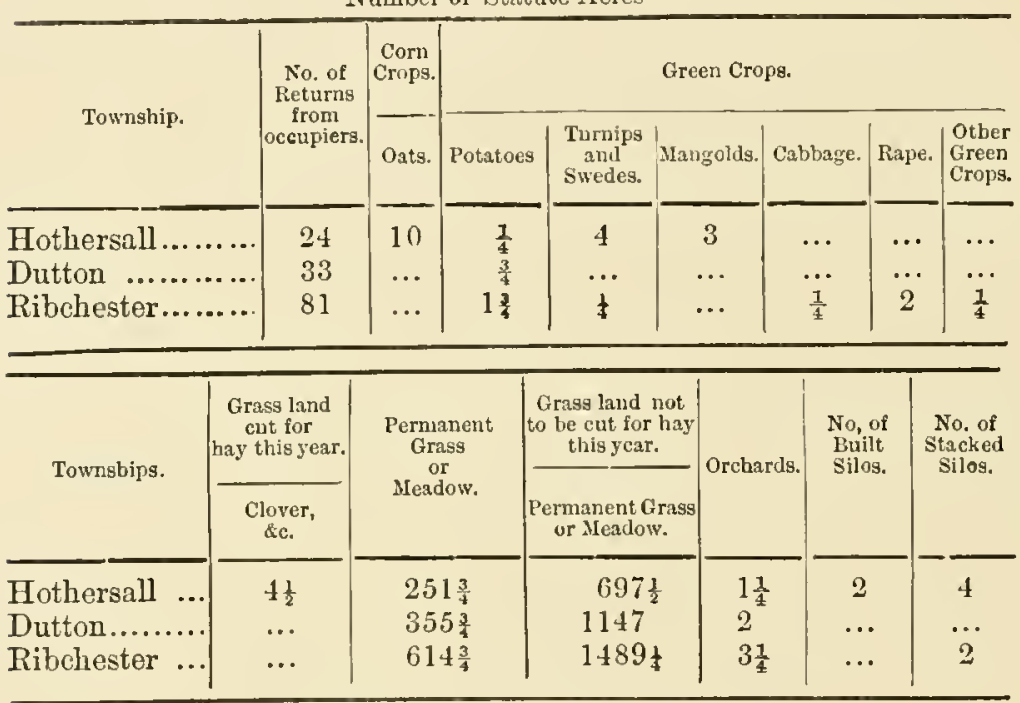

*Quantities less than $\frac{1}{\text {-acre not included. }}$

Live Stock on 4TH June, 1886.

\begin{tabular}{|c|c|c|c|c|c|c|c|}
\hline \multirow{3}{*}{ Townshipg. } & \multirow{3}{*}{$\begin{array}{l}\text { Number } \\
\text { of } \\
\text { Returns } \\
\text { from } \\
\text { occupiers. }\end{array}$} & \multicolumn{3}{|c|}{ Number of Horses. } & \multirow{3}{*}{$\begin{array}{l}\text { Number of } \\
\text { Cows and } \\
\text { Heifers of all } \\
\text { ages in Milk } \\
\text { or in Calf. }\end{array}$} & \multirow{2}{*}{\multicolumn{2}{|c|}{$\begin{array}{l}\text { Number of Cattle } \\
\text { other than those in } \\
\text { Mlilts or in Calf. }\end{array}$}} \\
\hline & & \multirow{2}{*}{$\begin{array}{c}\text { Used } \\
\text { solely for } \\
\text { Agri- } \\
\text { cultural } \\
\text { Purposes. }\end{array}$} & \multirow{2}{*}{$\begin{array}{l}\text { Unbroken } \\
\text { Horses } \\
\text { of any } \\
\text { age. }\end{array}$} & \multirow{2}{*}{$\begin{array}{c}\text { Mares } \\
\text { kept } \\
\text { solely for } \\
\text { Breeding }\end{array}$} & & & \\
\hline & & & & & & $\begin{array}{c}2 \text { years } \\
\text { and above }\end{array}$ & $\begin{array}{l}\text { Under } \\
2 \text { y'ears. }\end{array}$ \\
\hline Hothersall & 24 & 19 & 2 & 1 & 157 & 127 & 194 \\
\hline Dutton .... & 33 & 19 & 16 & ... & 243 & 95 & 227 \\
\hline Ribchester. & 81 & 42 & 11 & 1 & 382 & 104 & 403 \\
\hline
\end{tabular}




\begin{tabular}{|c|c|c|c|c|c|c|c|}
\hline \multirow{2}{*}{ Townships. } & \multirow{2}{*}{$\begin{array}{l}\text { Number of } \\
\text { Sheep of all } \\
\text { kinds one } \\
\text { year old } \\
\text { and above. }\end{array}$} & \multirow{2}{*}{$\begin{array}{l}\text { Number } \\
\text { of Lambs } \\
\text { umder } \\
\text { ouse year } \\
\text { old. }\end{array}$} & \multirow{2}{*}{$\begin{array}{l}\text { Number } \\
\text { of Pigs } \\
\text { of all } \\
\text { kinds } \\
\text { anel ages. }\end{array}$} & \multicolumn{4}{|c|}{ Number of Pcultry. } \\
\hline & & & & Turkeys. & Geese. & Ducks. & Fowls. \\
\hline IFothersall . & 247 & 243 & 25 & & 49 & 229 & 847 \\
\hline Inution $\quad . . . . . .$. & 447 & 177 & 17 & 5 & 13 & 199 & 1126 \\
\hline Ribchester ..... & 368 & 232 & 79 & ... & 9 & 294 & 2298 \\
\hline
\end{tabular}

*Probably considerably under the uumbers. 
CHAPTER VIII.-CHIPPING.

The De Chepyns-Earls of Derby - Welds-Origin of name-Thornley-Lord of the Manor-"History of Chipping"-Industries-Brabin's School-Old housesHesketh End-E. Kirk-Newlands and "pig eating"--Agricultural StatisticsPopulation-Non-jurors in 1715-The Parish Church: Fout-Value of living: 1244-92-1535-1617-List of Vicars - Rev. John Milner-Rev. John WesleyRev. E. Wilkinson-Church registers-Rev. R. Robinson-Rev. J. B. JonesThornley School-Catholic Church : List of Priests-Rev, Fr. I. J. de GryseLee House Church-List of Priests-Peter Walkclen: Extracts from diaryAgricultural Notes-Leagram Hall-Rev. Fr. Penketh-Foley's Diary-Ancient Anortuary paper-Anniversaries-Stole and Maniple-John Weld, J.P.-Death of Mr. Weld-Obituary Notice-Stonyhurst Maguine.

Chrpping, or as it was anciently written "Chepin," is five miles distant from Longridge, in a north-westerly direction. The Roman road from Ribchester to York passes through a portion of the parish. According to the "Status de Blaghorneshire," Chepyn was one of the three parishes which branched from that of Whalley some years before the reign of Edward the Confessor (1041).

Chipenden is mentioned in Domesday as having three carucates of land. According to the Lansdowne MSS., the heir of Thomas de Osbaldestone held in service one carucate of land in Wetheley and Thorneley. 'The heir of John del Hall, of Chipyn, also held a certain tenement in Chepyn for the fortieth part of one fee. The De Chepyns were Lords of the Manor down to 1348, when they were succeeded by the Iinolles. In 1515, the Sherburnes became Lords of the Manor, from whom it passed into the family of the TVelds.

Michael Doughtie, who was elected M.P. for Preston in 1588, was also one of the Clerks of the Kitchen in the semi-regal household of Edward, the 3rd Earl of Derby, and Henry, the 4th Earl of Derby; and, according to MIr. Payne Collier, "was an influential and rery" rich man." He purchased the manor of Thoruley-with-TWheatley, lands in Chipping, and was succeeded by his son, John Doughtie, whose daughter and heiress, Elizabeth, married Thomas Patten, Esq., MI.P. for Preston, an ancestor of Colonel Wilson-Patten, M.P. (Lord Winmarleigh). Mr. Patten's only daughter was married to Sir Thomas Stanley, Bart., an ancestor of the present Earl of Derby; the Earl, who lias royal blood in his reins, thus also deriving his descent from a squie who ras Clerk of the Kitchen to two of his ancestors at Knomsley. 
As heir to Michael Doughtie, and not by purchase, as erroneously stated by Baines, the Earls of Derby derive their possessions at Thomley and Chipping."

On 28th August, 1572, among the estates possessed by the Earl of Derby, as declared in his will, was the manor of Thornley.

Part of Chipping is owned by the Earl of Derby. John Weld, Esq., of Leagram Hall, also possesses land in Chipping.

The rarious ways of spelling Chipping which I have found, are: Chipyn, Chependen, Chejyn, Chipen, Chepin, Chypyng, Chippin, Chyppingge. The meaning of the word, according to Professor Blackie, is - a place of merchandise, from A.S. Ceapam, Ger. Kaufen (to buy). Dr. Taylor says: "A chipping was the old English term for a marketplace; thus Ticliffe translates Lnke vii, 32, 'They ben like children, sitting in chepinge, and spekinge togidre."

The ways of spolling Thornley and Wheatley are very uumerous:Thorentelega, Thorudeleghe, Thorndeleie, Thorndeleye, Thornedelay, Thornedeleghe, Thornedeleye, Thornelay, Thorneley, Thornesdeleye, Thomideley, Thornlay, Tornelay.

Dr. March gives the derivation of Thomley as the pasture (ley A.S. leah, or $\operatorname{leg} h$ ) amid the thorn.

Wheatley, Weetlee, Wetelai, Wetelay, Wetelegh, Weteley, Whetlay, Whetley, Whetlay, Whetley, Whitley.

The two townships of Chipping and Thornley-cum-TVheatley cover an extent of 8,756 statute acres. The Earl of Derby, K.G., is Lord of the Manor of Chipping, and also Lord of the Manor of Thornley-cumWheatley.

By the kindness of Mis. Jones, wife of the Vicar of Chipping, I have been enabled to obtain a coly of a very scarce "History of Chipping," written in 1843 by her father, the late Rev. Mr. Pearson, Vicar of Fleetrood.

The author says: "The earliest account we have of the individual history of Chipping, is founded on an ancient document, supposed to have been written in the fourteenth century, by John Lindley, Abbot of Whalley, which states that its inhabitants were few, untractable,

'Canon Raines's Notes to the Stanley Papers. 
and wild, and that there were multitudes of foxes and destructive heasts, while the place itself was in a manner inaccessible to man; that, owing to these causes, the Diocesan Bishop of Lichfield, and his officials, relinquished the whole jurisdiction of ordiwaries, etc., in these districts, and that this state of things continued for 470 years, until the reign of William the Conqueror."

There is some very fair grazing land in Chipping, while there is an abundance of limestone in the locality, the burning of which affords occupation to a number of people. Iron-working and chairmaking are the principal trades flourishing in Chipping.

The stone quarry of the Earl of Derby, in Thornley, affords employment to about 20 men. Bricks and tiles are also burnt on the Derby estate in Thornley.

The families resident in this parish liave occupied their houses for centuries, content in their obscurity, and undisturbed by the march of civilisation. The Earl of Derby is a most indulgent landlord, and is highly popular among his tenants. His resident agent is Mr. Trench.

The village of Chipping is situated on a brook, bearing the same name, at the foot of Parlick Pike, a mell-known hill, 1,416ft. high. Brabin's School, now disused, stands at the entrance to the village, on the road from Longridge, and on the door is carved in antique characters the, following inscription :- "This Schoole founded by John Brabbin, Gentleman, Doce, Disce, Tel Disecde, 1684, C.P.; R.P.; I.H.; R.MI." These initials refer to Christopher and R. Parkinson; John Hawthornthwaite; and R. Marsden.

Among the old and historic houses in the neighbourhood of Chipping may be mentioned: Wolfhouse; Hesketh End (on which Baines says are inscriptions to commemorate the landing of the Romans, Saxons, and Danes, the Norman Conquest, and the Protestant Reformation). Mr. E. Kirk, describing a visit paid to Fesketh End, says: "Scattcred about the walls, in the farm buildings, are stones with letters and figures upon them. Over the principal entrance to the house is the following: "Derm time, regem honor, proximum arna. IIto fae et Fire in etermum.' These are unquestiunably the work of some Puritan orner. The characters are not all Ruman, and some of 
the letters are not accurately cut; the ' $n$,' for instauce, lias often the midale line placed ohverse way. Built in one of the ontbuildings is a stoue E $1588 \mathrm{R}$ Qnery, is this Elizabeth Regina?"

Mr. Pearson states that Hesketh End was built by the Ashton family about A.D. 1501, and was, in 1843, the property and residence of Mr. Thomas Cardmell.

The writer visited the house, which is now occupied by Mr. Shaw, a short time ago. After carefully examining the place, and noting the numerous crosses and religions devices, e.g., I.H.C. carred all over the house, I think there can be little cloubt that it was formerly a place of morship. We know of no builling for miles aronnd which is so well worth a visit by the antiquarian or cmiosity-hunter.

Nicholas Assheton in his diary, printed by the Chetham Society, has the following note about Nerlands, a famous cottage close by Farrick ${ }^{1}$ : "1618, Jume 25. Divers gentlewomen from Stonyhurst called ther, and soe to a pig eating ${ }^{2}$ at Newlands ; made merrie."

The other old houses are-Higher Core; and Wood Gate (the birth place of the Rev. Canon Parlinson, the author of the "Old Church Clock," and numerous other works); Patten Hall (or Thornley Hall), long the residence of the 1'atten family; and Bradley Hall. There are also remains of old crosses at Wheatley Brook, Chipping Town End, and in the Churehyard.

The river Loud-slow and sluggish-Hows through Chipping, falling into the Hudder a little helow Whitewell.

There are several charities for the benefit of the poor, the yenrly income from which amounts to about $\mathfrak{E}: 300$.

The census returns of Chipping are:

$$
\begin{aligned}
& 1801-1214 ; 1811-1440 ; 1821-1735 \text {; } \\
& 1831-1850 ; 1841-1675 ; 1861-1625 \text {; } \\
& 1861-1483 ; 1 \times 71-1541 ; 1881-1336 .
\end{aligned}
$$

" Farrick, Fareoke, or Fair Oak House, anciently called 'Fair del Holme,' was in possession of Scoml. church, 21 Mar., and then passed to the Harrisons by marriage in 1668 , from whom it went to the Parkers in
1720-40." " "Pic-nic."

For a full account of the life of this distinguished son of Chipping I must refer the reader to the Old Church Clock.

4Whit. Whalley, II., 482, 483. 


\section{Agricultural Statistics.}

Number of Statute Acres under-*

\begin{tabular}{|c|c|c|c|c|c|}
\hline \multirow{2}{*}{ Township. } & \multirow{2}{*}{$\begin{array}{l}\text { No. of } \\
\text { Returns } \\
\text { obtained } \\
\text { from } \\
\text { oceupiers } \\
\text { of land. }\end{array}$} & \multirow{2}{*}{$\frac{\text { ConN Crops. }}{\text { Oats. }}$} & \multicolumn{3}{|c|}{ Green Crops. } \\
\hline & & & Potatoes. & Cabbages. & $\begin{array}{l}\text { Other } \\
\text { Green Crops. }\end{array}$ \\
\hline $\begin{array}{l}\text { Thornley-with- } \\
\text { Wheatley ......... } \\
\text { Chipping ........... }\end{array}$ & $\begin{array}{r}56 \\
104\end{array}$ & $\ddot{1}$ & $\frac{\frac{1}{2}}{1 \frac{3}{4}}$ & $\begin{array}{c}\frac{3}{4} \\
\ldots\end{array}$ & $\dddot{1}$ \\
\hline
\end{tabular}

\begin{tabular}{c|c|c|c|c|c|c}
\hline Township. & $\begin{array}{c}\text { Grass Land cut for hay } \\
\text { this year. }\end{array}$ & $\begin{array}{c}\text { Permanent } \\
\text { Grass or \$leadow } \\
\begin{array}{c}\text { Clover, } \\
\text { \&c. }\end{array}\end{array}$ & $\begin{array}{c}\text { Permanent } \\
\text { Grass or } \\
\text { Meadow. } \\
\text { Got to be cut } \\
\text { for hay } \\
\text { this year. }\end{array}$ & Orchards. & $\begin{array}{c}\text { No. of } \\
\text { Built Silos. }\end{array}$ & $\begin{array}{c}\text { No. of } \\
\text { Stacked } \\
\text { Silos. }\end{array}$ \\
\hline $\begin{array}{c}\text { Thornley-with- } \\
\text { Wheatley ... }\end{array}$ & $\ldots$ & $658 \frac{3}{4}$ & $1930 \frac{1}{2}$ & $1 \frac{1}{2}$ & 1 & 2 \\
Chipping ......... & 1 & $1108 \frac{1}{2}$ & $3133 \frac{1}{1}$ & $3 \frac{3}{4}$ & $\ldots$ & 6 \\
\hline
\end{tabular}

* Quantities less than $\frac{1}{4}$-acre not included.

Live Stock on 4tH June, 1886.

\begin{tabular}{|c|c|c|c|c|c|c|c|}
\hline \multirow{2}{*}{ Township. } & \multirow{2}{*}{$\begin{array}{l}\text { No. of } \\
\text { Returns } \\
\text { obtained } \\
\text { from } \\
\text { occupiers } \\
\text { of lind. }\end{array}$} & \multicolumn{3}{|c|}{ NuMser of Horses. } & \multirow{2}{*}{$\begin{array}{c}\text { Number of } \\
\text { Cows and } \\
\text { Heifers of all } \\
\text { Ages, in Milk } \\
\text { or in Calf. }\end{array}$} & \multicolumn{2}{|c|}{\begin{tabular}{|c} 
NUMBER OF CATTLE \\
OTHER THAN THOSE IN \\
MILK OR CALF. \\
\end{tabular}} \\
\hline & & $\begin{array}{l}\text { Agricul- } \\
\text { tural } \\
\text { Solely. }\end{array}$ & $\left|\begin{array}{c}\text { Un- } \\
\text { broken } \\
\text { Horses } \\
\text { of any age }\end{array}\right|$ & $\left|\begin{array}{c}\text { Mares } \\
\text { kept } \\
\text { solely for } \\
\text { Breeding }\end{array}\right|$ & & $\begin{array}{l}2 \text { years } \\
\text { old and } \\
\text { above. }\end{array}$ & $\begin{array}{l}\text { Under } \\
2 \text { years. }\end{array}$ \\
\hline $\begin{array}{l}\text { Thornley-with- } \\
\text { Wheatley ... }\end{array}$ & 56 & 52 & 17 & 1 & 366 & 126 & 374 \\
\hline Chipping......... & 104 & 75 & 30 & $\ldots$ & 773 & 317 & 600 \\
\hline
\end{tabular}




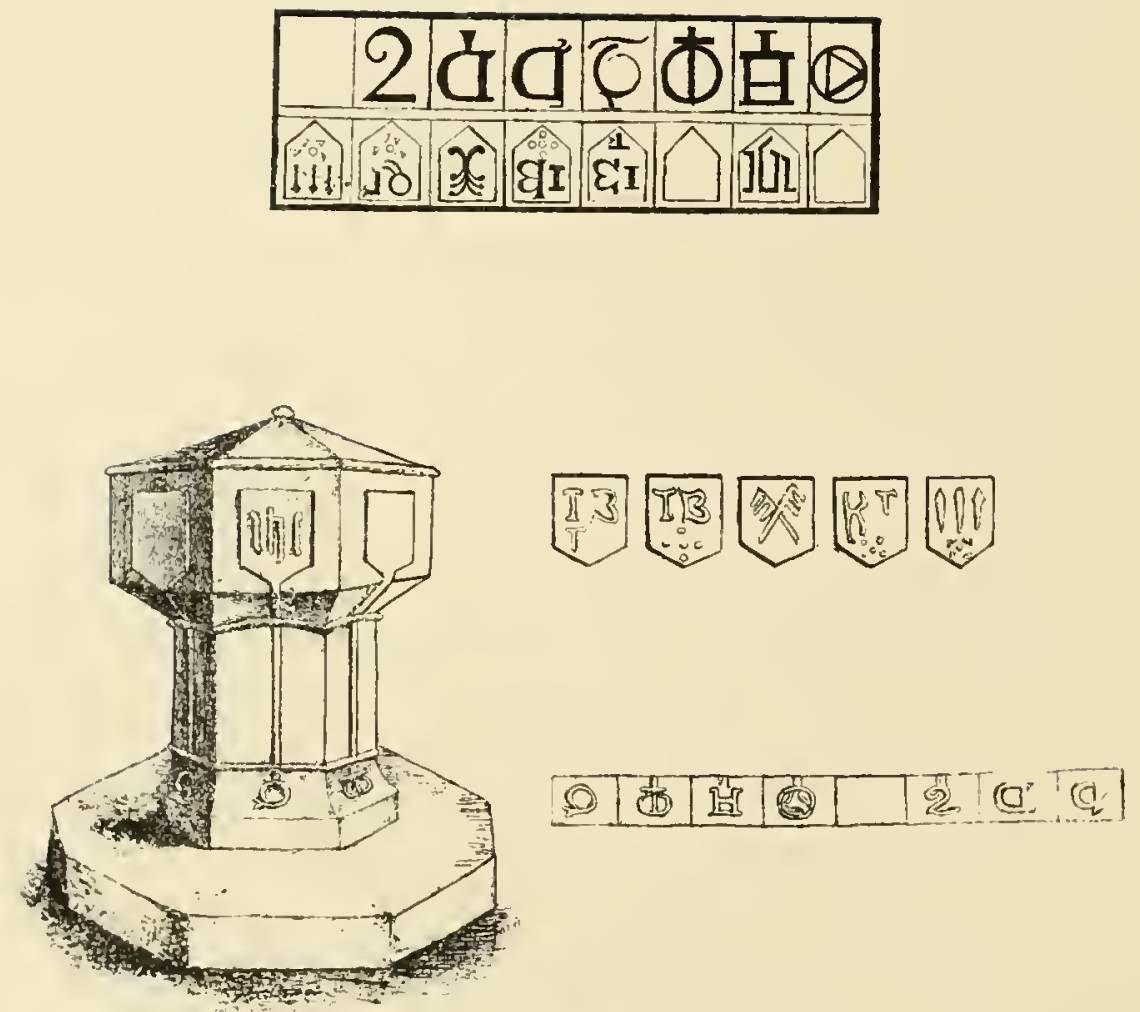

FONT IN CHIPPING CHURCH. 


\begin{tabular}{|c|c|c|c|c|c|c|c|}
\hline \multirow{2}{*}{ Township. } & \multirow{2}{*}{$\begin{array}{l}\text { Number of } \\
\text { Sheep of } \\
\text { all kinds } \\
1 \text { year old } \\
\text { asid above. }\end{array}$} & \multirow{2}{*}{$\begin{array}{c}\text { Number } \\
\text { of lambs } \\
\text { under } \\
\text { one } \\
\text { year. }\end{array}$} & \multirow{2}{*}{$\begin{array}{l}\text { Number } \\
\text { of Pius } \\
\text { of all } \\
\text { kinds } \\
\text { and ages. }\end{array}$} & \multicolumn{4}{|c|}{ Number of Poultry.* } \\
\hline & & & & Turkeys. & Geese, & Ducks. & Fowls. \\
\hline $\begin{array}{l}\text { Thornley-with- } \\
\text { Wheatley ... }\end{array}$ & 1010 & 669 & 47 & $\ldots$ & 29 & 107 & 1333 \\
\hline Chipping......... & 1982 & 1727 & 101 & 34 & 133 & 189 & 1636 \\
\hline
\end{tabular}

* Probably considerably under the numbers.

NoN-JuRORS IN 1715.

Jeanett Duckworth, Leagram, widow, house and $38 \frac{1}{2}$ acres of land there and at Chipping.

James Dobson, Leagram, husbandman, 2 houses and 11 acres charged with $£ 11$ to his sisters. . . $£ 46$ s. 0 d.

James Parker, Chipping, yeoman, freehold, and amount of $£ 18$ out of a house at Bolland-cum-Leagram, tenanted by his son-in-law Edward Parker. . . $£ 19$.

Robert Houlden, Laithgrym, husbandman, leasehold farm.

James Richmond, Chipping, yeoman, house and 21 acres. . . $£ 8$.

Thomas Wilcock, Chilping, husbandman, house and 16 acres.

John Bolton, husbandman, leasehold farm. James Lowde, tailor, leasehold. Jolın Dewhurst, husbandman, leaseliold there and farm at Bolland.

Bartholomew Dilworth, husbandman, freehold house and 38 acres.

Thomas Dobson, husbandman, leasehold houses and 15 acres.

\section{The Parish Church.}

The Parish Church of Chipping, dedicated to St. Bartholomew, is a neat stone edifice; the date of its foundation being about 1041. The Church was partly rebuilt in 1520 ; was re-seated and altered in 1706 ; and was thoroughly restored in 1868 .

It is believed that the original foundation of the old Church was laid somewhere about A.D. 596. In the Churcli are three ancient holywater stonps.

The feature of greatest interest in the Church is the font. "It was probably erected," says Whittaker, "in the time of Henry VIII."; but the figures carred thereon are of much older date. 
"The figures, which were printed iu the Gentleman's Mugazine and the first editions of the Mistory of Whalley, were not only reversed, but were incorrect and ont of proportion. Mr. Brooke-Herford, editor of the second volume of the second edition of Baines, who discovered this perristent and lorg-standing error, says: "The artist has committed the complicaterl mistake of placing the figures together, as if they formerl a single inscription, and of making the small figures about the pedestal larger than the devices with shiclds." "

The five shields not shown in the figure of the font bear the implements of the Passion and initals explained by Mr. BrookeHerford as M., I.B., and J.B., relating to the Hoghtons, Lords of the Manor, and the Bartons and Browns, landholders in Chipping, during the sixteenth century. The letters in the perlestal which are here reversed as on the font were explained by Mr. J. G. Nichols as P.D.T., A.M.G., signifying: Ave Iraria Gratia Petena Dominus Tecum. ${ }^{2}$

In the Church are also tablets to the memory of the Rev. E. Wilkinson, Mr. James Dilworth, and others; and a brass to the memory of the Parkinsons, of Fairsnape.

Mr. Pearson says that, in 1241, the Prior of Lancaster claimed the right of presentation to Chipping Church, a claim which was, however, disallowed.

"In 1241, Emeric de Roches" also claimed "the Church of Chyppindale" as "a Chapel of his own, at Preston, but subsequently remitted his claim, on the grounds that the living had been last presented by the Earl of Lincoln."

"At the inq., p. m., of Henry, Dnke of Lancaster, 28 Ap., 1361, it was found that he held the adowson of the Church of Chif,en, Valor 20 Narcas. The Church of Chippyng was valned at $£ 10$ 13s. 4 d. by the taxation of Pope Nicholas IV., 1244-92; and by the new taxation made in 1318 , on account of the invasion of the Scots, at $£ 5$. By inquisition taken at Lancaster, 26th Feb., 1341, it was found that, although the Church at Chypyn 'taxata sit ab antiqua a xvj. marcas isto tamen tempore nona gurbarum cjusdem parochie juxta verum valorem valet nisi Cs. et non plus, unde villate de Chypynn respondet de Ls. et Thorneley

${ }^{1}$ Whitt. Whalley. 
de $L s . ; '$ that there were no lambs or' wool in the parish belonging to the King, nor any merchants or other men living without agriculture who give the fifteenth of their goods; that the glebe was worth xxs. a year, 'decimes fenis et alie minute decime, oblationes et alia spectaneia ad altaragium qui valent commeniter per annum iij marcas. Et etiam dicta parochia destructa fuit per Scottas. Ita quod ratione ejusdem destrucionis jacent in eadem parochia terre vaste et inculte in diminutione dicte taxe singulis annis per $x l s . '$

"The Rectory of Chipping, an impropriation belonging to the Bishop of Chester since 1542, was valued in 1535, in the King's books, at

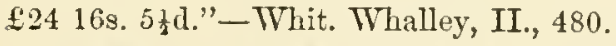

"Sciant, ete., quod ego Rog. de Lacye Constabl. Cestr. Dedi etc. Johanni de Dunkekanlega $j$. bovatum terre cum pertinenciis in Filla [de] Chippin, illam scilicet quam Alexander de Chippin prius tonuit-habcndum illi et heredibus suis de me et heredibus meis libere, etc.-reddendo inde annuatim mihi et heredibus meis 12d. ad festum Sancti Egidii, etc., testibus, Galfrido decano de Wallita, Hug. de Dutton tunc. Senescallo, Tho. Dispensatore, Rald. de Rossa, Ricardo Ponte Garde, Tho. de Terdon, et multis aliis."

In the report, dated 28 Sept., 1647, of the survey of lands, the following statement is madc regarding Chipping :-

"The same Rectory or Personage, with all Messauges, Cottages, Glebe and Demeasne lands, 20 Sept., 40 Elizabeth [1598], was leased by Richard, Bishopp of Chester, to Robert Swindlehurst for his owne life; Thomas Swindlehurst, his brother, and Richard Swindlehurst, the said Robert's younger Cozen, and the longest lives of them. Richard is onely liveing, aged 57, and in health.

"Mris. Mary Harris, a Papist, now wife of Christopher Harris, a Papist in armes, is sole daughter and heir of the said Robert Swindlehurst, the Lessee, and is yet living, but the Rectory stande sequestred.

"Mr. Edward Parker, a Lawyer living at Brownsholme, in Couuty" York, hath the lease, intending to drawe the said Robert Swindlehurst his will by it, but did it not before he died. The Parrish consists of Townes, viz., Chippin, Thornely, Wheately, etc.

"There is a faire Parsonage house, and about five acres of gleable, great measure, with liberty to gitt turbary, all which is valued to be 
worth seaven pounds per annum. The aforesaid Richard Swindlehurst dwells in the house, and claims all the gleable and Rectory by occupancy. And he hath assigned it to his Sonne, Ralph ffarber, of Hayning, in the County of York, for money due. And the said Ralph hath assigned it to Mr. Hugh Currall [Currer], of Bradford, Clothier. But the Committee for Sequestrations, and their deputies, Mr. Charles Gregory, of Haslingdine [Haslingden], and Mr. John Haworth, neere Dunghall [Dunkenhalgh], three myles from Whaley [Whalley], have sett the Tythes to Captain Clement Townson, of Stakes, ${ }^{2}$ and they pay the Rent of Twenty five pound one shilling and eightpence reserved to the late Bishopp (viz.), Fifteen pounds one shilling and eightpence to the now Committee of Trustecs aud Treasurers for the Sale of Bishopp's lands, and tenn pouuds residue to the now Vicar, Mr. John Fing, instituted and inducted. And the 27 Aug., 1647, Mr. King had an order from the Committee of Plundered Ministers to receive flifty pounds per annum more out of the profitts of the Impropriate Rectory of Chippin Sequestered from the said Mr. Harris. I conceive the house and gleable, with the appurtenances, may be well worth Twelve pounds per annum, And according to that rate I doe apportion the resurved rent, viz:-

$$
\begin{array}{lllllllll}
\text { To thie lands } \ldots & \ldots & \ldots & \ldots & \ldots & \ldots & \ldots & 02: 11: 8 \\
\text { Tythes ... } & \ldots & \ldots & \ldots & \ldots & \ldots & \ldots & \ldots & 22: 10: 0 \\
\end{array}
$$

ffeb. 7th.

Will. Webb, 1655 .

"The late Bishopl did present the said Viccar. The Personage house, gleabe, and Rectory was worth to be lett upon the racke before the warres One hundred tweuty-six pounds sixteene shillings eightpence per annum, all payments included; viz: the Towne of Chippin, Eighty pounds per annum, out Townes Tweuty-six pounds, Easter booke Foure pounds, wooll Foure pounds tenn shillings, lambes Two poundes, calues One pounde tenne shillings, geese one pound six shillings eightpence, eggs five shillings, piggs five shillings; the Parsonage house, gleabe, aud turbury, one pound per annum; 
quers, what Chappells of Ease nud meanes, and also the Tythes of Bradlcy Hall, a member of Thornely, yet in lease to Robert Poulton at three pounds per annum be not forgotten.

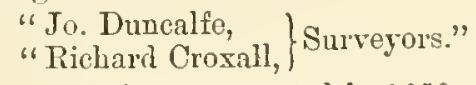

The Lancashire Church Survey Commissioners reported in 1650 :"That Chipping is a parish, and doth contayne within itself one Parish Church, viz., Chippin, a Tiecarage representative impropriate to the said Bishop of Chester (the tythes thereof nnder sequestration worth per annum Eighty-five pounds and five shillings). And that the tythes of Thornley-cum-Wheatley, parte of the said parish, is worth per annum Twenty pounds, besydes the tythe of one antient messauge and Twoe hundred acres of land called Bradley, demised by the late impropriator the said Bishop for a terme determinable at Candlemas next. And the inhabitants subscribe to paie fifteeno shillings one penny per annum to the ffarmer of the Rectory of Chippin, viz., twoe shillings foure pence, for an acre of oates, pease, and beanes, thrce shilling, and an acre of barley, five shillings, and an acre of wheat. And that the said tome people of Thornley-cum-Wheatley are distant from their p.rish Church three myles; the present minister, Mr. John Kinge, an able orthodox divine, hee hath for his sallery Ten pounds per annum, formerly paid out of the rent reserved to the said Bishop, and since the profits were sequestered hee hath received an augmentation of fiftie pounds per annum by order of the Committee for Plundered Ministers, so that his whole stipend is sixtie pounds per anntum."

"Jopas of the Hall of Schippen held a piece of Iand in Schippen paying yearly . . . . jd. . . Thomas son of Ruth for his tenements in Schippen.

"There is a capital messauge yenly worth $\mathrm{rj}^{\mathrm{d}} 100$ acres of land . . pay yearly xxxiijs.iijjd, 8 oxgangs of land . . . pay ycarly xxiiij."

$$
\begin{array}{rrl}
\text { Oct. } & 8,1591 & \text { Richard Parker. } \\
\text { Uct. } & 5,1616 & \text { William Armetsdaile. } \\
& 1622 & \text { Joln King. }
\end{array}
$$


1674 Richard White.

Aug. 12, 1692

Dec. 23,1701

Aug. 19, 1721

Nay 29, 1738

Feb. 19, 1738-9

Mar. 11, 1778

Aug. 3, 1779

Nov. 31,1786

May 10,1807

Nov. 28, 1816

1864

1886
Humphrey Briscoe.

Thomas Atherton.

Thomas Clarkson.

William Rawsthorn.

John Milner.

Thomas Pearce.

William Stockdale.

John Carlisle.

James Yenny.

Edmund Wilkinson.

Richard Robinson, M.A.

John Birch Jones, B.A.

REV. JOHN MILNER.

An inscription upon a white stone, on the south side of the altar, commemorates John Milner, Vicar, who died in 1777, aged sixty-seven, and who was a warm friend of the Rev. John Wesley, the founder of Methodism. In April, 1751, Mr. Milner was at Bolton, and Wesley records:-Thursday, 11 April.- "Hence I rode with Mr. Milner to Ribchester," where some elergymen had appointed to meet him; and the same evening he spent at Chipping Vicarage. He again spent the evening of Saturday, June 6, 1752, at the Vicarage, and preached the following day at Chipping Church. He says of the morning service : - "Such a congregation was present as I believe was never seen there before, and a solemn awe seemed to rest on the whole congregation from the beginning to the end." He adds:- "I preached in the afternoon . . . . The people were all attention." In July, 1752, he was again at Chipping, but there is no record of any service. In April, 1753, he paid his last visit to Chipping. On Saturday evening, April 7, he rode to Chipping, and on Sunday he went to church, Mr. Milner desiring that he shonld preach. He says:- "As soon as we came into the aisle of the Church from the Vestry, a mau (since dead) thrust himself between Mr. Milner and me, and said, 'you shall not go into the pulpit.' I told him 'I am only going into the desk.' He said, 'but you shall not go there neither,' and pushed me back by 
main strength. Eight or ten noisy men joined with him quickly, and set themselves in battle array. Fearing some might take fire on the other side, I desired Mr. Milner to begin the service. After prayers (for he had no sermon with him), great part of the congregation followed us to the Vicarage. They came thither again after evening service, and God made them large amends for their little disappointment in the morning."

Pasted at the beginning of one of the Parish Registers, ${ }^{1}$ is the following interesting memerandum :-

"Jehn Wesley, late Fellow of Lincoln College, in Oxford, ordain'd both Deacon and afterward Priest, by Dr. John Potter, late Archbishop of Canterbury.

"June 7, 1752."

"Benjamin Ingham, late of Queen's College, in Oxford, ordained by Dr. John Petter, late Archbishop of Canterbury.

"Dec. 24 \& 25, 1752."

Mr. Milner was appointed a King's Preacher on 9 Feb., 1748.

REV. E. WILEINSON.

The Rev. Edmund Wilkinson, who was Vicar of Chipping for the long period of 48 years, was a noteworthy man. He was for some years Parish Constable, as well as Vicar-rather dissimilar offices one would think now-a-days. Many curious tales of his adventures, when acting in this capacity, are current. Fishwick says, Mr. Wilkinson was curate at Whitechapel, and perhaps schoolmaster, from 1814 until his appointment to Chipping two years later.

Mr. Pearson gives the fellowing interesting account of Mr. Willkinson:- "As an individual, he is held in the highest respect by his own congregation, as well as by the members of other denominations, but it is in the rank of Pastor that his excellencies are most conspicueus. Assiduous in visiting the bedside of the sick, and prompt to impart

${ }^{1}$ Although the registers at Chipping date from 1560 , there do not appear to be any entries of general interest, beyond the bare announcement of births, deaths, and marriages.

One fact deserves mention. In 1844, the Rev. E. Wilkinson, Vicar of Chip- ping, copied the entries in the registers from $15 \% 0$ to 1754 , and compiled in adclition, a rather elaborate index. Needless to say, the task of consulting the registers has been greatly facilitated by means of this eminently useful work of the late Vicar of Chipping 
consolation and relief to the poor and distressed, he answers to the character which the apostle of old recommended to the ancient Bishop of Epliesus, one which might be well enforced on a large majority of our rural clergy. As a preacher, his language is remarkably pure, forcible, and easy to be understood. His words are all of them sought out and solected, on the principle of being the most familiar in which ideas can be conveyed. For the same reason his sentences are short and clear in their structure; neither loaded nor involved, but perspicuous and intelligible. His style is not meagre, but enriched with some of the finest and most classical terms which the example of the best writers has sanctioned among us. His utterance, though rapid, is perfectly distinct; every word falls full and harmonious on the ear, whilst its very rapidity fixes attention, and by that means gives greater effect to his discourses."

REV. R. ROBINSON.

The Rev. Richard Robinson, M.A., T.C.D., was Curate of Salesbury from 1860 to 1862 , and was for two years Curate of Chipping before his appointment as Vicar in 1864. He was born at Goosnargh. Mr. Robinson is quiet and gentlemanly-looking, with an air of precision about him which is at first rather trying to a stranger. His style of preaching is very vigorous, quite unlike his reading style. He was, we believe, popular amoug his parisioners, although his habits of tenacity were not love-iuspiring. In 1886 he resigned the living of Chipping on his appointment to Carlton-on-Treut, Notts.

REV. J. B. JONES, B.A.

The Rev. John Birch Jones was appointed Vicar of Chipping in 1886, on the resignation of the Rev. R. Robinson. Mr. Jones has filled Curacies at IIulme and Bury. Of course, Mr. Jones has not been sufficiently long enough at Chipping for us to form an estimate of his work there; but we understand ho is popular among his people. As a preacher he is fairly successful, reads his sermons, and is somewhat hard to understand.

The value of the living of Chipping Church as returned in the Diocesan Almanack is $£ 306$ per annum, with house. The Bishop of Manchestor is patron of the living. The number of sittings is 442 , all of which are free. 
About half-way between Chipping and Longridge is Thornley School, erected a few years ago by the Earl of Derby. The building is of an extremely tasteful character, and presents a pleasing aspect to the eye. The School will accommodate about 200 children; and is used as a Church on Sundays, service being performed alternately by the Vicars of Longridge and Chipping.

\section{Catholic Church.}

Chipping Catholic Chapel, dedicated to St. Mary, is situated at the entrance to the Village, just below Brabin's School. It is a good stone structure, square shaped, and has a clean and tasteful interior. The Chapel will seat about 400 persons.

\section{List of Priests at Chipping.}

1780 Rov. John Lawrenson.

1800 Rev, R. Summer.

1803 Rev. John Reeve.

1828 Rev. E. Morron.

1838 Rev. J. T. Bateman.

1839 Rev. J. B. Bridge.

1840 Kev. F. Poole.

1840 Rev. T. MeClane.

1841 Rev. J. Middlehurst.

1843 Rev. J. S. Knight.

1844 Rev. W. O'Brien.

1845 Rev. R. Raby.

1816 Rev. J. Bateman (second time).

1857 Rev. H. de Blon.

1860 Rev. J. Newton.

1861 Rev. Cauon Rimmer.

1865 Rev. I. J. de Gryse.

The present priest is the Rev. John de Gryse, a tall, slender, rather young-looking gentleman. "He can twist his features," says "Atticus," "in all ways, and can perhaps talk better" with his face, without opening his mouth, than any gentleman you ever met with." Mr. de Gryse is a Belgian, but can speak English very well. He is about 50 years of age, and was born at Ghent in Belgium. He is very 
genial and kindly, but shrewd and hardworking, lives a quiet and retired life among his books, and is deservedly respected and popular.

Near the Chapel there is a good School, with an average attendance of about 80 .

\section{Lee House Church.}

About two miles from Longridge, on the road to Chipping, is Lee House Roman Catholic Chapel, Thornley. It is a modest little bnilding, dedicated to St. William, and was erected in 1738 , when a Catholic Mission was founded there by Mr. Thomas Eccles, of Lee House. It was formerly under the Franciscans, then under the Secular Clergy, and it is now under the Benedictine Order. From 1841 to 1859 , the Chapel was closed. There is the stone base of an old Pilgrim's Cross in the graveyard. Father Trappes caused this cross base to be brought hither from the old road between Chipping and Longridge. The tradition is, that it took a number of horses and men to remove it; and that, seeing how difficult it was to remove, people were afraid to go near it, but were eventually pacified.

The interior of the Chapel is very plain. The building will seat about 150 people, the average attendance being somewhere about fifty. There are some tablets in the Church.

List of Priests at Lee House.

1738 Rev. G. Holmes, O.S.F. ${ }^{1}$

- Rov. F. Clarke, ,

1752 Rev. Leo Francis, ",

- Rev. P. Price, ",

- Rev. H. Wareing, ",

1800 Rev. J. Tate, ",

1816 Rev. J. Davison, ",

1820 Rev. T. Kington, ,"

_ Rev. J. Davison (second time).

1826 Rev. P. Orrell, Secular.

1827 Rev. F. Trappes.

1859 Rer. George Alban Caldwell, O.S.B.

1868 Rev. J. B. Murphy, ,"

${ }^{1} \mathrm{Fr}$. Holmes was martyred at Lancaster. 


$\begin{array}{llr}1870 & \text { Rev. R. C. Tyrer, } & \text { O.S.B. } \\ 1871 & \text { Rer. J. B. Murphy (second time) ", } \\ 1874 & \text { Rev. T. A. Atkinson, } & " \\ 1876 & \text { Rev. W. J. Watmough, } \\ 1882 & \text { Rer. C. Procter, } \\ 1884 & \text { Rer. J. Dewhurst, } \\ 1886 & \text { Rev. F. E. Rcche, ", }\end{array}$

There is an "abandoned" Iudependent Chapel close to the Village; and there was formerly a Wesleyan Chapel, but it is a long time since it was used. Attaching, however, to the Independent Chapel in Hesketh Lane, which was converted into a dwelling house about fire years ago, there is a very interesting history. The Rev. Peter Walkden, who was the minister of the Chapel in 1725, wrote a diary for the years 1725,1729 , and 1730 , extracts from which woro published in 1866 by the late Mr. W. Dobson.

I preface the following extracts by a brief account of Mr. Walkden's life:-

Born in 1684, Mr. Walkden was probably appointed to Hesketh Lane Chapel in 1722, and probably stayed there until his death in 1769 , at the advanced age of 85 . The chapel was built in 1705 . On a stone over the doorway is the date of erection in Roman numerals, and there was the following inscription, but it is now almost illegible:

"Luke 7, 5-For he loved our nation, and he hath built us a synagogue."

The diarist's wife was interred in Hesketh Lane Chapel, and over her grave is an inscription, recording her death on the 5 th January, 1744.

On his death, Mr. Walkden was succeeded by his sou, the Rer. H. Walkden.

Mr. Walkclen's first reference to the immediate district, of auy listorical importance, is to John Singleton, " 0 ' th" Delph" (the stone quarry at Longridge.)

He also mentions the fact of Mr. Cottam "clarking" at a sale at the cross on Hurst Green. This Mr. Cottam was the schoolmaster of Hurst Green, and was the author of the songs of "Stonyhurst Buck Hunt" and "Hie away to Rossall Point." Further reference to Mr. Cottam will be found in Chapter IV. 
He refers to Hesketh End, a curious Elizabethan house, not far from the chapel. It has on the outside numerous inscriptions in Latin, etc., as mentioned before. It also bears the inscription: "RICHARD ALSTON ${ }^{1}$ MADE THIS HOUSE, ANNO DOMINI, 1582. O LORD, SAVE IT, AND BE KIND."

From his diary it would appear that at this time (1729) some thousands of acres of land were bog and moss, and that the land along the Thornley side of Longridge Fell was common land. It was not enclosed until 1807.

Mr. Pearson's notes on the state of agriculture in 1843 are worth reproducing. He says :-

"The inhabitants of Chipping were originally, and still continue to be, in a great measure devoted to this honourable pursuit, and though the old system of farming is generally adopted, they nevertheless have brought it to such a perfection as almost to outrival the polished efforts of modern agriculturists.

"The produce of wheat is not very considerable, but every other description of grain is cultivated with singular success. In the breeding of cattle, also, the farmers of Chipping surpass their neighbours in other parishes, and most of their commodities are sold either on the spot or at Preston market.

"The arable land in the township is about one-fourth of the whole, and the average rent is about $30 \mathrm{~s}$. the customary acre, or $15 \mathrm{~s}$. the statute acre."

$$
\text { Leagrait Hale and Chapel. }
$$

Mr. Weld, of Leagram, has very kindly favoured me with some interesting notes regarding the hall and chapel at Leagram, which are embodied in the following account:-

The present house stands on t'ie site of the ancient Park Lodge existing at least from the creatiou of the Duchy of Lancaster, and was used as a permanent or occasional residence by the officers appointed by the Crown to the Keepership of the Park. Early in the sixteenth century it became a dower house for the Sherbourne family of Stonyhurst, from whom, as I have said, it passed in 1752 into the Weld family. Mr. Weld's grandfather, Mr. Thos. Veld, of Lulworth Castle, took down the centre of the old house to erect a residence for the priest.

'Ashton? 
It was a post and pattern building, with a projecting uppor storey, forming a covered area underneath, with a terrace in frout. This was a very ancient building, and dated probably from the time of the Lacys. In $1821 \mathrm{MIr}$. Weld's father took down all that remained of the old house, and re-built the house in its present form.

The domestic chapel was erected by Mr. J. Weld in 1852 .

Lengram Hall is finely sitnated upon rising ground, and the park is nicely wooded. It is a well-bnilt mansion, aud contains some handsome rooms, in which are hung the family pictures. Attaching to the old chapel at Leagram is an interesting history, which is thus rolated by Foley:-

Cimpping Mission and Father John Penketh.

"In 'Records S.J.,' under the head of 'Chipping,' it is stated that, according to tradition, Father. John Penketh was missioner there; and, again, under the head of 'Stonylurst,' the same Father is treated as the earliest traceable missioner there. From a note by the learned editors of the 'Tyldesley Diary,' wo have reason to believe that the abovo missioner was not Father Johu Penketh, but the Rev. Richard Peuketh, priest, probably of the same family, and, in the opinion of Mr. Gillow, a Jesuit Father. We do not, however, trace such a member of the Society, and believe that he was a secular priest. IVe extract the following from the "Diary":- "June 5. Went early in the morning a fox-hunting, with Cos Wadsworth, to meet Mr. Penket, and found a fox, but could not holle him."

The Editors, in a note, state:-

"The Rev. Richard Penketh, or Pencoth, S.J., was the missioner at the Lawnd, as the Lodge of Leagram, or Laithgryme Park, was them called, and his burial is recorded in the register of Chipping Church. "Richard Poucoth, a Popish priest, buried August 7, 1721, of Chipping Lawnd." The oldest chapel at Leagram of which there is any knowledge, and of which there have been any remains found, stood on the high ground at the north-western extremity of the court-

1_- "James Parker, the taller, of Lea-
gram; and Janes Parker, the shorter,
of the same, depose this 18 th July, 1718 ,
that they rent part of Chipping Lawn

of Sir Nic. Sherburne, and know Mr. Penkard, a priest, and have hearl him Penkard, a priest, and hatin, what is called Mlass."-MIS., s. 100. 
yard of the Lawud. One old man, now living, aged eighty-three, remembers it in ruins when he was a boy; it was very small, and the walls of great thickness, as was evident by the foundations, when laid bare two years since (1871). This chapel would be in use at and after the time of Richard Shireburne's foundation, in the reign of James II. Abont 1787, Thomas Weld, Esq., erected a larger one on the site of the west wing of the old mansion, sixty feet in longth and twenty-five feet in width, with five long round-headed windows on one side; the inside being very plain, and the exterior more so. This chapel again proving too small for the growing wants of the congregation, shortly after the late Mr. Weld and his family came to reside at Leagram, a site was granted, with some land, by him, adjoining Chipping village, and a large chapel and a priest's house erected thereon, and opened for public worship in 1827. The old chapel at the Hall continued to be made use of for some years as a domestic chapel, but it eventually fell out of repair, a large portion of it was taken down, and the present Gothic chapel erected in its place."-Extract from "Diary and Pilgrim Book."-Foley.

"Chipping.-This ancient manol" was held by Richard de Chepin, Lord of Chepin, soon after the Conquest. It subsequently passed to the Knowles family, and afterwards to the Shireburns. Leagram Hall, now the seat of John Weld, Esq., with the manor, was granted by Qneen Elizabeth to Dudley, Earl of Leicester, of whom Sir Richard Shireburn purchased it. This mission was served from a very early period by the Fathers of the District, most probably from the mansion of Stonyhurst, the seat of the Shireburnes. According to tradition, Father John Penketh was missioner there. The mission ceased to be served by the Society in 1857 . The following is a copy of an ancient Shireburn mortuary paper, and instructions for the priost at Chipping. The original is preserved in the Archives of the College:-

"1. Hee is to celebrate three tymes a weeke, offering vpp one Masse for Richard Shirburn of Stonyhurst, Esqre., and Isabel, his wyfe. Another for their children and grandmother, and all whom they are in dntie bound to pray for living. A third for their friends departed. 
"2. He is to assist the Catholiques not otherwise provyded for in the parish of Long Preston and Gigleswick, continuing amongst them a week in everie month, and for other three weekes he is to assist such as are not provyded for in the parish of Great Mitton and Laythgream, and resyde amongst them.

"3. If it shall please Grod, eyther Mr. Shirburn or his wyfe do dye, and the other survyve, one of the Masses which were to be sayd for the living shall be whollie employed for his or her soul soe departing, and the second for the lyving must be said for the survyvor with a commemoration for the rest, but when the survyvor shall die also, then ye 2nd Massa shall also be employed solely for the benefit of his or her soul; soe of the throo Masses one shall be sayd then for the husband, another for the wyfe's soul, and the third for the good of their granddaughter Isabell Townley, lyving or dead, and of their posterity living, that they may serve God lawdable ever. In all a memento for their faithful departed friends.

"4. If any of the donor's children dye, the parents survyving, the Mass for the departed friends shall be sayd for itt, a yeare, with a commemoration of the faithful departed.

"5. If it slould please Grod that more children than one dye in one yeare, the parents survyving, when he has finished a trental for that which dyed first, hee shall begyn another for the second, and, that done, shall goe about to make vpp the Masses to a yeare's proportion.

"6. Itt is left to the priest's discretion what he will to take out of the Masses for the lyving for any child that shall die after the decease of both their parents.

"7. Hee shall keep the anuiversarye of their nearest friends, which they themselves (the MS. is here torn), keepe their owne and their children (M.S. torn).

"8. Itt is left to the diseretion of the priest, if more trentals than one be uppon hande, to intercept the trentul he is saying when some special oceasion happens for remembering the others, soe reparation bee made in due tyme. Alsoe instead of saying one Masse a weeke when death happens, hee is desyred rather to saye, as consequently as hee can, the proportion of Masses allotted to each one respectively 
within one yeare's compasse and then to resume lis manner of saying three Masses a weeke as before, in the next tyme that they come to be due.

"9. Hee is desyred often to request the prayers of such as taste the benefit of this foundation for the doners, and to exhort them att tymes to heare Masses for them and their friends."

An ancient paper contains the following:

"Sixteen Anniversaries.

" Jan. ye 10, dyed Elisabeth Weld, donor's danghter.

" 11 Feb. dyed Richard Shirburn, donor's father.

"4 Mar. dyed Henry Long, donor's chaplain.

"6 Apr. dyed Issabel Shirburne, donor's wyfe.

"16 Ap. dyed Ricl. Shirburne, donor's grandfather.

"16 Ap. dyed Richard Shirburne, donor's eldest son.

"14 May. dyed Anne Shirburne, donor's grandmother.

" 2 June dyed Nichs. Towneley, donor's wyfe's grandfather.

"12 June dyed Elizabeth Shirburne, donor's mother.

" 2 July dyed Bernard Towneley, donor' wyfe's uncle.

"12 July dyed Margaret Ingleby, donor's wyfe's mother.

"16 Aug. dyed Richard Shirburne, the donor.

" 23 Oct. dyed Catherine Ingleby, donor's wyfe's sister.

" 31 Oct. dyed Issabel Towneley, donor's wyfe's grandmother.

“ 27 Nov. dyed Thomas Ingleby, donor's wyfe's father.

"16 Dec. dyed Sir Nicholas Shirburn, donor's youngest son.

"These are all the annyversarys that are to be kept, and the particulars were sent to me by Christopher Tootell, grand vicar, ye 5th 7ber, 1724. Witness, Thomas Brockholes."-Extract from "Records" of the English Province of the Society of Jesus.

Among the vestments belonging to the Chapel are a stole and maniple, embroidered in coloured sills, and with a succession of coats of arms, properly emblazened.

Mr. Weld sends me the following note about these interesting relics:

"The stole and maniple I suppose to have belonged to Eresham Priory; the arms are mostly those of the great Barons and their allies, who warred so long with the crown with varied success until finally 
overthrown at the battle of Evesham, where their great leader, Simon de Montfort, was slain. He was buried at the Priory: his arms are given twice.

"John Abbot, of this Monastery, granted license, 7. Edw. II, to Sir Robt. de Shireburne and Alice his wife, to have a chantry within the oratory at his Manor house of Longton (the residence of the family at that time), so as not to prejudice the rights of the Church at Penwortham, itself under Evesham. The stole and maniple may have come to the Shireburnes $a$ : this time. It is supposed to have been sent to Leagram when that place first came to the possession of the Shireburne family, or when Richard Shireburne, father of Sir Nicholas Shireburne, of Stonyhurst, Bart., endowed the Chapel at Leagram in 1685."

\section{JoHN WELD, J.P.}

Mr. John Weld comes of an ancient and wealthy Catholic family. In 1752, Lengram Hall, along with the rest of the Shireburne property, passed to Edward Weld, Esq., of Lulworth Castle, Dorsetshive. He is well-known as a keon antiquarian, and is an exceedingly intelligent ornithological observer, and contributes articles to various magazines.

For some years Mr. Weld served with the 5th Lancashire Militia, going into camp with then at Aldershot. During recent years failing health has prevented him from taking any nctive part in public affairs. He is a county magistrate, a Catholic, and in politics is, we believe, a follower of the Marquis of Hartington. It is with feelings of tho deepest regret that the writer has to chronicle the death of Mr. Weld, which took place on Norcmber 25th, 1888. Mr. Weld was born in 1813 , and on his father's death, in 1866, sncceeded to the family estate. At his funeral a justly high tribute to his memory was paid by the Bishop of Salford, who spoke of his great intellectual powers in scientific research. Mr. Weld was much esteemed by his tenantry and the people of the district generally.

The Stonyhurst IIrgazine-to the pages of which he often contributed -has the following "In Memeriam" notice of the late Mr. Weld:In Mr. Weld, of Leagram, Stonyhurst has lost another of its old familiar tigures. Not only as an old Stonyhurst boy and a near neighbour, but also as representative of the family to which the College owes so much, he was one who could not but 
attract the attention of the many generations he lived to see, although attention was the last thing he sought. Living at Leagram, the last portion of their old property in this district which the Weld family have retained, in a position, even in these days, with difficulty accessible, he has for many years lived a life of un. common solitude. Those, however, who were privileged to see him at home cau bear wituess to the great activity of mind which supplied him with ample resources for eujoyment ; and the "Stonyhurst Magazine" must on no account omit to record its obligations to one who enriched its pages with so much and such valuable in. formation. His knowledge of the antiquities of the district was probably unmatched, and the store of deeds and documents belonging to the Weld and Shireburn families, which had beeu removed to Leagram, when his grandfather parted with Stonylunrst, had been diligently studied by him and its information arranged and registered. No Roman road, old building, inscriptiou, or church font for miles around was unremarked by him. He was able to point out the localities where flint hatchet, Roman coins, or Saxon weapons had been found or might be looked for. He had also diligently collected the oral traditions of the neighbourhood, and was full of information upon ancient fre-worship, Scaudinavian folk-lore, and the Jacobite risings. The natural history of the district was also familiar to him, and we may in particnlar recall the fact that his notes were the foundation of our recent bird. list. He was an excellent draughtsman, aud his portfolios abound with sketches of the tombs of the Counts of Flanders, notes of foreign travel, old farm houses, manor houses, and churches, birds, mollusca, fungi, and in particular the animals of the shore to which he paid so much attention during his risits to tho sea-side. He also much improved Leagram, of which it is interesting to note that all the fine trees by which it is surrouncled were planted by bis father or himself. In particular he built from his owu designs the beautiful chapel, in the vault beneath which he now lies. As was recorded by the Bishop of Salford in the few words spoken at his funeral, that he had for years made it his rule to recite every day not only the liosary of Our Lady but also that of the Precious Blood, and the character he most resolutely maintainel was that of a staunch and deroted Catholic. Two years ago he was President of the Stonyhurst Association, and the generous gift witl which he marked the close of his office should live in the grateful memory of those who still feel the benefit of it in the boys' libraries. Mr. Weld, who was born in 1513, came to Stony hurst in 1823, and succeeded to the Leagram property in 1S66. He died after a very slort illness on Sunday, November 25th, 1SSs.-R.I.P. 


\section{CHAPTER IX.-GRIMSARGH.}

Origin of name-Lords of the manor-Non-jurors in 1715-The Parish Church-liev, John Cross-List of Vicars: Rev. John Harrison-Rev. R. Grainger-Rev. J. IV. Hull--Rev. W. Pilling-Rev. W. Harrison-Rev. F. D. Pritt-Improved servicesChurch Times-Rev. 'T. H. Davies-Value of living-Rel Scar-The late Colonel Cross-Higher Brockholes Hall-The Elstons-Lower Brockholes Hall-Grimsargh Hall-T'he Dun Cow legend - Hardwick - St. John's College: A successful schoolRev. T. A. Peters - Area of parish-Population-Agricultural Statistics.

Grimsargh is mentioned in "Domesday Bools," but, like Goosnargh, the village probably existed long before the Conquest, as its name would lead us to suppose; the derivation of the word being probably:

"Argh," Hörgr [A.S. hearg; O.H.G. haruc] a heathen place of worship, a sacrificial cairn. The original meaning of the word is, therefore, the altar of Grim, a Scandinavian hero.

In 1338-9, William de Eton held the Fill of Grimsargh by the service of $3 \mathrm{~s}$. a year. The Hoghton family held the Manorial rights of the place for a long time, from whom it passed into the hands of the Cross family-the Lord of the Manor being IVm. Cross, Esq., of Nerreastle- . -on-Tyne, nephew of the Secretary of State for India.

In 1650 the value of Grimsargh was $£ 13$ 6s. 8d.

The tithes of Brockholes belonged to Sir R. Hoghton, and were valued at $£ 10$.

The Commissioners reported that Grimsargh was distant " 3 myles from Preston, after the rate of $5 \frac{1}{2}$ yards to the pole, and 320 poles to the myle."

R. Elston paid 6s. 8d. per ann., and F. Bindlose 4s. per ann. for tithes to the Vicar of Preston.

The non-jurors of 1715 were:-

Paul Charnley, yeoman, freehold estate there and at Elston,"subject to

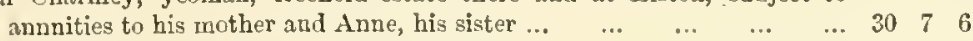

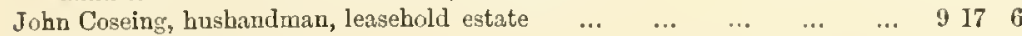
$\begin{array}{llllllllll}\text { Tobert Hummer, miller } & \ldots & \ldots & \ldots & \ldots & \ldots & \ldots & \ldots & \ldots\end{array}$ $\begin{array}{lllllllllll}\text { Kichard Fishwick, calpenter } & \ldots & \ldots & \ldots & \ldots & \ldots & \ldots & \ldots & \ldots\end{array}$ $\begin{array}{llllllllll}\text { G. Clarkson, husbandman } & \ldots & \ldots & \ldots & \ldots & \ldots & \ldots & \ldots & \ldots\end{array}$ James liogerson, yeoman, house there and at Haighton... $\quad \ldots \quad \ldots \quad \ldots$ John Newsham, of Brockhull, 7 houses and 16 acres at Fulwood, and froehold $\begin{array}{lllllllllllll}\text { estate at Whittingham } & \ldots & \ldots & \ldots & \ldots & \ldots & \ldots & \ldots & \ldots & 26 & 15 & 0\end{array}$ 
Gilbert Slater, husbandman, son of Thomas Slater, leasehold, there and at Haighton, part tenanted by Thos. Slater, charge with $£ 20$ to his sister $\begin{array}{ccccc}\text { and } £ 4 \text { to his mother } \ldots & \ldots & \ldots & \ldots & \ldots\end{array} \ldots \ldots$

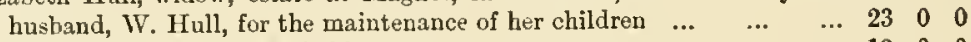

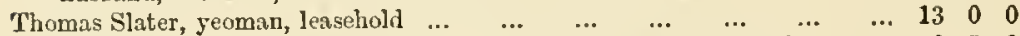
Alice Charnley, of Elston, widow, annuty of $£ 5$ and leasehold land... $\quad \ldots .6 \quad 6 \quad 50$ Ann Charnley, spinster, amount out of land at Elston in possession of Paul $\begin{array}{llllllllllll}\text { Charnley } & \ldots & \ldots & \ldots & \ldots & \ldots & \ldots & \ldots & \ldots & \ldots & \ldots\end{array}$ 5000 Henry Crumaleach, Elston, yeoman, 32 acres in fee tail, charged with $£ 4$ to
his sister, and bequeathed by his father-in-law, John Walmsley, Elston, The Church, which is dedicated to St. Michael, was erected by subscription in 1716 . In 1840 a north aisle and a beautiful chancel were added to the building, at the cost of the Rev. John Cross, brother of the late Colonel Cross, of Red Scar. In 1868-9 the body of the Church was re-built at a cost of $£ 3,000$, which was also defrayed by the Rev. J. Cross. The Church has a very neat and pleasing appearance, and is very well built. The interior is excellent in its proportions, the roof is elaborate and lofty; and the Church affords accommodation for 220 people. On the floor of the Church is a magnificent brass plate. It has a rich, gothic canopy, inlaid with shields and ornamented with allegorical figures, Below are the figures of the late Mr. and Mrs. Cross - the grandparents of the present Mr. Cross-and at the foot there is the following inscription :- " Here lie the remaius of William Cross, Esq., born 24 July, 1771. Died 4th June, 1827. Also the remains of Ellen, lis wife, born in December, 1783. Died 27 January, 1849. 'Their four sons erected this moument." There is an excellent organ in the Church, re-built by the late Colonel Cross.

A brass plate has recently been placed in the Church in memory of the late Col. Cress and Mrs. Cross, by the members of their family.

$$
\text { List of Vicars. }{ }^{1}
$$

1803 Rev. Joln Harrison, M.A.

1823 Rev. Richard Grainger, M.A.

1850 Rev. Joln Wiustanley Hull, M.A.

\footnotetext{
1 I have been unable to ascertain the uames of the Vicars prior to 1803. Neither the lev. J. H. Fawdon, patron of the living, nor tlie late and present
}

Vicars of Grimsargh, possess any records of them. Are the names irrecoverably lost? 


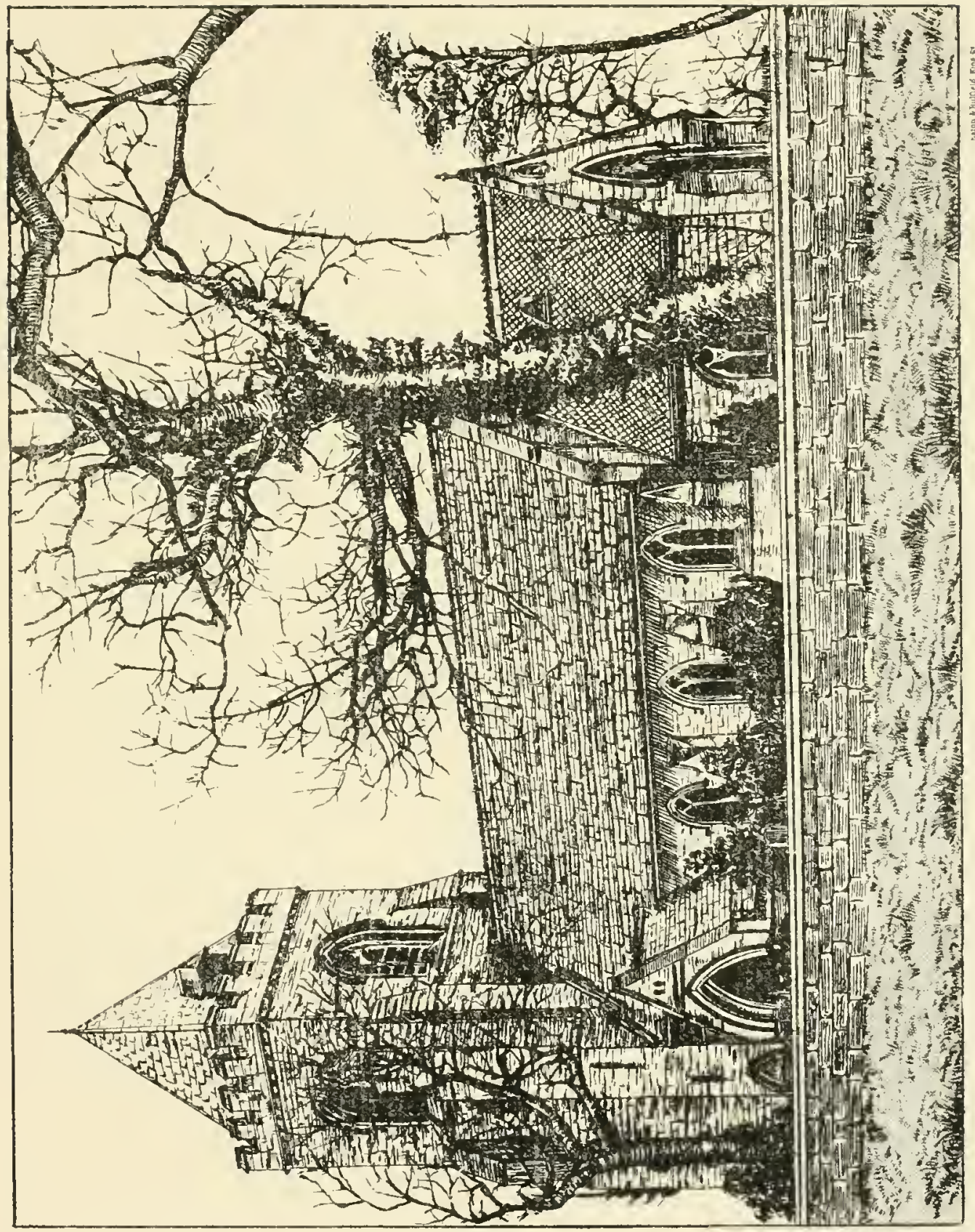



1854 Rev. William Pilling, M.A.

1865 Rev. William Harrison, M.A.

1886 Rev. Francis Drinkall Pritt, M.A.

REV. JOHN HARRISON, M.A.

The Rev. John Harrison was born at Adgarley, Kirby Ireleth, in 1767. His father was a yeoman, and died aged 78 .

In his youth, John Harrison was a tuter in a school at London. His first curacy was in the Island of WaIney; from that place he went to Burnley, as curate under Dr. Whittaker, the historian, at Holme. In 1803 he was appointed Vicar of Grimsargh, also helding an appointment as second master at Preston Grammar School, and was Chaplain at the House of Correction in Preston. In 1803 he married Miss Thompson, of Urswick, and had two children; one the Rev. TVilliam Harrison, M.A., T.C.D., aftertwards Vicar of Grimsargh ; and a daughter, who married John James Myers, Esq., C.E., J.P., twice Mayor of Preston. Mr. Marrison was the author of "The Etymological Enchiridion," published anonymonsly in 1823.

He was a good man, an indefatigable worker, and much esteemed by his parishioners. He died suddenly, of a joplexy, on the 8th July, 1823, while cerrecting the word "subpœna" in the proof sheet of his "Enchiridion." He was 56 years old at the time of his death. His remains were interred at the north side of the Preston Parish Church.

The Rev. William Pilling has kindly sent me the following interesting communication respecting the late Rev. J. Harrison :-

"With reference to the Rev. John Harrison, a very old Grimsargh person told me, seon after my appointment to the living, that the work he was preparing for the press when he died was conpleted by the Rev. Mr. Harris, Incumbent of St. Geerge's Church, Preston; and that the Rev. John Harrison, two Sundays before his death, when walking along the road to Church with the father of the late Colonel Cress, of Red Scar, made this strange remark:-'Another Sunday and then I have done.' This proved true. He took the duty at Grimsargh the following Sunday for the last time."

${ }^{2}$ Perhaps Mr. Harrison was referring to his book. 
REV. RICHARD GRAINGER, M.A.

The Rev. R. Grainger was Incumbent of Grimsargh for 26 years. During his incumbency the Vicarage was built, in 1824-5. He died in 1849 , and is buried in the churchyard at Grimsargh.

REV. JOHN WINSTANLEY HULL, M.A.

The Rev. J. W. Hull was Incumbent of Grimsargh for 3 years. $\mathrm{He}_{\theta}$ was formerly Curate of St. Michaels-on-TWyre. On leaving Grimsargh he was appoiuted Vicar of North Muskham, Notts, which living he still holds.

REV. WILLIAM PILLING, M.A.

The Rer. J. W. Hull was succeeded by the Rev. Wm. Pilling in 1854. Mr. Pilling stayed at Grimsargh 11 years, when in 1865 he was appointed Vicar of Ormesby, Leicestershire. About three years ago he accepted the charge of the new Parish of Ribbleton, near Preston. Mr. Pilling was also Curate of Whalley previous to 1854. Mr. Pilling was an earnest worker when at Grimsargh, and was well-known as an able and popular preacher.

REV. WI. HARRISON, M.A.

"Mr. Harrisou was the son of the late Rev. John Harrison, vicar for 20 years of Grimsargh, who died in 1823. He was educated at the Preston Grammar School, where he became second master, in 1830, and entered as a student in Trinity College, Dublin, in January, 1828, taking his A.B. degree in 1832. He continued his connection with the Grammar School till 1836, when he was ordained by Bishop John Bird Sumner as curate of Peuwortham, 17th July, 1836, being orlained priest on the 30th July, 1837. For a short time he was in charge of St. James' Church, Preston. Ho was appointed head master of Hutton Grammar School in April, 1839, and whilst holding this position, he was engagerl as assistant minister under the late Rev. Robert Harris, at St. George's, Preston. It was during this period that he took his M.A. degree. Leaving Hutton School, an address of regret, signed by 1,421 of the inhabitants of the parish, was presented to him, and was accompanied by a handsome tea and coffee service of plate, upon which was inscribed: 'Presented to the Rev. Wm. Harrison, M.A., by a few of his friends and pupils as a testimonial of their respect and esteem.- 
Hutton, 1851.' A pocket communion service was also presented to him. He was afterwards liceused as curate of Waddington, near Chitheroe, where he remained until 1863. Upon the resignation, in 1865 , of the Rev. Win. Pilling (now of Ribbleton), he received the appointment of incumbent of Grimsargh from the late Ciuon Parr. It will be noticod as somewhat curious that father and son lave held the same living for 20 years. Duriug the interval, the charge was filled by $\mathrm{Mr}$. Grainger 26 years, Mr. Hull three years, Mr. Pilling 11 years. Although Mr. Harrison has not been able to take active duty for the past four years, owing to failing health, he has continued a supervision orer the parisl, and has been assisted for the past two years by the Rev. T. II. Davies, formerly curate of St. Mary's. He was not, as far as we know, the author of any books, preferring rather to devote his attention to parochial work, and to the study of theology and natural science. He was known as a powerful and impressive preacher, and many of his sermons, though preached years ago, are remembered by those who heard them. Mr. Harrisou died on Oct. 24, 1885, aged 76. A large and sympathetic gathering of friends followed his remains to the grave at Grimsargh."-Preston Chronicle, October 31st, 1885.

RET. F. D. PRITT, M.A.

The Rev. Francis D. Pritt was appointed Vicar of Grimsargh in 1886, on the death of the Rev. W. Harrison, who held the living for 20 years, and who is buried in the churchyard of Grimsargh, aloug with his father, the Rev. Joln Marrison. Mr. Pritt is a middle-sized man, in the prime of life. At the first glance you can tell he is no ordinary man. With a somewhat grave deportment and a merry twinkle of the eye, he wears an air of determination, which bodes ill for any opponent of his. He is a High Churchman, as can be gathered from the extract given below. As a preacher, Mr. Pritt is earnest, but quiet and subdued. His sermons are scholarly, practical, and suited to the intelligence of his hearers. After very careful inquiries we believe the extract given below conveys a just impression of the change which has taken place in Grimsargh during the last three years. The ordinary Sunday services being well attended, the collections good, and the singing truly admirable-clear signs of the approbation of the Grimsargh Church-people. 
"st. MichaEL's, GRIMSARGH, NeAR PRESTON.

"Some of our Lancashire reader's will be interested in learning of the progress that Catholic teaching is making in this district. Two years ago, before the coming of the present vicar, the Rev. Francis D. Pritt, the services were of the severely Low type, but Mr. Pritt has shown his clerical neiglibours, who seemed somewhat sceptical as to the receptiveness of the hard-headed North Laucashire farmer in matters of Catholic doctrine and Ritual, how much may be done by sheer doggedness. The progress that has been made may be gathered from the following list of services at the church dedication and harvest festivals observed on Saturday and Sunday, September 29th and 30th: Saturday: 8 a.m., Holy Communion; 8 p.m., Evensong. Snnday : 8 a.m., Holy Communion; 10-33, Matins and Celebration (Missa Coelestis, A. H. Brown); 1st Evensoug and Sermon, 3 p.m.; 2nd Evensong and Sermon, 7 p.m. The solemn Te Deum was sung befor $\theta$ the close of the seven o'clock service. The music used at this church is Gregorian. The mixed chalice, E.P., altar lights, ablutions, coloured stoles, ar $\theta$ also used. All the services were well attended, the church being crowded in the afternoon and evening. Mr. Pritt, after some little resistance, has succeeded in winning over the bulk of his people, and he has the satisfaction of seeing that the ministrations of the church are now very acceptable. Mr. Pritt was for seven years vicar of Coldhurst, Oldham, where now the fruits of his sound Catholic teaching are to be found." - Church Times.

The late Curate-in-charge, the Rev. T. H. Davies, in a letter to the Church Times, says:-"The services from early in 1884 until June, 1886, were of a distinctly musical character, and the teaching from the pulpit was distinctly Anglicnn." He also gives some rather striking figures of the number of communicants aud candidates for confirmation, in order to prove "that church work was not neglected" during his curacy.

The living is in the gift of the Vicar of Prestou, and is returued at $£ 117$ per annum, with a residence.

There is a small school close to the church, with an average attendance of about 40 .

There are no other places of worship in the village. 
ReD SCaF.

Red Scar is most charmingly situated on the banks of the Ribble. The river, in its course from Ribchester to Preston, takes a sweep to the north-west, and then, after flowing for nearly a mile, takes a sweep to the south-east, thus forming the shape of a horse-shoe.

The house is built in the late Jacobean style of architecture. When the late Colonel Cross was alive there were two observatories in the grounds, for that gentlemau was no mean astronomer. Wm. Cross, Esq., the owner of the estate, has lately let the house to IV. Leventon, Esq.

\section{Higher Brockholes Hall.}

Higher Brockholes Hall was the abode of a family of some distinction among the Lancashire gentry. It is in rather a dilapidated state, but jou can still form some ilea of its former stately proportions. On the front of the hall is carved the following:-

$$
\text { R. } 1643 \text {. }
$$

The initials are those of Richard and Ann Elston. The Elston family oceupied Higher Brockholes Hall from 1387 to 1662, from whom it passed into the hands of the Moreans, and then to the Winckleys, in in whose possession it remained till lately. ${ }^{1}$

\section{Lower Brochholes Hali.}

Lower Brockholes Hall is of even greater antiquity than Higher Brockholes Hall. It bears the armorial bearings and the initials E. \& F. B. of its builder, and the date of its erection, 1634. Baines says, "Over the principal door are carved in stone the arms of the Brockholeses in alto relievo, three bucks [brocks] or badgers." But, according to MIr. W. Dobson, Baines must have been wrongly in formed, for the arms are not those of the Brockholes family at all. They are the arms of Fraucis Bindloss, son of Sir Francis Bindloss.

For a time Lower Brockholes Hall was the seat of the Brockholeses, then of the Singletons till 1564, by whom it was sold to Sir John Southwortl, of Samlesbury. Edmund Breres, of Preston, was the

\footnotetext{
1 In the Familice Lancastriensis a pedigree of the Elstons is given from 1371 .

1667, which I am obliged to omit from want of space.
} 
next owner, from whom it passed to Sir Robert Bindloss, of Borwick Hall. Ultimately it bocame the property of the Winckleys, whose descendant, Lady Shelley, long owned it.

Grimsatigh HaLL.

Grimsargh Hall is little more thau 100 years old, being built in 1773. Over the front door is a large bone; the "old rib" it is called, and said to be that of a cow whose history is related in the following paragraph. Hardwick says the bone is suggestive of something "very like a whale.".

Mr. Charles Hardwick, in "Traditions, Superstitions, and Folk Lore," gives the following account of the Grimsargh Dun Cow :-

There is a tradition, in the neighbourhood of Grimsargh, to the effect that during some drought, " in the olden time," a gigantic dun cow appeaced, and gave an almost unlimited supply of milk, which saved the inhabitants from death. An old womanof the witch fraternity, I suspect-however, with the view to obtain from the beast more than the usual number of pailfulls, milked the cow with a sieve, riddle, or colander, which, of course, never became full, as the precious liquid passed through the orifices into a vessel below. The tradition adds that the cow either died of grief of detecting the imposture, or from aheer exhaustion, I forget which. A locality is still pointed out, named "Cow Hill," where gossips aver that, in relatively recent times, the huge bones of the said cow were disinterred.

Hardwick goes ou to point out that, as in all these traditions, there is a semblance of truth. It is not improbable that at some early period the remains of the huge extinct ox, the bos primigenius, or even the elephas primigenius, or fossil marnmoth, may have been exhumed in this neighbourhood. "Some such discovery," he concludes, "grafted upon the ancient Aryan tradition respecting the heavenly cows, or rain-giving clouds, opportunely rescuing the parched vegetation from premature decay, might very easily eventuate in such a tradition as the one current in Grimsargh at the present day."

\section{St. Johr's College.}

One of the few high-class schools in the district is St. John's College, Grimsargh, the old residence of the Chadwick family, then known as "The Hermitage." The College is prettily situated a little way from the high road to Preston, and close to Grimsargh Station. A better idea, than any descriptive sketch can give, of the College exterior and grounds can be obtained from the view of the buildings which fronts this page. The school is fitted up with the most modern improve- 


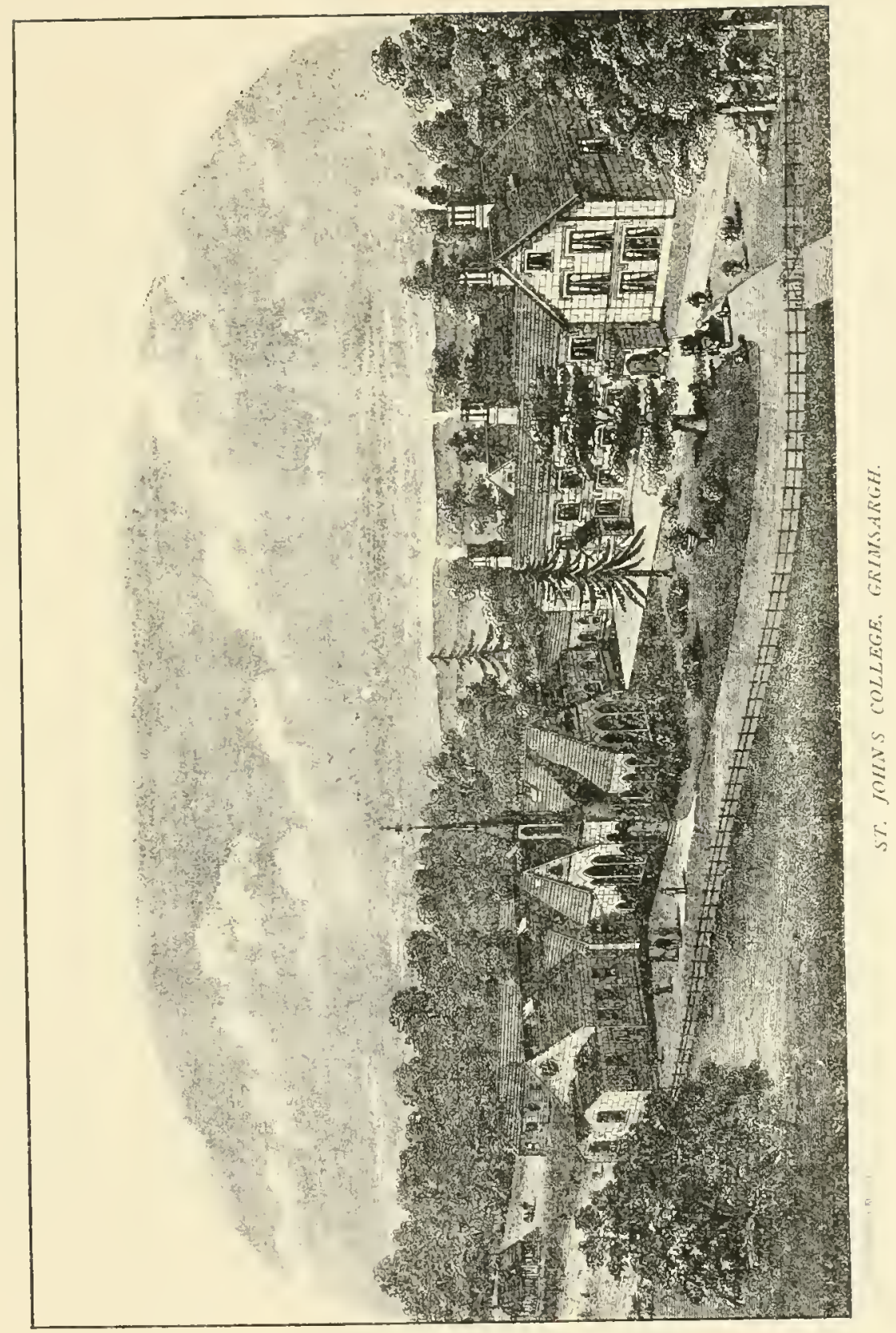



ments, including airy and pleasant class-rooms, a large sminming bath, and gymnasium, besides cricket and football fields of nine acres in extent. There is also a beautiful chapel attached to the school, which is licensed by the Bishop. We do not suppose that in any school in England better provision is made for the bodily comforts of the boys than at St. John's College-a matter, though of such vital importance to growing yonths, which is often neglected. "Mens suna in corpore sano" is evidently the motto of the Rev. T. Abbott Peters, M.A., the respected Principal, and Mrs. Peters. The sucesses attained by the pupils at the various Universities, the Army, and Civil Service, prove conclusively that every attention is paic by the masters of the school to teveluping the mental faculties of the students. A list of these successes during the last few years would fill many pages of this book. A striking proof of the fame which the College has attained is afforded by the number of pupils, which is now upwards of $100 . W_{\theta}$ may add that the sanitary condition of the school is excellent.

A brief sketch of the Rev. T. A. Peters is necessary, as it affords a striking instance of what "self-help" can accomplish. Born of humble parents at Preston, $M{ }^{1}$. Peters is in an eminent degreo a self-made man. In early manhood he starterl a night school in Alston, and becoming well known for his training abilities, he was soon enabled to build his first school, Alston College, in 1854. The venture proved a great success entirely through the Principal's untiring energy and perseverance. In $1873 \mathrm{Mr}$. Peters purchased "The Hermitage," which he converted into an extremely compact school. The greatest possible praise is due to Mr. Peters, who has been ably seconded by his wife. Both of them are beloved by their pupils, and are also highly respected by all their neighbours.

The village of Grimsargh is three miles S.S.W. of Longridge. In the village is a station on the Prestou and Longridge railway. The steam tram to Whittingham Asylum starts from Grimsargh; but costly as the venture has proved to the county ratepayers, the line is not allowed to be utilized by the public for local traffic-a state of affairs which doubtless the County Council will at once restify. 
[CH.sP. 9.

The area of the parish of Grimsargh is 2,879 acres; Elston 934 acres; Grimsargh-with-Brockholes, 1,945 acres. The land is of a high order. The principal landowner is W. Cross, Esq., of Red Scar and Neweastleupon-Tyne He owns 828 acres. The population returns for the present century are:-1801-262; $1811-279 ; 1821-343 ; 1831-$ $310 ; 1841-331 ; 1851-360 ; 1861-301 ; 1871-410 ; 1881-361$.

Agricultural Statistics.

Number of Statute Acres-*

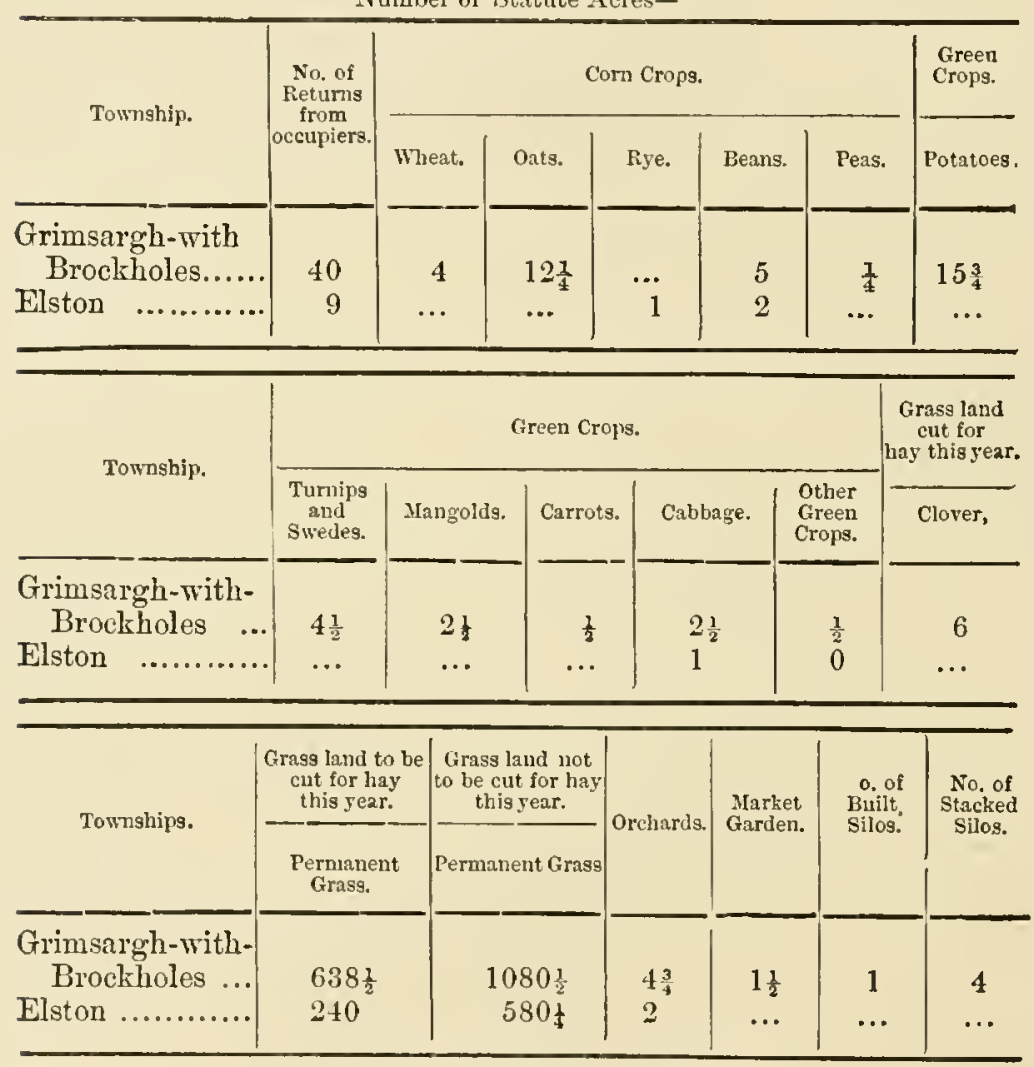

*Quantities less than 1 -acre not included. 
Live Stocik on 4til June, 1886.

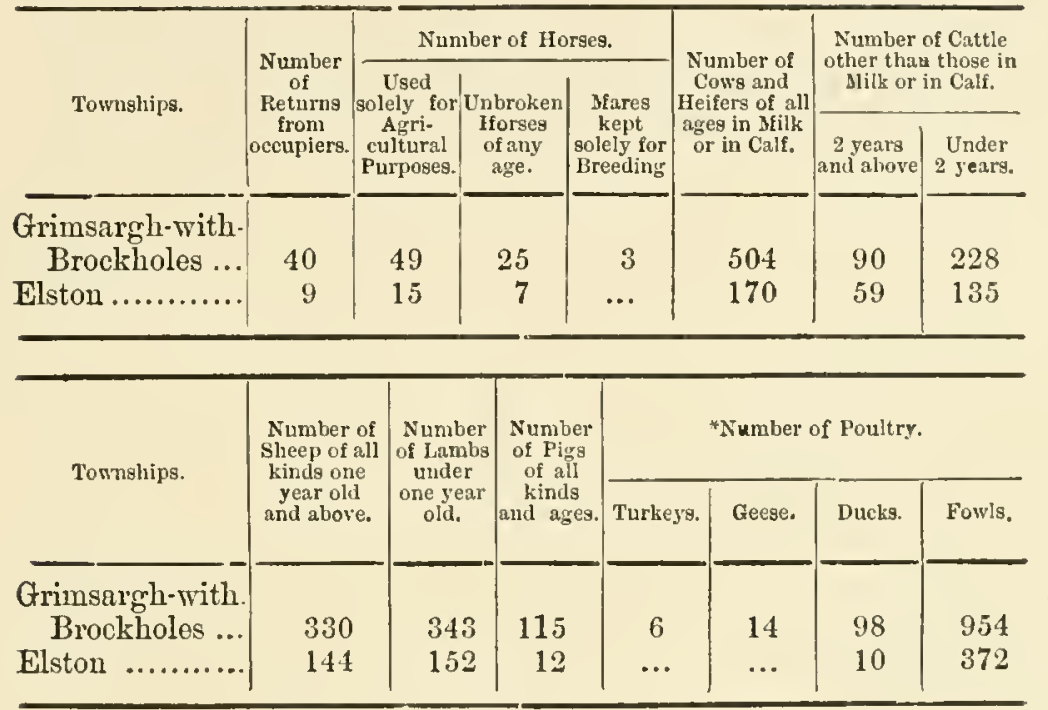

"Probably (.)nsiderably under the numbers. 


\section{CHAPTER X.-IVHITECHAPEL.}

Population-Situation-Antiquity of Church-Church bell, 1551-Sir H. de HoghtonValue of living, $1650 ; 1700$-Foundation of School, 1705-Church enlarged, 1720; 1753-Ancient Sun dial-List of Vicars-Rev. E. D. Bannister-Rev. T. Saul : Non-residence-Correspondence, 1810-12-Only 24 perws-Church unconsecratedNo marriages or burials-Petition of inhabitants-Ietter from Bishop SparkeBishop's monition-Resignation of MIr. Saul-Rev. H. Shuttleworth : Patron of living-Correspondence.

Trie Parish of Whitechapel was formerly occupied by a colony of handloom weavers, but they have loug since left the place, and to-day it is only a rather poor agricultural district, the land being mostly fell land, and much exposed to the weather. The population was in 1831, $928 ; 1861,646$; and in $1881,561$.

It is situated on the slopes of Beacon Fell, and is about $4 \frac{1}{2}$ miles from Longridge, in a westerly direction.

The Chureh at Whitechapel, or Threlfall Chapel as it was sometimes called from the fact of its being situated in the Threlfall Tything, is of considerable antiquity. The very diminutive size of the original structure ( 27 feet by 13 feet) would warrant the assumption that it was first erected as a private oratory.

A copy of a document now in the Church chest is given by Col. Fishwick in his History of Goosnargh, from which it appears that a bell belonging to the Chapel was taken by Alexander Houghton in 1581, who promised to replace it when required to do so. In 1728 an application was made to Sir Henry de Hoghton for the bell, who, instead of restoring it, stated that "Queen Elizabeth had given a bond to his ancestors for $£ 50$, which was not worth anything at all, and he had no tenants in Goosnargh." He, however, gave 10s. towards the cost of a new bell.

In 1650 it was reported that there was only $£ 50$ allowed to $\mathbf{M r}$. Sherbourne, the minister there, "the chappelry consisting of four score ffameleys at the least," the inhabitants desire it may be made a parish and competent maintenance allowed.

Bishop Gastrell, writing at the beginning of the 18 th century, states "that Whitechapel, within Goosenargh, certified that nothing at all belongs to it, and is servied now and then only out of charity at ye request of ye people." 
In 1705 the school was founder by William Lancaster, linen weaver, of Groosuargh, and one Higham gave $£ 60$ to the same object conditionally ou tho minister acting also as schoolmaster, which was done until 1820.

In 1720 and 1756 the Church was enlarged, ehiefly by grants from Queen Anno's Bounty, by William Stratford, LL.D., and by various small donations, amounting in all to $£ 400$. In 1818 the Chapel was again enlarged. In 1855 land was bought on which to build a parsonage; and at this time marriages were allowed to be solemnized.

The Church itself (dedicated to St. James) is a plain, barnlike looking building, and bears wo date or inscription, although some of the pews are dated 1739. A very handsome carved oak communion table and rails were presented by Mr. Benn, the late vicar, who himself executed the carving.

In the chmrchyard is a sun-dial beariug the following legend :"Lat. $53^{\circ} 40$ '. Tive memor lethe figit hora. The Rev. Mr. Penny, minr. ; Henry Porter, of Westfield, fecit and sculpt. 1745."

A movement started a year ago has resulted in the restoration of the old Church, which has been done in a very efficient manner. ${ }^{1}$

There is a very efficient school at Whitechapel, with an average attendance of 57 .

Curates of Whitechapel.

A list of the Curates of Whitechapel is given by Fishwick as under :-
1650
Rev. Mr. Sherbourn.
1720
Rev. Mr. Birket‘.
$17-64$
Rev. John Penny.
$1764-74$
Rev. James Farrer.
$1774-96$
Rev. Benjamin Wright.
1796-1808
Rev. Thomas Stephenson.
1808-1813
Rev. Thomas Saul, M.A.
1813-1815 Rev. Philip ${ }^{2}$ Gerard Slatter, M.A.
1815-1836 Rev. James Radcliffe, M.A.
1836-1873 Rev. Thomas Benv.
1873
Rev. Edmund Dawson Bannister, M.A.

${ }^{1} £ 270$ is still required to meet the cost of the alterations.

${ }^{2}$ Phipps. 
The living of Whitechapel is in the gift of the Dean and Chapter, Christ Church, Oxford, and is returned at $\$ 250$ per annum.

REY. E. D. BANNISTER, M.A.

The Rev. Edmund Dawson Bampister M,A., the present Vicar of Whitechapel, is, without doubt, the best preacher in any of the country districts about Longridge. A tall, well-made, clean-shaved man, of about fifty, he has therenghly familiarised himself with agricultural matters. His sermons savour distinctly of the soil. Many of his allusions are drawn from the land and the farm, and are of a very practical nature, thus impressing his hearers more than usual. It seems a pity that a parson with such qualities as $\mathbf{M}[r$. Bannister should be allowed to wear himself away in a small and obscure hamlet like Whitechapel. $\mathrm{He}$ is very popular amongst his people, and is, we believe, an energetic worker.

REV. T. SAUL, M.A.

Recently there came inte my possession some very interesting documents relating to the dispute between the Rev. T. Saul and his parishioners, extracts from which I publish in order that some light may be thrown upon Church questions at Whitchapel during the early part of the present century.

I should preface the following letter by saying that Mr. Srul's parishioners complained of his non-residence, and the mattor was placed by them in the hands of $\mathrm{Wm}$. Cress, seliciter and prothonotary, of Preston. Writing to Mr. Wm. Cross, from Lancaster, 20 Nor. 1810, Mr. Saul says:-" My flock is vory small in number, consisting of nene but pew proprieter's, and there are only about 24 pews, therefore I consider the petition (complaining to the Bislıp) so numeronsly signed must be signed by many per'sons who have ne interest in White Chapel. However, they know my intention of residing when I can meet with a decent house, either to rent or purchase; and in the meantime $I$ have a resident curate whe takes the duty when $I$ do not attend. I, of course, do not know the statements made in the petition, lut if you rely upon the assertions of Mr. M., or even Mr. S., you may perhaps net be very correct. 
"White Chapel is an unconsecrated Chapel attached to no peculiar district, the whole income of which arises from purchases made by the Govs. of Queen Anne's By. since 1720, and I conceive the minister has no duty to perform but Sumlay duty. I cannot administer the Sacrament at IV. C. All my flock atteud the Sact. at Goosuargh, and therefore the minn. at Goosnargh must attend those who from sickness cannot attend him. I neither marry nor bury, ${ }^{2}$ and can baptise only with the permission of the minr. of Gooswargh; of suoh baptisms I have no register, but the minr. of Goosuargh orders and poys my clerk for sending him the names, aud for recoiving the fees for him. I receive no dues on any occasion. I have been thus particular, being confident that yon will not be author of a petition wch. shall contain any statement but what is strictly true.

"Believe me, with great esteem,

"Your much obliged servant,

"Thonas S.AUL.

"P.S.-I believe the true object of the prime movers of this business is to drive me away (knowing the difficulty of procuring a comfortable house) in hopes that my successor may be willing to teach a school of 50 or 70 children for $£ 25$ a year, which I declime, and for this sole reason $I$ am persuaded he has kept the school vacant since May last, contraly to the wishes of his neighbours."

Having been reminded that a house had been at his disposal, Mr. Saul writing to Mr. Wm. Cross on 3 Dec., 1810, replies that the honse, which was part of the farm purchased by the bounty money, had been let for 7 or even 8 years, as he did not care to farm the land like his two predecessors.

In a postscript Mr. Saul adds, "Perhaps your Chients may inform you what was done with the Money, the Interest of which was to be praid to the Minister of Whitechapel, if he wonld visit the sick and baptize in the higher part of Goosnargh." Someone, perhaps Mr. Cross, has

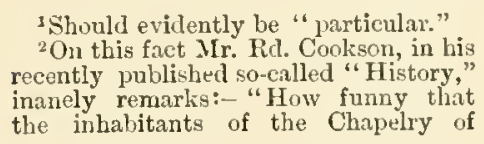
the now called Church of Whitechapel
should have been obliged to emigrate to
get wed." Very funny I am sure Mr.
cookson would have found it had he
lived in Whitechapel them. 
endorsed this letter with the follorring reply: "This money, together with a sum left by one Higham, was laid ont along with Queen Anne's Bounty in the purchase of the Hill House estate, near the Chapel."

From the Petition sent to the Bishop of Chester, Dr. Sparke, I gather the following-That the Chapel was worth $£ 100$ or upwards : the School, now vacant, was worth $£ 45$ per annum. The dwellinghouse attached to the living was within half-a-mile of the Chapel, had been occupied by the last resident Curate, and was in fair condition. There was duty every Sunday morning and afternoon except 4 days in the year, when the Curate usually assisted at the Sacrament at Goosnargh Church.

No funerals or marriages, only baptisms to perform. Part of the land bought with money left for the purpose by one Beesley, on condition that the Curate should reside in the township of Goosnargh, and visit the sick at the higher end of that township. The petitioners further go on to say that the Inhabitants contemplate enlarging the Clapel, and have applied to have the Sacrament administered there, as the Chapel is $2 \frac{1}{2}$ miles from Goosnargh Church. They conclude by stating that not only has Mr. Saul refused to reside in the parish, but has also engaged a Curate, contrary to the express wish of tho people, and they pray for the Bishop's assistance and interference.

After some delay the following reply was received from the Bishop of Chester :-

18, Berners Street, May 27, 1811.

Sir,-Iu consequence of your former letter I have had some correspondence with Mr. Saul npon the subject of his residence at White Chapel, in the course of which he expressed a wish to be allowed time to look out for some other house in the Cbapelry, or (in the event of his not meeting with one), to euable him to put the present Housc into such a state that it may be fit fur his residence. - With this request I have complied.

I am, Sir,

Your obedient servant,

B. Chester.

The people in further communications stated that Mr. Saul, though resident at Lancaster, was Curate of a place in Yorkshire, as well as Curate of Whitechapel, and they pressed for his lordship's admonition.

Mr. Saul, continuing his correspondence with Mr. Cross, says, in a letter of July 17th, 181l, "that the Bishop offers me his License of non- 
residence provided I reside at my Chapel in Yorkshire," and conclndes hy stating that "althongh I consider myself subject to Ecclesiastical Jurisdiction, I do not think that the Minister of Whitechapel is subject to the penalties of the Residence Act, being an unconsecrated Chapel."

On September 24th, 1811, the Bishop of Chester wrote to say that he thought Mr. Saul ought not to be forced to enter a house where he conlil not be properly acommodated. If he refused to take a conrenient house, his lordship would not be inclined to protect him from now-residence. In October, 1811, Jolnn Fisher took a house for Mr. Saul, belonging to B. Gough, about a mile from the Chapel, and then occupied by Hugl Thomas the gnager. This house seerns to have been a good one, as it had a kitchen, parlour, and pantry on the ground floor, with 4 bedrooms above, with a garden and orchard, and 2 fields containing about 5 acres of very good land, at a rental of 30 gnineas, for a term to last as long as the life of the owner. On Jauuary 26th, 1812, the Bishop again wrote to Mr. Cross saying that if the house chosen was fit for Mr. Saul, he should cortainly join with the parishioners in reqniring Mr. Saul to reside upon his Benefice.

He then refers to a case which lie characterizes as "of the very worst description." It is that of one Ashworth, the perpetual Curate of Newton, near Manchester, who is just released from three years, imprisonment at Lancaster, in consequence of a prosecution against him.

The scene now draws to its natural conclusion, as on the 28th March, 1812, Mr. Saul writes to Mr. Cross as follows:- "An occurrence may" probably take placo in a fow weeks which will terminate our differences. I will not conceal from you that I have received notice of the Bishop's Monition being about to be issued."

On the 2nd of April, Mrr. Saul writes to MIr. Cross: "I propose to resign Whitechapel at Michaelmas or earlier if the Curate can otherwise provide a situation for himself.-Yours, etc., T. SAUL."

Mr. Saul left Whitechapel in 1812. Fishwick says 1813.

Some correspondence took place between the parishioners (for whom Mr. Cross again acted), and the Rev. Humphrey Shuttleworth, M.A., 
the patron of the living, relative to the appointment of Mr. Saul's successor. So interesting are Mr. Shuttleworth's replies that I have thought it desirable to print them verbatim.

There is no date on the letters, but probably they were written early in 1812. Several portions are quite illegible.

The first letter is as follows:- "Allow me to say that nothing in my estimation can exceed the candour and liberality exhibited in your late several notes with which I have been favoured. As to the interest implied or the right of . . . on, . . . that can scarcely be supposed to concern one who is arrived at the age of labor and sorrow, but chiefly on behalf of the right of a . . . . . . . another circumstance I may now subjoin which would not have occasioned a remark, but accidentally - that a candidate for a Benefice may (to . . the point) undertake the teaching of a School. This office I never intended to annex as a condition, as I would do to others as they should to myself, but I mean that if possible, without an oblique reflection on a $\mathbf{M r}$. W[ilkinso]n or any particular candidate, that, to obtain the appointment to a Benefice, he may promise to turn Pedagogue, and afterwards it is very easy to bring forward his reasons for declining. To be the more particular . . . . Mr. Harrison, C. of Groosnargh-in that instance-I only wished to offer the cure to a resident Minister, the late... Mr. Cowper having been exempt as a pluralist and C. of Balderstone. But as I meant at that time to compliment our then Diocesan (now of St. Asaph) with the nomination ex... . my intention as to a resident Minister, at the same time having said that the inhabitants would like him wo less for teaching a School. The Bishop told me that he could reccomend one (said Mr. H- $-n$ ), who would both reside and teach a School. Whether Mr. H-n asked for Cleaver's Translation or not is best known to himself, but he has long since left Goosnargh and rosides and teaches School in Preston. Moreover, a Mr. Wilson, C. of Chipping, caller on me in the name of Mr. Cross, as a candidate for WV.C. adding (after I had given my opinion of the scheme of teaching), that he would not himself promise to continue on that office. My auswer was a fortiori, that at the present moment it was on the choice of another person, though I have not much reason to think that it will be accepted. 
"In that caso it wero superfluous to say that our late Diocesan, Dr. May, on behalf of Mr. Stephenson, who applied for his consent to lold Lund-cum-Kirkham, observed that if the patron chose to nominate him to both Whitechapel aud Lund, he could see no objection, lout he is not the person alluded to for the present momt.

"Dear Sir, believe me Your faithful and obedient servant, " Humphrey Shuttheworth."

The socond letter from the Rov. H. Shuttleworth is dated April 8th, [1812]. In it he says to Mr. Cross:- "I must not omit my" sincere thanks, on the first opportunity, for your kind and well directed attention to the disagreeable subject then in question. You might at the same time be assured that I should readily avail myself of any opportunity of forwarding your proposed plans on a subsequent occasion, were it not for several almost insuperable obstacles. In the first place it will be near six months before Mr. Saul will abdicate. Mr. Wilkinson, you may possibly remember, was objected to by the very man who undertakes to carry everything his own way. Ho said in your presence that $\mathrm{Mr}$. W- $\longrightarrow$ was disapproved of, before he had been tried. He arrived at Whitechapel on a Friday, and the very next day it was that Miller came to signify their disapprobation of him as Curato there. I had been told that the plan was to tire out M[r. Saul, and then they would find a man who would be their schoolmaster, etc., as they liked. All this in defiance of the Incumbent pro tempore, and of the Patron who was to nominate. In the next place, it is a well-known maxim, that a solicitation from inhabitants at large must be an immediate obstacle. One more application of that nature, if complied with, would be almost a standing precedent in future. Mr. W- $\mathrm{n}$ has no claim to the succession on account of the date of his services, and there are several Curates under the same Patronage who might think themselves aggrieved if passed over without the offer of an exchange. To say no more at present, I have to apologise for a small undesigned inadvertency-having returned your note, together with the other papers shown to me yesterday by the Churchwarden from Whitechapel-but I think the tenor of it was no more than is already supposed in that place. There is at all events sufficient 
time for possible contingencies, but at present I wish to stand clear of the charge of having given grounds for expectation to those who have so little claim.

"Believe me, Dear Sir, your much obliged and very obedient

"Wm. Cross, Esq.

"H. Shuttlerworth."1

What was probably a reply to these, or other notes not in my possession, was sent to Mr. Shuttleworth from Whitechapel, by Mr. Cross:- "The Churchwarden is now with me for the first time since I received your letter, and he begs me to assure you on the part of the Parishioners of this Chapeliry, that they have not the least wish to interfere with your free presentation, nor to dictate in whose favour it should be exercised. But they wish me to convey to you in the most respectful manner their regard that you would have the goodness to appoint a Curate who will himself reside among them. With respect to Mr. Wilkinson, I understand that Mr. Saul recommended him to apply to you, and the parishioners thought it but due to him to testify their approval of him during his residence among them; and they had no wish whatever to assume any undue influence upon the Patron."

Such is the story of a successful attempt to force a non-resident pluratist clergyman either to reside among his people or to resign. But little mention is made of this dispute in Fishwick's "Goosnargh." Probably he knew kittle about it.

I shall be very glad to show these letters to the authorities at Whitechapel, and, if desired, will give them to the Church to be put along with the other historical papers relating to Whitechapel.

${ }^{1}$ The Rev. Humphrey Shuttleworth, M.A., was sometime Vicar of Preston. He was one of the preachers in-ordinary to the King; a man of truly singular and eccentric habits, but of a generous and charitable disposition. He died Aug. 14th, 1812, aged 76, and was in- terred in the Parish Church of Kirkham. He wrote a work on polemics, entitled, "Iectures on the Creed of Pope Pius IV th, "together with many miscellaneous tracts against the growth of popery in these parts. - Whittle---History of Preston. 
CHAPTER XI-GOOSNARGH.

Fiwhwick's Goosnargh-Cookson's Goosuargh-Origin of name-Roman roads-Domesday book-Lords of the manor-The De Hoghtons - T'he Catteralls-ArricultureLandowners-Agricultural statistics - Cakes and roads - The "village" of Goosnargh -E. Kirk on the "Nook"-Parish Church-Tablets-Value of living-Vicars Rev. W. Shilleto-Rev. C. O. Gordon: "An amateur Napoleon"-The Hill Catholic Cluurch-List of Priests - Decline of Catholicism-Rev. MI. BrierleyDean House Chapel-Newhouse Chapel: List of Priests-Mr. Gillow on the Church-Tiev. John Carter-Canon Gillow-A characteristic Church ParsonIndependent Church : List of Ministers-Rev. J. Hargreaves--The sworn menLocal celebrities: Rev. W. Mtarsden-Rev. G. Beesley-Rev. E. Clarkson-Rev. J. Clarkson-Rev. R. Arrowsmith-Henry Kirk-Wdward Kirk-R. CooksonPeter Whittle - Whittingham Asylum-Goosnargh Hospital-Old halls-Dun Cow Fib Farm- -St. Anne's IVell -Inglewhite green and cross-Manufactures-AreaPopulation.

I do not intend to enter at any length into the history of Goosnargh, as two histories-or rather only one, in reality-liave already been published of this famous agricultural district. I say only one history really, because Mr. R. Cooksou's Goosnargh, Past and Present, can hardly be called anything but a "collection." " Fishwick's History of Goosnargh, although strikingly incomplete, is, as must be well-known, not only interesting, but also very reliable. I am the more confirmed in my iutentions by the fact that Col. Fishwick has iuformed me that it is extremely probable a second edition of his history will before long be published.

This chapter, then, will deal very briefly with the history of the Church, the sworn men, aud the old families, for a full account of which I must refer the reader to Fishwick's work. I shall, however, give what information I can about the Catholic and Nouconformist Churches and other matters, about which Fishwick says extremely little.

No mention of Ooosnargh is made before the time of William the Conqueror, but most likely the village existed long before this, as the name would lead us to suppose. Fishwick 'says: "Most antiquaries agree that it is a compound of the two words 'argh' or 'arf' the Swedish for a ploughed field, and goosen the old Saxon plural of Goose. The original meaning of the word is therefore Goosefield or Goosegreen."

${ }^{1}$ I notice that, although Mr. Rd. Cookson quotes a little from Fishwick, he makes no acknowledgroent of the

graceful compliments paid to him in the preface of his "History of Goosuargh" -rather a strange omission. 
But the best nodern authorities give an altogether different derivation of the word Goosnargh. The Rov. J. Davies, Monsignor Gradwell, and other writers, ${ }^{1}$ say that the word is derived from the name of a Scandinavian hero, and from the A.S. hearb, O.H.G. haru, and old Norse hörgr. The following learned derivation of the latter part of the word "Goosnargh" will be useful: "Horgr [A.S. hearg: O.G.H. haruc] a heathen place of worship. Distinction is to be made between hof (temple) and horg; the hof was a house of timber, whereas the horg was an altar of stone erected on high places, or a sacrificial caim (like haugr) built in the open air, and without images, for the horg itself was to be stained with the blood of the sacrifice; hence such phrases as to 'break' the horg, but to 'burn' the temple."

The true meaning, then, of the word Goosnargh appear to be "the Sacrificial Cairn of an old hero."

As will be seen from the map on which the course the Roman roads took is traced, the road from Ribchester to Lancaster, after passing the river Loud, ran for three miles through Goosnargh, crossed over Beacon Fell on the Eastern side, and then dipped down to the river Brock, passing close by Windy Arbour.

Mr. Cookson, in his Goosnargh, Past and Present, states that there are no Roman roads passing through Goosnargh, a statement quite erroneous, as may be seen from the map of the district on which the Roman roads are traced.

In the Domesday Book, Goosnargh (Gusanarghe), had one carucate ratable to the gelt, Whittingham (Witingeham), Nowsham ${ }^{3}$ (Neuheuse), two carucates. There must have been a great deal of forest and morass in the district at the timo.

\footnotetext{
${ }^{1}$ Both Professor Blackie and Dr. Taylor fight shy (apparently), of tackling the derivation of "argh"

${ }_{2}^{2}$ Icclandic-English Dictionary. - R Cleasby and G. Vigfusson. Oxford, 1874 .

${ }^{3}$ The derivation of Whittingham and Newsham appears to be: Hain, Heim, Hjem, Heim (Teut. \& Scand.', a home or family residence; literally, a place of shelter, from heimen, Ger. (to cover), hama, A.S. (a covering), cognate with
}

the Greek "heima ;" and Witing, probahly the name of a Saxon clan, or a Scandinarian hero. The meaning of Whittingham is, then, the bome of the Witings.

The meaning of Newsham appears to be "the new home" from Ger. Neu, cognate with the Lat. Novus, and the Greek $N$ cos.

Dr. 'l'aylor's observations on the suffix " ham" are extremely interesting. 
Baines says the first Lords of Goosnargh bore the same name as the township: as one of them, Robert de Goosnargh, was living in tho 12th century, and left a danghter, who had married Hugh de Mytton, who was living in 1205-6. Probably the last of the family was Alexander Gosenar who died previous to 156t-65 leaving two daughters. Since then the name has wholly disappeared from the distriet. The next Lords of the Manor were the Hoghtons and the Catteralls, as we gather from the following documents :

Adam de Hoghton, Knt., and his parceners hold the manor of Gosenarghe, which is one and a half carve, which makes the fourth part and the eirhth yart of one knight's fee, whereof Richard Botiller and William de Cliffeton hold the sixth part, the aforesaid Adam a third part and fifth part, by a charter of the Lord E., the late Earl, for the tenth part of a fee; Nicholas de Longeforde a third part of a fifth part, and lichard Katerall a third part of a fifth part, paying yearly at the four terms as above twelve shillings, and sent to the county and wapentake, which may be [due] by fealty and acknowledgement of the aforesail Sir Adam de Houghton. Also rendering to the lord for the sair holdings at Aichaelmas one bawk or soar-hawk, or six shillings and eightpence.

The same hold a carve of land in Grywesrghe, in thanage, paying yearly at the fonr terms as ahove, three shillings, relief, etc., as above. ${ }^{1}$

21 Richard II.

ADAiI de CatTerall.

15 August, 1397.

Inruisition taken on Tuesday, in the Feast of the Assumption of the Blessed Virgin Mary in 21 year of Richard the Second, on onth of Thomas de Hesketh, John de Townlay, Thomas de Barton, Nicholas de Singleton, Joln de Radeliffe de Urdesall, William de Singleton, Richard de Singleton, John de Haydok, Robert de Gosuar, John Lawrence de Pulton, \&c. Who say upon their oath that when Adam de Catterall, who held in chief from the Lord Duke, died, he was seized in his lordship as in fee of the manor of Little Mitton, with appurtenances in Blakebnrnshire, by service of paying nine pence for defence of the camp. Likewise they say that the same Adam lield the third part of the manor of Catterall from Thomas de Rigmaden, by military service, paying three pence yearly for defence of the camp, which Thomas was indeed under age and in charge of the Duke. Likewise they say that the same Adain held a messuage of 20 acres of land and meadow and 80 acres of pasture in Gosenargh of the Prior of St. John of Jerusalem. And they say that Issahella, mother of the said Alam, holds in dowry a third part of the manor of Gosenargh of the Dnke, in socage, which tlirird part onght indeed to revert after the death of the said Issabella to Richard, son and heir of the said Adam. Likewise they say that the same Adam, a long time before his death, gave a fourth part of the manor of Wrightington to one Laurence de Mirescogh, chaplain, which third part is beld of John le Ware, Knight, by military service. And 74.

${ }^{1}$ Survey, 1320-46. Cheth. Soc. vol. 
they say that the same Adam held a messuage in Inskip, which is held of the Duke in socage, value 11s. Likewise they say that Adam died 28 February, in the 20th year Richard the Second. And that Richard, son and heir of the same Adam, is of the age of 15 years.

The Cliftons were also large landowners in the district.

From a comparison of the corn and wool taxes levied upon Goosnargh and Whittingham with those levied in other parishes, Goosnargh in the reigu of Edward III. was a very prosperous district.

And it is as an agricultural district that Goosnargh is best known. Goosnargh cheese and Goosnargh butter are known all over England as being of the best quality. Prizes for cheese especially are being constantly gained by the farmers of this thriving agricultural district.

The leading landowners are Thomas Oliversou, Esq., Loudon; the late Townley Rigby Knowles, Fishwick, Lancashire; and the representatives of the late George Hargreaves, Leyland. The rents are high, and, while complaining of this, the farmers are, as a class, very rell-to-do.

Agricultural Statistics.

Number of Statute Acres under-*

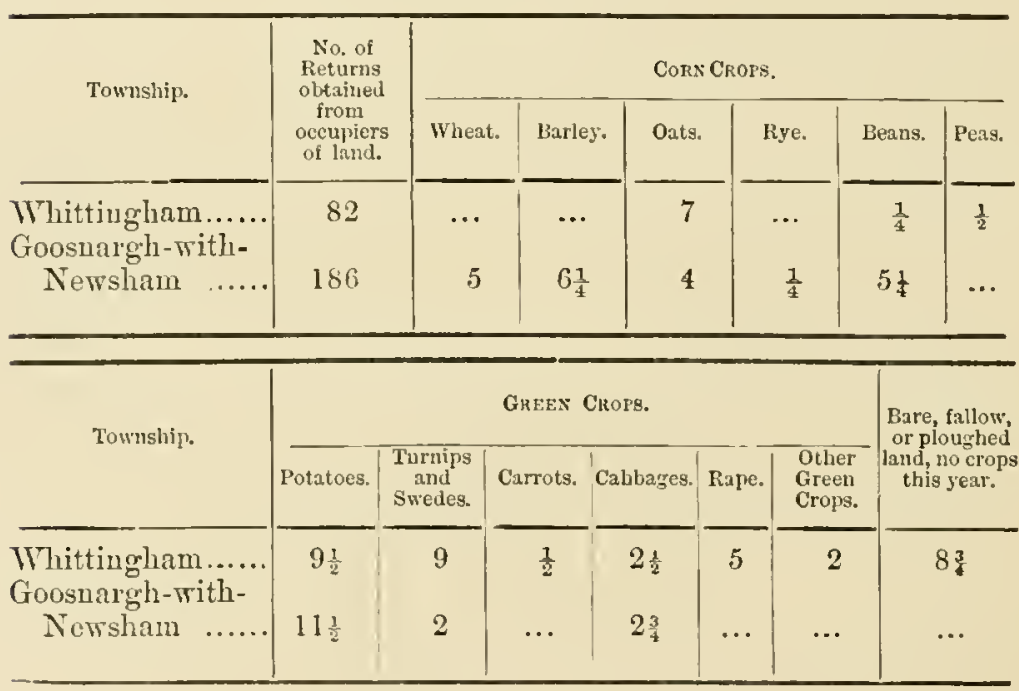




\begin{tabular}{|c|c|c|c|c|c|c|}
\hline \multirow{2}{*}{ Township. } & \multicolumn{2}{|c|}{$\begin{array}{l}\text { Grass Land cut for lay } \\
\text { this year. }\end{array}$} & \multirow{2}{*}{$\begin{array}{c}\text { Grass land } \\
\text { not to be cut } \\
\text { for hay } \\
\text { this year. } \\
\begin{array}{c}\text { Permanent } \\
\text { Grass or Meadow }\end{array}\end{array}$} & \multirow{2}{*}{ Orclinrds. } & \multirow{2}{*}{$\begin{array}{c}\text { No. of } \\
\text { Built Silos. }\end{array}$} & \multirow{2}{*}{$\begin{array}{l}\text { No. of } \\
\text { Stacked } \\
\text { Silos. }\end{array}$} \\
\hline & $\begin{array}{l}\text { Clover, } \\
\text { \&c. }\end{array}$ & $\begin{array}{l}\text { Permanent } \\
\text { Grias or } \\
\text { Bleadow. }\end{array}$ & & & & \\
\hline Whittingham ... & 29 & $931 \frac{1}{4}$ & $1960 \frac{1}{4}$ & $9 \frac{1}{2}$ & 5 & 6 \\
\hline $\begin{array}{c}\text { Goosnargh.with- } \\
\text { Newsham ... }\end{array}$ & 23 & $2195 \frac{1}{2}$ & $5914 \frac{1}{4}$ & 18 & 2 & 8 \\
\hline
\end{tabular}

*Quantities less thau $\frac{1}{4}$-acre not included.

IIYE STOCK oN 4TH JUAE, 1886.

\begin{tabular}{|c|c|c|c|c|c|c|c|c|}
\hline \multirow[b]{2}{*}{ Township. } & \multirow{2}{*}{$\begin{array}{c}\text { No. of } \\
\text { Returns } \\
\text { obtained } \\
\text { from } \\
\text { occupiers } \\
\text { of land. }\end{array}$} & \multicolumn{4}{|c|}{ Number of Horses. } & \multirow{2}{*}{$\begin{array}{l}\text { Number of } \\
\text { Cows and } \\
\text { Heifers of all } \\
\text { Ages, in Milk } \\
\text { or in Calf. }\end{array}$} & \multicolumn{2}{|c|}{$\begin{array}{c}\text { NUMBEER OF CATTLE } \\
\text { OTHER THAN THOSE IN } \\
\text { MILK OR CALF. } \\
\end{array}$} \\
\hline & & $\begin{array}{l}\text { Agricul. } \\
\text { tural } \\
\text { Solely. }\end{array}$ & $\begin{array}{c}\text { Un- } \\
\text { broken } \\
\text { IIorses } \\
\text { of any age }\end{array}$ & $\begin{array}{r}\text { M } \\
\text { h } \\
\text { sole } \\
\text { Bre }\end{array}$ & \begin{tabular}{l|l} 
lares & $\mathrm{H}$ \\
kept & $\mathrm{At}$ \\
ely for & $\mathrm{A}$ \\
eeding &
\end{tabular} & & $\begin{array}{l}2 \text { years } \\
\text { old and } \\
\text { above. }\end{array}$ & $\begin{array}{l}\text { Under } \\
2 \text { years. }\end{array}$ \\
\hline \multirow{2}{*}{$\begin{array}{l}\text { Whittingham... } \\
\text { Goosnargh-with. } \\
\text { Nowsham ... }\end{array}$} & \multirow{2}{*}{$\begin{array}{r}82 \\
186\end{array}$} & 52 & 44 & \multicolumn{2}{|r|}{2} & 645 & 197 & 554 \\
\hline & & $1: 9$ & 89 & \multicolumn{2}{|r|}{2} & 1502 & 277 & 1478 \\
\hline \multirow{2}{*}{ Townslip. } & \multirow{2}{*}{$\begin{array}{l}\text { Number of } \\
\text { sheep of } \\
\text { all kinds } \\
1 \text { year old } \\
\text { and above. }\end{array}$} & \multirow{2}{*}{$\begin{array}{c}\text { Number } \\
\text { of Lanbs } \\
\text { under } \\
\text { one } \\
\text { year. }\end{array}$} & \multirow{2}{*}{\multicolumn{2}{|c|}{$\begin{array}{l}\text { Number } \\
\text { of Pirs } \\
\text { of all } \\
\text { kinds } \\
\text { and ares. }\end{array}$}} & \multicolumn{4}{|c|}{ Number of Poultr. } \\
\hline & & & & & Turkeys. & Geese, & Ducks. & Fowls. \\
\hline Whittingham... & 451 & 38 & 361 & & 1 & 61 & 225 & 1735 \\
\hline $\begin{array}{l}\text { Goosnargh-with- } \\
\text { Newsham ... }\end{array}$ & 1659 & 148 & 219 & & 20 & 243 & 423 & 5063 \\
\hline
\end{tabular}

* Probably considerably under the numbers.

Goosnargh is also noted for its cakes. The number of these cakes sold last year realised the large sum of $£ 600$, a fair proof of their popularity. 
Goosnargh has, too, a rather unenviable notoriety for roads. A popular local saying is, "that there are as many roads in Goosnargh as would reach to London." The extent of them, as given by the Ordnance Survey, is 35 miles. The number of cross roads makes travelling rather difficult for strangers.

Goosuargh is not a "village," nor a "hamlet:" it is an "agricultural-district." True a few houses scattered about the neighbourhood of the Church are called "Goosnargh Village"-a title as misleading as it is incorrect. It has been most aptly termed "a nook" by Mr. E. Kirk, who thus describes his native place. "The land rises from the flat Fylde like a majestic swell of the mighty ocean rushing between two high lills, chopped and furrowed on its surface into a hundred hillocks, mounds and breezy brows, striated with babbling brooks and purling rills. The laud rises from about two hundred to four hundred feet above the sea, and from its crest water performs what is thought to be a wouder, by flowing eastwards for several miles. Althongh the western point is sixteen to eighteen miles from the sea, it is not an uncommon thing for salt water to he found on the feuces, aud yews are occasionally turned brown on the west side by the briue of the Irish Sea."

\section{Tile Parisil Church.}

The date of the foundation of Goosnargh Church, dedicated to St. Mary, is merely a matter of conjecture. Baines says it is of great antiquity. Dr. Whitaker cousiders the present edifice a restoration of the building existing in the reign of Heury VIII. Fishwick says it is certain there was a chapel here in 1330. A chantry was in existence in 1553. The registers date from 1639 , and the church was restored in 1778 , and again in 1868-9. The style of architecture is mixed. A brass tablet is in the church to the momory of William Bushell, Esq. Two other tablets are orected to the memories of James Sidgreaves, Esq., and John Burch Parker, Esq. On the floor of the tower is an inscription to the effect that Villiam Bushell, Rector of Heysham, was minister here for the time being, dated 1715. There is a peel of six bells in the tower. The oldest tombstono in the churchyard bears the date of 1668. $\Lambda$ sundial in the churchyard bears the 
date 1748. An upright cross pedestal also stands in the churchyard. The patronage of the church is vested in the Dean and Chapter of Christ Church, Oxford. The living is returned as follums:-£260, with a house. Sittings, 500, 499 of which are freo.

The school is a very substantial building, under the management of trustees. There is an average attendance of 95 children.

\section{Vicars of Goosmargit.}

Rev. William Corbays (1330) is the earliest known Vicar. The last threo are-Rev. R. Studholme (1822-67), Rev. W. Shilleto, B.A. (1867-83), and the present Vicar, the Rev. C. O. Gordon, MI.A.

RET. WILLIANI SHILLETO.

Mr. Shilleto was a serious, rather self-opinionated geutleman, a plain preacher, a man of good oducation, with High Church notions. Anxious though he was to promote the best interests of the church, he did not get on very comfortably with his people. He died in $\mathbf{1 8 8 3 .}$

REY. CIIARLES OSBORNE GORDON.

The Rev. Charles Osborn 3 Gordon is short and portly, clean-shaven, and with an imperious air on his somewhat severely classical fcatures. The Vicar of Goosnargh in his personal appearance reminds one strikingly of the great Napoleon. And, strange to say, judgingr from the way in which Mr. Gordon has tried to govern the parish, his mind is, apparently, moulded in a somewhat similar fashion to that of the great dictator-with, howover, this important difference-Buonaparte was above all things a master in the science of tactics, while the reverend gentleman is not. We are sorry to say that Mr. Gordon has quarrelled with many of his congregation - with the bellringers, the organist, and the choir. Hard and bitter words have been used by both Vicar and people; and what was a slow and somewhat dull, but at anyrate a peaceful, congregation, has in a few short years become disunited and discontented. But not content with upsetting his own flock, Mr. Gordon is unpopular among the Dissenting portion of his parish. He is by no means a good preacher, is a strong Tory, and dislikes ontside interference in his parish by "wandering" politicians. 


\section{Roman Catholic Churches.}

The Hill Roman Catholic Chapel was erected about 1750, taking the place of an older one which formerly stood near Whitehill; there is belonging to it a house for the priest and a permanent endowment. The registers date from about 1770 . The Chapel was rebuilt in 1802, and enlarged in 1834. Inscribed in front is, "Glory to God on high, MDCCCXXXV." Near the entrance to the Chapel is an upright cross. The Chapel is a plain-looking building, and will seat about 300 persons. The list of priests is as follows:-

\begin{tabular}{ll}
- & Rev. Mr. Tootle. \\
\hline 1777 & Rev. Mr. Fleet. \\
1802 & Rev. Joseph B. Martin, O.S.F. \\
1834 & Rev. E. Dinmore, O.S.B. \\
1879 & Rev. Matthew Brierley, O.S.B.
\end{tabular}

There is a School in connection with the Chapel.

The Rev. M. Brierley has sent me the following figures which are very interesting and instructive :

\begin{tabular}{|c|c|c|c|}
\hline \multirow[b]{2}{*}{$1777-1802$} & \multicolumn{2}{|c|}{ Baptisms: } & \multirow[b]{2}{*}{$1879-88$} \\
\hline & $1802-34$ & $1834-79$ & \\
\hline 480 & 912 & 503 & 55 \\
\hline \multicolumn{4}{|c|}{ Average per year: } \\
\hline 19 & 28 & 11 & 6 \\
\hline \multicolumn{4}{|c|}{ Probable average number of Catholics: } \\
\hline 570 & 840 & 330 & 180 \\
\hline
\end{tabular}

The above figures are truly remarkable, showing a decrease in the Catholic population of Goosnargh of no less than 70 per cent. in 100 years. I am unable to state the causes of this astonishing decrease: I can only record the fact.

REV. FR. MATTHEW BRERLEY, O.S.B.

The Rev. M. Brierley has been at the Hill Mission for 9 years. He lives a retired life, working quietly among his flock. He is the chaplain at Whittingham Asylum, whore he holds weekly services. 


\section{Dean House Chapel.}

An old Roman Catholic Chapel formerly stood near Dean House, Whittingham. It was pulled down in 1840. Over one of the doors was the following inscription :-

\section{R.I.E.L.}

It was probably a private Chapel, and the letters R.I.E.L. refer to the owners of the place. There was also a wooden cross, now at the Hill Chapel.

\section{Newhouse Chapel.}

There is also a Roman Catholic Chapel at Newsham, commonly called Nerwouse Chapel. Over the doorway is inscribed :-

\section{IIDCCCVI.}

\section{In hoc Signo Tinces.}

List of Priests.

1740 Rev. John Carter.

1762 Rev. James Carter.

1812 Rev. Henry Mandesley.

1826 Rev. J. B. Marsh.

1854 Rev. Peter Holmes.

1855 Rev. Canon Richard Gillow.

1867 Rer. W. H. Bradshaw.

1868 Rev. Pierce Powel.

1869 Rev. Anstin Powel.

1872 Rev. John Bilsborrow.

- Rev. Thomas Carroll.

The Church will hold about 300 people.

A School was crected in 1863; the average atteudance being about 35 .

An interesting history attaches to Newhouse, which has been well told by Gillow in his recently published "Haydock Papers":

Facing the entrance to the pretty little Chapel at Nowhouse, Newsham, were two table-monuments, which have recently been desecrated by having their supports removed, in order to increase the width of the pathway, and to allow people to walk over and deface the inseriptions. The one covered the remains of the Haydocks, of Leach Hall, and the other the Haydocks, of the Tagg. ${ }^{1}$

" "It is to be hoped," adds MIr. J. Gillow, "that these two tombstones will be restored to their original coll. dition, and allowed to remain a
memorial of the breaking downof intolerance." (See page 239.) 
About 1740 the Newhouse Chapel was built; it was small and irregular in shape, and ledicated to St. Lawrence. The Rev, John Carter, from the English College at Lisbon, was the first priest regularly stationed here. When Prince Charles Edward passed by in 1745, on his march to Preston, Mr. Carter obtained an assurance from him, that his troops should not molest either his person or the mission property. In 1763, during the anti-Jacobite and no-Popery fermentation at Preston, Newhouse Chapel narrowly escaped destruction. An infatuated mob, after destroying St. Mary's Chapel, in Friargate, Preston, and burning that at Cottam, moved in the direction of Newhouse for the purpose of demolishing the Chapel there. But a neighbouring Protestant, named Hankinson, a descendant of the family of the man who betrayed George Haydock, the Martyr, met the mol near Hollowforth Mill, and persualed them not to touch the Chapel. $\mathrm{He}$ entreated them not to molest Mr. Carter, whom he highly praised. He then provided them with food and drink, which appeased them, and thus they marehed back to Preston. Mr. Carter died Oct. 11, 17S9, hut long before his death, about 1762, his nephew, James Carter, eame to assist him in the Mission. Mr. Carter, in accordance with the general custom of priests, assnmed his mother's maiden name (Mawilesley), by which he was always known. He remained at Newhouse for 52 years, and there died Feb. 4, 1S14, aged 7S, a marble tablet within the Chapel recording his memory. Towards the close of his life, he was assisted by his nephew, the Rev. Henry Carter, younger son of Robert Carter, and his wife, Jane Cope, or Cooper. He came to Newhouse in 1805; and through his exertions the present Chapel was erected in 1S06, near the old site. With a view to preventing any ill-feeling or difficulty with the Protestants, whose Chapel at Darton, about a mile distant, was dedicated to St. Lawrence, the old patron of Newhouse was abindoned, and the new edifice dedicated to our Lady. In 1526, Mr. Carter died at Preston; and was succeeded by the Rev. J. B. Marsh. who died in 1557, and was buried at the north-east corner of the Chapel. It was he who erected the Presbytery, adjoining the Chapel, soon after his appointment to the Mission. He was succeeded in 1554, by the Hev. Peter Holmes; Mr. Holmes only stayed a year. He was followed iu 1855 by the V'ery Rev. Richard Canon Gillow, who has been Vice-Rector of the English College at Rome, and twelve years Professor of Theology at Ushaw College. He died at Newhouse, Nov. 3rd, 1S67, and was burierl under a handsome stone, adjoining that to the memory of Mr. Marsh, crected by his friend, Thomas Fitzherbert Brockholes, of Claughton, Esq. Soon aftcr he came to the Mission, Canon Gillow erected the Schools, a short distance from the Chapel. He was succeedcd by the Rer. W. H. Bradshaw; then came the lev. Pierce Power, who cut down the fine old slurubs surrounding the house, and destroyed its heauty. In May, 1S69, followed the Rev. Austin Powell, who redecorated the Chapel, and did much to improve the place; then in September, 1872, came the Rev. John Bilsborrow, a descendant of the donors of the Bilsborrow charity, of which the priest at Newsham should be a recipient; and lastly came the present incumbent, the Rev. Thomas Carroll. 
When the Rev. Henry Carter had erected the new Chapel in 1806, he opened a I urial ground to the great ire of the parson of Goosnargh, the Rev. Joshua Southward, who denauded the interment fees, and began to assume a threatening attitude.

$$
\begin{aligned}
& \text { "Holl ! I forgot-one sail, a parson'sdnes } \\
& \text { Was the same thing with rhyming balge of Jews." }
\end{aligned}
$$

-John Byrom.

At length on September 10, I810, he wrote the following letter to Mr. Carter:-

"Reverend Sir, -I hear not from you, nor what you mean to do, concerning sepultures in a piece of ground near to your Chapel. You must know that you have no right to ieposit bodies there, under a heavy penalty, and that at present, as minister here, I an cheated of the usual fees. Suppose your Chapel was consecrated accorling to the rites and ceremonies of the Church of England, corp's (sic.) conld not then be interred in the conseerated ground adjoining, to the deprivation of our fees here. Yon probably may not be aware, by your improper conilnct, what mischief you are doing to your body and the Catholic cause, both here and in Ireland. The State has already been kind and indulgent to you, and you may still go on to look for more privileges, but you may depend npon this, that the higher powers will not long remain ulacguainted with the mnlue advantage you at present take of the Established Church, and which must be a great check for anything more to be done for you. At present $I$ have a correspondence with the Bishop of Chester upon this business, and unless I soon, to my satisfaction, hear from you, I shall write to your Romish Bishop, Dr. Gibson, upon the subject-nor shall $I$ cease from cxerting my right in our Ecclesiastical Court.

All I want is primarily the fees paid here, and then it is nothing to me how much you can get afterwards. - I am, with all dne reverence and respect, cte.; SourtrWARD, Minister of Goosuargh."

It was the burial of Mrs. Haydock, of Leach Hall, and the Rev. James Haydock, of Lea, which cxcited the avarice of this eharacteristic follower of the loaves and fishes.

\section{REV. CANON RICHARD GILLOW.}

A brief account must be given-exigences of spaco reluctantly compelling the author to make the notice as concise as possible-of the Rev. Richard Gillow, who for twelve years was the honoured and loved priest of Newsham. He was one of those men, "whose mission was toilsome aud onerous, who had to sow in tears, but had at length the satisfaction of reaping in joy. The lopped tree grew again beneath their fostering care; it threw out new roots and new branches, and spread its umbrageous arms over the length and breadth of the land.'

The subject of this sketeh was born at Newton, in the Fylde, on the 18th July, 1794. Edneated at Ushaw College, he soon became noted 
for the zeal, ardour, and assiduity with which he devoted himself to learning, and was equally celebrated for his piety and religious fervour. He was appointed Vice-Rector of the English College at Rome about 1821-2, a position he retained until 1825. He was then for twelve years Rrofessor of Poetry, Philosophy, and Theology at his alma mater, Ushaw. After being at Puddington, near Chester, Euxton, and Chorley, for some years, lie came to the place where he passerl the closing years of his life. His promise of zeal he displayed when at school was fully realised in Mr. Gillow during life. It is said that he celebrated mass, etc., when scarcely able to stand through weakness. Peacefully and quietly he passed away on Sunday, Nov. 3rd, 1855, leaving his people to mourn for one who had been their friend, their counsellor, and guide. He was followed to the grave by a distinguished company of Catholic clergy. In private life he was a man of few wants; frugal and self-denying, he was kind and indulgent to others, and had a heart and hand "open as day to melting charity." He lies interred in the cemetery at Newsham, his grave being next to that of his predecessor, the Rer. J. B. Marsh.

Independent Church.

On the south side of Inglewhite there is the chapel of the Independents. It is a small, simple-looking buiiding, and was built in 1826, its founder being Mr. John Bird, of Trotter Hill, Goosnargh. The building has a clean, cheerful interior, is pretty well attended, has a good choir, and has for its minister the Rev. Joln Hargreaves.

List of Ministers.

1888 Rev. Jolnn Anyon.

1832 Rer. W. Hackett.

1839 Rer. Geo. Bury.

1845 Rev. R. Barker.

1853-57 Rer. P. Haworth.

${ }^{1} 1869$ Rev. Jolin Spencer.

1880 Rev. John Hargreaves.

The chapel has lately been renorated at a cost of over $£ 200$. The present minister, the Rev John Hargreaves is a very earnest worker, a fair preacher, and has been successful in his ministrations.

${ }^{1}$ There aplears to have been sun interregnum for 12 years. 
Wesleyan Churct.

The Wesleyan Chapel isclose to Goosnargh "village." Itwas erected by subscription in 1832, and was enlarged in 1869 . It is a very plain building indeed-so plain one would hardly take it for a chajel at all. It will seat 150 people. Minister's are supplied every Sunday by the Garstang circuit.

The "sworn men" or "twenty-four" of Goosnargh still meet every year. Their duties are, however, considerably shorn of their former importance. They are supposed to have been in existence long before 1634 , the year in which the first complete list is given. Their records are curious and amusing.

The Goosnargh Hunt is also kept up.

Local Celebrities.

REV, FR. WILLIAM MARSDEN.

"Probably it was," says Monsignor. Gradwell, "early in the reign of Elizabeth that William Marsden was born, at a small farm in Goosuargh, called 'The Mountain.'" Probably, too, he was a playfellow of the Rev. George Beesley, who lived only three miles away, at "The Hill."

"We have, unfortuuately," continues Monsignor Gradwell, "no particulars of the way in which they procured the necessary preliminary education. All we know is that William Marsden arrived at Rheims, July 10th, 1580. Robert Anderton, of the Andertons of Lostock, was a companion of Marsden. On March 25th, 1581, they received Minor Orders in the Church of Our Lady at Rheims, at the hands of the Bishop of Chalons. On February 4th, 1586, the two youmg men set out together to confront the labours and risks of a priest's life in their own country. A storm axising in the Channel, they were cast on the shores of the Isle of Wight. They had scarcely set foot on shore before they fell into the hunters' nets. Soon after they were brought to the bar, where the judge examined them, and finally coudemned them to death, and they suffered the usual butchery 'with constancy and intrepidity, and so obtained a noble martyrdom.' They were executed iu the Isle of Wight on the 25th April."1

${ }^{1}$ Liverpool Catholic Diocssan Almanack-1888. 
Such is the story, told in a "few and simple words" of "the saintly life and glorious death of the Goosnargh Martyrs"-George Beesley and Wilkiam Marsden.

REY. FR. AEORGE BEESLEY.

"Rev. Fr. George Beesley was born at a placecalled "The Mountain," in Goosenor [Goosnargh] parish, in Lancashire, and was an alummus and priest of Douay College, during his residence at Rhomes [Rheims]; he was ordained priest in $1587,{ }^{1}$ and sent upon the English Mission in 1588. He was a man of singular courage, young, strong, and robust, before he fell into the hands of the persecutors; but whilst he was in their hands, he was so frequently and cruelly tortured by the unhappy Topeliff, in order to oblige him to confess what Catholics he had conversed with, and by whom he had been harboured or relieved, that he was reduced to a mere skeleton, insomuch that they who were before acquainted with him could scarce know him to be the same man when they" saw him drawn to execution. Yet all these torments he endured with invincible courage and patience, and would not be induced to name anyone, or bring anyone into danger on his account. He was condemned merely for his priestly character and remaining in England contrary to the statute of Eliz. 37, and was hanged, bowelled, and quartered in Fleet-street, July 2, 1591."2 -Challoner's Missionary I'riest.

REV. FI. EDWARD CLARKSON.

" 1815 , July 16. At 8 o'clock in $y^{\mathrm{e}}$ morning, departed this life of ye Rev. Edward Clarkson, and was buried iu Holme Churchyard on $y^{e}$ left side of his jredecessor, Rev. 'T. Marsh. Weldon's 'Chronology' identifies him as 'Dom Albans, Edwerd Clarlison, of Goosnargh, Lancashire,' and as professed Nov. 11th, 1787."

RET. FR. JOHN CLARKSON.

"Rev. John Clarkson, boru at Erinsargh, Lancashire, escaped from Douay, France, Nor. 24, 1793, ordained Priest at Old Hall Green. Missioner at Ingatestone, Essex. Died Feb. 12, 1823."

${ }^{1} 1586(?) .1586(?)$

'See Mgr. Gradwell's account. 
Rev. John Clarkson was one of a small band of young men, selected for their prudence and daring, to convey the valuables belonging to the Donay College from the Revolutionary despoilers. He ran a great risk at such a time and in such an undertaling, but lis courage never failed him, and he executed his task.

FATHER REV, ROGER ARROWSMITI.

The Rev. R. Arrowsmith was born at Inglewhite in 1823. He was the priest of many missions, including Liverpool, Lytham, and Poulton. $\mathrm{He}$ resigned in 1885 through ill-health; diec Fobruary 14th, 1886, and is buried at the Willows, Kirkham.

\section{HENRY KIRK.}

Mr. Henry Kirk was a brother of Edward Kirk, of Goosnargh. $\mathrm{H}_{\theta}$ was the author of several poems, some of which are published in "Ballads and Songs of Lancashire." The following verse, from "Bertha," will give some idea of Mr. Kirk's poetical powers :-

Low, by Ribble's scaury sicle, Swept the soft autumual breeze ;

Faint its whisp'ring murmurs died, High in Tonbrook's crowded trees.

Sad, at intervals, the grove Shook beneath a fitful blast:

Like a heart that vainly strove Back to crush some sorrow past !

Henry Kirk was born at Goosnargh, on the 20 th September, 1834. $\mathrm{He}$ is living, I believe, in or near London.

He printed, for private circulation, in 1871, a poem ontitled "Kilcolman Castle: a Pilgrimage to the Home of Spenser" (12mo., pp. 9).

EDWARD KIRK.

The late Mr. Edward Kirk, who was so widely known in the literary and archeological circles of South Lancashire, was a native of Goosnargh. Echucated at the village school, he soon acquired a taste for literature, which stood lim in good stead in after-life. After a time he became the editor of the Eectes Adrertiser, and also an active nember of the Manchester Literary Club. He was one of the founders of the Lancashire and Cheshire Antiquarian Society, at whose meetings he read many highly-appreciated papers on Roman Roads. For some 
years he wrote under the nom de plume of "Cuthbert Oxendale." Mr. Kirk was true to the early traditions and training of his home life. He always took a keen interest in the district in which he was born, and often with pleasure did he visit the haunts of his youthful days. He died March 24th, 1885, deeply regretted by a wide circle of friends, at the early age of 53 , leaving a widow and seven children to mourn his loss. He was a man of fine presence, and of stalwart frame; was genial and kindly, and deserves to be remembered by the people of the district in which he was born, and which he loved so well.

$$
\text { RICHARD COOKSON. }
$$

The late Mr. Cookson, the author of the Goosnargh Rambler, 999 Thoughts, and Goosnargh, Past and Present, was schoolmaster of his native place for forty years. During his life-time, Mr. Cookson was much respected; and his books had a fair circulation. But we fear his reputation as a writer has suffered much since the publication of his so-called history; for the style is paltry, the information trite, and the observations generally puerile. He will be most remembered for his eccentric will. By this document, all the good Cookson did-all the lessons of prudence, sobriety, and thrift which he taught in the school, and in his books, stand a fair chance of being wrecked. The will is now in the Court of Chancery, and its provisions will, no doubt, be declared void. Mr. Cookson died a few months ago, at a ripe old age.

Mr. Peter Whittle, the bookseller and historian of Preston, is another Goosnargh celebrity.

Near Goosnargh, but in the township of Whittingham, is the large County Lunatic Asylum, pleasantly situated on some gently-sloping ground. Whittingham Asylum (formerly called "Gotfield," and long the residence of the Waring family,) was built in 1869 by Cooper and Tullis, contractors, Preston; and was further enlarged by them in 1879. The number of patients at present in the asylum is 1,250. To attend to these sufferers, there is a governor (Dr. Wallis), assisted by a staff of medical men, and several hundred male and female attendants. Everything that can help to alleviate the sufferings of these poor inmates is to be found at Whittingham: nicely laid-out grounds, a 
cricket ground, gymnasium, and an efficient band. Balls, concerts, and theatrical performances are given by amateurs from the surrounding districts, and are much enjoyed by the poor lunatics. There is a large farm in connection with the asylum, and vegetables and fruit are grown in great quantities. ${ }^{1}$ A tramway has just been completed between the asylum and Grimsargh station, on the Preston and Longridge Railway line. We venture to hope that this tramway will, in a short time, be open to the people of Whittingham and Goosnargh, as in such a case the district would be largely developed.

Goosnargh Hospital, founded in 1735 by "Dr." William Bushell, well described by Whittaker as "the pleasantest and most accommodating eleemosynary foundation," provides a home for decayed gentlemen or gentlewomen, from certain specified places, who are not paupers or Catholics. The present number of inmates is 30 . The Trustees are :-Dr. Hammond, J.P., Messis. W. P. Park, J.P., R. Pedder, J.P., and John Smith.

There are other numerous charities for the poor.

The old halls in Goosnargh are:-Middleton Hall, long the seat of the Rigbys; Bulsnape Hall, the residence of the Catteralls and the Fishwicks; Ashes, over the front door of which is a singular looking figure; Inglewhite Lodge, the ancestral home of the Sidgreaves family; Whinney Clough; Whittingham Hall ; Chingle (Gingle) Hall, once the residence of the old and powerful family of the Singletons; and Dun Cow Rib, built in 1616 by Adam Hoghton. To this latter house a similar story to the one related in Chapter IX is attached. A full account of this house is given in Gillow's Haydock Paypers.

Near Inglewhite is a curious spring called St. Anne's Well. At the bottom of it there is a stone bearing the inscription, Fons Sancta Anna. Dr. Leigh, who visited Lancashire in 1699, gives a good description of the spring. He compares it to the famous Harrogate waters.

In the centre of Inglewhite Green (one of the most perfect examples of a village green in Lancashire) are the remains of a market cross raised above the ground by five steps. It is upwards of ten feet high,

${ }^{2}$ In the course of a visit paid to the asylum a few weeks ago, I was struck with the general air of comfort-or rather luxuriousness-which prevailed. 
and quite perfect, except that the arms of the cross have long ago disappeared. Upon the shaft is inscribed:-" $\mathrm{H} \times \mathrm{C} \times \mathrm{J} \times \mathrm{W} \times 1675$." The latter two initials no doubt refer to Mr. Justice Warren, who was at that time Lord of the Manor, but the cross itself is at least (says Fishwick) a century and a half older than the inscription.

As recently as 1819 the chief fair of the year was held on Sunday. Silk and cotton manufacture were carried on here by water and hand power, but there are no manufactures carried on now. ${ }^{1}$

The area of Goosnargh is 8,672 statute acres, that of Newsham 370 acres, and that of Whittingham 3,190 acres, nearly all of which are under cultivation.

The population has for some years been decreasing, as the census returns show :-

Goosnargh-with-Newsham-1801-1558; 1811-1562; 1821-1852 ; $1831-1844 ; 1841-1621 ; 1851-1453 ; 1861-1307 ; 1871-1258$; $1881-1197$.

Whittingham-1801-529; 1811-529; 1821-661; 1831-710 ; $1841-691 ; 1851-677 ; 1861-583 ; 1871-664 ; 1881-2158 .^{2}$

At this period 40 or 50 years agodrinking, dancing, and gambling were carried on to an enormous extent. MIy mother has often told mo how one man ventured his farm-Loudscales-at a game of "vut" on an ace, a two, and a three. He lost, and exclaimedAce, dence, and tray, Loudscales, go thi way.

${ }^{2}$ There wonld be at least 1,600 pecple at the Whittingham Asylum in 1581. 



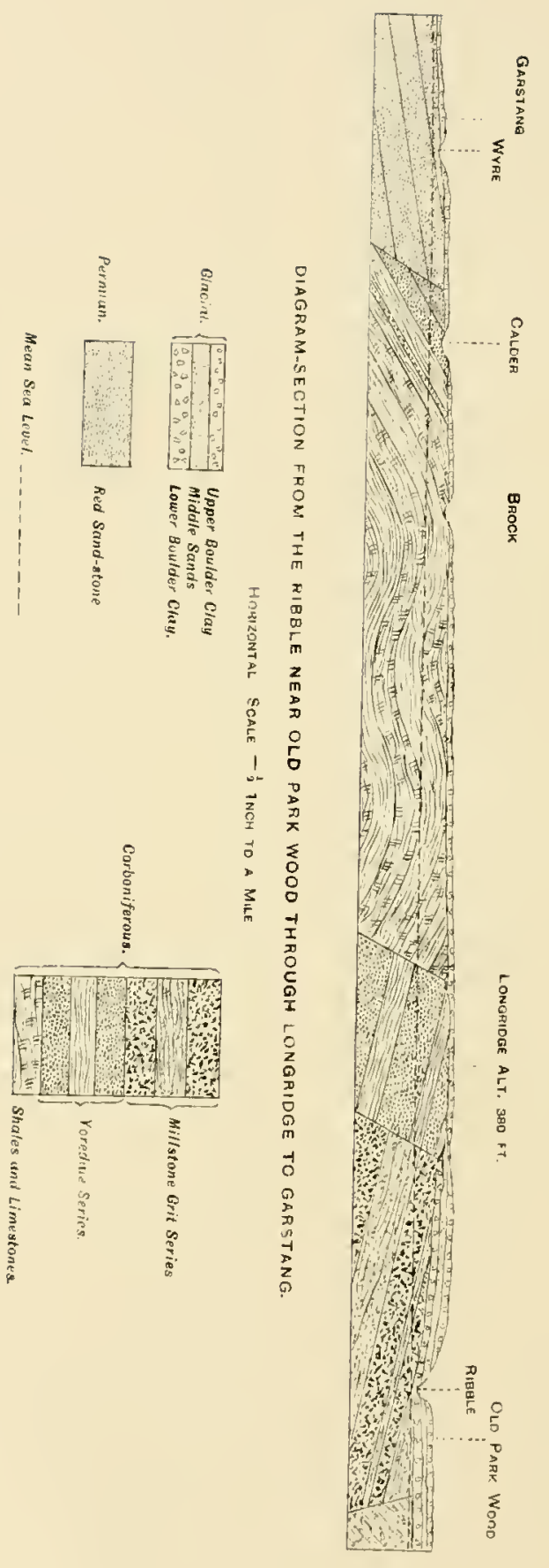




\section{CHAPTER XII.-PHYSICAL HISTORY, GEOLOGY, AND} BOTANY OF THE DISTRICT.

By F. C. King.

Geology and Physical History of the District.

Generally, the geology of a district is more or less importaut and interesting in direct proportion to the commercial and indnstrial significance of its mineral deposits. In the absence of such deposits, howover, it does not follow that the study of the geology of any district is void of either interest or importance.

In these days of scientific agriculture, a knowledge of the nature of the soil resulting from the denudation and dogradation of the surrounding rocks is essential to the agricnlturist if he would snccessfully compete with his fraternity. With a knowledge of the compositions and capabilities for retention of moisture of the surface-soil, sub-soil, and underlying rocks, comes a knowledge of the requirements in the matters of draining, deptli of cultivation, and application of suitable manures necessary to render the land perfectly fertile without waste of material or labour.

It is also a matter of rery great moment to the residents in any district that they should have some knowledge of the water-bearing properties of the rocks around them, the character of the water yielded, and the possibilities and probabilities of a continuous supply during a long-continued drought.

Again, a knowledge of "the rocks" and of their order of superpositiou is absolutely indispensable to success in a search for those hidden mineral treasures which have rendered such valuable aid in the building of the British Empire.

Apart from considerations of practical utility, it must be matter of absorbing interest to enquire respecting the past history of our mother earth. To learn why certain rocks appear at the surface in one place, while different rocks show themselves in another; why valuable mineral deposits are found in one district, and are altogether abseut in an adjoining one; and why some parts of our country are level, while others exhibit an undulating or even mountainous aspect. These and 
many ather kindred matters of equal interest are made clear to the student of gcology. His tutors are tho rocks themselves.

Within the limits of a chapter it will be impossible to give more than a bare outline of the geology of the district and of the physical changes that have occurred since the oldest rock was laid down. This, however, will be given in as interesting a manner as the space will admit, in the hope that it will stimulate to further investigation.

On a geological map of England, Longridge is seen to be situate a short distance from the edge of the Lancashire coal-field and on the slope at the extremity of a spur of the Pennine Range.

The underlying rocks are members of the Yoredale series, and these, together with all the solid rocks in the immediate vicinity, are members of the carboniferous system. They do not often appear at the surface, but are mostly obscured from view by a covering, sometimes several feet thick, of boulder-clay, of drift-sands and gravels, or of surface soil, or of two or more of these deposited one above the other. (See plate 1).

That most important member of the carboniferous system, the Coal Measures, the presence of which would constitute Longridge a place of great commercial importance, is wanting. But so nearly do some of the rocks in the neighbourhood resemble certain beds associated with the coal-measures that in days gone by they were frequently mistaken for them, and the remains of shafts which have been sunk in search of coal may yet be seen in the basins of the Ribble and the Hodder. ${ }^{1}$

As all the members of the carboniferous system do not occur in this district, it will be well to give here a table of the complete system with a table of the carboniferous rocks of the district for comparison.

The following are the principal divisions that have been made in carboniferous rocks:-

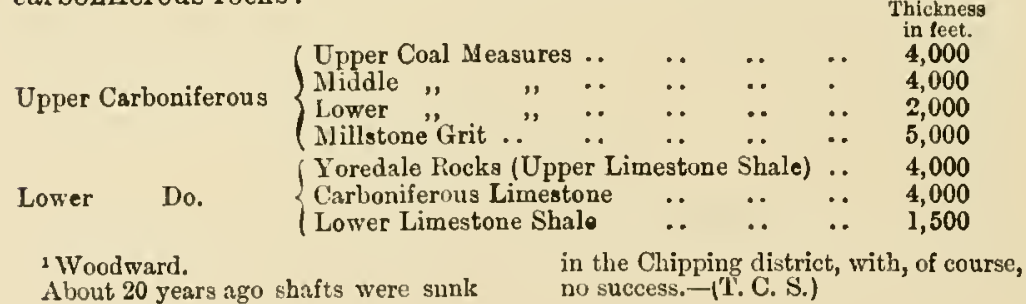


Carboniferous Rocks of the district :-

Upper Carboniferous ...Millstone Grit (part of).

Lower Do. \{Yoredale Rocks.

Carboniferous Limestone.

These admit of further sub-division as follows :-

Millstone Grit Series Third Grit.

\{ Fourth Grit (Kinderscout).

Upper Yoredale (Pendle Grit).

Yoredale Series $\quad\left\{\begin{array}{l}\text { Bowland Shales. } \\ \text { Lower Yoredale Grits. }\end{array}\right.$

Shales and impure Limestone.

Carboniferous Limestone.

By the abuve table it will be seen that the lowest and therefore oldest member of the system in this district is the Carboniferous, or, as it is sometimes termed, Mountain Limestone. It is a massive blue-grey, often crystalline, usually fossiliferous rock. In this district it probably rests on the upturned edges of Silurian beds. It occurs in a continuous band along the north-west flank of the Longridge Fell, and is quarried at Thornley and other places in the vicinity. Farther from home it may be seen on the banks of the Loud, on the banks of the Hodder, from south of Greystoneley to Whitewell, and at Chaigley.

During its formation nearly the whole of the British area was submerged. The nearest mainland to the north of our district was a coastline trending in the direction of a line drawn from the north-west coast of Ireland to near Aberdeen, and forming only a portion of the coastline of a large continent extending to, and probably including, Greenland. To the south a long and narrow ridge extending from the east coast of Ireland to Wales, thence across England to the coast of Norfolk, and probably across the North Sea to Germany, separated us from the southern counties, which were also submerged.

The exact period of this submergence it is impossible even to estimate, but that it must have been of long duration is proved by the fact that during the submergence 4,000 feet of massive limestone was formed from the exuvire of marine organisms, myriads of which may be found embedded in the stone apparently unaltered in form, and, in the case of some of the shells of the mollusca, even rotaining their coloured markings. 
This accumulation took place during a period of gradual depression, due to secular cooling and consequent contraction of the earth's crust, which continued, probably, but with interruptions, during the subsequent deposition of the Yoredale Rocks and the Millstone Grit.

The inhabitants of this vast Carboniferous Sea were numerous and prolific. More than two thousand have heen named. ${ }^{1}$ Of crinoids alone more than one hundred species have been found. In the quarry at Thornley the stems and plates of these curious marine organisms may be found in abundance. The so-called heads or bodies (calyces) also occur, but are far more rare than the stems. The presence of a larger proportion of animal matter may have led to a more rapid disintegration or disarticulation of this part of the animal. (See plate II. fig. 4.)

The crinoids were animals of a low organisation, and were fixed to the bottom of the sea, during a greater part of their existence, by a flexible stem, composed of centrally perforated calcareous discs placed one above another. The so-called head consisted of a globular or pear-shaped arrangement of accurately-fitting hexagonal plates, and ras furnished with five long, branching, feathery arms. The upper surface of these arms, and their branches, carried grooves covered with cilia, the continual vibration of which produced rapid currents of water, bearing oxygen and small living organisms, in the direction of the centrally-situated mouth.

The Crinoidea are now represented by only a few small species. These are found only in tropical seas, aud are gradually becoming extinct. Their fanciful resemblance to plants, their stony structure, and their fixed habit, has carned them the name of "Stone Lilies."

Various species of coral may also be found in the Thornley limestone. The most frequent are Zaphrentis, Clisiophyllum, and Fenestella; the latter appearing like very delicate lace or network.

The presence of these organisms indicates a far higher temperature of sea-water than now obtains in the British area, and this ligh temperature was probably a principal agent in the wonderful development of plant-life that followed, so soon as the land emerged from the waters.

${ }^{1}$ Prestwich. 


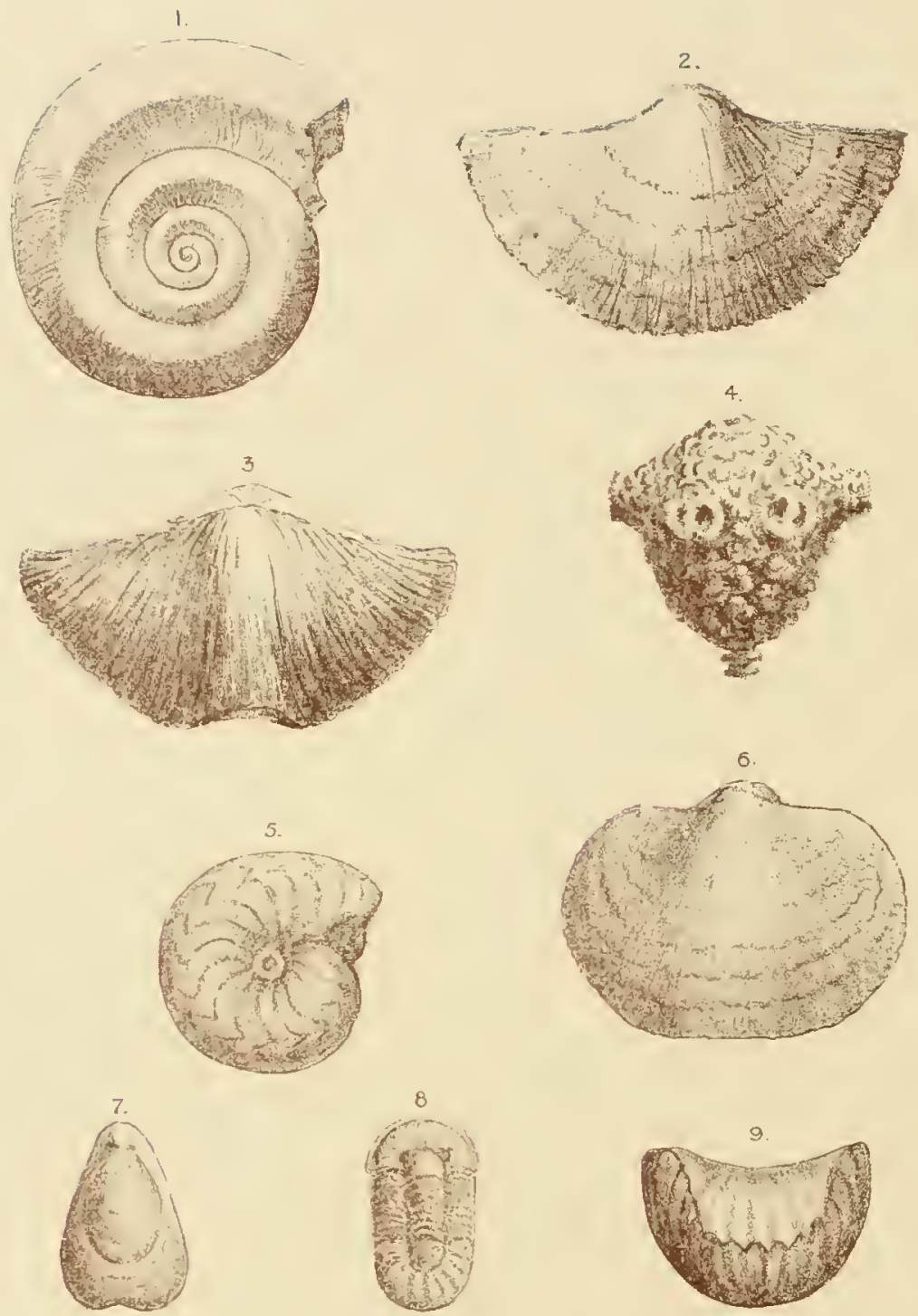

GROUP OF FOSSILS FROM THORNLEY QUARRY.

1 EUOMPHALUS 2 PROOUCTUS 3 SPIRIFERA

4 ACTINOCAINUS 5 GONIATITES 6 ORTHIS

7 TEREBRATULA B TRILOBITE 9 RHYNCHONELLA 
The most numerous of the mountain limestone fossils are the brachiopoda ; almost the lowest family of the mollusca. ${ }^{1}$ They possess a bivalve shell, differing from that of the cockle (Cardium) in that the valves are unequal, and correspond to the dorsal and ventral aspects of the animal. In the cockle and other Lamellibranchs the valves of the shell are equal and correspond to the sides of the animal. These constitute a higher family of the mollusca. Among the genera of the brachiopoda found in the Mountain Limestone the most frequent are Productus (Plate II., fig. 2), Spirifera (Plato II., fig. 3), Terebratula (Plate II. fig. 7), Orthis (Plate II., fig. 6), Rhynchonella (Plate II., fig. 9), Strophomena, Chonetes, and Leptena; most, if not all, of which may be found in the quarry at Thornley.

A fer lamellibranchs, gasteropods, and cephalopods arealso found, such as Conocardium, Euomphalus (Plate II., fig. 1), Murchisonia, and Goniatites (Plate II. fig. 5).

The brachiopods of Carboniferous times gradually died out, and at present are represented in British seas by two species. They were as gradualiy replaced by the higher types, the lamellibranchs and gasteropods, which now number in the same area over three liundred marine species. Another interesting organism found at Thornley is the Trilobite (Plate II., fig. 8). In ages much more ancient than the Carboniferous, the order Trilobita was represented by a great many genera and species. The order gradually dwindlen away and finally died out in the Carboniferous period, where it is represented by four genera and a few dwarfed species, three of which have been found at Thornley.

From the meagre development of the Alountain Limestone in this district we can form no conception of the loveliness of the scenery where it is well developed. It is in Yorkshire and Derbyshire that it may be seen in all its magnificence. There, the eye is delighted with picturesque hills fissured by deel', rugged ravines, and pierced by huge caverns or grottoes whose gloomy interiors are furnished, as if by enchantment, with grotesque imitations of animals and other objects,

${ }^{1}$ It is worthy of note that the mass of this ancient fauna consisted of animals of a low type. The higher types appear. to have been gradually developed with each succeeding deposit. 
and whose roofs are studded with many a crystalline pendant and supported by many a huge pillar, which sparkle and glitter in the light of the explorer's torch. 'There, also, we may revel in lovely dales, the haunt of many a botanical rarity, and carpeted with a short, sweet, green pasture, sure evidence of the fertility of the soil resulting from the denudation of the surrounding rocks.

The Mountain Limestone abounds in economic products. In Derbyshire it yields our principal lead ore and the fluor-spar with which our pottery is glazed. In other localities it yields lead and iron ores and barytes. It is abundantly used for building purposes, for lime-making, and for road-mending. Many of the so-called "marbles" of commerce used for chimney-pieces and other ornamental purposes are fossiliferous Mountain Limestone.

THE YOREDALE SERIES.

Overlying the Carboniferous limestone we find a series of shales and grits, with thin bands of impure limestone and thinner bands of coal.

These beds were named the Yoredale Rocks by Prof. Phillips because of their development at Yoredale, in Yorkshire.

In Lancashire these rocks attain their maximum development of about four thousand feet.

It is a matter of some difficulty to give a satisfactory account of the physical conditions obtaining during the deposition of these rocks. Prof. Green says:- "The mixed deposits of sandstone, shale, and impure limestone, which had at first been confined to the neighbourhood of the shore, now extended over nearly the whole mariue tract, and the deposition of the Yoredale Rocks began. At the same time a slow sinking of the sea-bottom set in, which allowed of these beds being piled one on the top of another to a considerable thickness." Further, he allows that there must have been periods of rest or perhaps of slight upheaval.

Probably, in addition to the above, and in further explanation of the presence of the limestones and coal-seams, there were local areas not undergoing continued subsidence. During the periods of rest, shale and grit were laid down, the sea in these areas became gradually 
silted up, and a growth of vegetation took place. Subsequently these areas were again submerged, and became quiet during the formation of the limestone. This was followed by a second period of rest, silting up, and so on. It requires no great stretch of the imagination to picture this alternation of conditions. To the north and west, on or near the shore of the great north-west continent, there were numerous active volcanoes, as evidenced by the extensive interbedded volcanic rocks of this age in Scotland and Ireland. While these volcanoes were in eruption the sea-bottom would probably undergo depression, but so soon as the pressure was relieved the lava would cease to flow and a period of comparative rest ensue. Without doubt it may be stated that after the deposition of the Mountain Limestone, there was a general but intermuted shallowing of the carboniferous sea, and that during this period the Yoredale Rocks were laid down.

Fossils are of uncommou occurrence in the Yoredale Rocks, but a few species common to the mountain limestone have been found. Longridge Fell, the Bleasdale Fells, Pendle, and Ingleborough, afford examples of the grits of the series, while the shales may be seen in various outcrops over a large tract immediately to the north-west of Longridge.

\section{THE MILLSTONE GRTT.}

This deposit is mainly estuarine, and consists chiefly of a coarse gritty sandstone, with occasional thin seams of shale, coal, and, in some areas, ironstone.

Possibly there was a slight upheaval of the previous submarine area, so that the shallower portions became land, enclosing immense inland seas. Into these seas numerous large rivers rapidly deposited their burden of detritus torn from the older land areas. There is evidence both in the Millstone Grits and the Yoredale Grits that they resulted from the rapid denudation of granitic rocks. Mr. A. J. Jukes Browne has pointed out that the measure of the detritus must be a measure of the land from which it was worn. The Yoredale Rocks and the Millstone Grits taken together give a total thickness of nearly ten thousand feet. The continent from which such a mass of detritus was worn must necessarily have been a large and probably mountainous 
[Chap. 12.

one. Large continents suggest large rivers. The warmth of the Carboniferous sea would give rise to rapid evaporation and produce a copious rainfall. This, again, suggests rapid denudation.

Examination of the grits shows them to be made up of quartzose particles, not much water-worn, with the interstices filled with felspathic matter. The original rocks must therefore have contained these two minerals in large proportions. Such rocks are Granite, Gneiss, and Pegmatite, all of which are included in the term "granitic."

The Millstone Grits have yielded but few fossils, and these are mostly land plants. This, of course, is in itself evidence of the proximity of land. The Lower Millstone Grit occurs on the southern flank of the Longridge Fell. The beds have a general dip to the south-east about fifteen degrees from the horizontal.

The Millstone and Yoredale Grits resist deuudation in a remarkable manner. At the same time the soils derived from them are wet and uuproductive. We thus find them forming hilly country usually covered with peaty bogs or wild moorlands. Among their good qualities may be mentioned the steady yield of good water, and an almost unlimited supply of good building stones. As an example of the latter may be mentioned that for which Longridge is so justly famous.

THE COAL MEASURES.

These beds do not occur in the district, but the better to account for their absence it will be well to give here a short account of their formation.

The doposition of the Millstone Grit completely shallowed the Carboniferous Sea. The whole area became gradually silted up, formiug a series of extensive marshes.

A period of quiescence now set in, duriug which a luxuriant and truly tropical vegetatiou sprang up and accumulated on the marshy ground. Giant Lepidodendrons, Sigillarias, and Calamites, reared their lofty heads above more humble conifers and delicate ferns, while yet the land was scarcely above the sea level.

After this peaceful state had continued sufficiently long to allow an accumulation of several feet of vegetable matter, depression set in and estuarine couditions again prevailed. This was succeeded by another 
silting up, another luxuriant growth of vegetation, another submersion, and so on, with varying intervale, until twelve thousand feet of sedimentary matter had been deposited and nearly one hundred beds of regetable matter had grown and been buried. During the periods of terrestrial conditions there was a gradual development of airbreathing animals. The remains of huge batrachians and of one hundred and fifteen species of insects have been found.

Our largest coalfield is that of South Wales, with an area of 900 square miles. It coutains 75 seams of coal, varying in thiokness from 3 to 9 feet, with a total deptl of 120 feet of coal. The total depth of the strata containing these beds is estimated by Prof. Hull at 11,650 feet. The sane authority, estimating the increase of sediment at two feet in a century, and allowing 1,000 years for the growth of the vegetation required to form three feet of coal, bas calculated that the deposits forming the South Wales coalfield might have been accumulated in 640,000 years.

Shortly after the close of the Carboniferous period, the British area appears to have been subjected to great lateral strain in an easterly and westerly direction. There was a general upheaval of the land, and the Pennine Range was formed. At the same time, or later, there appears to have been a lesser strain exerted at right angles to the main one, and this resulted in the formation of a series of smaller anticlines, branching from the central one. In the hollows between these hills, inland seas and lakes were enclosed, in which were deposited the red sandstones and magnesian limestones of the Permian System. One of these lakes probably extended over the whole of the north of England and embraced parts of the south of Scotland. Portions of the deposits have, however, been subsequently removed by denudation, and other portions are covered by more recent deposits. None occur near Longridge, but the red sandstones occur near Brock Railway Station, at Garstang (see Plate 1), and a small patch at Roche Bridge, near Walton-le-Dale. During Permian times, and subsequently, the coal-measures, wherever they covered the recently-formed hills, were favourably exposed to the utmost forces of atmospherio denudation, while those portions which formed the low-lying lands, 
[Chap. 12.

besides being less exposed to denudation, were in many instances buried beneath a protective covering of detritus worn from the high lands.

Thus it is we find our coal-measures occurring in isolated synclinal areas, which represent the ancient valleys. Our district then formed part of the high exposed land. The coal-measures, together with a fow of the underlying beds, have been removed by denudation, leaving the older rocks exposed to view.

If the British area had been simply upheared, and not puckered into hill and valley, after the deposition of the coal-measures, there would not now remain a restige of coal in our land. The whole would have been removed by the action of the meteorological forces during the ages that have lapsed since the coal was formed.

When we consider all that coal has done for Britain, and all that would happen if even now our supply were to fail, we have reason to be thankful that our country has not always been so free from subterranean disturbance as ir is at present.

\section{SECONDARY ROCKS.}

The sole representative of these rocks in our district is the Pebble Beds of the Bunter, almost the oldest of the Mesozoic formations. It occurs in a large tract from Myerscough in the north-west, to Bamber Bridge in the south-east, and includes Grimsargh and Penwortham in its shorter diameter.

The rocks are practically unfossiliferous if we except the fossils of older rocks occasionally found in the pebbles. These are sometimes of well known species, and lead to the identification of the rock from which the pebble was worn. The Bunter is celebrated for its waterbearing properties. In fact it is said that boring for water in these rocks has never proved unsuccessful.

During the deposition of the newer mesozoic rocks our district had a varying fortune of land and sea area, but whatever deposits occurred they were subsequently removed by denudation.

TERTLARY ROCKS.

These are unrepresented in this district. Land prevailed probably over the whole of the north of the British area. 


\section{QUATERNARY DEPOSITS.}

Perhaps the most remarkable of our local deposits is that found, almost invariably, covering the older solid rocks. The surface soil rests upon drift sands or gravel, or upon a dull, red clay, which is sometimes of great depth, and contains numerous rounded stones, often polished and striated in a characteristic manner. This tells us of a time when by some remarkable distribution of land and sea, or a still more extraordinary cosmical change, our country, together with the whole of Northern Europe, endured a climate as arctic as that of Greenland to-day. Probably the whole of England north of the Thames was covered by a huge ice-sheet. The British Alps were occupied by extensive snow-fields, from which radiated numerous glaciers. These latter traversed the valleys and lowlands, scoring and abrading the solid rocks and forming a fine impalpable mud, which was deposited wherever the conditions were favourable.

This rigorous climate continued sufficiently long to allow a deposit in some areas of 200 feet of this Lower Boulder Clay. Then followed a more genial period. The land was partially submerged, the ice melted, and the drift-deposits were spread on the surface of the clay. These consist of sands and gravels, with a maximum depth of 50 feet, containing marine shells, the majority of which are iclentical with the shells of species of mollusca still existing on the Lancashire coast.

The drift-deposits are found from the sea-level in some localities, up to 1,400 feet altitude in other's. Therefore the laud must have been submerged until only the summits of our highest hills were above water. Subsequently the land partly emerged and a second glacial period began, though less serere than the former. Again our hills were covered with snow and our valleys filled with glaciers. Some of these glaciers reached the sea, and discharged their streams of muddy water over the submerged areas and the Upper Boulder Clay was formed. Icebergs and ice-rafts floated about, travelling for great distances laden with cargoes of rocky debris torn from the higher lands. When the bergs and rafts melted, this cargo was precipitated upon the muddy bottom many miles from its parent rock. We thus find erratic 
boulders and pebbles associated with the boulder clay, differing altogether from the rocks of the neighbourhood. In the recent excavations connected with the Ribblo Dock, pebbles or boulders of the following rocks were found :-

$\begin{array}{ll}\text { Granites, } & \text { Agglomerates, } \\ \text { Diorites, } & \text { Volcanic Tuff, } \\ \text { Porphyrites, } & \text { Carboniferous Limestone. } \\ \text { Quartzites, } & \text { Ganister, }\end{array}$

and several others still undetermined. The nearest locality for any of the above named igneous rocks is in the extreme north-west of Lancashire, but probably some of the stones were brought from even greater distances.

The Glacial Deposits are well developed in the Longridge district, and may be seen in sections at various places along the banks of the Ribble, notably at Ribchester, where the fossils of the Drift are obtainable. Visitors to Blackpool during the summer nonths may spend a profitable hour in collecting shells from the Drift Gravel of the cliff immediately below "Uncle Tom's Cabin." These may then be compared with the shells of existing species found on the shore at low water, and with those found in the gravels at Ribchester.

Resting upon the surface of the Boulder Clay there is usually a more recent deposit. This may consist of alluvium, of peat, of river gravel, or it may be simply the insoluble detritus worn from the surrounding rocks and spread over the land by the action of running water, wind, \&c. It is generally of a dark colour, owing to the presence of decaying organic matter, and forms the soil upon which the vegetation of the district is developed. 



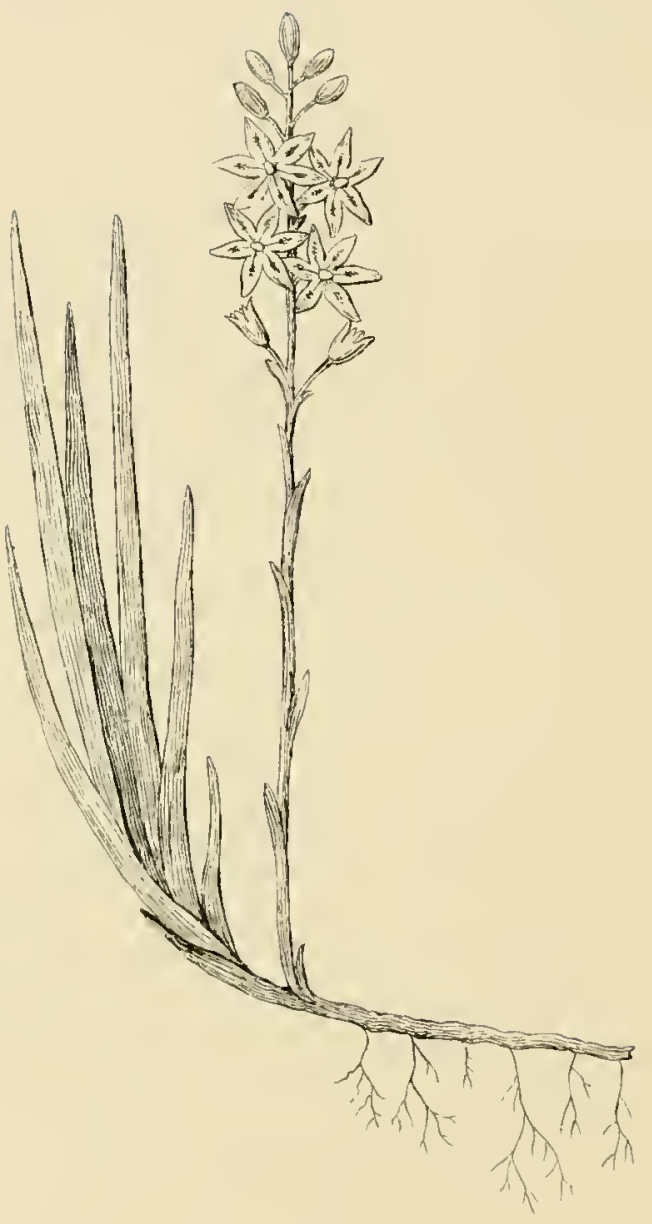

THE LANCASHIRE ASPHODEL 


\section{Botany cF the District.}

To the lover of nature there are few studies so attractive, so absorbing, and so satisfying, as the study of our native plants. Doubtless this is in a measure due to the health-giving nature of the pursuit. Our army of botanists is recruited chiefly from among those who are confined to cities or towns during a greater part of the year The diversity of scenery encountered in the search for objects in themselves of infinite variety of form and colouring, the necessity for extra muscular exertion, the little difficulties to be overcome, and the inspiration of an unwonted supply of exygen, combine to give such elasticity to the spirits that a new "find" is all that is necessary to produce a flutter of pleasurable excitement very beneficial to the health of those whose ordinary duties are of a sedentary character.

$$
\begin{aligned}
& \text { "A primrose on the river's brim, } \\
& \text { A yellow primrose is to him, } \\
& \text { But it is something more." }
\end{aligned}
$$

For obvious reasons the botanist's excursions are usually made during the sunny months, when the decorative goddess is most lavish. It is then her votaries may be seen in wood and meadow, on mountain side and summit, by brook and lake, in shady dell and deep ravine, loading their vasculums with her choicest offerings.

But there are no reasons, other than those of weather and the exigencies of business, why the study of botany in the field should be confined to the summer months. It should be continued whenever opportunity occurs during every month of the year. Many of our rarer plants are found in flower only in early spring, others again only in late autumn; while quite one-half of our cryptogams are at their best between October and April. To those who would enrich their collections with specimens of these more humble, but not less beautiful and interesting members of our flora, the walls, woods, and moors of Longridge Fell will well repay a thorough search during the colder months of the year.

In the autumn the woods abound with fungi of exquisite shades of brown, red, yellow, and purple. The gaudy Russula emetica and the beautiful scarlet Peziza aurantia were quite abundant here in 1883 . Several of the esculent species also occur, and in numbers sufficient to 
afford a good dish. Of these the most notable are Boletus edulis, Clitocybe nebularis, C. dealbatus, and the much-lauded Lactarius deliciosus, of which Sir J. Smith has written, "it really deserves its name, being the most delicious mushroom known."

During winter and early spring the walls and rocks in the district are covered with mosses and hepatics, in fruit, for which we would seek in vain during the hot weather.

Although our district cannot boast the presence of many rare flowering plants, we have an abundance and great variety of the more common species. The absence of the less common species is due partly to the character of the soil, and partly to the physical geography of the district. Certain plants thrive, and are therefore found in their wild state, upon calcareous soils, others upon peaty or boggy soils, and others again upon sandy or clayoy soils. Some choose a dry situation, while other's revel in moisture, or are altogether aquatic in habit. Some flourish in elevated and exposed situations, and others only where they may be sheltered from fierce wintry winds or the scorching rays of the midday sun.

In a given short radius from Clitheroe a greater number of botanical species will be found than in a similar area with Longridge as centre. This is due to greater fertility of soil and greater variety of habitat afforded by the former area, owing to the preseuce of the Carboniferous Limestone in fair abundance at or near the surface. The soils, if not themselves derived from or overlying the limestone, aro irrigated by water containing it in solution. Chemical analyses show that lime in some form is absolutely necessary to the life of most plants, and that many contain it in large proportion. Some, indeed, are not content with the lime required by their internal economy, but, in addition, secrete a thick layer upon their exteriors until not a vestige of the green matter of the plant is visible.

The highlands of our district are of grits, and the water yielded by these, although excellent as a potable article, is less so as a fertiliser. Moreover, the soils derived from these rocks are cold and uncongenial to many plants that may be considered fairly common in most localities. 
Notwithstanding the disadvantages indicated, a thorough systematic working of the district will afford a fair collection of our native plants, more especially of the moisture-loving species, and very fow of the orders will be unrepresented. Spring, summer, autumn, and winter will each furnish its quota, and find ample employment for the leisure hours of the mest ardent student.

Starting from the railway station for a day's botanising on the Fell, the first peint of interest will be the wall on the right hand near the quarry on Tootle Height. Quite a collection of mosses may be made here. Of these we may mention Weissia viridula, Dicranella heteromalla, Didymodon rubellus, Barbula unguiculata, B. convoluta, Grimmia apocarpa, Gymnostonum microstomum, Grimmia pulvinata, Syntrichia subulata, Encalypta streptocarpa, Pytchomitrium polyphyllum, Homalothecium sericeum, Brachythecium velutinum, B. rutabulum, Rhynchostegium coufertum, R. murale, and var. complanatum, Amblystegium serpens, Hypnum cupressiforme, \&c., \&c.

Entering the quarry, the first notable plant is the Genista tincteria, valued at one time for its yellow dye. Next the blue heads of Jasione montana rivet the attention. Later, Leontodon hispidus, Cardamine hirsuta, Hieracium vulgatum, and a spray of the bright yellow flowers of Cytisus scoparius may be added to our collection.

Proceeding eastward from the quarry, and risking a charge of trespass, we find in the corner of a meadow a splendid clump of Geranium phœum with its khowy, deep purple, flowers; and beside a spring a few dwarf specimens of Mimulus luteus, which we leave untouched in the hope that it may spread, because it is one of our rarities.

Turning now along a lane and heading for the Fell we find first the blue bells of Campanula rotundifolia, next Polygala vulgaris, Luzula multiflora, Digitalis purpurea, and Lomaria spicant. Higher up the hill we find, in wet places, Juncus acutiflorus, J. lamprocarpus, J. nigritellus, J. bufonius, Pedicularis sylvatica, Carex divulsa, C. paniculata, C. binervis, C. ovalis, C. fulva, Peplis Portula, Lychnis floscuculi, Epilobium montanum, and Galium Witheringii. On the moors we add to our stock Potentilla Tormentilla, Polygala depressa, Vaccininm myrtillis, V. Oxycoccus, Euphrasia officinalis, Galium saxatile, 
Erica tetralix, E. cinerea, and Calluna erica. From the boggy places we obtain Viola palustris, Hypericum tetrapterum, the carnivorous Drosera rotundifolia, a viviparous variety of Festuca ovina, Epilobium palustre, Eriophorum angustifolium, Carex stellulata, C. glauca, and a plentiful supply of the golden starry spikes of the Lancashire Asphodel-Narthecium ossifragum. The specific name of this plant has its origin in a supposed property of softening the bones of the cattle that eat it.

In the woods and plantations on the Fell sides and in the vicinity, we have obtained at various times Anemone nemorosa, Arum maculatum, Mercurialis perennis, Scilla nutans, Cardamine amara, Lychnis diurna, Geum urbanum, Carex sylvatica, Bromus asper, Oxalis acetosella, Stellaria Holostea, and Allium ursinum, with its beautiful starry blossoms and its valiant odour. The English name of this plant is "Ramsons," and it was evidently at one time considered to possess excellent medicinal properties, for an old rlyyme runs :-

Eat leeks in March and ramsons in May,

All the year after the doctor may play.

In a walk from Longridge to Chipping a good addition may be made to the number of our specimens. The most notable are Campanula latifolia, Salix pentandria, S. viminalis, Bromus mollis, Adoxa moschatellina, A. caryophyllea, Briza media, Poa trivialis, Vicia cracca, Trifolium dubium, Geranium dissectum, G. molle, G. Robertianum, G. lucidum, Crepis virens, Hieracium boreale, Pulicaria dysenterica, Rumex viridis, Polypodium vulgare and Asplenium rutamuraria. The latter grows in abundance on the churchyard wall at Chipping. We have been told that Ceterach officinarum grows on a certain wall near the same village, but have not verified the statement.

If our walk be extended to Whitewell some rarer plants may be added, such as Pinguicula vulgaris, Myrrhis odorata, Chrysosplenium alternifolium, Sagina uedosa, Scirpus fluitans, Equisetum sylvaticum, Glyceria plicata, Rauunculus Lenormandi, Agrimonia odorata, Iistera ovata, Orchis Morio, Epipactis latifolia, Scrophularia Balbisii, Veronica Anagallis, and several mosses and hepatico. A day on Parlick will furnish the bryologist witl Climacium dendroides, Hyocomium flagellare, Eurhynchium myosuroides, E. striatum, E. piliferum, E. prælongum, 
Brachythecium populeum, B. plumosum, Fissidens taxifolius, Neckera complanata, Orthotrichum rivulare, Mnium affine, M. cuspidatum, Fontinalis antipyretica, \&c., \&c., and several hepaticæ.

The most profitable walk for the collection of flowering plants is from Longridge to Ribchester, and thence up along the banks of the Ribble. Soon after leaving Longridge, the hedge on the loft hand side of the road will afford specimens of Pyrus latifolia. A little farther along, on the opposite side, a ditch will furnish a beautiful crisp-leaved Mentha, but hitherto without flowers. In various places during the walk we shall find Hypochæris radicata, Medicago Jupulina, Lamium maculatum, Viola Reichenbachiana, Cynosurus Cristatus, Trisetum flavescens, Dactylis glomerata, Pimpinella magna, and Veronica Beccabunga. If we examine the plots of cultivated and waste ground we shall meet with Malva borealis, M. sylvestris, Viola tricolor, $\nabla$. arvensis, Fumaria Boræi, Lamium amplexicaule, Chenopodium album, Myosotis arvensis, Polygonum persicaria, P. lapathifolium, P. aviculare, Papaver Rhreas, Melilotus officinalis, Spergula arvensis, Agropyron caninum, Bromus sterilis, Urtica dioica and others. As we near Ribchester Bridge the hedgebanks are bright with the saucy blue flowers of Veronica Chamodrys and its more modest sister V. serpyllifolia. Here, we may also gather Origanum vulgare, Bartsia verna, Trifolium medium, T. repens, and two varieties of Rosa canina. Along the banks of the river, Barbarea vulgaris, Brassica Napus, Silene inflata, Poterium sanguisorba, Tilia intermedia, Prunus padus, P. Avium, Ulmus campestre, Acer campestre, Pyrus Aucuparia, Alnus glutinosa, Polystichum lobatum, P. angulare, Lastræa spinulosa, Valeriana officinalis, Stellaria nemorum, Orchis maculata, Myosotis sylvatica, Calamintha Clinopodium, Plantago media, Carex pendula, C. riparium, Saponaria officinalis, Senecio saracenicus, Cardamine flexuosa, Knautia arvensis, together with many of those mentioned in connection with the other excursions.

The ponds and ditches of the district have yielded Caltha palustris, Nfmphæa alba, Mentha hirsuta, M. sativa, Galium uliginosum, Alisma plantago, Typha latifolia, Enauthe crocata, Myosotis palustris, M. crespitosa Lemna trisulca, L. minor, L. gibba, Polygonum 
amphibium, P. hydropiper, Cares remota, C. Goodenowii, Sparganium ramosum, S. simplex, Potamogeton natans, P. pusillus, P. rufescens, Comarum palustre, Menyanthes trifoliata, Ranunculus hederaceous, $R$. Flammula and Stachys palustris. The latter plant is the Woundwort of the herbalist. It is credited with the property of healing wounds in a remarkably rapid manner. Gerard says of it:- "The leaves heerof stamped with Axungia, or Hogs greaso, and applied vnto green wounds in maner of a pultis, doth heale them in such short time and in such absolute maner, that it is hard for any that hath not had the experience thereof to beleeve: for being in Kent about a Pacient, it chanced that a very poore man in mowing of Peason did cut his leg with the Sieth, wherein he made a wound to the bones, and withal very large and wide, and also with great effusion of bloud, the poore man crept vnto this herbe, which he brused in his hands and tied a great quantitie of it vnto the wound with a peece of his shirt, which presently stanched the bleeding and ceased the pain, insomucl that the poore man presently wont to his daies work againe and so did from daie to daie, without resting one daie untill he was perfectly hole, which was accomplished in a fewe daies by this herbe stamped with a little Hogs grease, and so laid upon in maner of a pultis, which did as it were glewe or soder the lips of the wounde togither, and heale it according to the first intention (as we tearme it) that is without drawing or bringing the wounde to suppuration or matter, which was fully performed in seaun daies, that woulde have required fortie daies with Balsam itselfe. I sawe the wounde, and offered to heale the same for charitie, which he refused, saying, that I could not heale it so well as himselfe; a clownish answer I confesse without thankes for my 'good will, whereupon I have named it Clounes Woundwort as aforesaide," - a name it bears to this day.

Many other interesting and profitable excursions may be made in addition to those suggested, but the space allotted will not admit an account of them all. With an increasing redius of course a greater number of species will be found. The dingle near Hurst Green will afford a good day's botanising; Eupatorium cannabinum, Pterygophyllum lucens, Equisetum maximum, Lepidoza setacea, and many other good 
things. The entomologist also will find this dingle well worth a visit. A special journey should be made to Goosnargh for a specimen of Tulipa sylvestris, which abounds among the grass under the trees in some orchards.

In the foregoing account no mention is made of many common plants of frequent occurrence in the district, but a list is appended which contains the uames of all the species gathered or noted by the writer. It must not be assumed that the list represents a complete flora of the district. It is simply the result of several excursions made between the latter part of the year 1880 and the summer of 1888 .

\section{A List of Plants found in the Vicinity of Longridge.}

\section{PHANEROGAMIA.}

Ranunculace-

Anemone nemorusa

Ranunculus fluitans

$$
\begin{array}{ll}
, & \text { peltatus } \\
, & \text { Ienormandi } \\
, & \text { hederaceus } \\
, & \text { Flanimula } \\
\text { ", } & \text { bulbons } \\
, & \text { acris } \\
\text { ", } & \text { Ficaria }
\end{array}
$$

Calthä palustris

NYMPHEACEM-

Nymphæa alba

Papaveraces-

Papaver Rhreas

Funarice dubium

Fumaria pallidiflora var: Burcei

Crucifere officinalis

Nastortium officinale

Barbarea rulgaris

Arabis sagittata

Cardamine amara

$$
\text { , pratensis }
$$$$
\text { " lirsuta }
$$

". flexuosa

Cochlearia officinalis

Sisymbrium officinale

Brassica Napus

", Rinapis
Cruciferce-continued- -

Capsella Bursa-pastoris

Lepidium campestre

Raphanus Raphanistrum

VIOLARIEA-

Viola palustris

"s sylvatice

", var : Reichenbachiana

" canina

", tricolor

", arvensis

", arvens

Polygala rulgaris

Carpyllacea

Saponaria officinalis

Silene inflata

" vă : puberula

Lychnis alba

, diurna

" Flos-cuculi

Cerastium semidecandrum

" glomeratum

Stel" triviale

tellaria newornn

", media

, Holosten

", graminea

", $\quad$ graminea

Sagina apetala

", procumbens

Spergula arvensis

Portulace

Iontia fontana 


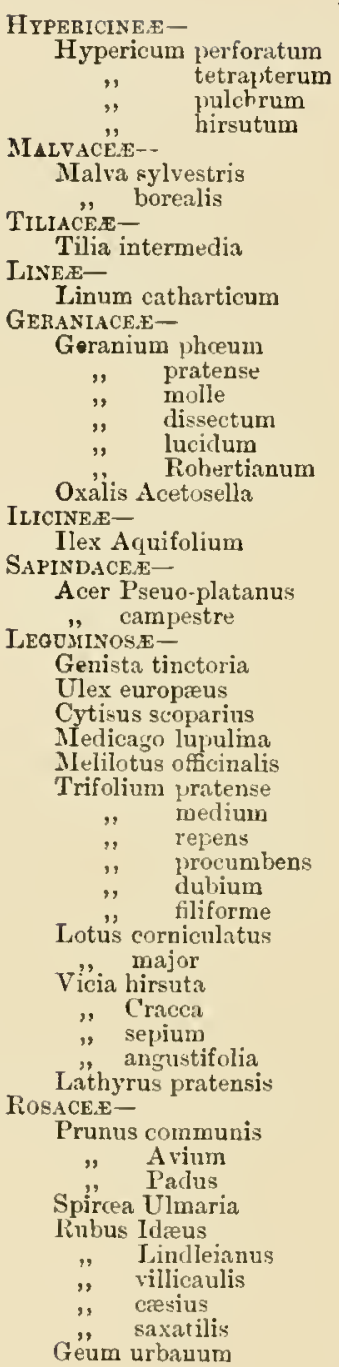

"' major

" saxatilis

Phanerogamia. - Continued.

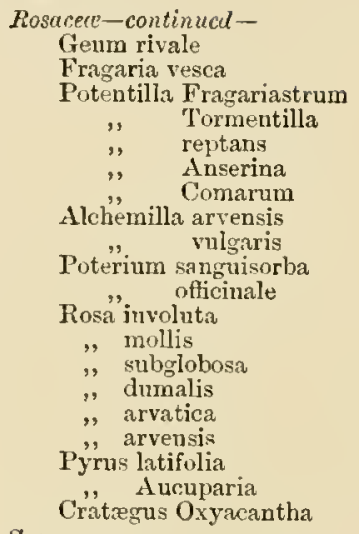

Saxifrage.e-

Chrysosplenium oppositifolium

Droserace alternifolium

Drosera rotundifolia

HaLORAGEE-

Callitriche vernalis

" stagnalis

LYTHRARIE.E-

Peplis Portula

ONAGRARIE.s-

Epilobium hirsutum

$$
\begin{array}{cc}
\text {," } & \text { parviflorum } \\
, " & \text { montanum } \\
, " & \text { tetragonum }
\end{array}
$$

Circea lutetiana

UMRELLIFERE--

Hydrocotyle vulgaris

A pium nodifforum

Agopdium Podagraria

Pimpinllea Saxifraga

" magna

Conopodium denudatum

Anthriscus sylvestris

Enanthe crocata

Ethusa cynapium

Angelica sylvestris

Heraclenm Spliondylium

Dauens Carota

Torilis Anthriscus

ARALIACEN-

Hedera Helix- 
Caprifoliaces-

Adoxa Moschatellina

Sambucus nigra

Lonicera Periclymenum

livblacei: -

Galium C'ruciata

verum

", saxatile

", Witheringii

", uliginosum

, A prine

Aspernla odorata

Sherardia arvensis

VALERIANEF-

Valeriana dioica

DIPSACE ",- officinalis

Scahiosa suceisa

Composita- arvensis

Eupatorium cannabinum

Solidago Virgaurea

Bellis pereunis

Gnathalinm uliginosum

$$
\text { , sylvaticum }
$$

Pulicaria dysenterica

Achillea Millefolium

Ptarmien

Chrysanthemum Leucanthemum

Matricaria inodora

Artemesia vulgaris

Tussilago Farfara

Petasites vulgaris

Senecio vulgaris

$$
\text { " sylvaticns }
$$

Jacolæa

,. aquaticus

, a alacenicus

Arctinm ninus

Carduns nutans

Cnicus lanceolatus

, I'alustris

" arrensis

Centaulea nigra

Japsana commun is

Crepis virens

pajudosa

Hieracium Pilosella

$$
\text { " vulgatum }
$$

Hypochæris radicata

Leontodon liirtus

$$
\text { , hispidus }
$$$$
\text { autumnalis }
$$

Taraxacum Deus-leonis
Phanerogamia,-Continued.

Composite-continuedJactuca muralis Sonchus oleraccus

', asper

Tragopogon pratensis

CaMPaNUlaces-

Jasione montana

C'anpamula latifolia

VACCINIACEArotundifolia

Vaecinium Oxyenceos , Vitis Idra

Ericace" Myrtillus

Calluna Erica

Erica Tetralis

Prung cinerea

Primula vulgaris

" veris

Lysimachia Nummularia

A naganglis arvensis

OLEACEE -

Fraxinns excelsior Ligustrum vulgare

Gentianes-

Erythrea Centaurium

Menvanthes trifoliata

BORAGINEA-

Myosotis cespitosa

$$
, \text { palustris }
$$

". sylvatica

", arvensis

CoNTolvouncer-

Calystegia Sepium

SOLANACER-

Solauum Julcamara

ScrophULARINE. -

Scrophularia Balbisii noclosa

Mimulus lutens

Jigitalis purpurea

Veronica hederefolia

" polita

", agrestis

" arvensis

, serpyllifolia

officinalis

", Chamedrys

" montana

, Anagallis

, Beccabuuga

Emphrasia ofticinalis 
[CH $\triangle \mathrm{P}, 12$,

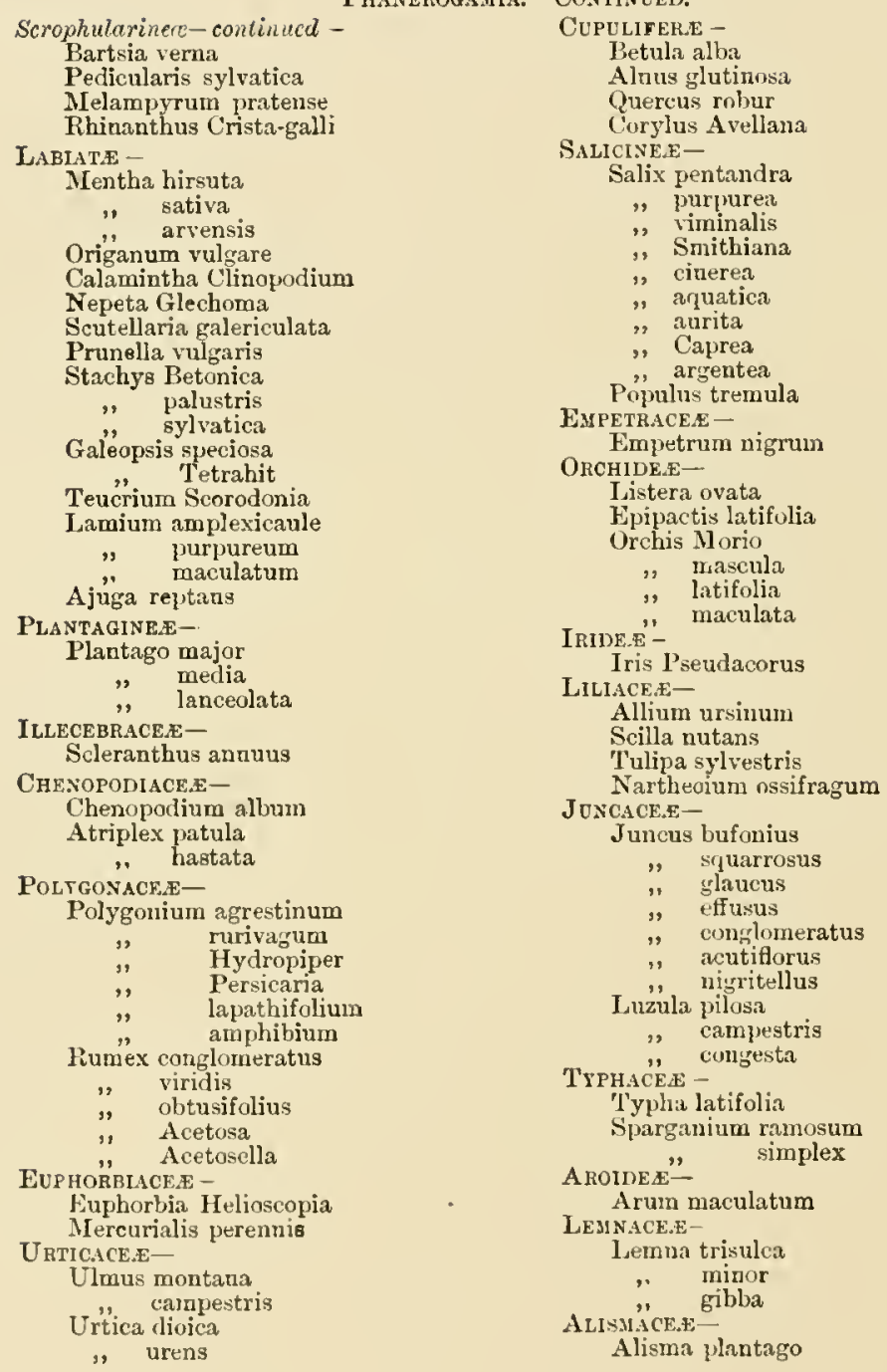




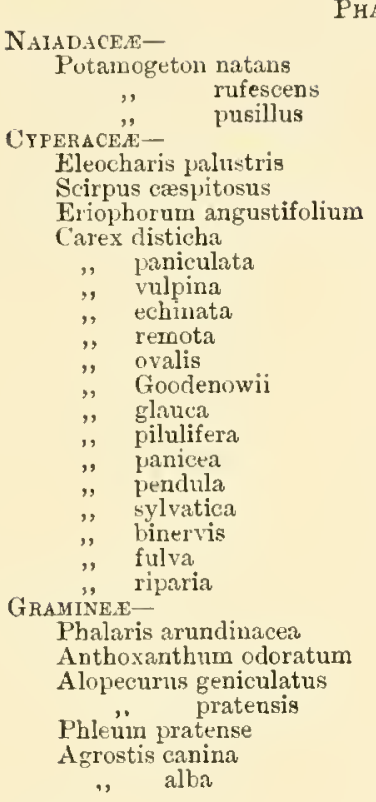

Filices-

Pteris aquilina Lomaria Spicant Asplenium Trichomanes Ruta-muraria Athyrium Felix-fomina Polystichum lobatum

angulare Phanerogania. - Continued.

Gramince-continuedAerrostis vulgraris

Aira caryophyllea

, coespitosa

"flexuosa

Holeus mollis

" lanatus

Avena flavescens

" pubescens

Arrhenatherum avenaceum

Poa annua

", pratensis

"trivialis

Cynosurus cristatus

Molinia corulea

Dactylis glomerata

Briza media

Glyceria fluitans

," plicata

Festuca ovina

," duriuscula

,, elatior

Bromns asper

", sterilis

" mollis

Brachypodium sylvaticum

Lolium pratense

, italicum

Agropyron repens

Nardus stricta

CRYPTOGANIA.

Characere-continued-

Nitella opaca

Musci-

$$
\begin{gathered}
\text { Sphagnum acutifolium } \\
\text { ", cuspidatum } \\
\text { cymbifolium } \\
\text { Phascum cuppidatum } \\
\text { Pleuridium subulatum } \\
\text { Gymnostomum microstomum } \\
\text { Weissia viridula } \\
\text { Dicranella varia } \\
\text { Dicrinum scoparium } \\
\text { Leucobryom glaucum } \\
\text { Ceratodon purpureus } \\
\text { Campylopus pyriformis } \\
\text { Pottia trumcatula } \\
\text { Didymodon rubellus } \\
\text { Ditrichum homomallum } \\
\text { Barbula rigida }
\end{gathered}
$$

Polynodium v

Equisetace开-

Equisetum maximum

$$
\begin{array}{ll} 
& \text { arvense } \\
, & \text { sylvatioum } \\
, & \text { yalustre }
\end{array}
$$

LTCOPODIACEEimosum

Lycopodium Selago

Characezi-

Chara vulgaris 
Musci-continued-

Barbula muralis

"unguiculata

". convoluts

" revoluta

" fallax

"'subulata

Eucalypita streptocarpa

Grimmia apocarja

$$
\text { pulvinatá }
$$

Racomitrium aciculare

$$
\text { ", lanuginosum }
$$

" heterostichum

Ptychomitrium polyp
Orthotrichum affine

$$
\text { , rupestre }
$$

Tetraphis pellucida

Atrichum unchlatum

Pogonatum aloides

Polytrichum commune

$$
\text { ", jiliferum }
$$

Aulacomnion palustre

Leptolorym pyriforme

Webera nutans

, aunotina

, carnea

Bryum pallens

" capillare

", coesjiticiun

orenteum

Mñum cuspidatum

$$
\text { ", aftine }
$$

", rostratum

serratum

", bornum

", undulaturn

punctatum

Iunaria hyrometrica

Physcomitrium pyriforme

Bartramia funtana pomiform

Fissidens viridulu

$$
\text { " } \quad \text { bryoides }
$$$$
\text { " adiflins }
$$

Glimacium dendroiles

Fontiualis antipyretica

Necliera complanata

Thuidium tamarixcinum

Homalothecium sericeum

Prachytlecium velutinum

$$
\text { " rutabulum }
$$

Cryptogania.-Continued.

IIusci-continued-

Brachythecium populeum

" plumosum

Scleropodium expositum myosuroides

$$
\begin{array}{ll}
, " & \text { striatum } \\
, & \text { piliferum } \\
, & \text { prelongum } \\
\text { Swartzii }
\end{array}
$$

Hyocomium flagellare

Riliynchostegium confertum

$$
\begin{gathered}
\text { ", murale } \\
\text {," var : oom. } \\
\text { ruscifolium }
\end{gathered}
$$

Plagiotliecium denticulatum$$
\text { , sylvaticum }
$$$$
\text { " undulatum }
$$

Amblystegium serpens

$$
\text { , irriguum }
$$

Hypunn stellatum

$$
\begin{array}{ll}
\text { ", } & \text { folygamum } \\
\text { fluitans } \\
\text { ", } & \text { revolvens } \\
\text { filicinum } \\
\text { ", } & \text { cupressiforme } \\
\text { molluscum } \\
\text {," } & \text { cuspidatum } \\
\text { purum }
\end{array}
$$

Hylocomium splendens

$$
\begin{array}{ll} 
& \text { squarrosum } \\
" \text { triquetrum } & \text { loreum }
\end{array}
$$$$
\text { HePatic }
$$

Marchantia polymorpha

Conocejhalus conicus

Ricciella fluitans

Frullania Tamarisci

Lejeuuea minutissima

serpyllifoli

Radula complanata

Lepidozia reptans

$$
\text { setacea }
$$

Cevhalozia divaricata

$$
\begin{array}{ll}
" & \text { bicuspidata } \\
" & \text { convifolia } \\
, & \text { connivens }
\end{array}
$$

Lophocolea bidentata

Trichocolea tomentella

Blepharozia ciliaris

Blepharostoma trichophyllum

Scapania undulata

$$
\text { , nemornsa }
$$

" curta 
Chap. 11.]

Hepaticre-continuedDiplophyllum albicans Alicularia sealaris

Plagiochila asplenioides

Jungermannia crenulata

" sphærocarpa

", cordifolia

" riparia

" inflata
Criptogamia.-Contunued.

Hepatice-continual-

Jungermannia ventricosa

", intermedia

" incisa

Pellia épiphylla

Aneura pinguis

", multifida

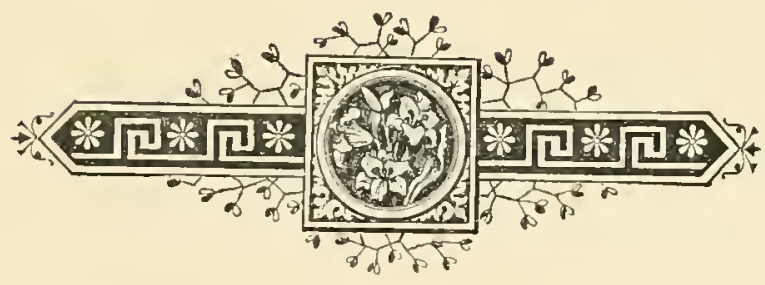




\section{APPENDIX A.}

Church Brief.-Dilworth. ${ }^{1}$

George the Fourth, by the Grace of God, of the United Kingdom of Great Britain and Ireland, King, Defender of the Faith. 'To all and singtiar Archbishops, Bishops, Archdeacons, Deans and their officials, Parsons, Vicars, Cnrates, and all other Spiritual Persons, and to all Teachers and Preachers of every separate congregation, and also to all Justices of the Peace, MIayors, Sherifis, Bailiff, Constalyles, Churchwardens, Chapelwardens, Headboroughs, Collectors for the Poor and their Overseers, and also to all officers of Cities, Boroughs, and Towns-corporate, and to all other our Officers, Ministers and Snbjects whomsoever they be as well within Liberties as withont to whom these Presents shall come, oreeting. Whereas it bath been,represented unto us as well upon the humble Petition of Wiliam Strickland, Richard Pinder, John Bennett, and William Bennett, of Dilworth, in our County Palatine of Lancaster, as by Certificate under the hands of Our trnsty and well-beloved Justices of the l'eace for Our County Palatine nf Lancaster assembled at their General Quarter Sessions of the Peace held at Preston in and for Our said County on the Twelfth Day of January in the Sixth yoar of our lieign. That on the Thirteenth day of October in the Fifth year of our Reign, a sndden and terrible Fire broke out in the Building used as 'Turners' Workshop and Premises sitnate in Dilworth, in Onr County Palatine of Lancaster, which, in a short space of time, destroyed the entire Building with the whole of the Machinery, going Gear, Work Tools, Tizbber, and other 'l'hings which were therein the said Building, being the Property of William Strickland, and the said Machinery, going Gear, Work Tools, Timber and other Articles being the property of Richard Pinder, John Bennett, and William Bennett, the Occupiers of the said Building, by which dreadful Calamity the said William Strickland, Richard Pinder, John Bennett, and William Bennett are respectively reducell to great difficulty and distress, the truth of which was shewn to Our Justices at their General Quarter Sessions held at Preston on the Day aforesaid by the Oatlis of the poor Sufferers and also of Robert Strickland and Thomas Wilcock, credille and experienced persons, who were well acquainted with the Premises at the time this misfortune happened, and who have marle an estimate of the loss sustained, which nnder a moderate computation amounts to the snm of 'Three humdred and forty-eirht pounds seventeen shillings and fourpence. The said poor sufferers have most humbly besonght us to grant unto them Our most gracious Letters Patent, Licence and Protection, under our Great Seal of Great Britain, to empower them to ask, collect, and receive the Alms, Benevolence, and charitable ('ontributions of all Our loving Subjects throughout England, Our 'Towu of Berwick-upon.'Tweed, and Our Counties of Flint, Denbigh, and Radnor, in Wales, and from House to Honse thronghout our Connties Paiatine of Lancaster and Chester and Our Counties of York and Derby, for the relief of the said poor Sufferers. Unto which their humble Fequest We have graciously condesceuded not doubting but that when these Presents

1 From the original in Brit. Musenm. l'riefs at one time were very common; and appear to have hal their origin in the Papal briefs. 'I'hey were subject to (nent abuse, and were finally abolished in 18\%3. The copy of the hrief here given would be one of the latest issued. 
elall be known by Our loving Subjects they will readily and cheerfully contribute their Endeavours for accomplishing the same. Know ye therefore that Our special Grace and Favour We have given and granted and by these Our Letters Patent, under Our Great Seal of Great Britain, We do give and grant unto the said poor Sufferers, and to their Deputy and Deputies the Bearer and Bearers hereof authorized as is herein after directed full Power, Licence, and Authority to ask, collect, and receive the Alms, Benerolence, and Charitable Contributions of all Our loving Subjects within all and every Our Counties, Cities, Boroughs, Towns, priviledged Places, Hamlets, Cinque Ports, Districts, Parishes, and all other Places whatsoever throughout England, Our Town of Berwick-upon-Tweed, and Our Counties of Flint, Denbigh and Radnor, in Wales, and from House to House throughout our Counties Palatine of Lancaster aud Chester, and Our Counties of York and Derby for the purpose aforesaid. And therefore in pursuance of the Tenor of Our Act of Parbament, and in the Fourth Year of the Reign of the late Queen Anne, intituled An Act for the better collecting Charity Money on Briefs by Letters Patent and preventing Abuses in relation to such Charities, Our Will and Pleasure is and We do hereby, for the bettcr advancement of These Our pious Intentions, require and command all Ministers, Teachers, and Preachers, Churchwardens and Chapelwardens, and the Collectors of this Brief, and all others concerned, that they and every of them observe the Directions in the said Act contained and $d o$ in all things conform themselves thereunto, and that when the printed Copies of these Presents shall lie tenderedun to you, the respective Ministers and Curates, Churchwardens and Chapelwardens, and to the respective Teachers and Preachers of every separate congregation, and to any Person who teaches or preaches in any Meeting of the People called Quakers, that you and every of you under the Penalties to he inflicted by the said Act do receive the same. And you the respective Ministers and Curates, 'Teachers and Preachers, and Persons called Quakers are, by all persuasive Motives and A rsuments, earnestly to exhort your respective congregations and Assemhlies to a liberal Contribution of their Charity for the relief of the said poor Sufferers. And you, the Churchwardens and Chapelwardens, together with the Ministers or some of the substantial Inhabitants of the several Parishes and Chapelries and all other places whatsoever within Our Counties Palatine of Lancaster and Chester, and Our Counties of York and I erky, are hereby required to go from House to House in the Week Days next following the publication of these Presents, to ask and receive of and from the Parishioners and Inhabitants and all other Persons their Christian and Charitable Contributions, and to take the Names in writing of such as shall contribute thereunto and the sum and sums by them respectively given and indorse the whole sums upon the said Printed Briefs in Words at length and subscribe the same with your ewn proper Hands, together with the Name of the Parish and Place where and the time when collected, and to enter tho same in the Public Bonks of Account kept for each Parish and Chapelry respectively, and the sum and sums collected together with the Printed Briefs so indorsed you are to deliver to the Deputies and Agents authorized to receive the same. Aud we do by these Presents nominate, constitute, and appoint Our beloved and faitliful Joseph Feilder aud Adam Cottam, Esquires, James Quartley, Henry Wiglesworth, Charles Wright and Robert Parkinson, clerks; 'Thomas Carr, Dixon Robinson and John Stevenson Salt, Gentlemen. Trustees and Receivers for the said poor Sufferers of the Charity to be collected by 
virtue of these Presents, with power to them or any Three or more of them to give Deputations to such Collectors as shall be chosen by the said poor Sufferers. And the said Trustees or any Three or more of them are to make and sign all necessary Orders for the due and regular Collection of this Brief and advancement of the said Charity, and to see that the Money when collected be paid to the said poor Sufferers. And lastly, Our Will and Pleasnre is that no Person or Persons shall receive the said Printed Briefs or monies collected thereon, but such only as shall be so deputed and made the Bearer and Bearers of these Presents and Dnplicates bereof. In Witness whereof $W_{\theta}$ have cansed these Onr Letters to be made Patent and to continue in force for One whole Year from Michaelmas Day next, and no longer.

Witness Ourself at Westminster, the twentieth Day of May, in the sixth year of Our Reign.

HUMPHREYS.

\section{APPENDIX B.}

"Sir William Bapastre held one carncate of land in Dolleworth by homage and the Rent of . . . . . ijs at Midsummer."-Inquis. 1311, Cheeth. Soc., Vol. 74.

"Gilbert de Sotheworth, in right of his wife, and Robert de Holande, bold a fourth part of one carve of land in Alston, in Socage, paying yearly at the four terms three shillings, and relief, etc.

"Thomas de Lathum holds a fourth part of the said carve, in Socage, paying yearly twelve pence, at the said terms, \&c."-Survey, 1320-46.

By an oversight which I greatly regret, I have omitted to mention in Chapter II that, the Rev. Timotby Smith, Curate of Longridge, was formerly Incumbent of Rainforth Chapel, near Prescott. In the Inquisition taken at Wigan, 1 June, 1650, there is the following reference to Timothy Smith:- "NIr. Timothy Smith doth now officiate as Ministr there, and is the present Incumbent there, and is an orthodox godly preaching Ministr, and came into the said place by the consent of the Chapellrie, and formerly received for his sallary The sume of forty pounds p. Ann, Allowed to the said Chappell out of the sequestrations." 


\section{GENERAL INDEX.}

Abram's, W. A., Notes on Townleys, 146,148

Admarsh Church, 63

Agreement of the People, 63

Agriculture, 121-125, 181, 185, 190, 191, $193,202,218,219,232,233$

Alston, area of, $2,6,122$; earliest mention of, 7 ; first lords of, 13 ; manor of, $13,15,31.121$; origin of name of, 2 ; population of, 131 ; select vestry of, 39,40

Alston-lane Church, 73, 77

Alton, 15

American war, 10

Amounderness, 6, 9, 11

Antiquities, 25, 152-155

Assheton's, N., Journal, 144, 145, 189

Ashes, 245

Authors, Local, 114, 115, 189, 243, 244

Bailey Chapel, 182, 183

Baines's Lancashive, 77, 119, 188; criticisin of, 16

Balderstone Church, 63

Ballads and Songs, 34, 114, 115, 24:

Barrow-upon-Soar, 73

Bateman's C.T.'1'. Notes, 175, 177

Beacou Fell, 47, 120, 220, 230

Bells at Longridge Church, 48, 49

Berry's charity, 127, 128

Berwick-upon-Tweed, 41

Blackburn Church, 63

Blackstone Edge, 23

Bobbin's Tin, Human Passions, 115

Book of Duys, 73

Botany of the clistrict, 259-271

Brabbin's school, 188

Bradley Hall, 189, 195

Brief, for fire at Dilwurth, 11, 272-274; for French Protestants, 179; for Great Farington, 179

Bright, John, a T'ory's opinion of, 96

Brock, river, 230

Brockholes Hall, higher, 215; lower, 215, 216
Bronghton, 23, 87

Buckley Delph, 149 ; hall, 149

Bull, White, at Ribchester, 159, 160

Bulsnape Hall, 245

Bunyan, John, 65

Burial customs (1690), 178

Calder, river, 23, 158, 183

Catholic Churches, 55, 73.76. 181-183, 199-201, 203-208, 236-240

Catholics, law against, 34, 39

Catterall, Manor of, 231

Cave, epitaph on one, 73 ; pedigree of, $73^{*}$

Celebrities, local, 99-115, 189, 207, 208, $241-214$

Chalgley, 31

Chantries, 48, 49, 160, 161, 234

Charities, the public, 125-131, 180, 182, 189

Charnock, Richard, 15

Chipping, area of, 187 ; church, 63,186 ,

191-19S; earliest mention of 186 ;

first lords of, 186; histary of, 187.

$159,192,197,198,202$; manor of,

$6,11,12,16,186,187,204$; origin of name of, 137 ; pupulation of, 189 ; vicars of, 226

Church rates, 180

Churchwardens, duties of, 41 ; female, 178

Churches and Chapels, Our Country, 58, $59,69,70,73,77-79,159,181,199$

Clerk, duties of, 179 ; salary of, 119.

Clitheroe Castle, 26, 116

College, St. John's, 216, 217 ; Alston, 217

Conformists, list of, 20

Conservative Clubs, 94-97

Co-operative Society, 88,89

Cottam Hall, family, and pedigree, 23, 140-14t

Cotton trade, 36, 41, 43, 46, 102-106, 158

County rouncils, 86,87

Cow-lill, 216 
Crimean IVar, 45

Cross, processional, 73,74

Crosses, old, $85,158,159,189$

Customs, old, 14, $15,57,120$

Darwen, river, 23

Dean House old chapel, 237

Death-rate, Longridge, 85

Dettingen, battle of, 180

Devil, the, at Hothersall, 138

Dewhurst, pedigree of, 151

Dilworth, area of, $2,10,122$; earliest mention of, 6; first lords of, ; manor of, $6,8,9$, I1, $13.17,19$; origin of name of, 2 ; population of, 131

Domesday hook, 6, 186, 230

Drunkenness, 88

Dun Caw Rib, 245

Dutch, "Victory" over the, 178

Dutton, area of, 158; hall and fawily, 145-143; manor of, 157

Edge Hill, battle of, 26,99

Elections, local board, $76,83,84$; political, 76

Elston, area of, 218 ; family and pedigree, 215 ; first lords of, 13 ; manor of, 13 ; origin of name of, 2

Etymology of place names, viii. 2, 120, $156,183,187,209,220,229,230$

Evesham, Abbot of, 207 ; Priory, 206, 207

Fair Oak, 189

Fumilic Lancastriensis, 146

Fell, Longridge, viii., 26, 31, 32, 116, $119,120,148,149$

Fishing in the lihble, 163, 183

Fishwick's Goosnargh, 64, 197, 220, 227, $220,234,245$

Flodden Field, battle of, 20

Floral Saciety, Longridere, 91

Foley's Collectanea S.J., 143, 182, 183, 203-206

Foxes, price of $(1680), 178$

Friendly Societies, $35,89-91$

Gambling, at Dutton Iee, 178 ; Gnosnargh, 145

Garstang Church, 63

Gentleman's Magazine, 192

Geology of the district, 247258

Giggleswick, 205

Gillow's Biblio Dict., 132, 135, 143, 150, 151, 203 ; Haydock Papers, 137, 237. 239
Gingle Hall, 245

Gladstone, a Tory's opinion of, 96

Goosuargh, agriculture of, 232-234: area of, 216 ; cakes and roads, 233, 234; church, 63, 224, 226, 234-235. earliest mention of, 231 ; first lords of, 231 ; manor of, $6,9,12,15,231$, 232,215 ; origin of name of, 5,229 , 230 ; population of, 236,240 ; vicars of, $223,235,239$

Green's History of England, 65

Gregson's Frogments, 23

Grimsargh, arriculture of, 218,219 ; area of, 218 ; church, 210-211; earliest mention of, 209 ; first lords of, 209 ; hall, 216 ; manor of, 209 ; origin of of name of, 202 ; population of, 218 ; vicars of, $210-214$

Gnild, Longridge, 31, 35, 40

"Harmonious Consent, the," 63

Harris Trustees, 57

Hayhursts of Duttor, family of, 177

Hermitage, the, 216, 217

Hesketh End, 188, 189, 201

Lane Chapel, 201

High House, 148, 149

Higher Core, 189

Hill Catholic Church, 236, 237

Hodder, River, 2, 23, 24, 33, 116, 117, $158,183,189$; Bridge, 24, 33 ; Mill, 32,33

Hoghton, Heights, 47 ; Manor of, 15 ; Tower, 113

Hospital, Goosuargh, 245

Hothersall, area of, 158 ; boggart, 138 . earliest mention of, 133 ; first lords of, 133 ; Hall, family of, 132, 138 ; Ifanor of, $6,7,9,10,12-15,19,132$; origin of naine of, 156 ; pedigree of, $134^{*}$

Hulme's 'Trustees, 55, 59, 60

Illegitimacy, 37, 38

Independent Churches, 56, 64, 78-81, 201,239

Inglewhite Lodge, 245

Iuglewhite fair, 246 ; Green, 245, 246

Inns, Longridgre, 87,88

Inquisitions, 49,162, I67, 192, 195, 220

Irich Church question, 93, 94

Jeffrey Hill, viii., 4, 45, 119, 120

Jerusalem, Prior of, 155, 231 
Jesus, Society of, 136, 141-143, 203, 205 . Collectanea, 143, 150, 151, 203, 205

Jubilee rejoicings, 46,47

Kay's Complcte History, 31

Kemple End, 26

King's Preachers, 51, 171, 173, 178, 197 . 228

Kirkham Church, 228; History of, 64

Knowle Green, 80

Knowsley, household at, 186

Lancushire, History of, 77, 119, 169, 188

Lancaster, Dukes of, 192 ; Prior of, 192

Landowners, 121, 158, 187, 218, 232

Leagram Hall and Weld family, 202-208

Lee, manor of, 15

Legends, local, 120, 121

Liberal Association, 93.98

Lisbon, earthquake at, 99

Liverpool, 40

Local board, 83.87 ; celebrities, 99-115 $139,140,241-244$; government, 35 , $36,82.87$

Longbridge, manor of, 21

Longridge, agriculture of, 122,123 ; area of, 2,122 ; battle of, 25 ; church, 24 , $26,48.73,178$; earliest mention of, viii., Fell, 26, 31, 32, 116, 119, 120, 148-150 ; guild, 34,35 ; manor of 30 ; origin of name of, viii., and Preston Railway, 42, 44, 100, 109, 113 ; polities of, $92-98$; population of, 43, 131; Vicar's of, 46, 54.56, $60-73$

Loud, River, 2, 189, 230

Loudscales, 246

Lune, River, 117

Lutterworth, manor of, 21

Michaelmas dues, 180

Middleton Hall, 245

Militia, history of, 31 ; quota for Alston,

Military, fund, 31 ; at Longridge, 45,46

MIurder at Longridge, 45

Newhouse Catholic Church, 237.240. cemetery, 239

Newlands, 189

Newsham, origin of name, 230

Newton-in-Bolland, 12

Nextros, Vicar of, 162

Non-jurors, 31, 189, 209, 210

Norse customs, 14,15

"Obstinates," 20
Old Church Clock, the, 66, 116, 117, 189

old bouses and old families, 132-151, $188,189,245$

Overcrowding question, 38

Palatine Note Book, The, 155, 175-177

Parlick Pike, 2, 47, 116, 117, 110, 120, 188

Patten Hall, 189

Pedigree of Cave-Browne-Cave, 73 . Cottam, of Knoll Hall, 144; Dewhirst, of Alston, 151 ; Hothersall, of Hothersall Hall, 136; Openshaw, of Bury, 140; Townley, of Dutton Hall, 146

Pendle Hill, 47, 120; history of, 120.

Physical history, 247-258

Pilgrimage of Grace, 47

Plants in the district, list of, 266-27

Political facts and figures, $92-98,105$

Population, 43, 131, 184, 189, 218, 220 245

Preachers, King's, 51, 171, 173, 178, 197, 228

Preston, affair at, 31 ; History of, 27 . its fair ladies, 31 ; and Longridge Railway, 42, 44, 100, 109, 113 ; vicars of, $126,209,214,228$

Prices, agriciltural, 123-125, 202

Primrose League, 97

Prince of Wales, marriage of, 45

Prospect, A, 117.119

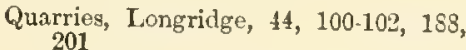

Railway, Preston and Longridge, 41-44 $100,109,113$

Rates, 38, 39, 52

Recusants, 23

Red Scar, 215

Ribble, river, 3, 5, 23-26, 39, 116-119, $138,152,158,159,163,183$

Ribbleton Mloor, 25

Ribchester, affair at, 26 ; agriculture of 175-177; area of, 158 ; church, 49. $52,63,157,160-181$; earliest mention of, 152; extracts from registers, $26,51,53,166,172,173$; first lords of, 157; manor of, $6,12-15,157$; origin of name of, 156 ; population of, 184 ; Roman remains at, 4,152 . $155,172,173$; "Twenty-four" of $53,172,175-187$; vicars of 50,52 $65,161-175,178-180$; workhouse, $130,131,160$ 
Roades of Heyhouse, family of, 149

Roman remains and roads, 3-5, 152-155, $186,208,230$

Sabbatarianism, 42

Sale Wheel, 158

Salesbury Hall, 26

Simlesbury, history of, 19,124 ; Vicar of, 126

Sanitary questions, 85,86

Savok, River, 23, 32

Scar'sdale, 119

Schools, 61, 75, 77, 73, 81, 107, 188, 221, 235

Singing in church, $57,59,75,77,78$

Social condition of people, $27,31,35,38$, $40,41,-43,49,50$; customs, 19,35 , $38,41,72$

Society, Co-operative, 88,89 ; Friendly, 89-91

Soldiers, nutster of, 31

Stanlawe, monks of, 156

Status de Blackburnshive, 161, 162, 186

Stocks, village, 41

Stone trade, $43,44,100-102,188$

Stonyhurst, 24, 33, 34, 115; Magazine, $29-31,33,120,207,208$

Stukeley's tour, 152, 172, 173

Stydd, Church, 157, 166-168; lord of manor of 167 ; origin of name of, 156 ; out-door service at, 167,168 ; Bishop l'etre, tomb at. 166 ; Catholic Church, 181, 182 ; priests at, 181 , 182 ; alms-houses at, 162

Surplice fees, 180

Surveys, Iancashire, 63, 162-167, 192-195

Taxes, ancient, 22
Tenlaes, the, 4, 119, 120

Thornley-cum-Wheatley, area of, 187 ; lords of, 186 ; manor of, 186, 187 ; origin of uame of, 187

Tithes, 60, 61, 163, 178, 180

Tootal Height, 44, 119-121

Townley's charity, 130, 131, 160 ; MISS., 14,15 ; family of, 145-148

Trade, cotton, 36, 41, 43, 46, 102-106, $158,220,246$; stone, $43,44,100-102$, 188

Traditions, local, 25, 28, 120, 121, 138, 200

Trials, 39

Twenty-four, of Goosnargh, 241; of Ribchester, 172, 173

Uniformity, Act of, $50,64,65$

Vandalism, 167, 183

Wesleyan Churches, 55, 80, 201, 241

Whalley Abbey, 161, 162; Church, 63 ; parish of, 168

Whinney Clough, 245

Whitechapel, earliest mention of, 220 ; church, 63, 220-228; bell, 220 ; origin of name, 220 ; population, 220 ; Vicars of, 220 ; dispute between parishioners and Rev. '1. Saul, 220238

Whitewell, 116

Whittingham Asylum, 244, 245 ; Hall, $24 \tilde{5}$

Wolfhouse, 188

Women's labour, price of, 124

Woodgates, 189

Written Stone, house, and lane, 4, 27, 30,14

\section{INDEX OF NAMES.}

Ablatt, Benjamin, 37 Adamson, William, 8.5

Almond, William, 35

Alston, liobert, 177

Tichard, 20

Althorpe, I ord, 35

A lveton, Richard de, 157

Ambrose, liev. Isaac, 61
Ambrose, William, 141

Anderton, Robert, 241

Anyon, Rev. John, 240

Archibald, Kev. Hugh, 79, 80

Ardern, John de, 133

Armetsdaile, IV. Rev., 195

Armitstead, Rev. E, 170

" William, 177 
Arrowsmith, Rev. R., 243

Ascroft, Alfred, 58

"Robert, 58, 109

, IVilliam, 83, 109

Ashton, Richard, 189, 202

Atherton, Mr., 14ã

Ashworth, Rev. Mr., 225

Atherton, Rev. T., 196

Atliason, Rev. John, 169, 171, 173, 174

" Rev. J. C., viii

" Myles, 152, 170

"T. A., 201

Ayrton, Kev. W., 170

Bailey, James, 84

," Thomas, 177

Baggs, Bishop, 151

Banks, George, 44, 11

"John, 84, 113

", Thomas, 42

", William, 40

Banastre, T., 9

Bannister, Rev. E. D., 221, 222

Barker, Rev. R., 240

Barluw, John, 17

Barry Joe, 34

Barton, Rev. William, 171

, Thomas de, 2.1

Baynes, William, 30

Bateman, Rev. J. T., 199

Beckwith, Miss, 72

Beesley, Rev. George, 241, 242

Bell, Fichard, 57

Benn, Rev. Thomas, 221

Bennett, John, 41 William, 41

Berliffe, John, 165 కั

Berry, James, 127, 128

Beesley, A., 52

Bickerstaffe, Colonel, 81, 121

Bibby, Walter, 108

Billington John, 52

Bilshorrow, Rev. John, 237, 238

, Richard, 30, 137, 177

Bindloss, Francis, 209, 215

Birl, Bishop, 171

John, 240

Birley, Rev. Webber, 68

Birkett, Rev. Mr., 221

Blackburn, Adam de, 157

John de, 157

Blackie, Professor, 280

Bleasdale, James, 137

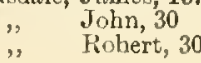

Blon, Rev. H. de, 199

Blundell, John, 137

Boardman, Rev. Charles, 15, 21, 73-76, 81,115

Boardman, W., 141

Bolton, Thumas, 165, 177, 191

," Robert, 195

Bond, Dr., 21

Rev. WVilliam, 168

IViliiam, 10

Booth, Robert, 57 Rev. William, 78,79

Botiller, John, 15, 16

, Richard, 12, 231

"Nicholas, 52

, William, 40, 52, 81, 84, 85, 145

Bräbin, John, 188

Bradley, Gilhert, 30

, John, 52

"Villian, 140

Bradyll, Mr., 145, 178

Breres, Edmund, 215

Brewer, Mr., 141

Bridge, Rev, J. B., 199

Brierley, Rev. Matthew, 236

Brinule, John, 158

Brockholes, Nicholas, 133

"Thomas, 206

,$\quad$ T. F., 238

$\because \quad$ iV. 10

Briscoe, Rev, H., 196

Bromlaw, liev. Robert, 168

Brooke, Mrs., 165

Browne, Rev. Henry, 73, 81

Buck, Charles, 52, 100

"Rev., 100

"William, 39, 40, 123

Burn, Rev. Mark, 170

Bushell, Willian, 231

" Rev. Williain, 234

Butterworth, Rev. Mr., 178

Byrne, Rev, Michael, 181

Bradshaw, Rev. IV. H., 237, 238

Bury, Rev. George, 240

Caldwell, Rev. G. A., 200

Campion, Kev. H., 142

Cardwell, Thomas, 189

Carlisle, Rev. John, 196

Carlisle, 'Thomas, 24, 25

Carr, Daniel, 45

Carroll, Rev. Thomas, 237, 238

Carter, Rev, Henry, 238, 239

" " James, 237, 238

, John, 237, 238

, John, 177, 179 
Catterall, Adam de, 231, 232

". Richard de, 231,232

$$
\text { "William, } 18
$$

Caton, Rev. Thomas, 77

Cave-Browne-Cave, Rev. F. A., 57, 59, $62,71,73$

Charnley, Alice, 210

"Am, 210

, Paul, 209

George, 52

Chatburne, Henry, 19

Richard, 19

Chester, Bishops of, $20,52,69,162,172$,

$176,178,193,195,224,227$

Chester, Earl of, 14

Chippendale, John de, 12

Chippen, Alexander de, 193

Richard de, 204

Clarke, Rev. F.. 200

" Miss, 72

Clärsson, Rev. lidward, 196

"John, 242, 243

" Rev. S., 73

", Tev. 196

Clayton, Rev, Leonard, 63, 64

" Ralph de, 157

Clifton, James, 1 .

Richard, 15, 16

". Pobert de, 16, 133

" Thomas de, 8

Villiam de 231

Clitheroe, Henry de, 157, 182

Clough, George, 36 Robert de, 182

William, 40

Coates, Ellen, $3:$

Cobham, J tord, 23, 142

Cackersand, Abbut of, 6,167

Coke, Richard, 15, 16

Colthirst, Abraham, 148

Conke, 'Thunas, 147

Cooke-Taylor, I. IV., 92

Cookson, Fichard, 223, 229, 230, 244

Copper and 'Tullis, $44,45,244$

Corbays, Jiev. William, 235

Corluridge, Janes, 125

, William, 99

Coseing, John, 209

Cottam, Mr., 34, 114, 140, 201

". Ermund, 14, 17, Is

". Elyes, 14

", Henry, 143

", Joln, 128, 143, 144, 162, 177

". lawrence, $16,17,18,31,141$ $143,114,177$
Cottam, Rev., 143

" Robert, 16, 17

", Thomas, 143, 144, 162, 177

" Rev., 141, 143

" Ughtred, 14, 16, 17, 18

,, William, 14

Cottom, Rev. Robert, 49, 61, 62

Coupe, Thomas, 88

Coventry, Rov. Ricbard, 168

Cowbar, Rev. Richard, 77

Cowell, Richard, 165

Cowper', Rev. Mr., 226

Cragge, Alice, 171

"John, 171

, William, 17

Cramond, Mr., 38

Cranborue, Viscount, 95, 97

Cressie, Robert, 171

Crombilholne, Rohert, 14, 16

" Rev. $16 s$

Cromwell, Oliver, viii., 24, 25, 159

Cross, John, 52

, Kev. John, 210

, William, 210, 215, 222-228

", Colonel, 210,215

Crossley, John, 78, 84, 85

Crumaleach, Henry, 210

Cumberland, Duke of, 99

Currer; Hugh, 194

Curtis, William, 30

Cutlow, Villiam, 30

Dagger, James, 85

Daniell, Robert, 30

," Thomas, 30, 177

Drvies, Rer. J, 5

"Rev. T. H., 213, 214

Dercon, Fredericl 54

Derby, liarls of, $21,26,52,81,148,149$, $183,186-188,199$

Dewhurst, Edward, 84

$$
\text { ," John, 162, 177, } 191
$$

," Rev. J., 201

"Mrs., 30

," Percival, 165

", Thomas, 165

William, 162

Dickson, liev. F. J., 167, 171, 175

"Joseph B., 121

Dilwortl, Bartholomew, 191

," James, 108, 109, 129, 192

," John, 17

," Osbert de, 13

"' Richard de, 11

Dimmore, Rev. L., 236 
INDEX OF NAMES.

Wixon, George, 87

" Richard, 40, 52, 69

" R. B., 112

William, 40

Dobson, James, 191

, Thomas, 191

" William, 157, 158, 201, 215

Doughtie, John, 186

M" Michael, 186, 187

Dre, Mr., 141

Drogo, Rev. -, 1 hs

Duckett, John, 31

Duckworth, James, 191 Thomas, 41

Dudeli, Thomas, 162

Dunkenhalgh. John de, 193

Dutton, Hugh de, 193

, William de, 145, 157

Eastham, Edward, 40

$$
\text { " John, } 99
$$

,'Thomas, 129

Eaves, William, 57

Eccles, Edmund, junr., 84, 109, 110

" $\quad$ " senr., 52, 109, 111, 148

"Fanny, 40, 41

George, 32

" H., 36

" Henry, 110

Richard, 5

Seth, 40,74, 127, 128

" Rev., 150, 151

'l'homas, 127, 128, 200

Ed̈mondson, Rev. C., 63

Elston," A nn, 215 Rev, R., 77

Richard, 209, 215

Eiliswick, John de, 14, 168

Ely, Dr., 142

Emmett, Mr., 32

Entwistle, Edward, 148

Errington, Archbishop, 151

Ethelston, Nicholas de, 13

," Roger de, 9, 13

" Thomas de" 14

Eton, William de, 9, 209

Farmer, Rev, John, 168

Farter, Rev, James, 221

Farrington, John de, 10

$$
\text { ", Thomas de, } 12
$$

Felgate, Rev. Thomas, 51, 62, 65

Fenton, James, 157, 158

Fielden, John C., 96
Filbie, Rev. William, 142

Finch, Richard, 85, 86

Fisber, John, 225

"Rev. James, 121, 170

"William, 85

, Rev. William, 99, 181

Fishowick, Richard, 209

B) Colonel, 64, 197, 220, 227, 229, 234,245

Fleet, Rev. Mr., 236

Fleming, Roger, 37

'I'homas, 44, 100-102, 111

tetcher, John, 44. 102, 111

Forbes, Archibald, 92

Foster, Charles, 40

Francis, Lev, 200

Fox, Mr., 6

Gale, Roger, 4

Gastrel, Bishop, 52, 176, 177, 220

George, Chevalier de St., 137, 238

Gerrard, Rev. Fr. 32

Gillow, Rev. Richard, 237, 240

" Richard, 132, 135, 137, 143, 150, $151,203,237-230$

Glasbrooke, Rev. Rogrer, 181

Glaxtow, Ellis, 30

Godfrey, Rev. Page, 170

Gordon, Rev. C. O., 97, 235

Goosnargh, Alexander de, 231

liobert, 231

Grafton, F. W. 94

Grainger, Rev. Richard, 210, 212

Greaves, Rev. H. T., 73

Gradwell Rev. R., 2, 3, 5, 280, 241, 242

Green, George, 137

, J. R., 6,65

Greenall, 'Thurstan, 40

Gregory, Charles, 194

," James, 107, 108

Gregson, 'Thomas, 30. 127

Griffith, Rev. John, 169, 171, 173

Gryse, Rev. I. J. de, 192, 200

Gunnow Miyles, 30

Hacket, lev. W., 240

Hall, John del, 186

Halsall, John, 100

'I'homas, 30

Hamilton, Duke of, 24

Hardwick, Charles, 3, 25, 27, 216

Hargreaves, George, 232

Hammond, Rr., 245

Rev. John, 240

Harland, John, 114 
Harris, Mr., 114

" Christopler, 193

" Mary, 193

" Rev, Robert, 211, 21 ?

Harrison, Dilworth, 76, 109

$$
\begin{array}{ll}
, & \text { George, 30 } \\
\text { ", } & \text { Rohn, 78, 137 } \\
\text {," } & \quad,, \text { Mrohn, 210, 211 }
\end{array}
$$$$
\text { " William, 211.213 }
$$

Hartington, Âarquis of, 94,107

Hartley, Beujamin, 45

$$
\text { " Jesse, } 101
$$

Rev, Mr , 61, G3, 164, 178

Haslewood, Rev. B. 'T., 70, 166, 169, 171,174

Haslewood, Rev. D., 174

Haworth, Jesse, 81

, Rev. Peter, 240

Haydock, Gilbert de, 12

$$
\begin{aligned}
& \text { "Rev. James, } 239 \\
& \text { "John de, } 231 \\
& \text { " Robert, } 134 \\
& \text { Hayes, Milia } \\
& \text { William, } 134 \\
& \text {," Rev. Bradley, } 177 \\
& \text { " Edward, 16 } \\
& \text { " Henry, 1ti } \\
& \text { " John, 162, } 177 \\
& \text { " Richard, 165, } 177 \\
& \text { Rev, William, } 80
\end{aligned}
$$

Hepay, Thomas, 18

Herford, Brooke, 169, 192

Hesketh, Gabriel, 130

$$
\text { , Peter, } 42
$$

$$
\text { ," Thomas de, } 231
$$

Heskin, Richard, 57

Henry, Dr., 4'

Hewitson, Anthony, 34, 57, 58, 69, 70 $73,78-80,159,181,19$

Hindle, Pev. Christopher, 50, 51, 63, ]64, 169

Hodgon, Captain, 24, 25

Hoshton, Adam de, 7-10, 157, 231

" Alexander de, 16

", I harles de, 30, 31, 118, 119 290

IFenry de, 11-16, 59, 66, 127,

Hoghton, Jolu de, 12, 133 Richard de, $6,12-14,17,18$ $133,134,143,145,157,160,161$

Hoghton, 'Thomas de, 13, 18, 19, 22

Holand, R. de, 9

Holden, Rev. Plilip, 149, 15̃0
Holden, Ralph, 150

Robert, 10, 191

Holmes, Rev. Peter, 237, 238

Holt, Mr., 167

Hoole, Henry, 35, 37, 111, 112

Hornby, Rev. IV. de, 168

Horrocks, Jacson \& Co., 105

Hothersall, Adam, 9, 10, 133

, Anne, 135

"Elizabeth, 135

" George, 134

, Grace, 134

,John, 20, 133-135, 147

Isabel, 135

, Margery, 135

, Nicholas, 133

Oliver, 40

13. Richard, 11, 15, 16, 133, 134,

Hothersall, Robert, 6, 9-11, 16, 133, 156

$$
\begin{aligned}
& \text { Roger, } 18 \text {. } \\
& \text { ", } \quad \text { Swanum, 134, 156 } \\
& 137,157
\end{aligned}
$$

Hothersall, Rev. Thos., 136

" Ughtred, 13, 134

" Warinus, 6,133

134,136

Willinm, $6,11,18,30,48,62$,

Hothersall, Rev. William, 136

Howarth, Riobert, 84, 85

Hull, B. de, 9

"Elizabeth, 210

,, Rev. J. W., 210, 212

Hummer, Robert, 209

Hurst, A., 9

" R., 7

Imbertus, Rev. -, 168

Ingham, Rev. Benjamin, 197

Rev. William, 50, 51, 63, 64, 169,172

Irvin, David, 54, 93, 94, 112

Ingleby, Catherine, $200^{\circ}$

, Margaret, 206

,. Thomas, 206

Jackson, R. R., 46

James I., 118, 119

Jenney, hev. Henry, 63

Johnson, Rev. Thomas, 169, 170, 179

Jones, Rev. J. B., 187, 196, 198

" H. B., 109

Jukes, James, 84, 87

Jump, John. 40, 84

Just, Rev. Mr., 4 
Kay, James, junr., 84

, and Pinder, 44,57

-Shuttleworth, James, 119

Ke'ighley, Thomas, 31

Kenyon, John, 44

Key, Joseph, 137

King, liev. Jobrı, 63, 64, 194, 195

" ". Thomas, 51

, F. C., 3, 217-271

Kington, Rev, T., 200

Kippax, Rev. Mr., 51

Kirby, James, 84

, Rev. Luke, 142

Ki'k, Edward, 130, 188, 189, 234, 243 244

Kirk, Henry, 243,

Knight, Rev. J. S. 199

Knoll, John de, 11

, Lawrence de, 12

" Fichard, 11

'Thomas de, 12

Knowles, T. R., 232

Lacye, Edmund de, 155

, Robert de, 155

" Roger de, 193

Lambert, IIajor-General, 25

Lancaster, Catherine, 135

IV., 52

Langdale, General, 24

Landreth, Mr., 155

Law, Edward, 39

Lawn, William, 42

Lawrence, 'Thomas, 16

Lawrenson, Rev. John, 199

Learoyde, Rev. R., 169

Lechonby, Anne, 135

." William, 136

Leigh, Dr., 123, 183, 245

Leland, 23, 123, 152, 183

Leicester, Earl of, 20

Lightfoot, John, 102 R. H. , 54, 103, 107, 108

Lincoln, Rev. John de, 168

Earl of, 119

Lind'ley, John, 187

Litelton, Thomas, 15

Livesey, George, 30

, Richard, 84, 85

William, 160

Long, Rev. Menry, 206

Longford, Nicholas de, 231

Lonrworth, J. H., 60, 61

Lowde, James, 191

Loyd, John, 30

Lund, James, 30

, IV., 52
Lynols, John, 17, 18

, Richard, 15, 16

, Robert, 147

William, 157

Lypton, Edward, 18

Mabun, IValter de, 134

AlcCoskery, Mrs, 109

McClane, fiev. T., 199

McKay, James, 120

MlcPhail, Duncan, 45, 46

Malley, John, $13 \tilde{3}$

Manchester, Bishop of, 55, 56

Marsden, J. N., 105

, Robert, 188

" Rev. Thomas, 105

"Rev. William, 105, 241, 242

111

William, 40, 83, 102, 105, 106,

Marsh, Rev. J. P., 237, 238, 240

" Rev. 'T., 242

Mártin, Baron, 46

, Rev. J. B., 236

", Rev. Thomas, 181, 182

Maude, Rev. Frederick, 57, 62, 68

Maudsley, Rev. Henry, 237, 238

Mercer, John, 121

Middlehurst, Rev. J., 199

"MLilid," Villiam, 18

Mill, J. S., 38

Nilner, George, 103

, liev. John, 196, 197

Iiobert, 103

Mírescogh, Lawrence de, 231

Iitchell, Isabella, 178

Montford, Simon de, 207

Mloore, Rev. William, 64

Moorliouse, Bishop, 56

More, Rev. John del, 168

Morron, Rev. E., 199

Mloss, Richard, 40

Iossop, Rev. Isaac, 25

Ioton, Adam, 19

Robert, 19

"Walter, 156, 157

,William, 145, 157

My'ton, Hugh de, 231

Iurphy, Rev. J. B., 200, 201

Iyres, John James, 211

Needliam, John, 15

Newsham, John de, 12

Newton, Rev. J. 199

Nichols, J. G, 192

Nock, Jolin, 148

Norcross, Rev. H., 169, 170

, James, 177 
Norcross, N., 52

Richard, 165

Norfolk, Duchess of, 157

Duke of, 114

Nuttall, David, 40, 52, 113, 125

O'Brien, Rev. W., 199

O'Connor, John, 95

Ogden, Rev. George, 65, 169, 170, 172, 173,179

Oliverson, Thomas, 232

Openshaw, Frederick, $95,121,132,140$, 158

Openshaw, Jonathan, 54, 55, 139, 181

Orrell, Hugh de, 12

Pedigree of, 139

" Rev. P., 200

Osbaldeston, Edward, 72

Osborne, Riev. James, 73

Owtram, Richard, 54

Park, W. P., 245

Parker, Edward, 103

, James, 191, 203

" J. B., 234

Yarkin, Rev. George, 62, 67, 68

Parkinson, Christopher, 188

, Henry, 40

", John, 135 119

Canon Richard, 66, 67, 116.

Parkinson, Fichard, 40, 84, 116, 119

,. Rev. Robert, 40, 51-53, 59, 60, 62, 66, 67, 125, 128

Paslew, John, 161

Patchett, Richard, 171

Pearce, Riev. 'T., 196

"' Thomas, 54

Peárson, Bishop, 52 " Rev. Mr., 187 189, 192, 197, "198, 20 "

Pedder, Richard, 245

Penketh, Mr., 114

$$
\text { , Rev. John, 203-206 }
$$

"Lev. Richard, 203

Penny, Rev. James, 196

Rev. John, 221

Perrin, Rev. F. E. 171, 174, 175

Perry Liev. S. J., 92

Peters, liev. T. A., 215, 216

Petre, Bishon, 166

Phipps, E. M.. 135

11. 1I, 125

Piğot, Riev. lidward, $57,62,69,110,112$

Pilling, Rev. W. 211, 212

Pinder, Fichard, 41

Plompton, lichard de, 12
Poitou, R. de 6

Pokelington, Rev. R. de, 168

Pomerton, Lawrence, 8

Poole, Rev. F., 199

$$
\text { Josiah, } 177
$$

Potter, Archbishop, 197

"Janes, 186

, J. G., 97

Poulton, J. L., 231

PoweI, Rev. Austin, 237, 238

" Pierce, 237, 238

Pownde, Thomas, 141

Pownel, Major, 24

Powtrell, Nicholas, 18

Prescot, MIr., 173

Preston, R. de, 10

"William de, 132

Prestwich, William, 110, 111

Price, Rev. G., 79

Pritt, Rë. F. 'D., 211, 213, 214

Proctor, Rev. C., 201

Pye, Jaines, 40, 52, 88

Quartley, Rev. James, 169, 171

Raby, James, 107

" Mary, 107

Rev. R., 199

Radcliffe, Edward, 145

" George, 30, 66, 145

". Henry, 145

", Rev. James, 221

", John, 14

", RaIph, 27-29, 144, 162, 177

, Richard, 52

", Robert, 14, 178, 179

," Thomas, 14, 28

"William, 28, 178,

Kaines, Rev. R., 48, 50, 52, 160, 161,!171 234

Rawcliffe, John, 159

Rawdon, Rev. J. H., 209

Rawsthom, Riev. W., 106

Rieade, George, 165

"James, 165

Reëre, Rev. John, 199

Relph, Rev. 1saac, 169, 171, 173, 180

Rhodes, Edward, 178

Ribchester, Christian de, 13

" Robert, 19

" William de, 19

Richards, F. C, 165

Richardson, Rev. L., 143

$$
\text { " IV., } 37
$$


INDEX OF NAMES.

Richmond, James, 191

Rigby, Thomas, 178

Rigmaden, Thomas de, 231

Rimmer, Rev. John, 181, 199

Roades, Frances, 128

John, 128, 149

Robinson, Richard, 57

, Rev. - 196, 198

Rochefort, H. de, 11

Roches, Emerie de, 192

Rock, Rev. Dr., 151

Rossa, Ralph de, 193

Rothwell, James, 148 Iarquess de, 148, 158

Rymer, Thomas, 81, 94, 158

, T. H., 94

Sagar, Edmund, 53

Samleshory, William de, 157

Sanderson, Rev. John, 150

$$
\text { ," ", Nicholas, } 150
$$

William, 150

Saul, Rev. Thomas, 221-228

Scott, Rev. Giles, 78, 80, 81

Searle, Hugh, 162

Seed, John, 40, 53, 177

") Robert, 147

'Thomas, 177, 178

Séfton, Mr., 180

Sharpe, Rev. John, 62, 66

Sharples, Bishop, 151

, Rev. Henry, 77

"James, 178

," Jeffrey, 165

, John, 44

Shawe, H., 30

$$
\text { Mir., } 189
$$

Shelley, Lady, 216

Sherbourne, Rev, Mr., 63, 220, 221

Sherburne, Anne, 206

, Edmund, 147

", Elizabetl, 206

", Isabel, 206

," John, 162, 163

MIr., 24

". Nicholas, 206, 207

P̈ichard, 22, 147, 157, 163 , 203-207

Sherburne, Robert, 207

Shilleto, Rev. William, 235

Shortt, Rev. Jonathan, 92, 153, 155

Shuttleworth, Rev. H., 225-228

$$
\text { ," Richard, 30, 40, } 111
$$

Singleton, Alan de, 6,8

", Cuthbert, 52, 130
Singleton, George, 128

, Henry, 17, 1

James, 17, 18

, John, 17, 44

", Nicholas de, 231

,, Fichard de, 231

Fobert de, 7, 1

, Ringer, 16

,' Thomas de, $7,8,22$

William de, 11, 231

Skilbeck, William, 40

Skilikorne, John, 15, 16

Slagg, John, 96

Slater, Ann, 136

, Gilbert, 210

, Thomas, 210

Slätter, Rev. P. G., 221

Slinger, Henry, 88

Sinith, Fanny, 99

, $\quad$ Frederick W., 95

,J John, 121, 245

Fiobert, 40, 44, 46, 54.57, 61,84

$85,89,95,106-108,121$

Smith, Rev. Timothy, 50, 51, 61, 63, 64

"' 'Tom C., 93, 9 1

William, 54, 57, 107

Suithson, M1ajor, 25

Sowerbutts, Arthur, 165

Eli, 96

". Robert, 177

Sonthward, Rev. Joshua, 239

Southworth, Joln, 20,22

spencer, J Thomas, 20

" Rev. John, 240

'Thomas, $40,44,102,111,120$

'Thomas de, 193

Stanley, Lord, 104, 105

, Thomas, 186

Stephensorr, Rev. 'T., 221, 227

Stevenson, WV. H., viii

Stuckdale, Rev. IV , 196

Stratford, William, 52

Straytburrell, Rev. James, 15

Strickland, William, 41

Studholme, Rev. R., 235

Stukely, Dr., 4, 152

Sudell, Mrs., 30 .

Sumner, Rev. R., 199

Swarbrick, Richard, 148

Swindlehurst, lid., 193

$$
\text { , lit., } 193
$$

'Thos., 193

"Isabella, 13

, Riev. IV , 168

Tarleton, Liev. James, 161

'T'aylor, Bartholomew, 138 
Taylor, Isaac, viii, 5, 187, 230

Thirelby, Rev. Thomas 168

Thirkyngham, Rev. L. de, 168

Thompson, Rev. James, 137

Thornber, Rev. W., 5

Thorpe, Thomas, 171

Threlfall, John, 136

Throup, Mary, 37

Tobin, George, 111

Tomlinson, Robert, 31

Tootel, Rev. Christopher, 206

Townley, Abraham, 148, 173

$$
\text { ", Bernard, 206 }
$$

Henry, 130, 146-148, 157, 177

Townley, John, 146, 147

Isabel, 206

", Katherine, 147

", Nicholas, 206

Ralph de, 14

i57 Richard de, 14, 15, 145.148,

Townley, Robert, 146

$$
\text { ", Roger de, } 13
$$

, Thomas, 146

Townson, Clement, 194

Trappes, Rev. F., 200

Travers, Willam, 134

Trimble, Dr., 86

Tullis, James, $74,84,112$

Tyldesley, Thurstan, 22

Tyrer, Rev. R. C., 201

Vavasour, Walter, 137, 138, 182

Waddington, W., 115

Wagstaffe, Rev. J., 181

Walkden, Rev. H., 204

Walker, Iev" Peter, 123, 124, 201, 202 "Mr.. 51

," William, 26, 63, 99

Wakefield, Rev. WV. de, 168

Wall, James, 134

William, Rev., 62

Walmsley, B., $54,96,113,114$

"Jobn, 30, 31

" Robert, 15, 16

", Thomas, 52

Walne, Ann, 45

William, 20

,. William 10

Walton, Rev. Thomas, 77

"James, 17, 18, 141

" Thomas, 141

Ward, Jobn, 175, 177
Waring, Heury, 46, 84, 94, 96

", Rev. H, 200

", William, 88

Warren, Mr Justice, 246

Waters, MIr., 114

Watkin, WV.'T.. 155

Watmongh, Rev. W. J., 201

Watson, Wdmnnd, 177

Grace, 113

Weld̈, Edward, 207

" George, 203

"Elizabeth, 206

"John, 120, 187, 202.208

"Thomas, 34, 202, 204

, Cardinal, 157

Verburton, G. de, 12

Wesley, Rev. John, 196, 197

Whalley, Abbot of, 161, 162, 187

"Dean of, 19

ton, John, 36

White, John, 52

" Rev. Mir., 51

", Rev. Richard, 68, 96

Whittaker, Iev. 'T. D., 26, 152, 156, $157,160,169,170,183$

Whittaker, John, 13, 14

Thomas, 54, 57, 121, 158

'Thomas, 16, 22

Whittle, Arthur, 8 '2. George, 60, 82, s8, 102.107, 111,

Whittle, James Pye, 54, 57, 84, 85, 94, 106

Whittle, Peter, 244

Wilcook, Rev. C., 236

Wilkinson, Rev. Edmund, 192, 196-198, 226,227

Willasey, John, 30, 177

Wilson, Thomas, 148

, Rev. 1lr., 226

, Nrs., 59

Winmarleigh, Lord, 105, 186

Winstanley, Edward, 135, 137

Wiseman, Cardinal, 151

Wodehouse, Rev. W. de, 168

Wolfytt, Rev. George, 169-171

WTood, Edmmind, 165

Woods, George, 45,46

"Thomas, 84

" William, 45

Wren, William, 171

Wright, Rev. B., 221

Wroe, Dr., 179 


\section{LIST OF SUBSCRIBERS.}

\section{LARGE PAPER COPIES.}

Subscribers marked * have also taken small copies.

Adamson, Mr. 1R., Market-place, Longridge

Adamson, Mr. W., Market-place, Longridge

Archibald, Rev. Hugh, College Villas, Longridge

Ascroft, A. E., Esq., Solicitor, Gleadale, Longridge

Arkwright, Mr. J., Bookseller, Lune-street, Preston

Bamber, Mr. John, Birtwistle-street, Accrington

Backhouse, Thomas J., Esq., Solicitor, York Cliff, Billington, Blackburn

Banks, MIr. George, King-stret, Longridge

Banks, Mr. Jehn, Strickland House, Iongridge

Barker, Mr. H., College Villas, Longridge

Beaver, Mr. John, Fishergate, Preston

Bell, Mr. Richard, Berry-lane, Longridge

Bell, Richard, Esq., Mrontague-street, Blackburm

Blackburn, Mr. T., Spade Mill, Longridge

Blackhurst, W., Esq., Sobicitor, Grimsargh

Bowdler, W. H., Esq., J.P., The Square, Kirkham

Bradley, Mrs., Berry-lane, Longridge

Bretherton, MIr. W., IVeavers' Arms, Longridge

Brindle, John, Esq., Ribblesdale House, Sonthport

Brown, R. C., Esq., M.D., J.P., Winckley Square, Presten

Viscount Cranborne, M P., Cranborne, Salisbury

The Right Hon. Viscount Cross, G.C.B., Eccle Riggs, Broughton-in-Furness

Cave-Browne-Cave, Rev. F. A., M.A., Vicarage, Longtidge (two copies)

Catterall, E., Esr., West Cliff, Preston

Clayton, Mrs., I'ishergate, Preston

Cooksey, G., Esq., L. D.S., Fishergate, Preston

Cooper, IV., Ksq., Solicitor, Lune-street, Preston

C'rossley, Mr. D., Chatburn-road, Longridge

Cressley, Mr. John, Berry-lane, Longridge

The Rt. Henble. the Earl of Derby, K.G., Knowsley, Prescot

Dewhurst, Mr. John, Mersey-street, Longividge 
Dickson, Alan C., Esq., Solicitor, Green Nook, Longridge

Dickson, George H., Esq., Solicitor, West Cliff, Preston

Dilworth, Thomas, Esq., The Asylum, Whittingham

Dixon, Mr. G., Clerk to the Guardians, Preston

Dryden, Mr. W., Barton-terrace, Preston

Duckworth, Mr. T., King-street, Longridge

Duckworth, Mr. H., Stone Bridge House, Longridge

Dugdale, Joseph, Esq., J.P., Blackburn

Earnshaw, Mr. John, Mersey-street, Longridge

Eccles, Edmund, Esq., \$I.R.C.S., Newtown, Longridge

Eccles, Mr. Thomas, Berry-lane, Longridge

Edelston, Thomas, Esq., Solicitor, Winckley-street, Preston

Emmett, Mr. James, Humber-street, Longridge

Escombe, Mr. William, Fishergate, Preston

Esplin, R. M. Esq., Hackness, Didsbury, Manchester

Fare, Mr. Cuthbert, Mersey-street, Longridge

Fielding, Mrs., Adelaide-terrace, Blacikburn

Finch, Richard, Esq., Solicitor, Park Crescent, Southport (two copies)

Garner, John, Esq., M.D., Winckley Square, Preston

"Gorham, J. J., Esq., M.A., M.D., Sion Hill, Garstang

Gradwell, Monsignor I., Very Rev., Cliughton-on-Brock

Greenhalgh, Mr. J., Pitt-street, Longridge

The Most Noble the Marquis of Hartington, M.P., Devonshire House, London

Hague, Mrs., Stanley-place, Preston

Hallmark, Alderman J. B., J.P., Fulwood, Preston

Hamilton, J. C., Esq., J.P., Stanley-terrace, Preston

Hesmondhalgh, Mr. E., Humber-street, Longridge

Heyworth, Eli, Esq., J.P., Blackburn

Hibbert, James, Esq., East View, Preston

Hollins, Frank, Esq., J.P., Greyfriars, Broughton, near Preston

Holt, Mr. R., Water-street, Ribchester

Hoole, Mr. H., 88, Oxford-street, Preston

Howorth, Mr. J. (Giluson and Howorth), Fishergate, Preston

Howarth, Mr. R. Dog Inn, Longridge

Irvin, Darid, Esq., J.P., Woodville, Longridge

"Jukes, George, Esq., M.D., Old Parsonage, Longridge

Jukes, James, Esq., Solicitor, Church-street, Longridge

Kay, Mr. R., Bookseller, Berry-line, Longridge

Kay, Mr. Thomas, Chapel Hill, Longridge

Keinp, Mr. W. H., Bookseller, Bury-road, Haslingden 
Lee, Sam., Esq., Clarendon-street, Preston

Lewis, Rev. IV., The Parsonage, St. Mary Cray, Kent

McCoskery, Mr. R., Market Place, Longrilge

Manchester Free Library 'per C. W. Sutton, Ker., Lilurarian)

Marsden, Mr. Walter, Market Plare, Longridge

Marsden, William, Esq., Market Place, Longridire

Marchington, T., Esq., Droylsden, near Manchester

Mears, Mr. T. (T. Mears and Co.), Fishergate, Preston

Martin, Rev. T., Stydu Lodye, Ribuhestur

Miles, Mr. J., Station Master, Preston

Myres, J. J., Esı., Winckley-street, Preston

Myres, 'T. H., Hsq., A.R.I.B.A., Winckley-street, Preston

Nigltingale, Rev. B., Stanley-place, Preston

Noble, Mr. Thomas, Poplar House, Lnngridge

Norwood, Mr. S., Fishergate, Preston (two copjes)

Nuttall, MIr. E., Chapel-walks, Preston

Openshaw, Frederick, Esq., J.P., Hothersall Hall, Ribchester

Openshaw, J. Hamilton, Esq., Stand Honse, Whitefield, near Manchester

Park, P. S., Esq., Gnildhall-wtreet, Preston

Parker, Mr. R., Severn-street, Longrilige

Parker, Mr. IV., Severn-street, Longridge

Patchett, Dr. W., Chipping

Patchett, Dr. R. A., Kibchester

Peters, hev. 'T. Abbott, M. A., St. John's College, Grimsargh (two copies)

Phipis, Miss E. M., Leckonby Cottage, Great Liccleston

Pinder, Mr. A., Mersey-street, Longridge

Pinder, Mr. Ir, Little-lane, Longridlete

Prestwich, Mr. N., Berry-lane, Lungridge

I'ritt, Rev. F. D., M.A., The Vicarage, Grimsargh

Pye, Mr. John, Bobbin T'urner, Ribchester (two cupies)

Pye, Mr. Thomas, Mill Honse Farm, Longridge

Iich, Mrs., Castle Hotel, Preston

* Robinson, Mr. H., Bookseller, Fishergate, Prestou

Rugurson, Mr. J., Alston Arms, Longrilge

lugrerson, Mr. W., Pitt-street, Longridge

Roper, Mr. J., Little-lane, Longridge

Rutter, Mir D., Grey Horse Hotel, P'resson

liyding. Mr. W., Comra-lane, Whitinglanı

Ryner, Thomas, Esq., Wilton Polyzon, Cleethan Ifill

lymer, T. HA, Esc., Higher Brourhton, Manchester

Savage, G., Fsq. (J. Thornley and Co.), Golden Teapot, Preston

Seward, J. A., Esog., rock Cuttage, Longridge 
Seed, Mr. E., Irwell-street, Longridge

Scott, Rev. Giles, Knowle Green, Ribchester

Sharples, Mr. G., Fishergate, Preston

Shuttleworth Kay-, R., Esq., Wood End, near Clitheroe

Smith, F. W., Esq., Dennisfield, Longridge

Smith, J. E., Esq., Kestor-lane, Longridge

Smith, Mr. Thomas, Chatburn-road, Longridge

Smith, W., senior, Esq., A jsley House, Longridge

Smith, W., junior, Esq., A psley House, Longridge

"Smith, W., Esq., East Cliff, Preston

Sotheran, H. and Co., Booksellers, Cross-street, Manchester (three copies)

Sowerbutts, H. E., Esq., J.P., Ribblesdale-place, Preston

Tangye, Richard, Esq., J.P., Cornwall Works, Birmingham

Teal, Mr. J., Bookseller, Southgate, Halifax

Threlfall, H. S, Esq., Solicitor, London-street, Southport

Tomlinson, Mr. J , Pitt-street, Longridge

Troop, Mr. John, Mersey-street, Longridge

Tullis, Alexander, Esq., Moor Park Avenue, Preston (three copies)

Tullis, James, Esq., Winckley-square, Preston (three copies)

Tullis, Mrs., Winckley-square, Preston

Tullis, Miss, Winckley-square, Preston

Tullis, W. T., Esq., Winckley-square, Preston (two copies)

Turner, slrs., Dixon's Farm, Grimsargh

*Walker, John, Esq., 282, Upper Brook-street, Manchester

Walker, Mr. W., Berry-lane, Longridge

* Walton, Rev. T., Alston-lane, Longridge

Waring, Mr. Henry, Chapel Hill, Longridge

Waring, Mr. John, Green Bank, Longridge

Watson, Mr. R., Mersey-street, Longridge

Weld, the late Jolnn, Esq,, J.P., I seagram Hall, Chipping

* Whitehead, Mr. C. W., Fishergate, Preston

"Whittle, James Pye, Esq., Alston Lodge, I.ongridge

Whittle, John H., Esq., Trigony, Closeburn, Dumfriesshire (two copies)

Whittle, Arthur, Esq., Maidwell, Draughton, Northampton

Whittle, Robert, Esq., Wolford Field, Shipston-on-Stour

Willacy, Mr. J., Lune-street, Longridge

Wilkinson, Mr. Isaac, Swarbricks' Arms, Longridge

Wilson, Mr. Janes, Bookseller, Stretfurd-road, Manchester (two copies)

*Winstanley, Miss, Chadswell, Chaigley

Woodhead, Mr. R., Hollin Hall Farm, Longridge

Woods, Mr. James, Pitt-street, Longridge

Woods, Mr. Thomas, Berry-lane, Longridge

Yates, Mr. Levi, Towneley Arms, Longridge 


\section{SMALL PAPER COPIES.}

Subscribers marked * have also taken large paper copies.

AIston, Mr. Thomas, Grimsargh Hall, (irimsargh

Amey, Mr. O., Bookseller, Friargate, Preston

Anderton, Wilfrid F., Est., J.1'., Haighton, near Preston

Ascroft, R. Lamb, Esq., Lytham

Astley, Rev. J. H., M.A., AIston College, Longrilge

Ashton, W. T., Esq., J.P., Darwen

Bailey, Mr. James, Market-place, Longridge

Bamber, Mr. John, Pitt street, Longriłge

Bamber, Mr. E., Pitt-street, Longrilge

Bannister, Rev. E. D., M.A., WhitechrpeI

Banks, MIr. 'Thomas, Grimsargh

Barnes, Mr. R., Plough Inn, Grimsaryh

Barron, Rev. T., Mixenden, Yorkshire

Beattie, Mr. A., Clapel-street, Preston

Bentley, Mr. T., Chapel-strect, Longridge (two coljies)

Beardsworth, Mr. W., Green-Iane, Longridge

Bennett, Mr. Joseph, Chatburn-road, Longrid ge

Bell, Mr. W., 45, Minto-street, Ashton-under Lyne

Berry, Mr. John, Sun Inn, Chipling

Bibby, Miss, Market-place, Longridge

Billington, Mr. Richard, Chatburn-road, Longridge

Boardman, Rev. Charles, D.D., St. Wilfril's, Longridge (ten copies)

Boltou Public Library (per Mr. J. K. Waite)

Bolton, Mr. Thomas, Ashley Tune-end, Whittingham

Bolton, Mr. W., Well-brow, Longridge

Bomont, Mr. C., Fishergate, Preston

Bond, Mr. Thomas, Pitt-street, Longridge

Bramwell, Mr. W., Timshell's Arms, Goosnargh

Bradshaw, Mr. J., Fisher's square, Longridge

Boune, Mr. William, Radcliffe Cottage, Langridge

Campbell, Mr. John, Chathurn-road, Longridge Carefoot, MIr. Thomas, Mersey-street, Longridge

Carr, Thomas H., Esq., West Cliff, Preston

Carter, MIr. James, Pitt-street, Iongrid st

Carter, Mr. Richard, Dunderdale-street, Longridge

CartmelI, Mr. H., Bookseller, Church-street, Preston

Catterall, Mr. E., High-street, Longridge

Clarkson, Mr. A., Berry-lane, Longridge

Clayton, Mr. Thomas, Mersey-street, Longridge

Cleg: Mr. James, Lune-street, I ongridge

Collinge, Mr. J., White Lion Farm, Longridge 
Cooke-Taylor, R. IV., Esq., Frenchwood, Preston

Cooper, Joseph, Esq., Sulicitor, Lune-street, Preston

Connor, W., P.S., Police Station, Ribchester

Cotton, Mr. Thomas, Market-place, Longridge

Counsel], Mr. J., Pitt-street, Longridge

Counsell, Mr. W., Mersey-street, Longridge

Coupe, Miss, Dilworth House, Longridge

Crook, Mr. E. S., Irwell-street, Longridge

Dagger, Mr. James, Berry-lane, Longridge

Dagger, Mr Thomas, Berry-lane, Longridge

Deane, Mr. A., Berry-lane, Longridge

Dewhurst, MIr. Joseph. Lune-street, Longridge

Dewhurst, Mr. George, Fishergate, Preston

Dewhurst, Mr. E., Pitt-street, Longridge

Dickson, Rev. F. J., M.A., The Rectory, Ribchester (three copies)

Dick, Mr. R., Ticknall, Derby

Dickinson, Mr. J., Little-lane, Longriage

Dilworth, Mr. John, Dilworth House Farm, Longridge

Dixon, E. L., Esq., M.D., J.P., Winckley-square, Preston

Dolphin, Mrs., Lune-street, Longridge

Dodgson, Mr. John, Little-lane, Longridge

Eastham, Mr. J., Crumpax Avenue, Longridge

Eccles, Mrs., Lune-street, Longridge

Edleston, Mr. H., Lune-street, Longridge

Ellis, Mr. F. W., Mersey-street, Longridge

Fishwick, Colonel H., F.S.A., The Heights, Rochdale

I letcher, Mr. Joseph, Thornley

Fletcher, Mr. L., Loftshay, Ribchester

Frazer, Mr. A. J., Fishergate, Preston

Garlick, E., Esq., J.P., Winckley-square, Preston

Gardner, Mr. James, Chatburn-road, Longridge

Gardner, Mr. W., Silver-street, Longridge

Gillow, Joseph, Esq., Bowdon, Cheshire

*Gorham, J. J., Esq., M. A., M.D., Sion Hill, Garstang

Gray, Mr. W., Mersey-street, Longridge

Greaves, Rev. H. T., M.A., Hodder-street, Longridge

Grcenall, Mr. James, Willow Cottage, Dutton

Greenall, Mr. Robert, Dutton

Greenwood, Mr. H., Chatburn-road, Longridge

Gregson, A. W., Esq., Chapel-street, Preston

Harrison, Mr. R. T., Little-lane, Longrilge

Harrison, Mr. J. Dilworth, Bnrnley 
Hayhnrst, Mr. J., Fishergate, Preston

Hawthornthwaite, Mr. J., Mersey-street, Longridge

Hague, Mr. C. 'T., Stanley-place, Preston

Halewood, Mr. W., Bookseller, Friargate, Preston

Heane, Mr. W., Bookseller, Fishergate, Preston

Helme, Mrs. Market-place, Longridge

Helme, Mr. Thomas, Lune-street, Longridge

Hesmondhalgh, Mr. J., Little lane, Lougridge

Hindle, Mr. W., Silver-street, Longridge

Historic Society of Lancashire and Cleshire (Per Mr. R. D. Radcliffe)

Hodkinson, Mrs., Pitt-street, Longridge

Hodson, Mr. J., Bull and Royal Hotel, Longridge

Hodson, Mr. 'T., Lune-street, Longridge

Holden, Mrs., Cnt Thorn, Longridge

Hogg, Mr. T., Chaddock-street, Preston

Howard, J. J., Esq., LL.D. (Harleian Society), Blackheath, Kent

Howell, Mr. E., Bookseller, Church-street, Liverpool

Hoyle, Mr. James, Chipping

James, Very Rev, Herbert A., D.D., The Deanery, St. Asaph

Isherwood, Mr. G., Skipton-road, Colne

Isherwood, Mr. W. T., Victoria Hotel, Preston

Jackson, Mrs., Mersey-street, Longridge

Jackson, Mr. John 'T., College Farm, Longridge

James, Mr. Richard, Chipping

Jamiesou, Mr. A., North-IVesteru Itotel, Preston

Jones, J. E., Esq., 113, Portland-street, Manchester

"Jukes, George, Esq., M. D., Old Parsonage, Longridge

Jump, Mr. T., Forty Acre Farm, Longridge

Kay, Mrs. Ann, Dog and Partridge Inn, Chipping

Kay, Mr. Abel, Mersey-street, Longridge

Kay, Mr. I'homas, Pitt-street, Longridge

Kay, Mr. William, Pitt-street, Longridge

Keighley, Mr. E., Mersey-street, Longridge

Keighley, Ar. J. Fox, Old Oak 1Lotel, Longridge

Kendall, MIr. J., Fulwood, Preston

Kenyon, Mr. John, Chipping

Lawson, Mr. J. (R. Lawson and Son), Fishergate, Preston

Lightfoot, Mrs., Ifollins 1 Iall, Longridge

Livesey, Mr. Richard, Alston Cottage, Longridge

Lloyd, Mr. J. W., Severn-street, Longridge

Lofthonse, Mr. S., Severn-street, Lougridge

Longworth, J. H., Esq., Chapel-street, Preston

Longworth, Mr. T., Bookseller, DIarket-place, Longridge

Longridge Co-operative Society 
Lord, Mr. J., Durham Ox Hotel, Longridge

McCoskery, Mr. J., Pitt-street, Longrilge McCreary, Mr. J., Green-lane, Longridge Mrkie, Mr. J., The Shaw, Longridge McKittrick, Mr. D., Golden-square, Preston MIcKittrick, MIr. F., Latham-street, Preston Marsh, Mr. W., Chatburn-road, Longridge Marsden, Mr. R., Mersey-street, Longridge Martin, Mr. T., Manor House Inn, Ribchester Mattliewson, Mr. J., Market-place, Longridge

MIayor, Mr. D., Grosvenor-place, Ashton

Miller, Mr. J., Adelphi-street, Preston

Nuttall, Mr. John, Nook Fold, Longridge

Oliver, T., Esq., M.D., Eldon-square, Newcastle-on.Tyne Oliver, J. S., Esq., Manchester and County Bank, Presto Ord, Mr. W. (Satterthwaite and Co.), Preston

Parker, Mr. J. T., Chatburn-road, Longridge Parker, Mr. J. WV., Talbot-street, Chipping

Parker, Mr. T., Fishergate, Preston

Parkinson, Mr. R., Bridge-street, Preston

Parr, Mr. Adam, Red Lion Hotel, Longridge

Pearson, Mr. J., Berry-lane, Iongridge

Penny, Mr. Thomas, Little-lane, Longridge

Pinder, Mr. J., Bay Horse Iın, libchester

Potts, Mr. R., Grimsargh

Preston, Mr. R., White Bull Iun, Tongridge

Prestwich, MIr. D., Fell Brow, Longridge

Prestwich, MIr. W., Berry-lane, Longridge

Proctor, Miss, Brow's Farm, Inngridge

Pye, Mr. James, Mersey street, Longridge

Pye, Mr. James, Pitt-street, Longridige

Rhodes, Mrs., Mersey-street, Iongridge

Ihodes, Mr. J., Chapel-street, Longridge

Rirby, Mr. W., The Birks, Thornley

Riley, Mr. J., Fulwood

* Liobinson, Mr. 1I., Bookseller, Fishergate, Preston

Lobinson, Mr. R., Chapel-hill, Longridge

looking, MIr. George, I Jee-street, Longridge

liochdale Free Libraly ( $\mathfrak{l}^{2} \mathrm{M}$ Mr. G. Hauson)

liyding, Mr. J., Comra-lane, Whittingham

liugerson, Mr. M., Talbot In1, Chipping 

The Right. Hon. Sir U. Kay-Shuttleworth, Bart., M.P., Gawthorpe, Padiham (two
copies)

Satterthwaite, J., Esq., J.P., Busliell-place, Preston

Sartin, Monsieur B., Reform Club, Preston

Seutt, Mr. John, Mersey Street, Longridge.

Sellers, Jonathan, Esq., J.P., Moor Park Avenue, Preston

Sellers, Mr. S., Berry-lane, Longridge

Seed, Mr. J., Green-lane, Longridg

Sharples, Mrs. Mary, Market-place, Longridge

Sharples, Mr. W., Crown Hotel, Longridge

Shortt, Rev. Jonathan, B.A., The Vicarage, Hoghton

Simpson, Mr. J., Derby-street, Preston

Shuttleworth, Miss M., Chatburn-road. Longridge

Singleton, Mr. J., Mersey-street, Longridge

Singleton, Mr. R., Mersey-street, Longridge

Skilbeck, Mr. G., Mersey-street, Longridge

Slater, Mr. H., Irwell-street, Longridge

Slater, Mr. T., Mersey-street, Longridge

Slater, Mr. H., Mlersey-street, Longridge

Smith, Mr. R., 1I, Ribble-place, Preston

Smith, P.C., Constabulary Office, Longridge

Smith, Mr. John, Berry-lane, Longridge

Smethurst, Mr. D., Little-lane, Longridge

"Smith, W., Esq., East Cliff, Preston

Southward, Mrs., Hodder-street, Longridge

Sowerbutts, Mr. T., White Bull Inn, Ribchester

Stevenson, Nr. A., Pitt-street, Longridge

Sudell, W., Esq., Holme Slack, Preston

Sumner, Mr. T. J., Lee-street, Longridge

Sumwer, Mr. E., Berry+lane, Longridge

Tindall, Mr. R., Berry-Iane, Longridge

Tindall, Mr. T., Co-operative Society, Ribchester

Thexton, Mr. T., Fishergate, Preston

Thompson, R. H. Esq., Wheatley Cottage, Longridge

Tipping, Mr. J., Lune-street, Longridge

Tullis, Mrs. J. A., Little-lane, Longridge

Turner, Mr. J., Mersey-street, Longridge

Williamson, J., Esq., M.P., Ryelands, Lancaster

Walker, Mr. J. R., Berry-lane, Longridge

* Valker, John, Esq., 242, Upper Brook-street, Manchester

Wahosley, Alderman B., Lord-street Mill, Preston

IValmsley, Mr. R., Lane-end, Longridge

Walnsley, Mr. John, Grapes Inn, Goosnargh

Wallbank, Mrs., Mersey-street, Longridge

Wallbank, Mr. R., Pearson's Farm, Longridge 
Wallace, Mr. J., Osbaldeston, near Fibchester

*Walton, Rev. T., Alston-lane, Longridge

Ward, Mr. John, Farmer, Longridge

Watson, Mrs., Berry-lane, Longridge

Wearden, Mr. James, Chatburn-road, Longridge

Weightman, Mlr. G., Mersey-street, Longridge

Welsby, Mr. J., Church-street, Ribchester

Whalley, Mr. John, Pitt-street, Isongridge

Wheeler, Miss, Berry-lane, Longridge

Whitehead, Mr. J., Fishergate, Preston

*Whitehead, Mr. C. W., Fishergate, Preston

Whiteside, Mr. J., Pitt-street, Longridge

*Whittle, James Pye, Esq., Alston Lodge, Longriclge (four copies

Whittle, Mr. Joash, Silver-street, Longridge

Whittle, M[r. J., Cut Tho'n, Longridge

Wilkinson, Mr. Isare, Pitt-street, Longridge

Wilkinson, Mr. J., Berry-lane, Longridge

Wilkinson, Mr. R, Preston Wives, Longridge

Wilkinson, Mr. W. J., Lee-street, Longridg*

Winckley, Mr. Henry, Thornley

*Winstanley, Miss, Chadswell, Chaigley

Worthington, Mr. T., Bookseller, Church-street, Preston

Wright, Miss, The Limes, Longridge

Yates, Mr. 'T. H., 6, Richmond terrace, Ripon-street, Preston 

UNIVERSITY OF CALIFORNIA LIBRARY

Los Angeles

This book is DUE on the last date stamped below. 
690 A history of

- I84S6 Longridge and district

*DA

690

L84S6 


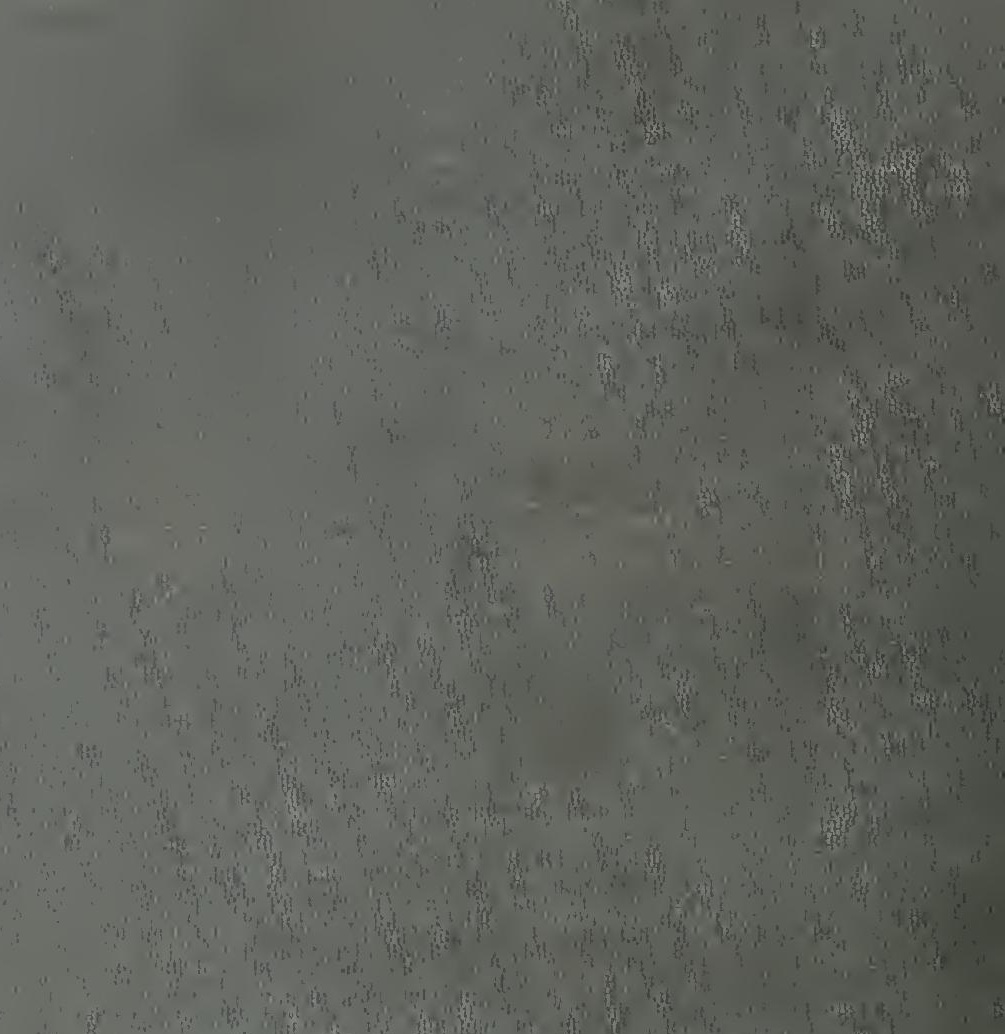

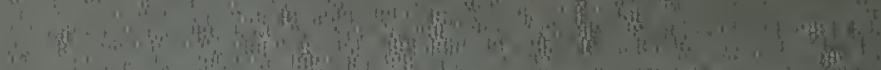

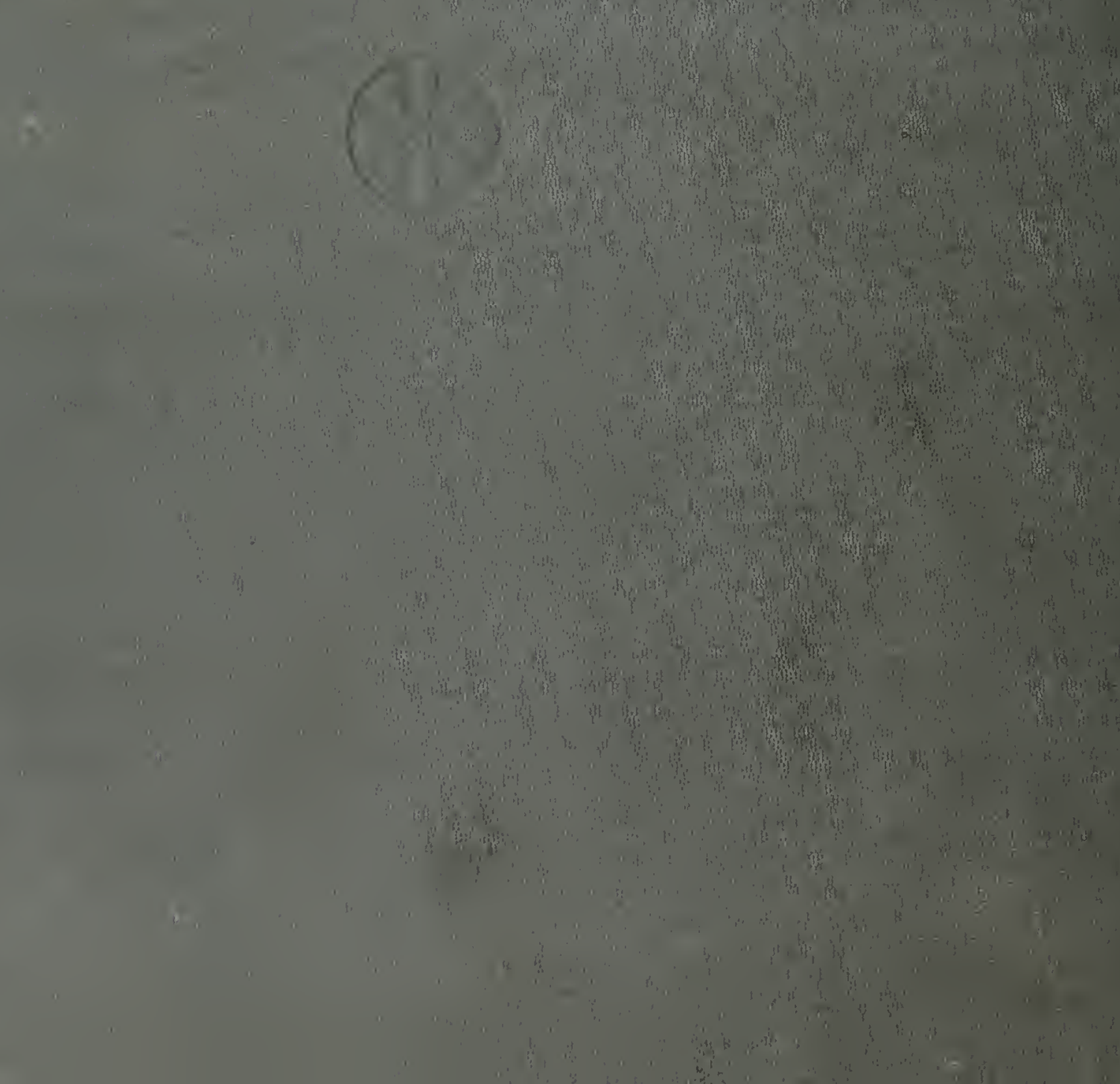

